VILNIAUS GEDIMINO TECHNIKOS UNIVERSITETAS

Vytenis SURBLYS

\title{
NELYGIA KELIO DANGA VAŽIUOJANČIO LENGVOJO AUTOMOBILIO PUSIAU AKTYVIOS PAKABOS VALDYMO ALGORITMAI
}

DAKTARO DISERTACIJA

TECHNOLOGIJOS MOKSLAI,

TRANSPORTO INŽINERIJA (T 003)

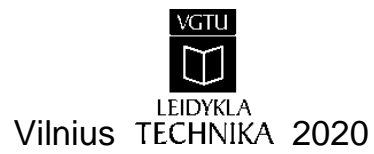


Disertacija rengta 2015-2020 metais Vilniaus Gedimino technikos universitete.

Vadovas

prof. dr. Edgar SOKOLOVSKIJ (Vilniaus Gedimino technikos universitetas, transporto inžinerija - T 003).

Vilniaus Gedimino technikos universiteto Transporto inžinerijos mokslo krypties disertacijos gynimo taryba:

\section{Pirmininkas}

prof. habil. dr. Marijonas BOGDEVIČIUS (Vilniaus Gedimino technikos universitetas, transporto inžinerija - T 003).

\section{Nariai:}

doc. dr. Algirdas JANULEVIČIUS (Vytauto Didžiojo universitetas, transporto inžinerija - T 003),

habil. dr. Dariusz MAZURKIEWICZ (Liublino technologijos universitetas, Lenkija, mechanikos inžinerija - T 009),

doc. dr. Robertas PEČELIŪNAS (Vilniaus Gedimino technikos universitetas, transporto inžinerija - T 003),

prof. habil. dr. Konstantinas PILECKAS (Vilniaus universitetas, matematika - N 001).

Disertacija bus ginama viešame Transporto inžinerijos mokslo krypties disertacijos gynimo tarybos posėdyje $2020 \mathrm{~m}$. birželio 19 d. 9 val. Vilniaus Gedimino technikos universiteto senato posèdžių salëje.

Adresas: Sauletekio al. 11, LT-10223 Vilnius, Lietuva.

Tel.: (8 5) 274 4956; faksas (8 5) 270 0112; el. paštas doktor@vgtu.lt

Pranešimai apie numatomą ginti disertaciją išsiųsti 2020 m. gegužès $18 \mathrm{~d}$.

Disertaciją galima peržiūrèti VGTU talpykloje http://dspace.vgtu.lt, Vilniaus Gedimino technikos universiteto (Saulètekio al. 14, LT-10223 Vilnius, Lietuva), Klaipėdos universiteto (H. Manto g. 84 K5, LT-92294 Klaipeda, Lietuva), Vytauto Didžiojo universiteto (K. Donelaičio g. 52-215 kab., LT-44244 Kaunas, Lietuva), Kauno technologijos universiteto (K. Donelaičio g. 20, LT-44239 Kaunas, Lietuva) bibliotekose.

VGTU leidyklos TECHNIKA 2020-003-M mokslo literatūros knyga

http://leidykla.vgtu.lt

(C) VGTU leidykla TECHNIKA, 2020

(C) Vytenis Surblys, 2020

vytenis.surblys@vgtu.lt 
VILNIUS GEDIMINAS TECHNICAL UNIVERSITY

Vytenis SURBLYS

\section{SEMI-ACTIVE SUSPENSION CONTROL ALGORITHMS OF A CAR MOVING ON ROUGH ROAD PAVEMENT}

DOCTORAL DISSERTATION

TECHNOLOGICAL SCIENCES,

TRANSPORT ENGINEERING (T 003)

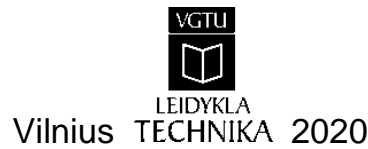


Doctoral dissertation was prepared at Vilnius Gediminas Technical University in 2015-2020.

\section{Supervisor}

Prof. Dr Edgar SOKOLOVSKIJ (Vilnius Gediminas Technical University,

Transport Engineering - T 003).

The Dissertation Defence Council of Transport Engineering of Vilnius Gediminas Technical University:

\section{Chairman}

Prof. Dr Habil. Marijonas BOGDEVIČIUS (Vilnius Gediminas Technical University, Transport Engineering - T 003).

\section{Members:}

Assoc. Prof. Dr Algirdas JANULEVIČIUS (Vytautas Magnus University, Transport Engineering - T 003),

Habil. Dr Dariusz MAZURKIEWICZ (Lublin University of Technology, Poland, Mechanical Engineering - T 009),

Assoc. Prof. Dr Robertas PEČELIŪNAS (Vilnius Gediminas Technical University, Transport Engineering - T 003),

Prof. Dr Habil. Konstantinas PILECKAS (Vilnius University, Mathematics N 001).

The dissertation will be defended at the public meeting of the Dissertation Defence Council of Transport Engineering in the Senate Hall of Vilnius Gediminas Technical University at 9 a. m. on 19 June 2020.

Address: Sauletekio al. 11, LT-10223 Vilnius, Lithuania.

Tel.: +370 5274 4956; fax +370 5270 0112; e-mail: doktor@vgtu.lt

A notification on the intend defending of the dissertation was send on 18 May 2020.

A copy of the doctoral dissertation is available for review at VGTU repository http://dspace.vgtu.lt, at the library of Vilnius Gediminas Technical University (Sauletekio al. 14, LT-10223 Vilnius, Lithuania), at the library of Klaipeda University (H. Manto st. 84 K5, LT-92294 Klaipeda, Lithuania), at the library of Vytautas Magnus University (K. Donelaičio st. 52-215 rm., LT-44244 Kaunas, Lithuania) and at the library of Kaunas University of Technology (K. Donelaičio st. 20, LT-44239 Kaunas, Lithuania). 


\section{Reziumè}

Disertacijoje nagrinèjamos elektroniniu būdu reguliuojamos lengvujų automobilių pakabos. Automobiliuose dažniausiai naudojamos pasyvios pakabos, kurios turi gamintojo nustatytas pastovias slopinimo charakteristikas. Tačiau sparčiai tobulèjant elektroninių sistemų valdymo technologijoms, ị automobilius vis dažniau montuojami pakabos slopinimo elementai, kuriais galima keisti slopinimo charakteristikas. Pagrindinis tokių sistemų trūkumas paaiškẻja automobiliui užvažiavus ant didesnių kelio nelygumų. Kadangi amortizatorius yra elektroninè sistema, turi veikimo uždelsimą, tad pageidaujamos slopinimo reikšmès pakeičiamos per vẻlai.

Disertaciją sudaro įvadas, trys skyriai, bendrosios išvados, naudotos literatūros ir autoriaus publikacijų disertacijos tema sąrašai bei penki priedai.

Ivadinejje dalyje nagrinejjama tiriamoji problema ir darbo aktualumas. Aprašomas tyrimų objektas, suformuluojamas tikslas ir darbo uždaviniai, pristatoma tyrimų metodika, darbo mokslinis naujumas, rezultatų praktinè reikšmė ir ginamieji teiginiai. Ivado pabaigoje pateikiamos disertacijos tema autoriaus paskelbtos publikacijos, pranešimai mokslinèse konferencijose ir seminaruose bei disertacijos struktūra.

Pirmajame skyriuje apžvelgiama mokslinè literatūra disertacijos tema. Pateikiama mokslinių tyrimų su lengvụjų automobilių pakabomis analizè, taip pat naudojamų pakabų valdymo principų apžvalga. Aptariami kelio paviršiaus nelygumų nustatymo būdai, atliekama virpesių, veikiančių vairuotoją, keleivius ir automobilio elementus, analizè.

Antrajame skyriuje pristatomas automobilio su sumontuotu lazeriniu atstumo jutikliu matematinis modelis, modelio patikrinimas. Aprašomas sukurtas kẻbulo svyravimų kompensavimo modelis ir elektroniniu būdu valdomos pakabos algoritmas. Pateikiami rezultatai gauti atliekant tyrimus su pasyvia ir pusiau aktyvia pakabomis.

Trečiajame skyriuje pateikta eksperimentinių tyrimų metodika ir naudota ịranga. Pristatomi lazerinio jutiklio optimalios montavimo vietos ir padèties paieškos eksperimentiniai tyrimai, jų rezultatai. Pateikiami automobilio amortizuotos masės svyravimų kompensavimo modelio ir sukurto pakabos valdymo algoritmo eksperimentiniai tyrimai.

Disertacijos tema paskelbti aštuoni moksliniai straipsniai: trys mokslo žurnaluose ịtrauktuose ị Clarivate Analytics Web of Science duomenų bazę, penki kituose recenzuojamuose žurnaluose. Disertacijos tema skaityti keturi pranešimai mokslinėse konferencijose. 


\section{Abstract}

The dissertation investigates the electronically adjustable car suspension. In cars, the most widely used passive suspensions have the manufacturer's fixed damping characteristics. However, the fast development of electronic control systems technology, the cars are increasingly fitted damping elements with the ability to change the damping characteristics. The main drawback of such systems is when the car comes on a high road bump. Since shock absorbers, like other electronic systems, have a time delay in operation, the desired damping values are changed too late.

The thesis includes introduction, three chapters, general conclusions, the list of references, the list of publications of the author on the subject of the thesis and five annexes.

In the introduction chapter reviews the research problem and the relevance of the thesis. The object of research and the aim of the thesis are described; the tasks of the thesis are formulated; the research methods, the scientific novelty of the thesis, the practical significance of the achieved results and the defended statments are described. The introduction is finished with author's publications concerning investigated topic, presentations at conferences and seminars and the structure of the thesis are provided.

Sources of scientific literature on the subject of the thesis are reviewed in the first chapter. An analysis of suspension used in passenger cars, as well as an overview of the principles of suspension control are presented. Methods for road surface irregularities identification are reviewed; vibrations that affect driver, passengers and car elements are analyzed.

The second chapter presents the mathematical car model with mounted laser distance sensor, also model validation is performed. The developed model of compensation of body oscillations and the algorithm of electronically controlled suspension are described. The results are compared with passive and semi-active suspension.

The methods of experimental research and used equipment are presented in the chapter three. Experimental tests of laser sensor optimal mounting location and their results are presented. Experimental research of sprung mass oscillations compensation model and the developed suspension control algorithm are presented as well.

Eight scientific papers on the subject of the thesis have been published: three publications have been included in the Clarivate Analytics Web of Science journals, five - were published in other peer-reviewed journals. Four reports on the subject of the thesis have been presented at scientific conferences. 


\section{Žymèjimai}

\section{Simboliai}

$b$ - ratų baze;

$c$ - pasipriešinimo koeficientas;

$f$ - priekinè ašis;

$F_{d}$ - amortizatoriaus slopinimo jèga;

$F_{k}$ - spyruoklès standumo jèga;

$\varphi, \dot{\varphi}, \ddot{\varphi}$ - sukimosi apie skersinę ašį kampas, kampinis greitis, kampinis pagreitis;

$k$ - standumo koeficientas;

$m$ - neamortizuotoji masè;

$M$ - amortizuotoji masè (pusès automobilio);

$r$-galinè ašis;

$t$ - laikas;

$v$-greitis;

$Z, \dot{Z}, \ddot{Z}$ - poslinkis, greitis, pagreitis;

$z_{l}$ - lazerinio jutiklio signalas;

$\Delta z_{t}, \Delta \dot{z}_{t}-$ padangos eigos poslinkis, greitis;

$\Delta z, \Delta \dot{Z}-$ pakabos eigos poslinkis, greitis;

$\delta$ - logaritminis dekrementas. 


\section{Santrumpos}

ADD - pakabos amortizatoriaus pagreičiu valdymo principas (angl. acceleration driven damper control);

CDC - amortizatorių tipas su nepertraukiamu slopinimo valdymu (angl. continuous damping control);

DOF - laisvès laipsnis (angl. degree of freedom);

$\mathrm{EH}$ - elektrohidraulinis slopintuvas (angl. electrohydraulic damper);

ER - elektrorheologinis skystis (angl. the electrorheological fluid);

HIL - realiu laiku uždara sistema atliekamų skaičiavimų įrenginys (angl. hardware in the loop);

IMU - inercinis matavimo įrenginys (angl. inertial measurement units);

IRI - tarptautinis kelio nelygumo indeksas (angl. international roughness index);

MR - magnetorheologinis skystis (angl. the magnetorheological fluid);

PDD - pakabos amortizatoriaus jègos valdymo principas (angl. power driven damper control);

PTU - Poznanės technologijos universitetas (Lenkija) (lenk. Politechnika Poznańska);

RMS - vidutinis kvadratinis nuokrypis (angl. root mean square);

RMSE - vidutinè kvadratinè paklaida (angl. root mean square error);

SSE - liekamujų paklaidų kvadratų suma (angl. sum of squares error);

VDV - virpesių dalies vertè (angl. vibration dose value);

VGTU - Vilniaus Gedimino technikos universitetas.

\section{Sąvokos}

Matematinis modelis - automobilio judejjimo dinamiką atitinkanti fizinè sistema, aprašyta matematine kalba.

Nelygi kelio danga - asfalto danga su paviršiaus vertikalia nelygumo kliūtimi.

Pakaba (angl. suspension) - transporto priemonès mechanizmai ir tamprieji elementai, jungiantys atramines dalis (ratus) su rèmu arba laikančiuoju kèbulu.

Pasyvi pakaba (angl. passive suspension) - papildomais energijos šaltiniais nereguliuojama automobilio pakaba.

Pusiau aktyvi pakaba (angl. semi-active suspension) - pakaba turinti kintamo slopinimo elektriniais signalais valdomus elementus.

Svyravimai - pasikartojantis tam tikros vertės kitimas laike. 


\section{Turinys}

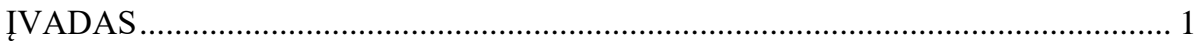

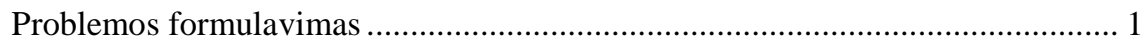

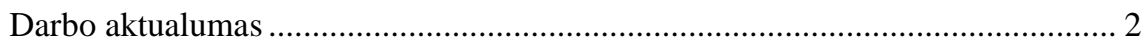

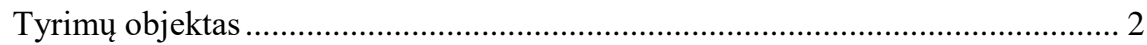

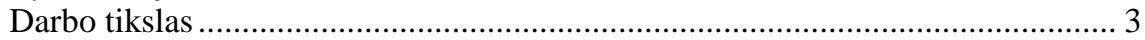

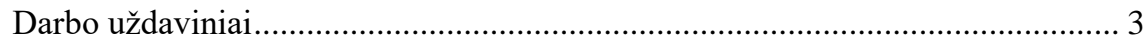

Tyrimų metodika …….......................................................................... 3

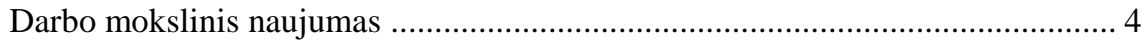

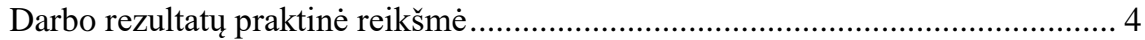

Ginamieji teiginiai ……............................................................................ 5

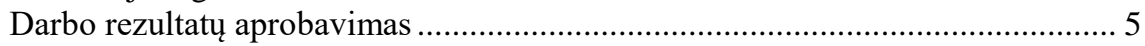

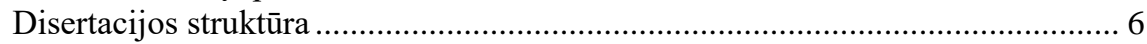

1. LENGVOJO AUTOMOBILIO SU PUSIAU AKTYVIA PAKABA VALDYMO ALGORITMŲ APŽVALGA ………........................................................ 7

1.1. Lengvuosiuose automobiliuose naudojamų pakabų analizè .......................... 8

1.2. Pusiau aktyvios pakabos valdymo principu analizè..................................... 15

1.3. Pakabos valdymo principas su kelio paviršiaus nelygumų nustatymu.......... 21

1.4. Kelio paviršiaus nelygumų nustatymo būdų apžvalga ................................. 22

1.5. Kelio nelygumų nustatymo metodai .......................................................... 23

1.5.1. Japonijoje naudojamas nustatymo metodas ...................................... 23

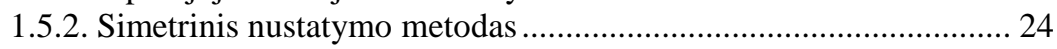

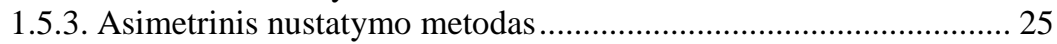


1.6. Moksliniuose darbuose naudojamų matematinių modelių apžvalga ir

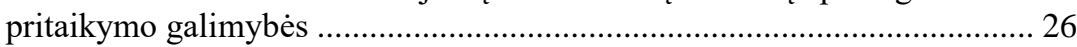

1.7. Automobili veikiantys virpesiai ir jų nustatymo būdai ................................ 27

1.8. Tarptautinis kelio nelygumo indeksas ........................................................ 29

1.9. Teorinių ir eksperimentinių tyrimų prielaidos .............................................. 30

1.10. Pirmojo skyriaus išvados ir disertacijos uždavinių formulavimas .............. 31

2. LENGVOJO AUTOMOBILIO SU PUSIAU AKTYVIA PAKABA IR KELIO NELYGUMŲ NUSTATYMO SISTEMA DINAMINIŲ SAVYBIŲ SKAITINE ANALIZE்

2.1. Automobilio su sumontuotu lazeriniu atstumo jutikliu matematinis

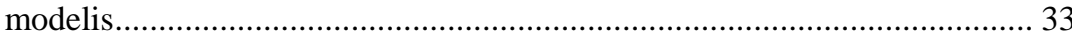

2.2. Standumo ir slopinimo elementų charakteristikų netiesiškumas .................. 37

2.3. Amortizatorių suveikimo uždelsimas ...................................................... 42

2.4. Pavieniai ir ištisiniai kelio paviršiaus nelygumai .......................................... 43

2.5. Matematinio pusės automobilio su sumontuotu lazeriniu atstumo jutikliu

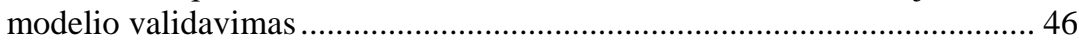

2.6. Automobilio, važiuojančio per kelio nelygumus, su skirtingomis amortizatoriaus slopinimo savybèmis analizè............................................. 48

2.7. Pasyvios ir pusiau aktyvios pakabos, valdomos „Skyhook“ principu,

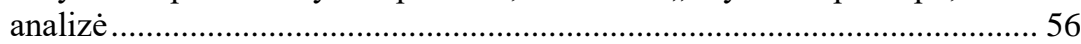

2.8. Automobilio amortizuotos masès svyravimų kompensavimas ..................... 58

2.8.1. Amortizuotos masès vertikalaus poslinkio svorio centro taške kompensavimas .......................................................................... 59

2.8.2. Amortizuotos masès sukimosi apie skersinę aši kompensavimas.. 59

2.8.3. Lazerinio jutiklio montavimo padèties kompensavimas .................. 60

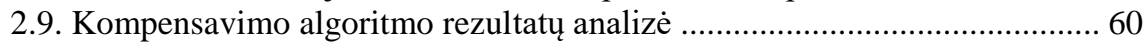

2.10. Pusiau aktyvios pakabos su nelygumų nustatymu valdymo principu

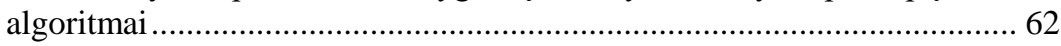

2.10.1. Amortizatorių pasipriešinimo jègų parinkimo algoritmas pagal nustatytų nelygumų aukšsti

2.10.2. Amortizatorių pasipriešinimo jëgų parinkimo algoritmas pagal

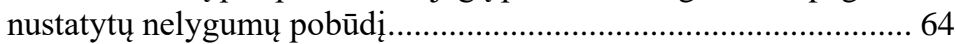

2.10.3. Amortizatorių pasipriešinimo jègų parinkimo algoritmas pagal maksimalų nelygumo aukštị ir pobūdị, atsižvelgiant $\mathfrak{i}$

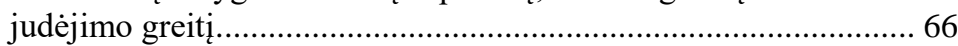

2.11. Pusiau aktyvios pakabos valdymo principų rezultatų analizè ..................... 67

2.12. Valdymo principu apibendrinimas.......................................................... 74

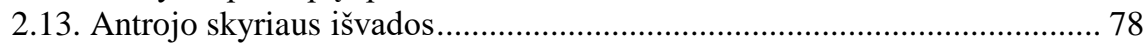

\section{AUTOMOBILIO SU PUSIAU AKTYVIA PAKABA EKSPERIMENTINIAI}

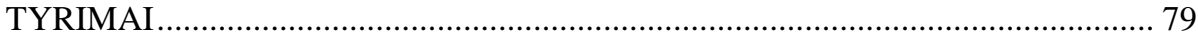

3.1. Eksperimentinių tyrimų metodika................................................................ 79

3.2. Automobilio dinaminių parametrų matavimo įranga .................................... 82

3.3. Eksperimentinių duomenų apdorojimas...................................................... 86

3.4. Kelio nelygumų nustatymo metodų eksperimentiniai tyrimai ...................... 87 
3.5. Pusès sinusoidès formos nelygumas eksperimentiniuose tyrimuose 90

3.6. Lazerinio atstumo jutiklio montavimo vietos nustatymo eksperimentiniai tyrimai.....

3.7. Kompensavimo algoritmo eksperimentinių tyrimų rezultatų analizè .......... 93

3.8. Pusiau aktyvios pakabos su nelygumų nustatymu eksperimentinių tyrimų rezultatų analizè

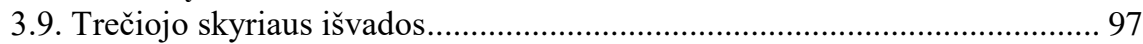

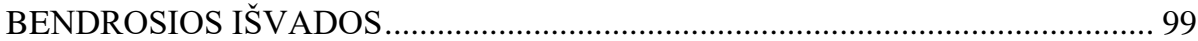

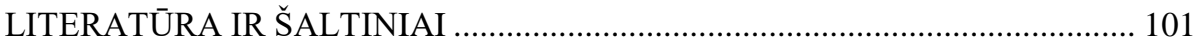

AUTORIAUS MOKSLINIŲ PUBLIKACIJŲ DISERTACIJOS TEMA SĄRAŠAS

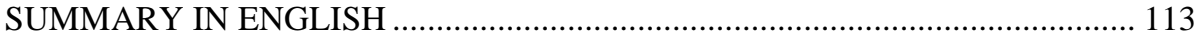

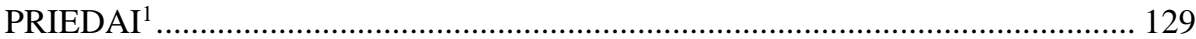

A priedas. Programinio paketo Matlab kodas pradinių pusès automobilio modelio duomenu ivesčiai .......................................................... 131

B priedas. Eksperimentiniuose tyrimuose naudotų jutiklių specifikacija ......... 133

C priedas. Disertacijos autoriaus sąžiningumo deklaracija .................................. 137

D priedas. Bendraautorių sutikimai teikti publikacijose skelbtą medžiagą

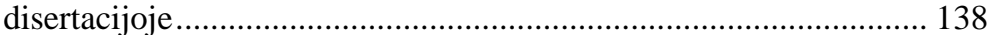

E priedas. Autoriaus mokslinių publikacijų disertacijos tema kopijos .............. 147

${ }^{1}$ Priedai pateikiami pridètoje kompaktinèje plokštelèje. 

INTRODUCTION

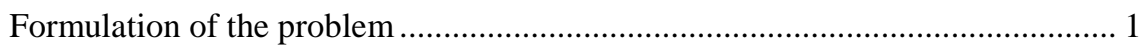

Relevance of the thesis ................................................................................... 2

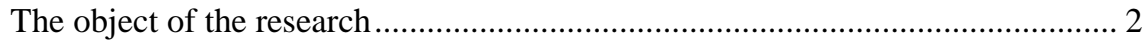

The aim of the thesis ........................................................................................ 3

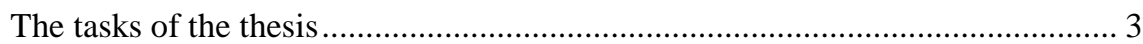

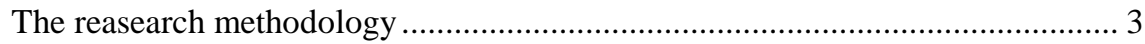

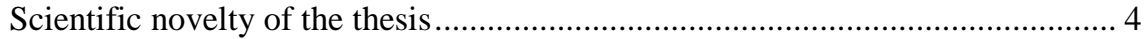

Practical value of the research findings .............................................................. 4

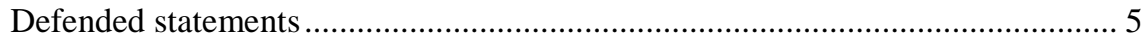

Approval of the research findings.................................................................... 5

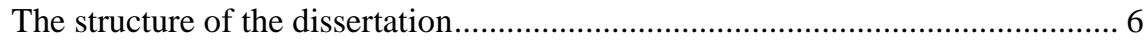

1. REVIEW OF A CAR WITH SEMI-ACTIVE SUSPENSION CONTROL

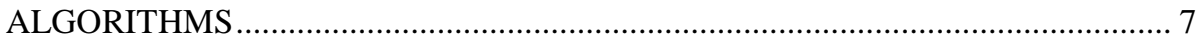

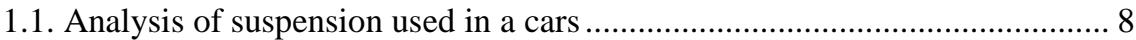

1.2. Analysis of the principles of semi-active suspension controls.................... 15

1.3. Analysis of suspension control with road surface roughness identification

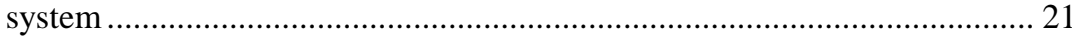

1.4. Overview of road surface roughness identification methods ........................ 22

1.5. Methods for identification road roughness …………................................... 23

1.5.1. Identification method used in Japan ............................................. 23

1.5.2. Symmetric method of identification ............................................. 24 
1.5.3. Asymmetric method of identification

1.6. Overview of mathematical models used in scientific works and

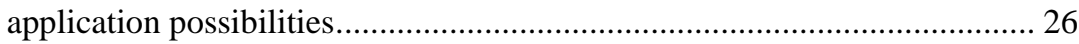

1.7. The car operating vibration and their detection methods .............................. 27

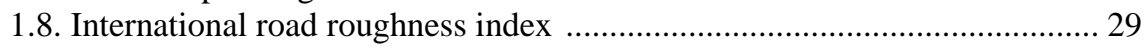

1.9. Theoretical and experimental research assumptions ..................................... 30

1.10. Conclusions of the first chapter and formulation of the tasks of thesis ..... 31

2. NUMERICAL ANALYSIS OF DYNAMIC PROPERTIES OF A CAR WITH SEMI-ACTIVE SUSPENSION AND ROAD IRREGULARITIES

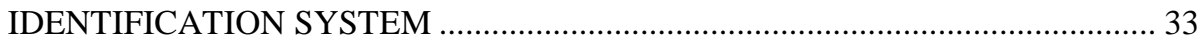

2.1. Mathematical model of a car with mounted laser distance sensor ................ 33

2.2. Nonlinearity of damping and stiffness elements .......................................... 37

2.3. Time delay for shock absorbers ............................................................. 42

2.4. Single and continuous bumps on the road surface ....................................... 43

2.5. Validation of the half car mathematical model with mounted laser

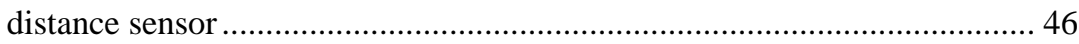

2.6. Analysis of a car moving through road bumps with different suspension

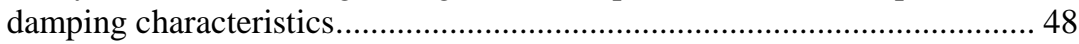

2.7. Analysis of passive and semi-active suspensions controlled by

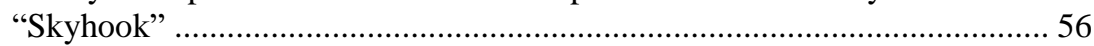

2.8. Compensation for a car sprung mass oscillations ......................................... 58

2.8.1. Compensation of displacement of sprung mass in the vertical direction in the centre of gravity ...................................................... 59

2.8.2. Compensation of the pitch of sprung mass ...................................... 59

2.8.3. Compensation of the fixation angle of the laser sensor ................... 60

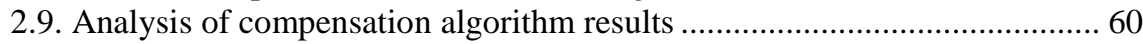

2.10. Algorithms of semi-active suspension control with road irregularities

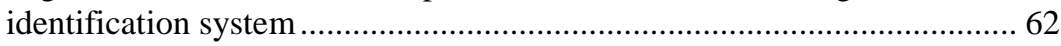

2.10.1. Shock absorbers damping value selection algorithm according the height of the irregularities ....

2.10.2. Shock absorbers damping value selection algorithm

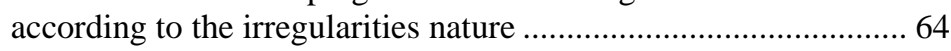

2.10.3. Shock absorbers damping value selection algorithm according to maximum irregularities height and nature, depending on the speed of movement.................................................. 66

2.11. Analysis of the results of semi-active suspension control principles ......... 67

2.12. Summary of control principles................................................................... 74

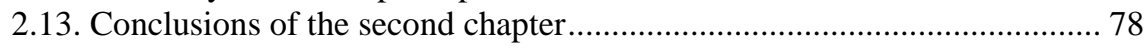

3. EXPERIMENTAL RESEARCH OF A CAR WITH SEMI-ACTIVE

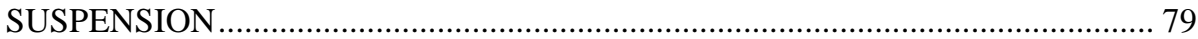

3.1. Method of dynamic characteristics of a car moving through a half

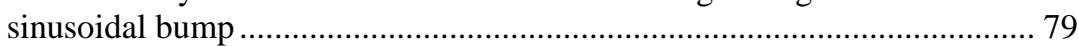

3.2. Equipment for measuring a car dynamic parameters .................................. 82

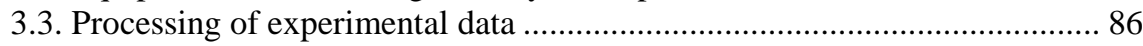


3.4. Experimental research on road roughness identification methods

3.5. Half sinusoidal bump in experimental research ........................................ 90

3.6. Experimental research on laser sensor mounting position ............................ 91

3.7. Analysis of the results of experimental research on the compensation algorithm.

3.8. Analysis of the results of experimental research on semi-active suspension with road irregularities identification system

3.9. Conclusion of the third chapter................................................................... 97

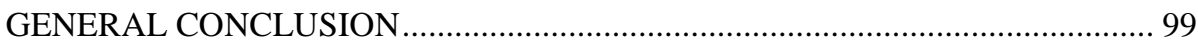

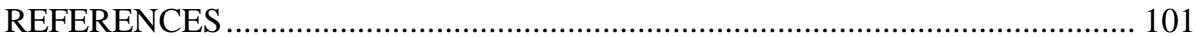

LIST OF SCIENTIFIC PUBLICATIONS BY THE AUTHOR ON THE TOPIC

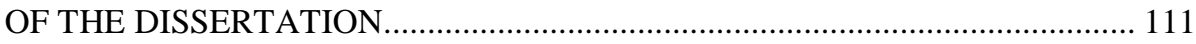

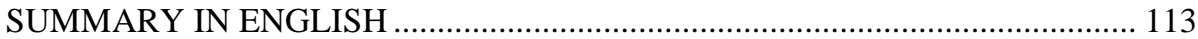

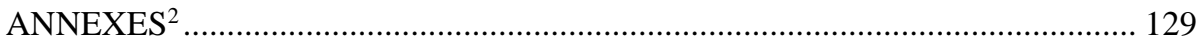

Annex A. Matlab code for the input of the original half-car model.................. 131

Annex B. Specification of equipment used in experimental testing ................. 133

Annex C. Author's declaration of academic integrity ..................................... 137

Annex D. The co-authors' agreements to provide publications material in the doctoral dissertation............................................................... 138

Annex E. Copies of scientific publications by the author on the topic of the dissertation

${ }^{2}$ The annexes are supplied in the attached compact disc. 



\section{Ivadas}

\section{Problemos formulavimas}

Naujos automobilių technologijos leidžia padidinti eismo saugumą bei pagerinti vairuotojų ir keleivių komfortą. Svarbus saugumo veiksnys - padangos su kelio paviršiumi kontakto buvimas automobiliui judant skirtingo lygumo dangomis ir važiuojant per ịvairių formų kelio nelygumus. Tam turi įtakos padangos, pakabos standumo ir slopinimo elementai, konstrukcija bei daugelis kitų komponentų.

Automobilių gamintojai ir mokslininkai daug dèmesio skiria pakabos dinaminių procesų analizei, taip pat konstrukcijų tobulinimui. Pasyvias pakabas automobiliuose keičia pusiau aktyvios arba aktyvios, naudojami papildomi įtaisai pakabos darbui gerinti, kuriami nauji valdymo algoritmai, siekiant pagerinti pakabos elementų darbą.

Automobilių gamintojų dažnai naudojamas pusiau aktyvios pakabos valdymo algoritmas „Skyhook“ (liet. užsikabinęs už dangaus) leidžia automobiliui judèti saugiau ir komfortiškiau, palyginti su pasyvią pakabą turinčiu automobiliu. Pagrindinis „Skyhook“ valdymo principo trūkumas - pakabos charakteristikos keičiamos tik tada, kai ratas užvažiuoja ant nelygumo, todèl tikslinga amortizatorių pasipriešinimo jègą keisti prieš ratui užvažiuojant ant nelygios kelio dangos. Todèl reikia naudoti papildomus jutiklius, skirtus kelio nelygumų aukščiui nustatyti. Kelio nelygumo aukšti galima nustatyti su lazeriniu atstumo jutikliu. Jutiklio 
montavimo vieta galima ant amortizuotos ir neamortizuotos masės. Tačiau matuojant atstumą nuo automobilio amortizuotos masès iki kelio paviršiaus susiduriama su tam tikrais sunkumais. Greitejjančio, stabdomo ar manevruojančio automobilio kẻbulas svyruoja. Dèl to jutiklio išmatuotos reikšmès gaunamos netikslios, kai automobilio ratai užvažiuoja ant nelygumo. Todèl norint panaudoti lazerinio jutiklio signalą, pirmiausia reikia jị pakoreguoti. Kitas labai svarbus etapas - signalo panaudojimas elektroniniu būdu valdomos pakabos veiklai gerinti. Reikia sukurti teisingą algoritmą, kurị naudojant pusiau aktyviose pakabose būtų galima ịvertinti būsimus kelio nelygumus bei momentinę automobilio padètị.

\section{Darbo aktualumas}

Elektroniniu būdu valdomos pakabos veikimo gerinimas glaudžiai susijęs su eismo sauga keliuose. Inovatyvių technologijų ịdiegimas ị naujus automobilių modelius leidžia padidinti saugumą ir vairuotojo bei keleivių komfortą.

Kelio paviršiaus nustatymas prieš automobiliui užvažiuojant ant nelygumo leidžia paruošti elektroniniu būdu valdomus slopinimo elementus pagal būsimas sąlygas. Taip įveikiami kelio nelygumai su mažesniais amortizuotos masès vertikaliais svyravimais ir išlaikoma rato su kelio paviršiumi sankiba. Taip pat sukauptą informacija apie pakabos veikimą esamomis sąlygomis leidžia numatyti, kaip svyruotų amortizuotos ir neamortizuotos masès važiuojant tam tikra kelio danga.

Kelio paviršiaus nelygumo nustatymas automobiliui važiuojant leidžia kaupti informaciją apie kelių būklę, taip pat, perduodant informaciją kitoms transporto priemonèms ar infrastruktūros elementams, turèti ịtakos jų veikimui. Informacija apie kelius gali būti perduodama kelius prižiūrinčioms įmonèms, taip gerinant kelių būklę.

\section{Tyrimų objektas}

Darbo tyrimų objektas - lengvojo automobilio su kelio paviršiaus nustatymo sistema ir pusiau aktyvia pakaba dinaminiai parametrai, važiuojant nelygia kelio danga. 


\section{Darbo tikslas}

Ištyrus automobilio pusiau aktyvią pakabą, sukurti algoritmą, kurị naudojant būtų nustatomi kelio nelygumai, sumažinti nuo jų priklausantys vertikalieji automobilio svyravimai.

\section{Darbo uždaviniai}

Darbo tikslui pasiekti reikia spręsti šiuos uždavinius:

1. Išanalizuoti pusiau aktyvių amortizatorių valdymo metodus ir kelio nelygumų nustatymo būdus.

2. Patikslinti išilginị pusès automobilio matematini modelị, veikiantị su standumo ir slopinimo elementų netiesinèmis charakteristikomis, amortizatorių uždelsimu, ir galimybę nustatyti kelio nelygumus.

3. Sukurti kompensavimo algoritmą kelio paviršiaus nelygumui nustatyti automobiliui važiuojant pastoviu greičiu.

4. Panaudojant gautą informaciją apie kelio nelygumus ir patobulinus pusiau aktyvios pakabos valdymo algoritmus, sumažinti automobilio vertikaliuosius svyravimus (automobilių pusiau aktyvios pakabos valdymo tobulinimas).

5. Parinkti racionalią lazerinio atstumo jutiklio montavimo vietą, tinkančią kelio profiliui nustatyti prieš ratui užvažiuojant ant nelygumo.

6. Eksperimentiškai ištirti ir palyginti važiuojančio automobilio, su žinomu ir patobulintu pusiau aktyvios pakabos valdymo algoritmu, dinaminius parametrus.

\section{Tyrimų metodika}

Darbe naudojami teoriniai ir eksperimentiniai tyrimų metodai.

Teorineje dalyje taikyti matematinio modeliavimo metodai. Važiuojančio automobilio dinaminiams parametrams apskaičiuoti naudotas Matlab/Simulink programinis paketas, rezultatų analizè atlikta su kitais Matlab papildiniais - Curve Fitting, Signal Analysis.

Eksperimentiniai tyrimai atlikti trimis automobiliais. Dinaminiams parametrams fiksuoti naudota Corrsys-Datron, Kistler, dSpace ir kitų gamintojų įranga. Bandymams filmuoti naudota lèto veikimo funkciją turinti kamera Garmin VIRB. 


\section{Darbo mokslinis naujumas}

Rengiant disertaciją buvo gauti šie transporto inžinerijos mokslui nauji rezultatai:

1. Patikslintas pusès automobilio su papildomu lazeriniu atstumo jutikliu matematinis modelis. Modelis validuotas eksperimentiniais tyrimais. Slopinimo ir standumo elementai aprašyti netiesinėmis funkcijomis bei įtrauktas slopinimo elementų uždelsimas, turintis įtakos amortizuotos masès dinamikai.

2. Sukurtas kompensavimo algoritmas, leidžiantis matematiškai eliminuoti amortizuotos masès svyravimus, atsirandančius dèl automobilio greitėjimo, stabdymo, kelio nelygumų. Tai leidžia išmatuoti kelio nelygumų aukšti ir formą.

3. Nustatyta racionali kelio paviršiui nustatyti naudojamo lazerinio atstumo jutiklio montavimo vieta ant automobilio amortizuotos masès.

4. Pusiau aktyvi pakaba, veikianti su patobulintais algoritmais ir kelio nelygumų nustatymu, sumažina automobilio vertikaliuosius svyravimus, priklausančius nuo kelio paviršiaus.

\section{Darbo rezultatų praktinè reikšmè}

Gauti tyrimų rezultatai leidžia praplèsti žinias apie automobilio judejjimo dinamiką, keičiant amortizatorių pasipriešinimo jègas.

Patikslintas pusès automobilio su sumontuotu papildomu lazeriniu atstumo jutikliu matematinis modelis gali būti naudojamas tiriant automobilių pakabas.

Išrinktas geriausias iš patobulintų pusiau aktyvios pakabos valdymo algoritmų gali būti diegiamas projektuojant automobili su pusiau aktyvia pakaba ir kelio nelygumų nustatymo sistema.

Kelio paviršiaus matavimas ir rezultatų apdorojimas svyravimų kompensavimo modeliu leidžia rezultatus panaudoti pusiau aktyvios pakabos valdymo tikslesniam veikimui. Taip pat informacija apie kelio paviršiaus būklę esamu laiku gali būti panaudota kitų automobilio saugumo sistemų veikimui ir perdavus informaciją ị inovatyvias kelio infrastruktūros sistemas ar su kelių priežiūra susijusias įmones, kelių būklès gerinimui. 


\section{Ginamieji teiginiai}

1. Norint gauti kuo tikslesnę informaciją apie kelio paviršiaus nelygumą, reikia iš lazerinio atstumo jutiklio, pritvirtinto prie automobilio kẻbulo, gauto signalo kompensuoti automobilio svyravimus bei vertikaliuosius poslinkius, susijusius su transporto priemonių judejjimu.

2. Naudojant pusės automobilio matematinị modelị su papildomu lazeriniu atstumo jutikliu galima nustatyti nelygumo aukštị ir formą, ịvertinti automobilio padètị esamu laiku.

3. Informacija apie kelio paviršių prieš ratui užvažiuojant ant jo gali būti panaudota pusiau aktyvių amortizatorių valdymo algoritmo gerinimui.

4. Matematiniu modeliavimu nagrinèjant elektroniniu būdu valdomas automobilių pakabas slopinimo ir standumo elementai turi būti aprašyti netiesinèmis funkcijomis, ir įvestas amortizatorių mechaninių ir elektrinių sistemų uždelsimas.

\section{Darbo rezultatų aprobavimas}

Disertacijos tema yra publikuoti aštuoni moksliniai straipsniai: trys - mokslo žurnaluose, įtrauktuose i Clarivate Analytics Web of Science duomenų bazę (Surblys et al. 2019, Žuraulis et al. 2019, Surblys et al. 2017); keturi - kitų tarptautinių bazių leidiniuose (Surblys et al. 2018; Surblys, Sokolovskij 2018; Mužar et al. 2018; Janhar et al. 2018); vienas - recenzuojamoje tarptautinès konferencijos medžiagoje (Levulytė et al. 2016).

Disertacijoje atliktų tyrimų rezultatai buvo paskelbti keturiose mokslinėse konferencijose Lietuvoje ir užsienyje:

- 12-oje tarptautinèje mokslinejje praktinejje konferencijoje Criminalistics and forensic expertology: science, studies, practice $2016 \mathrm{~m}$. Varšuvoje (Lenkija);

- 13-oje saugumo konferencijoje XIII Międzynarodowa konferencję hamulcowa i bezpieczeństwa 2017 m. Lodzèje (Lenkija);

- 21-oje jaunujų mokslininkų konferencijoje Mokslas - Lietuvos ateitis. Transporto inžinerija ir vadyba $2018 \mathrm{~m}$. Vilniuje.

- Tarptautineje konferencijoje Vision Zero for Sustainable Road Safety in Baltic Sea Region 2018 m. Vilniuje. 


\section{Disertacijos struktūra}

Disertaciją sudaro ịvadas, trys skyriai ir bendrosios išvados. Taip pat yra penki priedai.

Darbo apimtis yra 129 puslapiai be priedų, tekste panaudota 59 numeruotos formulès, 66 paveikslai ir 11 lentelių. Rašant disertaciją buvo panaudota 113 literatūros šaltinių. 


\section{1}

\section{Lengvojo automobilio su pusiau aktyvia pakaba valdymo algoritmų apžvalga}

Skyriuje apžvelgiama mokslinė literatūra disertacijos tema. Pateikiama lengvuosiuose automobiliuose naudojamų pakabų analizè, taip pat pasaulyje naudojamų pakabų valdymo principų apžvalga. Apžvelgiami kelio paviršiaus nelygumų nustatymo būdai, mokslinèje literatūroje naudojami pakabų matematiniai modeliai, atliekama virpesių, veikiančių vairuotoją ir keleivius, analizè, taip pat pagrindžiamas pusiau aktyvios pakabos pasirinkimas.

Skyriaus tematika paskelbtos penkios publikacijos (Surblys et al. 2017; Surblys, Sokolovskij 2018; Janhar et al. 2019; Surblys et al. 2019; Žuraulis et al. 2019). 


\subsection{Lengvuosiuose automobiliuose naudojamy̨ pakabų analizè}

Automobilio pakabos paskirtis yra išlaikyti visą statini transporto priemonès svorį; užtikrinti kuo geresnį sukibimą tarp rato padangos ir kelio paviršiaus; garantuoti ratų pasukamumą; sumažinti kẻbulo pasvirimą; užtikrinti keleivių komfortą ir gerą valdomumą (Rajamani 2006, Wong 2001).

Klasikinèje automobilių pakaboje dažniausiai naudojami trys elementai (1.1 pav.) (Savaresi et al. 2010):

- standumo elementas - dažniausiai cilindrinè spyruoklė, kuri priešinasi pakabos pailgejjimui ir suspaudimui. Šiam elementui tenka visa statinè apkrova.

- slopinimo elementas - dažniausiai naudojamas hidraulinis amortizatorius, kuris slopina amortizuotos masès svyravimus (Skačkauskas et al. 2017).

- mechaniniai elementai, kurie sujungia neamortizuotus pakabos elementus su amortizuotu elementu (automobilio kèbulu).

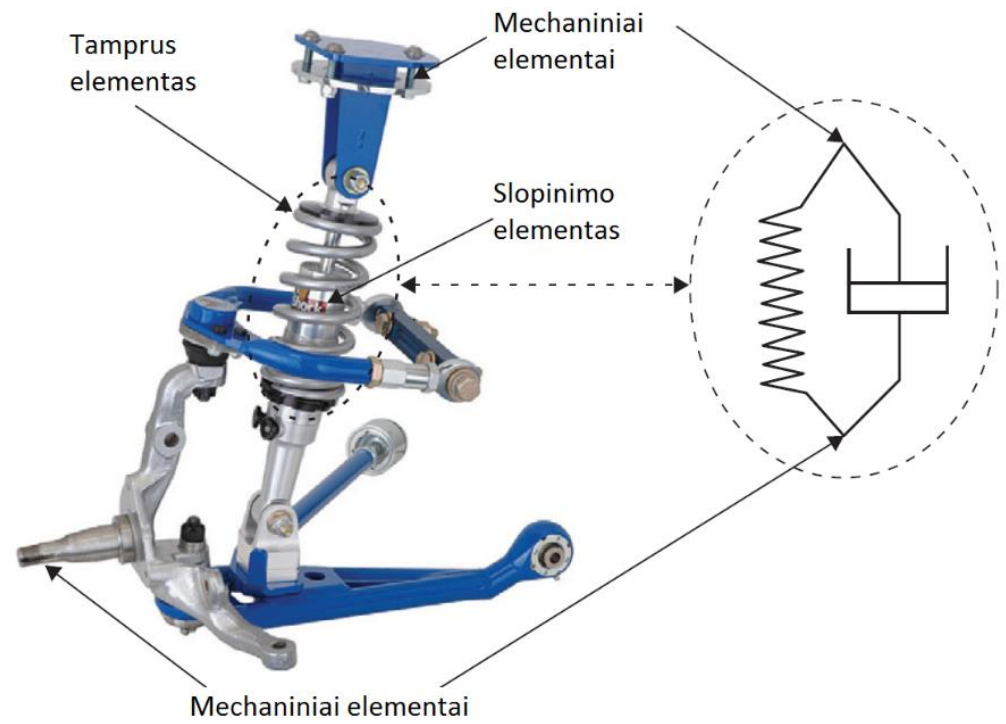

1.1 pav. Klasikinė pakabos sistema ir elementų žymèjimas (Savaresi et al. 2010)

Fig. 1.1. Classical suspension system and elements marking (Savaresi et al. 2010)

Klasikinejje pakaboje naudojami pasyvūs slopinimo elementai. Pasyvi pakaba negali keisti slopinimo ir standumo jëgų charakteristikų važiuojant automobiliui, 
nes slopinimo elementams nèra naudojamas papildomas energijos šaltinis. Šis pakabos tipas yra paprastos konstrukcijos (Skrickij et al. 2018). Jai pagaminti reikalingos mažesnès nei pusiau aktyvios ar aktyvios pakabos gamybos sąnaudos. Tokia pakaba dažniausiai montuojama lengvuosiuose automobiliuose. Kadangi pasyvi pakaba negali keisti standumo ir slopinimo jègų, ji gali užtikrinti nustatytas darbines sąlygas, veikiant numatytam slopinimui (Skačkauskas, Žuraulis 2015). Važiuojant automobiliui skirtingomis dangomis slopinimas išlieka toks pat, o tai neužtikrina didelio važiavimo komforto, valdomumo ir stabilumo (Fateh 2009). Pasyvių slopinimo ir standumo elementų veikimo charakteristikos yra pavaizduotos 1.2 paveiksle. Grafikuose pažymèta $F_{k}$-pakabos standumo jèga, $\Delta z$-pakabos eigos poslinkis, $F_{d}$-pakabos slopinimo jèga, $\Delta \dot{z}$ - pakabos eigos greitis.
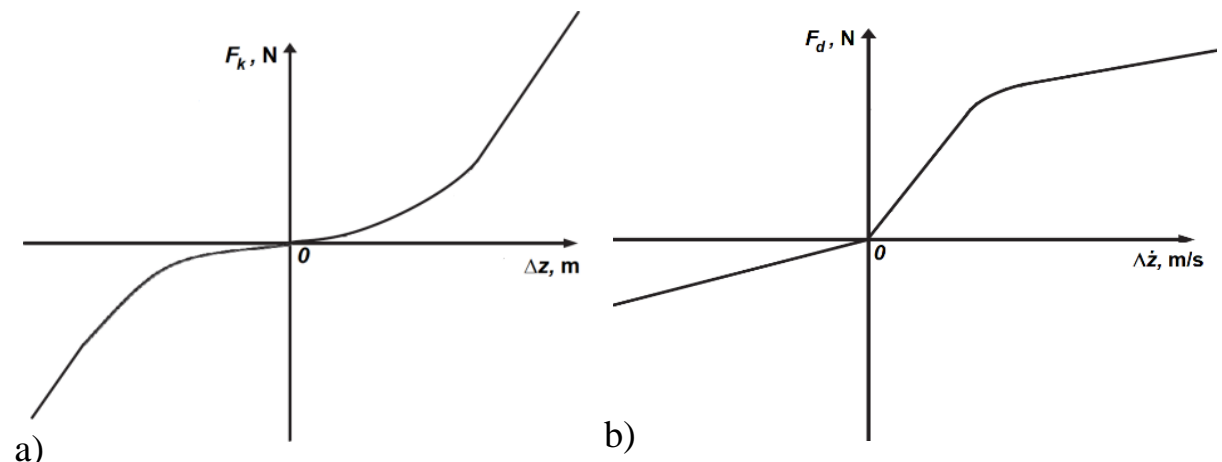

1.2 pav. Grafiškai pavaizduotos pasyvios pakabos elementų charakteristikos:

a) standumo elementas; b) slopinimo elementas (Li, Chen 2018)

Fig. 1.2. Graphical representation of passive suspension characteristics: a) stiffening element; b) damping element ( $\mathrm{Li}$, Chen 2018)

Kaip standumo elementas, dažniausiai naudojama cilindrinė spyruoklè, kurios charakteristika yra tiesinè, o standumo koeficientas apskaičiuojamas pagal formulę (Bosch 2007):

$$
k=\frac{G d^{4}}{32 R^{3} n},
$$

čia $G$ - šlyties modulis; $d$-spyruoklès apvijos skersmuo; $R$-vidutinis vidinis apvijos spindulys; $n$ - apvijų skaičius.

Pusiau aktyvios pakabos ypatybè, kad slopinimo elementas, atsiradus poreikiui, gali keisti savo charakteristiką. Iš esmès pusiau aktyvios pakabos sistema yra geresnè už aktyvią pakabą dèl universalumo, prisitaikymo, didesnio naudingumo koeficiento (Liu et al. 2005). 
Pusiau aktyvi pakaba valdoma dažniausiai „Skyhook“ principu (Krauze, Kasprzyk 2016b). Toks pakabos tipas ir jos valdymo konceptas sukurtas 1970 m. (Crosby, Karnopp 1973; Karnopp et al. 1974). Pusiau aktyvi pakaba buvo sukurta kaip alternatyva brangiai, daug energijos naudojančiai aktyviai pakabai (Guglielmino et al. 2008). Spyruoklès standumo charakteristikų keitimas yra sudètingas procesas, todèl pusiau aktyvioje pakaboje vyksta tik amortizatoriaus pasipriešinimo jègų reguliavimas, o standumo elementas naudojamas kaip ir pasyvioje sistemoje - cilindrinè spyruoklè.

Literatūroje labai plačiai nagrinèjama pusiau aktyvi pakaba. Tyrimų sritys pasiskirsčiusios ị dvi pagrindines grupes:

- slopinimo elemento charakteristikų nustatymas;

- pusiau aktyvios pakabos valdymo tobulinimas.

Pasaulio mokslininkai tyrinejja pusiau aktyvias pakabas (Savaresi, Spelta 2009; Savaresi et.al. 2010; Mulla, Unaune 2013; Pei et al. 2016; Rao et al. 2010; Krauze, Kasprzyk 2016a; Williams 1994; Emam, Ghany 2012; Marzbanrad et al. 2013; Hong et al. 2002; Canale et al. 2006; Suzuki, Takahashi 2012; Kashem et al. 2015; Aly, Salem 2013; Pepe, Carcaterra 2016; ZF Friedrichshafen AG 2011; Ślaski 2011; Dąbrowski, Ślaski 2016).

Pusiau aktyvios pakabos konstrukcijos schema pavaizduota 1.3 paveiksle.

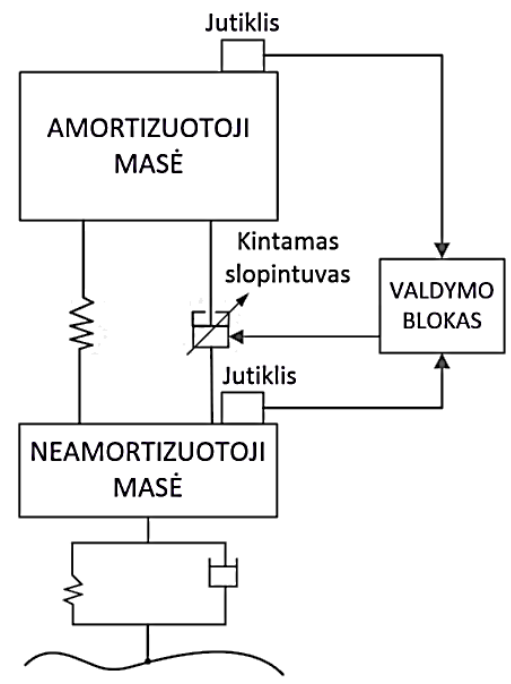

1.3 pav. Pusiau aktyvios pakabos schema (Wong 2008)

Fig. 1.3. Semi-active suspension scheme (Wong 2008) 
Pusiau aktyvios pakabos amortizatoriuose pasipriešinimo jèga keičiama dviem būdais: didinant arba mažinant kiaurymès skerspjūvio plotą, esančią amortizatoriuje; keičiant skysčio klampą (Wong 2008). Pusiau aktyvioje sistemoje naudojami du pagreičio jutikliai: pirmasis pritvirtintas prie neamortizuotos masès (dažniausiai prie rato stebulès arba prie pačio amortizatoriaus), antrasis - irengiamas amortizuotoje masėje, t. y. automobilio kèbule. Kiekvienam automobilio ratui montuojami atskiri pagreičio jutikliai, bet kartais kèbulo pagreičio jutiklis naudojamas vienas dviems galiniams ratams (ZF Friedrichshafen AG. 2011). Taip pat yra tyrinejjama ir vieno pagreičio jutiklio sistema (Savaresi, Spelta 2009). Pagal gautus parametrus valdymo blokas apdoroja duomenis ir siunčia signalą į amortizatorių. Reikiamai pasipriešinimo jègai nustatyti naudojami 4 pagrindiniai pusiau aktyvios pakabos valdymo principai, kurie pateikti 1.2 poskyryje.

Elektroniniu būdu valdomi pusiau aktyvūs amortizatoriai automobiliuose naudojami trijų tipų (Savaresi et al. 2010):

- turintys elektrohidraulini slopintuvą (EH). Irengiamas elektromagnetinis vožtuvas amortizatoriaus viduje arba išorèje. Šių tipų amortizatoriuose slopinimas keičiamas didinant arba mažinant skysčio pratekèjimo angą. Tai laikoma klasikine pusiau aktyvios sistemos amortizatorių konstrukcija. Amortizatorius gamina įmonè $Z F$ Sachs $A G$ ir kiti gamintojai. Ideali EH amortizatoriaus charakteristika yra reiškiama sąlyga:

$$
\left\{\begin{array}{l}
F_{c}(\Delta \dot{z}, I)=c(I) \Delta \dot{z}+F_{0} \operatorname{sign}(\Delta \dot{z}), \\
c(I)=\gamma I+c_{0}, \\
0 \leq I \leq I_{\max },
\end{array}\right.
$$

čia $F_{c}$-amortizatoriaus pasipriešinimo jèga; $\Delta \dot{z}$-pakabos eigos greitis; $I$ - srovės stipris, reikalingas elektromagnetinio vožtuvo valdymui; $c_{0}-$ minimalus pasipriešinimo koeficientas, kai signalas yra išjungtoje padètyje; $\gamma$ - koeficientas; $F_{0}$ - amortizatoriaus vidinè trinties jèga. 1.4 paveiksle pavaizduotos $\mathrm{EH}$ amortizatoriaus dvi charakteristikos, kai valdymui naudojami skirtingi srovès stipriai.

- magnetorheologiniu skysčiu (MR) veikiantys amortizatoriai. MR skystis - tai alyva su skirtingu kiekiu mikro dydžio geležies dalelių, padengtų antikoaguliacine medžiaga. MR skysčio aktyvi būsena, kai ji kerta magnetinis laukas, ir klampumas keičiasi, atsižvelgiant ị magnetinio lauko dydį. Magnetinio lauko neveikiamas skystis išlaiko pastovų alyvos klampumą (Choi, Han 2013; Ata, Salem 2017). 


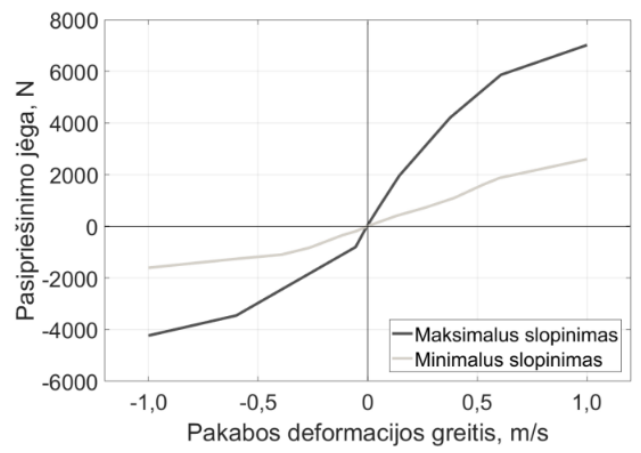

1.4 pav. Amortizatoriaus turinčio elektrohidraulinị slopintuvą charakteristika (Wang, Hou 2019)

Fig. 1.4. Shock absorber with electrorheological damper characteristics

(Wang, Hou 2019)

Ideali MR amortizatoriaus charakteristika yra reiškiama sąlyga (Savaresi et al. 2005):

$$
\left\{\begin{array}{l}
F_{c}(\Delta \dot{z}, I)=c(I) \Delta \dot{z}+F_{M R}(I, \Delta \dot{z}) \\
0 \leq I \leq I_{\max }
\end{array}\right.
$$

čia $c_{0}$ - minimalus pasipriešinimo koeficientas, kai skystis amortizatoriuje teka laisvai, pro stūmoklio angas; $I$ - srovès stipris, reikalingas sukurti magnetinị lauką apvijose; $F_{M R}$ - trinties jèga tarp MR skysčio ir stūmoklio angų. Ideali amortizatoriaus charakteristika matoma 1.5 paveiksle. Pateiktos dvi priklausomybès, kai naudojami skirtingi srovès stipriai.

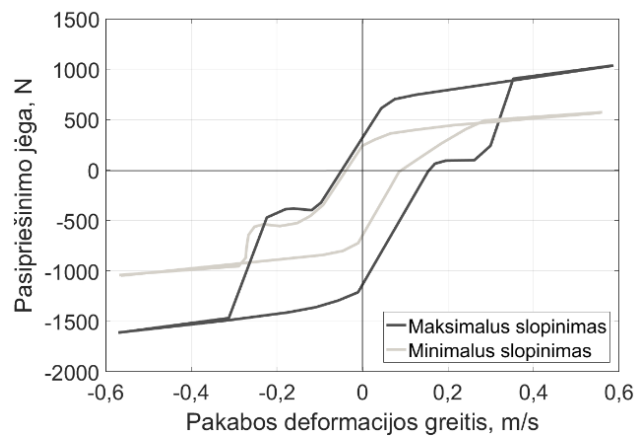

1.5 pav. Ideali magnetorheologiniu skysčiu veikiančio amortizatoriaus charakteristika (Ma et al. 2017)

Fig. 1.5. Ideal magnetorheological fluid operating shock absorber characteristics (Ma et al. 2017) 
- elektrorheologiniu skysčiu (ER) veikiantys amortizatoriai. Technologija labai panaši ị MR skysčiu veikiančius amortizatorius, tik skystis keičia klampą, kai ji kerta ne magnetinis laukas, o elektrinis laukas (Choi et al. 2001; Ata, Salem 2017).

Ideali ER amortizatoriaus charakteristika yra reiškiama sąlyga (Savaresi et al. 2005):

$$
\left\{\begin{array}{l}
F_{c}(\Delta \dot{z}, V)=c_{0} \Delta \dot{z}+F_{E R}(V, \Delta \dot{z}), \\
0 \leq V \leq V_{\max },
\end{array}\right.
$$

čia $c_{0}$ - minimalus pasipriešinimo koeficientas, kai skystis amortizatoriuje teka laisvai, pro stūmoklį; $V$ - ịtampa, reikalinga sukurti elektrinị lauką; $F_{E R}$-trinties jèga tarp ER skysčio ir stūmoklio paviršiaus. Ideali amortizatoriaus charakteristika matyti 1.6 paveiksle. Pateiktos dvi priklausomybės, kai valdymui naudojamos skirtingos įtampos.

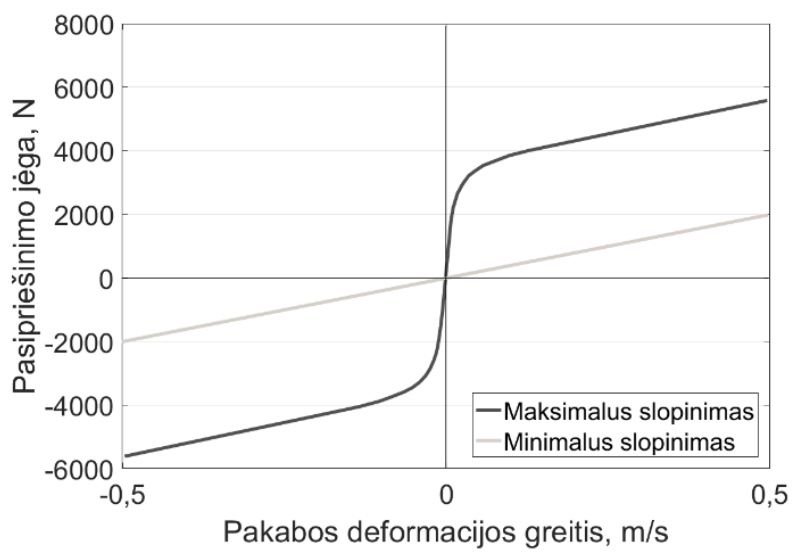

1.6 pav. Ideali elektrorheologiniu skysčiu veikiančio amortizatoriaus charakteristika (Savaresi et al. 2010)

Fig. 1.6. Ideal electrorheological fluid operating shock absorber characteristics (Savaresi et al. 2010)

Aktyvi pakaba nuo pusiau aktyvios pakabos skiriasi tuo, kad keičiamos ne tik slopinimo, bet ir standumo jègos (Mulla, Unune 2013). Aktyvi pakaba, kaip ir pusiau aktyvi pakaba, naudoja pagreičio jutiklius, kai siekiama išsiaiškinti amortizuotos ir neamortizuotų masių pagreičius ir poslinkius. Aktyvioje pakaboje standumo ir slopinimo keitimui būtinas didelis galingumas 5-10 kW, kai pusiau aktyviai pakabai tik 10-20 W (Liu et al., 2014). 
Pakeitus amortizatorius iš pasyvių i pusiau aktyvius, pagerèja važiavimo komfortas, taip pat sumažèja svyravimų nusistovejjimo laikas (Phalke 2016). Tyrèjų atliktas matematinis modeliavimas parodè, kad su pusiau aktyvia pakaba turintis matematinis modelis svyruodamas nusistovi iki $51 \%$ greičiau, palyginti su pasyvią pakabą turinčiu modeliu.

Transporto priemonès važiavimas minimaliu slopinimu sureguliuotais amortizatoriais yra pavojingesnis nei amortizatorių sureguliavimas maksimaliu slopinimu. Važiuojant automobiliu, kai pakabos slopinimas didelis, komfortas yra prastesnis. Pareto optimalus (Pareto-optimal points) slopinimas pavaizduotas 1.7 paveiksle. Grafike išskirti taškai, kai didžiausias komfortas yra $d_{A}=1890 \mathrm{~N} \cdot \mathrm{s} / \mathrm{m}$, o didžiausias saugumas $d_{A}=4580 \mathrm{~N} \cdot \mathrm{s} / \mathrm{m}$, kai $d_{A}-$ amortizatorių slopinimo koeficientas (Schiehlen, Iroz 2015).

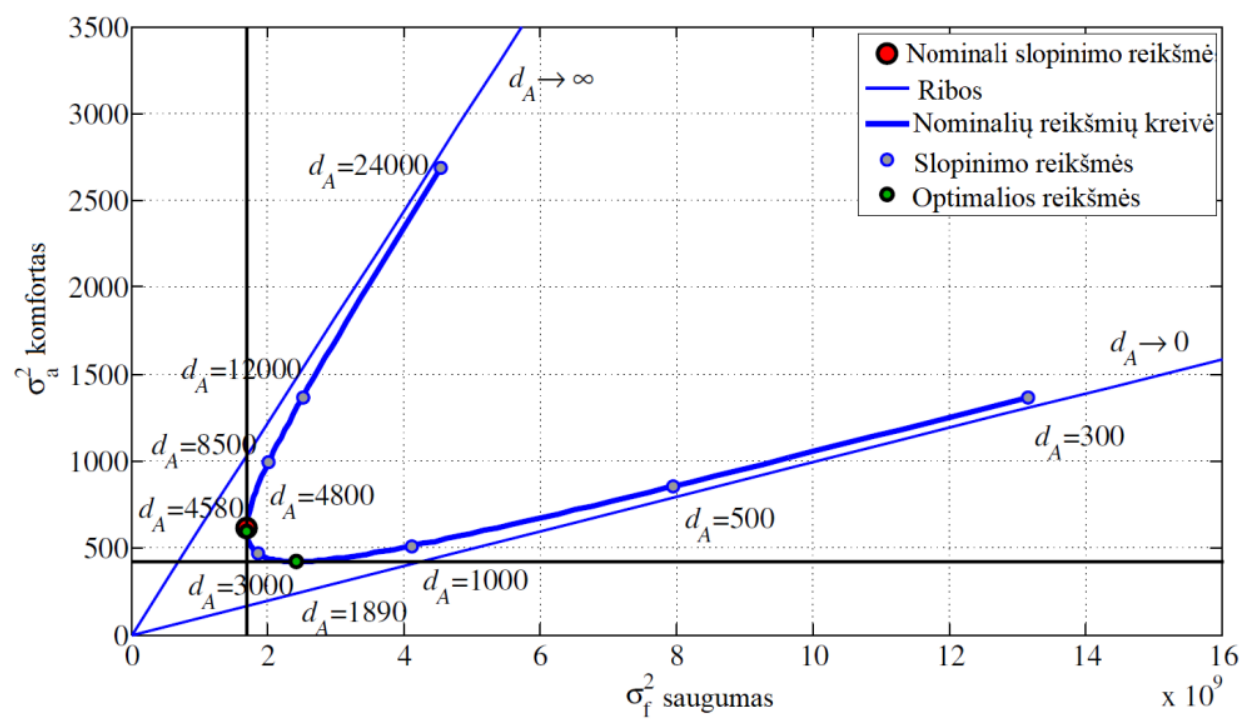

1.7 pav. Pareto optimalus slopinimas $d_{a}$ (Schiehlen, Iroz 2015)

Fig. 1.7. Pareto-optimal damping $d_{a}$ (Schiehlen, Iroz 2015)

Tyrimas (Mostaani et al. 2011) atskleidè, kad transporto priemonių didžiausi amortizuotos masès vertikalūs svyravimai važiuojant $60-110 \mathrm{~km} / \mathrm{h}$ greičiu yra važiuojant $60 \mathrm{~km} / \mathrm{h}$, didèjant greičiui svyravimai mažeja. Pasiekus $110 \mathrm{~km} / \mathrm{h}$ greitị svyravimai sumažèja maždaug $25 \%$, palyginti su svyravimais, kai važiuojama $60 \mathrm{~km} / \mathrm{h}$ greičiu. Padangos kontaktinis plotas tampa nejautrus mažiems nelygumams, taip padanga peršoka nedideles duobes ir iškylimus. Bandymai atlikti naudojant Sayers kelio nelygumų modeli (Sayers, Karamihas 1996). 


\subsection{Pusiau aktyvios pakabos valdymo principu analizè}

Pasaulyje tyrëjai dideli dèmesi skiria pusiau aktyvios pakabos valdymo principams kurti ir tobulinti. Vieni iš jų skirti vairuotojo ir keleivių komfortui didinti, kiti - rato sąveikai su keliu gerinti, važiavimo saugumui didinti. 1.1 lentelèje pateikta naudojamų valdymo principų analizè.

1.1 lentelè. Pusiau aktyvios pakabos valdymo principų analizė

Table 1.1. Analysis of semi-active suspension controls

\begin{tabular}{|c|c|c|}
\hline $\begin{array}{c}\text { Valdymo principo } \\
\text { angliškas pavadinimas }\end{array}$ & Tikslas & Šaltiniai \\
\hline 1 & 2 & 3 \\
\hline Skyhook & $\begin{array}{l}\text { Komforto page- } \\
\text { rinimas }\end{array}$ & $\begin{array}{l}\text { Dutta 2017; Aubouet et al. 2008; } \\
\text { Liu et al. 2005; Rao et al. 2010; } \\
\text { Hong et al. 2002; Sammier } \text { et al. } \\
\text { 2003; Kashem } \text { et al. 2015; Flo- } \\
\text { res et al. 2006; Krauze, Kasprzyk } \\
\text { 2016a; Shamsi, Choupani } 2008\end{array}$ \\
\hline Groundhook & $\begin{array}{l}\text { Rato sąveikos } \\
\text { su keliu pageri- } \\
\text { nimas }\end{array}$ & $\begin{array}{l}\text { Dutta 2017; Valasek, Kortum 2002; } \\
\text { Flores et al. } 2006\end{array}$ \\
\hline Sliding mode & $\begin{array}{l}\text { Komforto page- } \\
\text { rinimas }\end{array}$ & $\begin{array}{l}\text { Alvarez-Sánchez 2013; Yao, Zheng } \\
2006\end{array}$ \\
\hline Preview control & $\begin{array}{l}\text { Komforto ir rato } \\
\text { sąveikos su ke- } \\
\text { liu pagerinimas }\end{array}$ & $\begin{array}{l}\text { Valasek, Kortum 2002; } \\
\text { Hac, Youn 1992; Takaba 2003; Huis- } \\
\text { man et al. 1993; Kitching et al. 1999; } \\
\text { Ahmed, Svaricek 2013; Huis- } \\
\text { man et al. 1993; Çalışkan et al. 2016; } \\
\text { Ahmed, Svaricek } 2014\end{array}$ \\
\hline Optimal & $\begin{array}{l}\text { Komforto ir rato } \\
\text { sąveikos su ke- } \\
\text { liu pagerinimas }\end{array}$ & Kashem et al. 2015 \\
\hline Hळ Clipped Control & $\begin{array}{l}\text { Komforto page- } \\
\text { rinimas }\end{array}$ & $\begin{array}{l}\text { Emam, Ghany 2012; Suzuki, Ta- } \\
\text { kahashi 2012; Sohn et al. } 2000\end{array}$ \\
\hline $\begin{array}{l}\text { Model Predictive Cont- } \\
\text { rol (MPC) }\end{array}$ & $\begin{array}{l}\text { Komforto ir rato } \\
\text { sąveikos su ke- } \\
\text { liu pagerinimas }\end{array}$ & $\begin{array}{l}\text { Canale et al. 2002; Ahmed, Svaricek } \\
2013\end{array}$ \\
\hline
\end{tabular}


1.1 lentelès pabaiga

\begin{tabular}{|c|c|c|}
\hline 1 & 2 & 3 \\
\hline $\begin{array}{l}\text { Hybrid-Model Predictive } \\
\text { Control (Hybrid MPC) }\end{array}$ & $\begin{array}{l}\text { Komforto ir rato } \\
\text { sąveikos su keliu } \\
\text { pagerinimas }\end{array}$ & $\begin{array}{l}\text { Sande et al. 2016; Çalışkan et al. } \\
2016\end{array}$ \\
\hline $\begin{array}{l}\text { Power Driven Damper } \\
\text { Control }(P D D)\end{array}$ & $\begin{array}{l}\text { Komforto page- } \\
\text { rinimas }\end{array}$ & Morselli, Zanasi 2008 \\
\hline $\begin{array}{l}\text { Acceleration Driven } \\
\text { Damper Control }(A D D)\end{array}$ & $\begin{array}{l}\text { Komforto page- } \\
\text { rinimas }\end{array}$ & Savaresi et al. 2004 \\
\hline Mixed $S H-A D D$ & $\begin{array}{l}\text { Komforto page- } \\
\text { rinimas }\end{array}$ & $\begin{array}{l}\text { Savaresi, Spelta 2009; Krauze, } \\
\text { Kasprzyk 2016a }\end{array}$ \\
\hline Single-Sensor & $\begin{array}{l}\text { Komforto page- } \\
\text { rinimas }\end{array}$ & Savaresi, Spelta 2009 \\
\hline $\begin{array}{l}\text { Hybrid (Skyhook + } \\
\text { Groundhook) }\end{array}$ & $\begin{array}{l}\text { Komforto ir rato } \\
\text { sąveikos su keliu } \\
\text { pagerinimas }\end{array}$ & $\begin{array}{l}\text { Dutta 2017; Flores et al. 2006; } \\
\text { Sohn et al. } 2000\end{array}$ \\
\hline Adaptive & $\begin{array}{l}\text { Komforto ir rato } \\
\text { sąveikos su keliu } \\
\text { pagerinimas }\end{array}$ & Pei et al. 2016, Kashem et al. 2015 \\
\hline Fuzzy logic & $\begin{array}{l}\text { Komforto page- } \\
\text { rinimas }\end{array}$ & $\begin{array}{l}\text { Tawwab 2013; Marzbanrad et al. } \\
2013\end{array}$ \\
\hline
\end{tabular}

Iš 1.1 lentelès matyti, kad vieni pusiau aktyvios pakabos valdymo principai yra skirti komfortui, kiti - rato sąveikai su keliu gerinti. Kai kurie valdymo principai naudojami automobiliuose, o kai kurie tik moksliniuose tyrimuose.

Vienas populiariausių valdymo principu yra ,Skyhook“ (Krauze, Kasprzyk 2016b). Valdymo principas naudojamas komforto gerinimui, nes sumažina amortizuotos masès svyravimų amplitudę. Šis valdymo metodas turi du veikimo principus: nepertraukiamas valdymas ir ,ijungta-išjungta“. Šie principai skiriasi tuo, kad amortizatorių pasipriešinimo jègos keičiamas nuolat, kai naudojamas nepertraukiamo valdymo principas, o ,ijungta-išjungta“ - slopinimas ijungiamas arba išjungiamas. Šių principų charakteristikos pavaizduotos 1.8 pav.

1.8 paveiksle pateikta pasipriešino jègos priklausomybe nuo pakabos eigos greičio. ,Ijungta-išjungta“ (a) režimu slopinimas galimas dviejų dydžių - maksimalus arba minimalus, o „nepertraukiamo“ (b) režimo slopinimas nuolat kinta. Galimas kitimas pavaizduotas pilku plotu. 


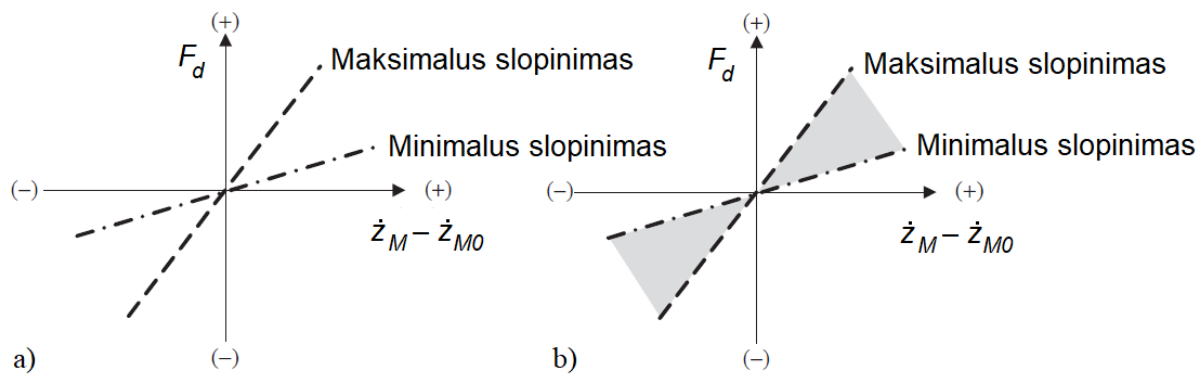

1.8 pav. Pusiau aktyvios pakabos: a), ,ijungta-išjungta“; b) nepertraukiamas valdymo principai (Liu et al. 2005)

Fig. 1.8. Semi-active suspension: a) „On-Off“;

b) Continous control (Liu et al. 2005)

„Nepertraukiamas Skyhook“(Abramov et al. 2009; Ihsan et al. 2009) valdymo principas apibūdinamas vieno laisvès laipsnio sistema, kai pasipriešinimo jèga apskaičiuojama pagal formulę:

$$
F_{s k y}=c_{s k y} \dot{z}_{M}
$$

čia $F_{s k y}-$ „Skyhook“ principu veikiančio amortizatoriaus pasipriešinimo jëga; $\dot{z}_{M}$ - amortizuotos masės greitis; $c_{s k y}$ - pusiau aktyvaus amortizatoriaus, veikiančio „Skyhook“ principu, pasipriešinimo koeficientas. Kadangi pasyvūs amortizatoriai gali tik absorbuoti vibracijos energiją, pusiau aktyvių amortizatoriu pasipriešinimo jèga $F_{s a}$ ir amortizuotos-neamortizuotos masių greičiu skirtumas $\dot{z}_{M}-\dot{z}_{M 0}$ turi atitikti sąlygą:

$$
F_{s a}\left(\dot{z}_{M}-\dot{z}_{M 0}\right) \geq 0 .
$$

Norima jẻga yra $c_{s k y} \dot{z}_{M}$, bet pusiau aktyvūs amortizatoriai gali generuoti šią jègą tik kai $\dot{z}_{M}$ ir $\dot{z}_{M}-\dot{z}_{M 0}$ yra to paties ženklo. Kai $\dot{z}_{M}$ ir $\dot{z}_{M}-\dot{z}_{M 0}$ yra priešingų ženklų, pusiau aktyvūs amortizatoriai gali sukurti jègą, priešingą norimai. Tokiu atveju geriau visai nesukurti pasipriešinimo jègos. Taigi, nepertraukiamo pusiau aktyvaus ,Skyhook“ principu veikiančio amortizatoriaus algoritmas aprašomas sąlyga:

$$
F_{s a}= \begin{cases}c_{s k y} \dot{z}_{M}, \text { kai } \dot{z}_{M}\left(\dot{z}_{M}-\dot{z}_{M 0}\right) \geq 0, \\ 0, & \dot{z}_{M}\left(\dot{z}_{M}-\dot{z}_{M 0}\right)<0 .\end{cases}
$$


Perjungiant slopinimą, vadovaujamasi sandauga $\dot{z}_{M}\left(\dot{z}_{M}-\dot{z}_{M 0}\right)$, kuri vadinama sąlygos funkcija. Kai slopinimas ijungtas, pasipriešinimo jèga aprašoma:

$$
F_{s a}=c_{s a}\left(\dot{z}_{M}-\dot{z}_{M 0}\right),
$$

čia $c_{s a}$ pusiau aktyvaus amortizatoriaus pasipriešinimo koeficientas. Šio koeficiento reikšmė gaunama iš formulių:

$$
c_{s a}= \begin{cases}\frac{c_{s k y} \dot{z}_{M}}{\left(\dot{z}_{M}-\dot{z}_{M 0}\right)}, & \dot{z}_{M}\left(\dot{z}_{M}-\dot{z}_{M 0}\right) \geq 0, \\ 0, & \dot{z}_{M}\left(\dot{z}_{M}-\dot{z}_{M 0}\right)<0 .\end{cases}
$$

Iš sąlygos matyti: kai pakabos eigos greičio ir amortizuotos masės greičio sandauga yra labai maži, reikiamas pasipriešinimo koeficientas didejja. Vadinasi, reikia numatyti pasipriešinimo koeficientų maksimalias $c_{\max }$ ir minimalias $c_{\min }$ reikšmes:

$$
c_{s a}=\left\{\begin{array}{l}
\max \left[c_{\min }, \min \left[\frac{c_{s k y} \dot{z}_{M}}{\left(\dot{z}_{M}-\dot{z}_{M 0}\right)}, c_{\max }\right]\right], \quad\left\{\begin{array}{l}
\dot{z}_{M}\left(\dot{z}_{M}-\dot{z}_{M 0}\right) \geq 0, \\
\dot{z}_{M}\left(\dot{z}_{M}-\dot{z}_{M 0}\right)<0 .
\end{array}\right. \\
c_{\min } .
\end{array}\right.
$$

„Ijungta-išjungta Skyhook“ (Shamsi, Choupani 2008; Carter 1998, Liu et al. 2005) valdymo principas labai panašus ị prieš tai aprašytą principą. Tai iš esmès yra supaprastintas nepertraukiamas valdymo principas. Tokios sistemos amortizatorius veikia kaip pasyvus elementas. Keičiamos minimalios, maksimalios pasipriešinimo reikšmės. „Ijungta-išjungta“ valdymo pasipriešinimo jëga apskaičiuojama pagal sąlygą:

$$
F_{s a}=\left\{\begin{array} { l } 
{ c _ { o n } ( \dot { z } _ { M } - \dot { z } _ { M 0 } ) , } \\
{ 0 , }
\end{array} \quad \left\{\begin{array}{l}
\dot{z}_{M}\left(\dot{z}_{M}-\dot{z}_{M 0}\right) \geq 0, \\
\dot{z}_{M}\left(\dot{z}_{M}-\dot{z}_{M 0}\right)<0 .
\end{array}\right.\right.
$$

čia $c_{\text {on }}$ yra pasipriešinimo koeficientas, kai amortizatorius yra ijungtas. Praktiškai nulinis pasipriešinimo koeficientas negalimas, kai amortizatorius yra išjungtas. Tada pasipriešinimo koeficientas apskaičiuojamas pagal sąlygą:

$$
c_{s a}= \begin{cases}c_{\max }, & \dot{z}_{M}\left(\dot{z}_{M}-\dot{z}_{M 0}\right) \geq 0, \\ c_{\min }, & \dot{z}_{M}\left(\dot{z}_{M}-\dot{z}_{M 0}\right)<0 .\end{cases}
$$

čia $c_{\max }$-pasipriešinimo koeficiento maksimalios ir $c_{\min }$ - minimalios reikšmès. 
Tokiuose amortizatoriuose $c_{\max }$ pasipriešinimo koeficientas turi būti kiek įmanoma didesnis, o $c_{\min }$ kiek įmanoma mažesnis.

„Acceleration Driven Damper Control (ADD)“ (Savaresi et al. 2010) labai panašus metodas ị ,Ijungta-išjungta Skyhook“. Naudojami ne amortizuotų masių greičiai, bet pagreičiai. Praktikoje pagreičius yra lengviau išmatuoti nei greičius, nes naudojami akcelerometrai veikiantys vertikalia kryptimi. Metodas yra orientuotas ị amortizuotos masès komforto padidinimą:

$$
c_{i n}= \begin{cases}c_{\min }, & \ddot{z}_{M}\left(\dot{z}_{M}-\dot{z}_{m}\right) \leq 0, \\ c_{\max }, & \ddot{z}_{M}\left(\dot{z}_{M}-\dot{z}_{m}\right)>0 .\end{cases}
$$

Pasirinkus „Power Driven Damper Control (PDD)“ (Morselli, Zanasi 2008) metodą panaudotos ,port-Hamiltonian“ lygtys (Polyuga, Schaft 2010). Kaip teigiama literatūros šaltiniuose (Morselli, Zanasi 2008; Savaresi et al. 2010), šis metodas pranašesnis už anksčiau minètą ADD metodą - išvengiama amortizuotos masès žemo dažnio svyravimų. Naudojant šį metodą reikia žinoti pakabos standumo koeficientą.

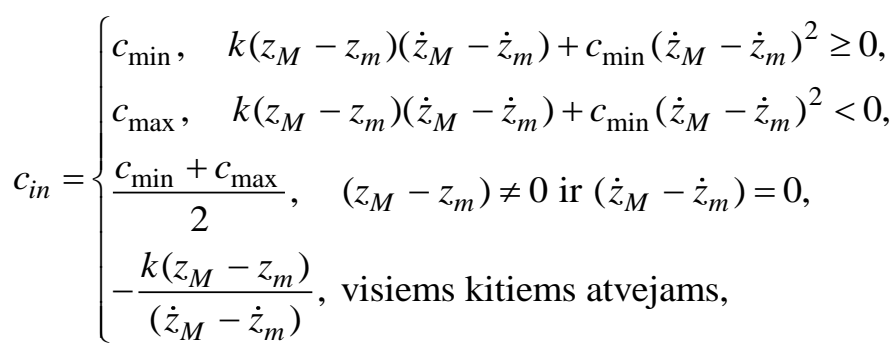

čia $k$ - pakabos standumo koeficientas.

„Ijungta-išjungta Groundhook“ metodas skirtas rato sąveikai su keliu pagerinti, t. y.pasiekti neamortizuotos masės mažesnius svyravimus vertikalia kryptimi. Šio metodo privalumai - geresnis automobilio valdomumas (angl. handling) ir stabilumas (angl. road-holding), palyginti su „Skyhook“ valdymo principu (Valasek, Kortum 2002).

$$
c_{i n}= \begin{cases}c_{\min }, & -\dot{z}_{m}\left(\dot{z}_{M}-\dot{z}_{m}\right) \leq 0, \\ c_{\max }, & -\dot{z}_{m}\left(\dot{z}_{M}-\dot{z}_{m}\right)>0 .\end{cases}
$$

„Nepertraukiamas Groundhook“ metodas veikia kaip ir „Ijungta-išjungta Groundhook“: papildomai leidžia nepertraukiamai keisti pasipriešinimo reikšmes $\operatorname{tarp} c_{\min }$ ir $c_{\max }$ (Valasek, Kortum 2002). 


$$
c_{i n}= \begin{cases}c_{\min }, & -\dot{z}_{m}\left(\dot{z}_{M}-\dot{z}_{m}\right) \leq 0, \\ {\left[c_{\min } ; c_{\max }\right]\left(\frac{\alpha c_{\max }\left(\dot{z}_{M}-\dot{z}_{m}\right)+(1-\alpha) c_{\max } \dot{z}_{m}}{\dot{z}_{M}-\dot{z}_{m}}\right),} & -\dot{z}_{m}\left(\dot{z}_{M}-\dot{z}_{m}\right)>0,\end{cases}
$$

čia $\alpha$ - reguliavimo parametras, kuris kinta nuo 0 iki 1 . Šis parametras parodo, ar parenkamos minimalios ir maksimalios reikšmès, ar jos nepertraukiamai keičiamos. Kai nustatymas $\alpha=1$, metodas veikia kaip ,Ijungta-išjungta Groundhook".

„Mixed Skyhook + ADD“ valdymo metodas yra dviejų - „Skyhook“ ir ADD metodų junginys. „Skyhook“ privalumai akivaizdūs, kai dažniai žemi (arti amortizuotos masès savųjų virpesių dažnio), o ADD metodas sumažina vidutinių ir aukštų dažnių virpesius (virš amortizuotos masės savųjų virpesių dažnio) (Savaresi, Spelta 2009). Iš formulès (1.17), aprašančios veikimo principą, galima teigti, kad:

$$
\begin{cases}\left(\ddot{z}_{M}^{2}-\alpha^{2} \dot{z}_{M}^{2}\right)>0, & \text { ADD metodas parenkamas, } \\ \text { kitais atvejai, } & \text { Skyhook metodas. }\end{cases}
$$

Dydis $\left(\ddot{z}_{M}^{2}-\alpha^{2} \dot{z}_{M}^{2}\right)$ vadinamas ,dažnio intervalo parinkimu“"(Savaresi et al. 2010). Kai dažniai žemi, parenkamas „Skyhook“ valdymo metodas, kai vidutiniai ir aukšti - ADD.

$$
c_{i n}= \begin{cases}c_{\min }, & \text { kitais atvejais, } \\ c_{\max }, & {\left[\left(\ddot{z}_{M}^{2}-\alpha^{2} \dot{z}_{M}^{2}\right) \leq 0 \text { ir } \dot{z}_{M}\left(\dot{z}_{M}-\dot{z}_{m}\right)>0\right],} \\ c_{\max }, & {\left[\left(\ddot{z}_{M}^{2}-\alpha^{2} \dot{z}_{M}^{2}\right)>0 \text { ir } \dot{z}_{M}\left(\dot{z}_{M}-\dot{z}_{m}\right)>0\right],}\end{cases}
$$

čia $\alpha$ - reguliavimo parametras.

„Mixed Skyhook + ADD Single-Sensor“. Tai anksčiau minètas „Mixed Skyhook + ADD“ valdymo metodas. Skirtumas tik toks, kad naudojamas vienas pagreičio jutiklis, kuris matuoja amortizuotos masės pagreitị. Greitis gaunamas atlikus pagreičio skaitinị integravimą. Iš formulès, aprašančios veikimo principą, galima teigti, kad:

$$
\begin{cases}\left(\ddot{z}_{M}^{2}-\alpha^{2} \dot{z}_{M}^{2}\right) \geq 0, & \text { mažas slopinimas, } \\ \text { kitais atvejai, } & \text { didelis slopinimas, }\end{cases}
$$




$$
c_{i n}= \begin{cases}c_{\min }, & \left(\ddot{z}_{M}^{2}-\alpha^{2} \dot{z}_{M}^{2}\right) \geq 0, \\ c_{\max }, & \left(\ddot{z}_{M}^{2}-\alpha^{2} \dot{z}_{M}^{2}\right)<0,\end{cases}
$$

čia, kaip ir anksčiau minèta, dydis $\left(\ddot{z}_{M}^{2}-\alpha^{2} \dot{z}_{M}{ }^{2}\right)$ vadinamas ,dažnio intervalo parinkimu“" (Savaresi et al. 2010).

\subsection{Pakabos valdymo principas su kelio paviršiaus nelygumų nustatymu}

Literatūroje pakabos valdymo principas su kelio paviršiaus nelygumų nustatymu prieš automobiliui užvažiuojant ant paviršiaus dažnai vadinamas „Preview Control“ (Dąbrowski, Ślaski 2016; Kitching et al. 1999). Šiam valdymo principui naudojami lazeriai, kameros, ultragarsiniai jutikliai. Dažniausiai šis valdymo principas pritaikomas aktyviai pakabai ir naudojamas norint pagerinti važiavimo komfortą (Valasek, Kortum 2002). Göhrle et al. (2015) panaudojo lazerinị jutiklį, sumontuotą ant priekinio stiklo, kuris matavo kelio nelygumus prieš automobiliui užvažiuojant ant matuojamo paviršiaus. Gautas signalas panaudotas pagerinti aktyvios pakabos amortizatorių darbą. Autoriai susidūrè su iššūkiais siekdami nustatyti automobilio amortizuotos masès svyravimus. Važiuojant per nelygumus svyruoja automobilio kẻbulas kartu su ant stiklo sumontuotu jutikliu. Kita problema - gaunamų signalų iš pagreičio jutiklių ir giroskopo filtravimas. Išmatuojami signalai labai triukšmingi.

Kitame darbe Bouzouraa et al. (2014) autoriai panaudojo kamerą, sumontuotą priekinio aušinimo skysčio radiatoriaus grotelių vietoje. Kamera fiksavo kelio paviršių trimačiu vaizdo formatu. Apdorotus signalus panaudojo aktyvios pakabos darbui pagerinti.

Mokslininkai publikacijoje (Ahmed; Svaricek 2014) aprašè kelio paviršiaus matavimą LIDAR (angl. Light Detection and Ranging) jutikliais. Transformavę signalus, kompensavo jutiklio montavimą ir gavo tikslesnị kelio paviršių. Autoriai panaudojo 7 laisvès laipsnių automobilio dinaminị modelị rezultatams simuliuoti ir atliko eksperimentinius bandymus su ketvirčio automobilio stendu. Atlikta rezultatų analizè parodè, kad šis valdymo principas važiavimo komfortu ir valdomumu yra pranašesnis už ,Skyhook“ ir „Groundhook“ pakabos valdymo principus, tačiau aprašomas ir šio valdymo principo sudètingumas.

Sugai et al. (2012) publikacijoje panaudojo „Preview Control“"valdymo principą aktyvioje pakaboje. Atlikti tyrimai parodè, kad pagerejo komfortas ir valdomumas visu svyravimų dažnių diapazonu, taip pat sumažejo sistemos el. energijos sąnaudos. 
Publikacijoje (Tudón-Martínez et al. 2014) pateikta kelio paviršiaus prognozè naudojant Furjè (angl. Fourier) analizę. Autoriai siekè apskaičiuoti kelio šiurkštumą ir gautus rezultatus palyginti su su ISO 8608 klasifikacija. Bandymų rezultatai parodè, kad pavyko sèkmingai identifikuoti daugiau kaip $70 \%$ kelio dangų su $5 \%$ paklaida.

Kitoks kelio paviršiaus prognozès metodas pasiūlytas K. Dąbrowskio ir G. Ślaskio darbe (Dąbrowski, Ślaski 2016). Metodas pagrịstas statistine pakabos darbo, virpesių analize. Panaudoję amortizuotos ir neamortizuotos masių pagreičio jutiklių signalus, autoriai galèjo prognozuoti kelio tipą.

\subsection{Kelio paviršiaus nelygumų nustatymo būdų apžvalga}

Donahue, Hedrick (2003) sukurta sistema pavadinta „Prognozuojantis valdymo modelis". Sistema sudaryta iš dviejų lazerių, kurie matavo atstumus iki kelio paviršiaus, o apdoroti duomenys panaudoti aktyvios pakabos darbui pagerinti. Šios sistemos trūkumai - naudojami du lazeriai, o jie pritvirtinti labai aukštai; sistema veikia, kai greitis nedidelis. Važiavimo komfortas padidejjo tris kartus. Ši sistema išbandyta JAV kariuomeneje.

Dar viena sukurta sistema (Fialho, Balas 2002) galima (žinant kelio nelygumus) keisti aktyvios pakabos veiklą pagerinant važiavimo komfortą. Pakaba reguliuojama dviem lygiais - parenkant pakabos charakteristikas, kai pasipriešinimo jèga minimali ir maksimali.

Automobilių gamintojo „Daimler AG“ sukurta ir užpatentuota sistema „Active Body Control“" (ABC) naudoja stereo kamerą kelio paviršiui skenuoti. Ši sistema skenuoja $15 \mathrm{~m}$ atstumu nuo automobilio priekio. Stereo kamera sudaryta iš dviejų dalių, išdėstytų $45^{\circ}$ kampu ir sumontuota ant priekinio stiklo. Stereo kameros suformuoja kelio paviršiaus trimati vaizdą. Kelio paviršiaus duomenys siunčiami ị valdymo bloką, išanalizuojami ir pateikiami aktyviai pakabos sistemai, kad galètų kaip įmanoma tolygiau pervažiuoti per nelygumus. Pakaba pagerina važiavimo komfortą, važiuojant per mažesnius nei $3 \mathrm{~mm}$ kelio nelygumus (Fleming 2014).

Panaši sistema suprojektuota (Schindler 2009) panaudojus anksčiau minètą ABC sistemą papildomai ant automobilio sumontavus du papildomus lazerinius jutiklius, skenuojančius kelio paviršių prieš automobilį.

Daugelyje sistemų naudojama aktyvi pakaba, kuri gali kompensuoti maždaug $0,5 \mathrm{~Hz}$ dažnio nelygumus, kai greitis $100 \mathrm{~km} / \mathrm{h}$. Jutikliai gali užfiksuoti nelygumus iki $55 \mathrm{~m}$ atstumu. Stereo kameroms ir lazeriniams jutikliams tokiu atstumu ma- 
tuoti kelio paviršių techniškai yra labai sudètinga. Siekiant dideliu dažniu ir atstumu matuoti kelio paviršių, naudojamas anksčiau užfiksuotų duomenų integracijos metodas (Bouzouraa et al. 2014).

Straipsnio autoriai (Kitching et al. 1999) sudarè pusiau aktyvios pakabos modelį ir jị išbandè HIL sistemoje. Pakabos modeliui iš anksto buvo nurodomas žinomas kelio profilis. Gauti pakabos svyravimų pagreičiai mažesni nuo $15 \%$ iki $18 \%$, atsižvelgiant i judejjimo greitị ir kelio profilį.

Yuan et al. (2015) aprašo būdą, kaip nustatyti kelio paviršiaus nelygumus, naudojant lazerinius linijų atpažinimo įrenginius. Straipsnyje aprašoma automobilio ir reljefo ịtaka matavimo tikslumui. Teigiama, kad naudojant ši metodą kelio paviršius turi būti švarus. Straipsnyje (Aki 2016) šis metodas pritaikomas sunkvežimių grupei. Pirmasis sunkvežimis kelio paviršių matuoja lazeriais ir gautus parametrus perduoda iš paskos važiuojantiems sunkvežimiams. Rezultatams apdoroti naudojamas „Naïve Bayes“ metodas (Martinez-Arroyo 2006).

Kitas būdas nustatyti kelio nelygumus - panaudoti automobilio pagreičio duomenis (O`brien et al. 2010; Harris et al. 2010). Automobilio judejjimo metu ịrašomi akcelerometro duomenys, jie optimizuojami ir pagal „Kryžminès entropijos“" (angl. The Cross Entropy) teoriją identifikuojami kelio nelygumai. Daugelis automobilių turi įmontuotus akcelerometrus, nes automobilio aktyviosios saugos sistemos naudoja lètėjimo, greitejjimo pagreičių reikšmes. Atliktas tyrimas su penkiomis kelio dangomis parodè, kad kelio paviršiaus prognoze iš pagreičio parametrų yra pakankamai tiksli (paklaida iki $\pm 2 \%$ ).

\subsection{Kelio nelygumų nustatymo metodai}

Šiame poskyryje apžvelgiami trys metodai, naudojami nustatyti kelio nelygumus. Visi metodai paremti atstumo iki kelio paviršiaus matavimu. Vienas iš metodų naudojamas Japonijos magistralinių kelių būklei įvertinti.

\subsubsection{Japonijoje naudojamas nustatymo metodas}

Japonijoje, siekiant nustatyti kelio nelygumus, naudojamas metodas matuojant aukščio skirtumus nuo kelio dangos (1.9 pav.). Matavimai atliekami kas 1,5 m trijuose taškuose. Bandymo metu duomenys įsimenami, o siekiant didesnio tikslumo, vietoj ritinèlių naudojami lazeriai (Souza et al. 2006). 


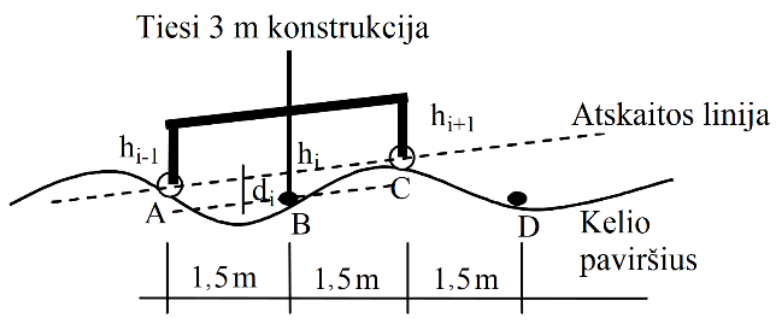

1.9 pav. Japonijoje naudojamas nelygumų matavimo metodas (Souza et al. 2006)

Fig. 1.9. The method of measuring road profile used in Japan (Souza et al. 2006)

Užfiksuoti matavimo rezultatai apdorojami naudojant formulę:

$$
d_{i}=h_{i}-\frac{1}{2}\left(h_{i-1}+h_{i+1}\right),
$$

čia $d_{i}$ - kelio profilio nelygumas; $h_{i}, h_{i-1}, h_{i+1}$ - charakteringuose taškuose matuojami atstumai.

Iš 1.9 paveikslo matyti, kad nustačius kelio profilio nelygumą $d_{i}$ taške $\mathrm{B}$, matavimo taškas perkeliamas i padètị $\mathrm{D}$, kur aukščiai $h_{i}, h_{i-1}, h_{i+1}$ atitinkamai yra taškuose B, C ir D. Atskaitos taškas tampa linija, einanti per taškus B, C ir D. Naudojant 1.21 formulę apskaičiuojamas $d_{i}$ taške C. Atliekant daug matavimų, gaunamos teigiamos ir neigiamos iškilimų reikšmès. Šie iškilimai yra aukščio skirtumai, atsižvelgiant $i$ atskaitos liniją kas $1,5 \mathrm{~m}$.

Standartinis išilginio nelygumo nuokrypis $\sigma$ yra apskaičiuojamas sumuojant kelio profilio aukščius $d_{i}$ pagal formulę:

$$
\sigma=\sqrt{\frac{n_{r} \sum d_{i}^{2}-\left(\sum d_{i}\right)^{2}}{n_{r}\left(n_{r}-1\right)}},
$$

čia $\sigma$-standartinis išilginio nelygumo nuokrypis; $d_{i}$ - kelio profilio nelygumas; $n_{r}-$ užfiksuotų duomenų skaičius.

Japonijos magistralinių kelių korporacija (Japan Highway Public Corporation) rekomenduoja koeficientą $\sigma$ apskaičiuoti iš $150 \mathrm{~m}$ ilgio kelio atkarpos užfiksuotų reikšmių.

\subsubsection{Simetrinis nustatymo metodas}

Dar du metodai kelio nelygumams nustatyti naudojant lazerinius jutiklius aprašyti šaltinyje Kilic, Hilsmann (2016). Pirmasis - simetrinis nustatymo metodas (1.10 pav., a). 


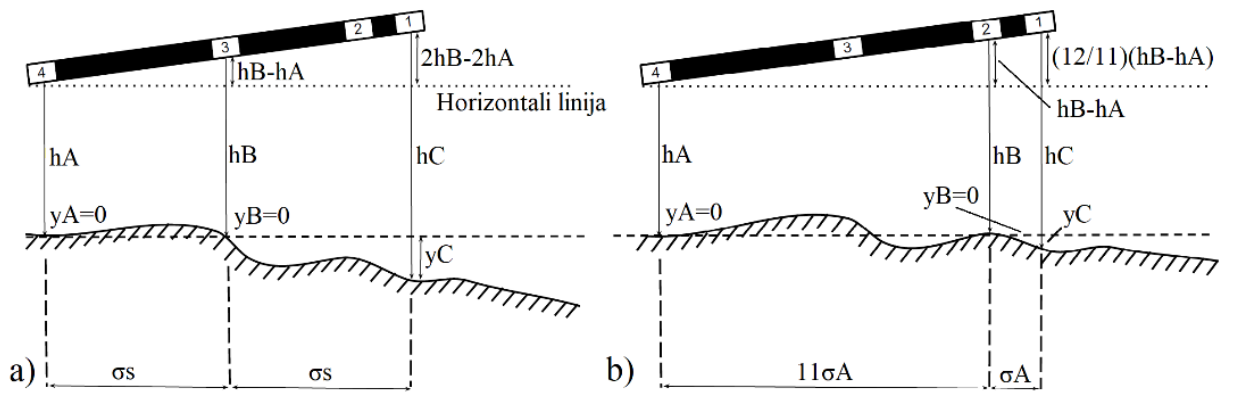

1.10 pav. Kelio nelygumų nustatymo metodai:

a) simetrinis, b) asimetrinis (Kilic, Hilsmann 2016)

Fig. 1.10. Methods for determining road roughness: a) symmetrical;

b) asymmetric (Kilic, Hilsmann 2016)

Šis nustatymo metodas patikimesnis matuojant trijų metrų ir ilgesnes kelio nelygumų bangas. Simetrinis būdas panašus ị anksčiau minètą japoniškajị, tačiau lazeriniai jutikliai išdèstyti $\sigma s=0,6 \mathrm{~m}$ atstumu. 1.10 a paveiksle lazeriniai atstumo jutikliai pavaizduoti numeriais 1, 3, 4. Užfiksavus jutiklių duomenis, nelygumas apskaičiuojamas pagal formules:

$$
\begin{gathered}
y_{n}=y_{n-1}+\sum_{i=1}^{n} U_{i}, \\
U=-\left(h_{1}-2 h_{3}+h_{4}\right),
\end{gathered}
$$

čia $y$ ir $U$ nurodo vidutini aukšti $\sigma s$ atstumu.

\subsubsection{Asimetrinis nustatymo metodas}

Asimetrinis nustatymo metodas yra naudojamas kaip pagalbinis būdas simetriniam metodui. Šis būdas skirtas nustatyti mažesnes kelio nelygumų bangas. Sistema naudoja taip pat tris lazerinius atstumo jutiklius, tik jie išdèstyti nesimetriškai (1.10 pav., b).

Atstumas tarp 1 ir 2 jutiklio yra $\sigma A=0,1 \mathrm{~m}$, atstumas tarp 2 ir 4 jutikliu $11 \sigma A=1,1 \mathrm{~m}$. Kiekvieno jutiklio fiksuojamos reikšmès naudojamos apskaičiuojant kelio nelygumo vidurkị pagal formules:

$$
\begin{gathered}
W=-\left(h_{1}-\frac{12}{11} h_{2}+\frac{1}{11} h_{4}\right), \\
y_{n}=\frac{12}{11} y_{n-1}+\frac{1}{11} y_{n-12}+W_{n},
\end{gathered}
$$


čia $y$ ir $W$ nurodo vidutinị aukštį ir matavimo parametrus $\sigma A$ atstumu.

Pristatyti kelio nelygumų nustatymo metodai apsiriboja lazerinių jutiklių signalų apdorojimu, tačiau jutiklius montuojant prie automobilio svarbu ịvertinti jo kejbulo inertiškumą ir sukeliamus svyravimus.

\subsection{Moksliniuose darbuose naudojamų matematinių modelių apžvalga ir pritaikymo galimybès}

Teoriniams tyrimams naudojamos ịvairios kompiuterinès programos, kuriomis sukurtam matematiniam modeliui išbandyti reikia mažesnių išteklių, o bandymų kiekis neribotas. Sukurtą matematini modeli reikia validuoti eksperimentiniais bandymais, tuomet sudètingi teoriniai tyrimai atitinka realybejje galiojančius fizikinius dèsnius. Tokia seka tyrimai atliekami ir šiame darbe:

- pirmiausia atliekama literatūros apžvalga, norint išsiaiškinti, kokie matematiniai modeliai naudojami moksliniuose darbuose, susijusiuose su pakabomis;

- parenkamas standartinis matematinis modelis;

- matematinis modelis koreguojamas pagal darbe nagrinèjamą problemą;

- atliekami eksperimentiniai tyrimai modeliui validuoti;

- atliekami teoriniai tyrimai su patikrintu modeliu.

Atlikdami teorinius tyrimus mokslininkai naudoja ịvairius matematinius modelius. Dažniausiai pasitaikantys - ketvirčio, pusès, viso automobilio matematiniai modeliai. 1.2 lenteleje pateikta analizè, kokius matematinius modelius naudoja autoriai, atlikdami teorinius pusiau aktyvios pakabos tyrimus.

1.2 lentelè. Matematiniai modeliai, naudojami nagrinejjant pusiau aktyvią pakabą Table 1.2. Mathematical models used for analysis of semi-active suspension

\begin{tabular}{|c|l|}
\hline Naudojamas modelis & \multicolumn{1}{c|}{ Šaltiniai } \\
\hline 1 & \multicolumn{1}{c|}{2} \\
\hline ketvirčio automobilio & $\begin{array}{l}\text { Dutta 2017; Aubouet } \text { et al. 2008; Liu } \text { et al. 2005; Rao } \text { et al. } \\
\text { 2010; Hong } \text { et al. 2002; Sammier } \text { et al. 2003; Kashem } \text { et al. }\end{array}$ \\
& 2015; Flores et al. 2006; Valasek, Kortum 2002; Flores \\
& et al. 2006; Hac, Youn 1992; Takaba 2003; Huisman et al. \\
& 1993; Kashem et al. 2015; Emam, Ghany 2012; Suzuki, \\
& Takahashi 2012; Sohn et al. 2000; Savaresi, Spelta 2009; \\
& Pei et al. 2016, Kashem et al. 2015; Tawwab 2013 \\
\hline
\end{tabular}


1.2 lentelès pabaiga

\begin{tabular}{|l|l|}
\hline \multicolumn{1}{|c|}{1} & \multicolumn{1}{|c|}{2} \\
\hline $\begin{array}{l}\text { pusės automobilio } \\
\text { (išilginis) }\end{array}$ & $\begin{array}{l}\text { Krauze, Kasprzyk 2016a; Shamsi, Choupani 2008; } \\
\text { Kitching } \text { et al. } \text { 1999; Ahmed, Svaricek 2013; Huisman } \\
\text { et al. 1993; Canale } \text { et al. 2002; Ahmed, Svaricek 2013; } \\
\text { Marzbanrad } \text { et al. 2013 }\end{array}$ \\
\hline viso automobilio & $\begin{array}{l}\text { Çalışkan } \text { et al. 2016; Ahmed, Svaricek 2014, Žuraulis, So- } \\
\text { kolovskij 2018 }\end{array}$ \\
\hline
\end{tabular}

Iš 1.2 lentelès matyti, kad pakabai nagrinèti dažniausiai naudojamas ketvirčio automobilio dinaminis modelis. Šis modelis leidžia nagrinèti automobilio dinamiką, neatsižvelgiant ị pakabos tipą. Modelyje aprašomos nedeformuojamos masès atitinka elementus, kurie sudaro ratą, pakabos elementus ir kitas važiuoklès dalis, sąveikaujančias su keliu, taip pat amortizuotą masę - automobilio kèbulą. Ketvirčio automobilio modeliu gauti rezultatai lyginami su eksperimentiniais rezultatais, gautais ketvirčio automobilio stendais.

Norint tyrinèti pakabos poveikị amortizuotai masei, itraukiant sukimosi apie skersinę ašį kampą, ketvirčio automobilio dinaminį modelį reikia išplèsti iki pusès automobilio dinaminio modelio. Šio tipo modeliai būna dviejų tipų: išilginei ir skersinei automobilio dinamikai nagrinèti. Pakabų tyrimams svarbiau nagrinèti ne tik priekinius automobilio ratus su pakabos elementais, bet ir galinius. Tad matematiniam modeliavimui pasirinktas pusès automobilio išilginis dinaminis modelis.

\subsection{Automobilį veikiantys virpesiai ir jų nustatymo būdai}

Realiomis sąlygomis visos mechaninès sistemos yra slopinamos (Bogdevičius et al. 2012; Žuraulis; Levulytė 2014). Automobilių pakaboje montuojami amortizatoriai, kurie pagal automobilio tipą, jo svorị projektuojami su savita dinamiškai kintančia slopinimo reikšme (Bogdevičius et al. 2016). Pagal svyravimų dažnị virpesiai skirstomi ị tris grupes (Chen et al. 2016):

- ypač žemo dažnio - nuo 0 iki $15 \mathrm{~Hz}$;

- žemo dažnio - nuo $15 \mathrm{~Hz}$ iki $150 \mathrm{~Hz}$;

- aukšto dažnio - daugiau nei $150 \mathrm{~Hz}$.

Tam tikro dažnio virpesiai yra pavojingi žmonèms. Ypač pavojingi virpesiai, kurie yra artimi žmogaus kūno dalių savajam dažniui. Transporto priemonèse, sie- 
kiant didesnio vairuotojų ir keleivių komforto, virpesių dažnis yra žemas ir priklauso ypač žemo dažnio grupei. Pagal ISO 2631 standartą vibracijos dažniai transporto priemonèse gali būti suskirstyti ị keturias grupes (Ślaski 2011):

- kẻbulo rezonansinị piko dažnị - nuo 1 iki $2 \mathrm{~Hz}$;

- kẻbulo ir ratų rezonansini piko dažni - nuo 5 iki $6 \mathrm{~Hz}$;

- ratų rezonansini piko dažni - apie $10 \mathrm{~Hz}$;

- didesnị nei ratų rezonansinị piko dažnį - apie $16 \mathrm{~Hz}$.

Amortizuotos masès virpesiams ịvertinti naudojami ịvairūs rodikliai. Vieni iš populiariausių - vidutinis kvadratinis nuokrypis (RMS) ir virpesių dalies vertė (VDV). Šiuos rodiklius publikacijose naudoja daug pasaulio mokslininkų - Yinlong et al. 2017; Ihsan et al. 2009; Abramov et al. 2009; Ploechl, Mastinu 2014; Sande et al. 2016; Canale et al. 2006; Koulocheris et al. 2017; Wang et al. 2018 ir kiti.

RMS reikšmè skaičiuojama amortizuotai masei. Gaunamas vienas rodiklis pagal formulę:

$$
\ddot{z}_{M_{R M S}}=\left(\frac{1}{T} \int_{0}^{T} \ddot{z}_{M}^{2}(t) d t\right)^{1 / 2},
$$

čia $\ddot{z}_{M}(t)$ - amortizuotos masès pagreitis kaip funkcija nuo laiko, $T$ - matavimo periodas. RMS rodiklis komfortui ịvertinti.

VDV parametras įvertina vidutinę signalo reikšmę ir poveikio trukmę. Pagal Didžiosios Britanijos standartą BS 6841, kai VDV parametras pasiekia $15 \mathrm{~ms}^{(-1,75)}$, važiavimo komfortas yra labai blogas (Bogdevičius 2012).

$$
V D V=\left(\int_{0}^{T} \ddot{z}_{w}^{4}(t) d t\right)^{1 / 4},
$$

čia $\ddot{z}_{w}(t)$ - vertikalus pagreitis su svorio koeficientu, jis apskaičiuojamas pagal formulę:

$$
\ddot{z}_{w}(t)=c(f) \cdot \ddot{z}_{M}(t),
$$

$c(f)$ svorio koeficientai parenkami pagal dažnio rodiklius:

$$
c(f)= \begin{cases}0,4 ; & \text { kai } 0,5<f<2 \mathrm{~Hz}, \\ f / 5,0 ; & \text { kai } 2<f<5 \mathrm{~Hz}, \\ 1 ; & \text { kai } 5<f<16 \mathrm{~Hz}, \\ 16 / f ; & \text { kai } 16<f<80 \mathrm{~Hz} .\end{cases}
$$




\subsection{Tarptautinis kelio nelygumo indeksas}

Kelio dangos lygumas yra vienas iš pagrindinių kelio kokybės rodiklių (Sivilevičius et al. 2017), darančių ịtaką eismo saugumui ir važiavimo komfortui. Kelio nelygumai taip pat turi įtakos padangos ir rato tarpusavio sąveikai (Celko et al. 2009). Nelygumas - tai nukrypimų nuo idealaus išilginio profilio suma, išreikšta metrais kilometrui. Kelio lygumas tiesiogiai priklauso nuo dangos defektų kiekio ir dydžio (duobių, lopų, skersinių, išilginių, tinklinių plyšių, bangų ir t. t.) (Paukštė 2015).

Kelio lygumui ịvertinti naudojamas tarptautinis kelio nelygumo indeksas (International Roughness Index (IRI)) (Sivilevičius, Vansauskas 2013; Prashant et al. 2018; ISO 8608; ASTM E1926-08 2015). IRI - tarptautinis nelygumo indeksas, ịvertinantis nelygumus - jų dydị ir išdèstymą, tenkantị kelio dangos ilgio vienetui. 1.3 lentelèje pateiktas IRI indeksas ịvairioms kelio dangoms.

Knygoje „The Little Book of Profiling“ yra pateikta informacija apie kelio nelygumu IRI indekso atitikmenį kelio dangoms (1.11 pav.). Paveiksle taip pat matyti rekomenduojami greičiai važiuojant skirtingomis dangomis.

1.3 lentelè. Tarptautinio nelygumo indekso ribos kelio dangoms (Pakalnis, Dimaitis 2001)

Table 1.3. International roughness index limits for road pavements (Pakalnis, Dimaitis 2001)

\begin{tabular}{|c|c|c|c|c|c|}
\hline $\begin{array}{l}\text { Kelio dangos } \\
\text { nelygumo }\end{array}$ & \multicolumn{5}{|c|}{ Kelio nelygumo dangos vertinimas } \\
\hline $\begin{array}{c}\text { Naujai ịrengta } \\
\text { danga }\end{array}$ & geras & \multicolumn{2}{|c|}{ patenkinamas } & \multicolumn{2}{|c|}{ nepatenkinamas } \\
\hline $\begin{array}{l}\text { Magistralinis } \\
\text { kelias }\end{array}$ & $\leq 1,5 \mathrm{~m} / \mathrm{km}$ & \multicolumn{2}{|c|}{$1,5-2,5 \mathrm{~m} / \mathrm{km}$} & \multicolumn{2}{|r|}{$\geq 2,5 \mathrm{~m} / \mathrm{km}$} \\
\hline $\begin{array}{l}\text { Eksploatuo- } \\
\text { jama danga }\end{array}$ & l. geras & geras & pat & & $\begin{array}{c}\text { nepatenkina- } \\
\text { mas }\end{array}$ \\
\hline $\begin{array}{l}\text { AM ir AI kate- } \\
\text { gorijų magistra- } \\
\text { linis kelias }\end{array}$ & $\leq 1,0 \mathrm{~m} / \mathrm{km}$ & $1,0-2,0 \mathrm{~m} / \mathrm{km}$ & $2,0-$ & & $\geq 3,0 \mathrm{~m} / \mathrm{km}$ \\
\hline $\begin{array}{l}\text { Magistralinis } \\
\text { kelias }\end{array}$ & $\leq 1,5 \mathrm{~m} / \mathrm{km}$ & $1,5-2,5 \mathrm{~m} / \mathrm{km}$ & $2,5-$ & & $\geq 3,5 \mathrm{~m} / \mathrm{km}$ \\
\hline
\end{tabular}




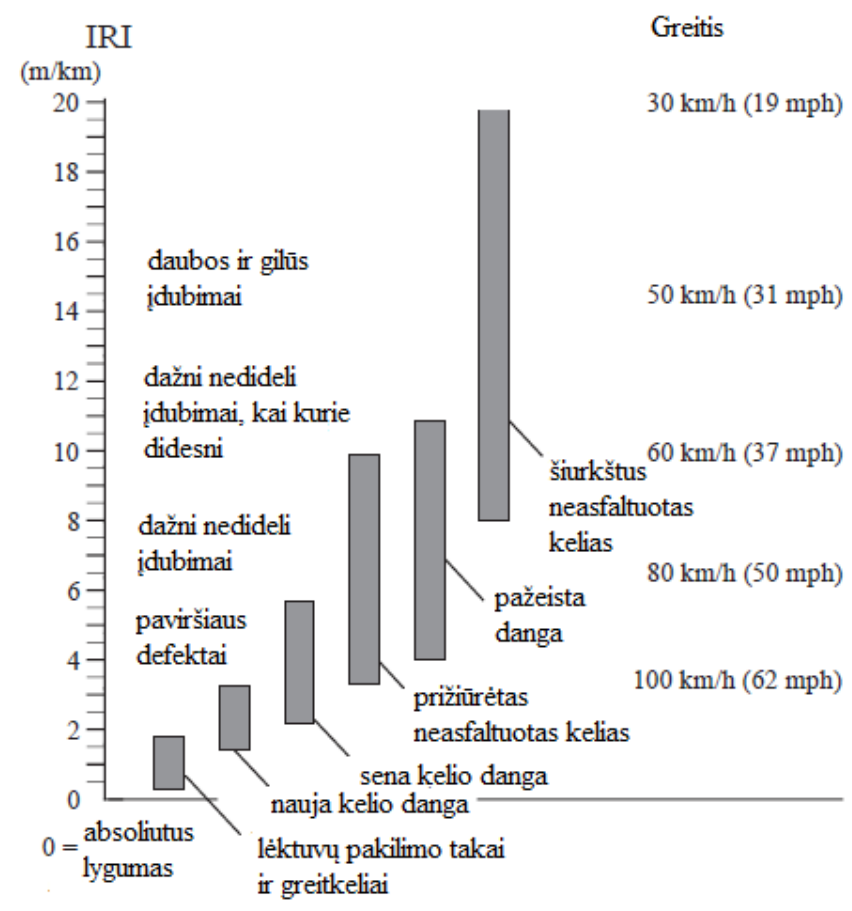

1.11 pav. Tarptautinio nelygumo indekso priklausomybė nuo skirtingų kelio tipu (Sayers 1998)

Fig. 1.11. International roughness index dependence of different road classes

(Sayers 1998)

Iš 1.11 paveikslo matyti, kad IRI indeksas yra mažiausias lëktuvų pakilimo takams ir greitkeliams. Ši kelio danga pritaikyta didesniam nei $100 \mathrm{~km} / \mathrm{h}$ greičiui. Didžiausią reikšmę turi šiurkštus neasfaltuotas kelias, kuriuo judejjimo greitis yra $60 \mathrm{~km} / \mathrm{h}$ ir mažesnis.

\subsection{Teorinių ir eksperimentinių tyrimụ prielaidos}

Šiame darbe atliekant teorinius ir eksperimentinius tyrimus daromos šios prielaidos:

- Teoriniuose tyrimuose naudojamas pusès automobilio matematinis modelis, atlikus validaciją, atitinka realiai važiuojančio automobilio dinamiką. 
- Matematiniame modelyje ratas aprašomas kaip taškas, judantis per nustatyto dyžio nelygumą.

- Teoriniuose ir eksperimentiniuose tyrimuose automobilis juda pastoviu greičiu.

- Teoriniuose tyrimuose naudojamų pusiau aktyvių amortizatorių pasipriešinimo jègai pakeisti užtrunka $0,073 \mathrm{~s}$.

- Automobilis, naudojantis kelio nelygumų nustatymo sistemą ir pusiau aktyvius amortizatorius, gali judèti maksimaliu 13,7 m/s greičiu, kai dar imanoma pakeisti norimas pasipriešinimo jègas.

- Teoriniuose tyrimuose automobilis juda per pusès sinusoidès formos kelio nelygumus: 1 - aukštis $0,05 \mathrm{~m}$, ilgis $0,35 \mathrm{~m} ; 2$ - aukštis $0,1 \mathrm{~m}$, ilgis $0,35 \mathrm{~m}$.

\subsection{Pirmojo skyriaus išvados ir disertacijos uždavinių formulavimas}

1. Automobilių gamintojų naudojamas pusiau aktyvios pakabos valdymo principas „Skyhook“ sumažina amortizuotos masès svyravimų trukmę ir amplitudę. Neamortizuotos masès svyravimų trukmè ir amplitudè gali būti didesnè lyginant su automobilio pasyvia pakaba.

2. Kelio paviršiaus nelygumams nustatyti naudojamos trimačio vaizdo kameros, ultragarsiniai jutikliai, lazeriniai linijų identifikavimo jutikliai, pagreičio jutikliai. Lazeriniai atstumo jutikliai gali būti naudojami kelio profiliui identifikuoti.

3. Tiksliam kelio paviršiui nustatyti, jei jutiklis pritvirtintas prie amortizuotos masès, reikia kompensuoti momentinius svyravimus, atsirandančius dèl pakabos ir ratų deformacijų.

4. Automobilių pakabai nagrinèti dažniausiai naudojamas ketvirčio automobilio dinaminis modelis. Norint tyrinèti pakabos poveikị amortizuotai masei, ịtraukiant sukimosi apie skersinę ašị kampą, ketvirčio automobilio dinaminị modelị reikia išplèsti iki pusès automobilio dinaminio modelio.

5. Žmogui pavojingi virpesiai, kurie yra artimi žmogaus kūno dalių savajam dažniui. Transporto priemonėse, siekiant didesnio vairuotojų ir keleivių komforto, virpesių dažnis yra žemas ir priklauso ypač žemo dažnio grupei. 
Atlikus literatūros analizę buvo suformuluoti pagrindiniai darbo uždaviniai:

1. Išanalizuoti pusiau aktyvių amortizatorių valdymo metodus ir kelio nelygumų nustatymo būdus.

2. Patikslinti išilginị pusès automobilio matematinị modelị, veikiantị su standumo ir slopinimo elementų netiesinėmis charakteristikomis, amortizatorių uždelsimu, ir galimybę nustatyti kelio nelygumus.

3. Sukurti kompensavimo algoritmą kelio paviršiaus nelygumui nustatyti automobiliui važiuojant pastoviu greičiu.

4. Panaudojant gautą informaciją apie kelio nelygumus ir patobulinus pusiau aktyvios pakabos valdymo algoritmus, sumažinti automobilio vertikaliuosius svyravimus (automobilių pusiau aktyvios pakabos valdymo tobulinimas).

5. Parinkti racionalią lazerinio atstumo jutiklio montavimo vietą, tinkančią kelio profiliui nustatyti prieš ratui užvažiuojant ant nelygumo.

6. Eksperimentiškai ištirti ir palyginti važiuojančio automobilio, su žinomu ir patobulintu pusiau aktyvios pakabos valdymo algoritmu, dinaminius parametrus. 


\section{2}

\section{Lengvojo automobilio su pusiau aktyvia pakaba ir kelio nelygumų nustatymo sistema dinaminių savybių skaitinė analizè}

Skyriuje pateikiamas patobulintas pusès automobilio su sumontuotu lazeriniu atstumo jutikliu matematinis modelis. Pristatomas svyravimų kompensavimo modelis, analizuojami matematiniu modeliavimu gauti rezultatai. Skyriaus pabaigoje aprašyti pusiau aktyvios pakabos su nelygumų nustatymu valdymo algoritmai. Pateikti rezultatai lyginami su pasyvia pakaba ir „Skyhook" valdymo principu.

Skyriaus tematika paskelbtos keturios publikacijos (Surblys et al. 2018; Surblys, Sokolovskij 2018; Surblys et al. 2019; Mužar et al. 2018).

\subsection{Automobilio su sumontuotu lazeriniu atstumo jutikliu matematinis modelis}

Atlikus 1.6 poskyryje pateiktą matematinių modelių apžvalgą, pasirinktas pusès automobilio matematinis modelis (Savaresi et al. 2010). Modelis autoriaus papildytas sprendžiamai problemai nagrinèti - atstumu $l_{l}$ pritvirtintas lazerinis atstumo 
jutiklis (2.1 pav.). Lazerinis jutiklis nukreiptas ị kelio paviršių $90^{\circ}$ kampu. Duomenys, naudoti matematiniam modeliavimui, pateikti 2.1 lentelèje. Pasirinktos reikšmès atitinka „Opel Astra“ automobilio parametrus, nes šis automobilis naudotas eksperimentiniuose bandymuose. Automobilio duomenys paimti iš programinès įrangos PC Crash 8.1, skirtos eismo ịvykiams tirti. Šiame modelyje jutiklio montavimo vieta pasirinkta 1 metro atstumu ị priekị nuo priekinès ašies. Toks atstumas pasirinktas dèl tipiškos lengvojo automobilio konstrukcijos, kai priekinè iškiša siekia $0,7-1,1 \mathrm{~m}$. Eksperimentiniuose tyrimuose naudotų automobilių priekinès iškišos yra $0,7-0,96 \mathrm{~m}$. Montavimo elementais lazerinis jutiklis pritvirtintas 1 metro atstumu nuo priekinès ašies. Lazerinio jutiklio montavimo padètis - statmena kelio paviršiui nejudant automobiliui.

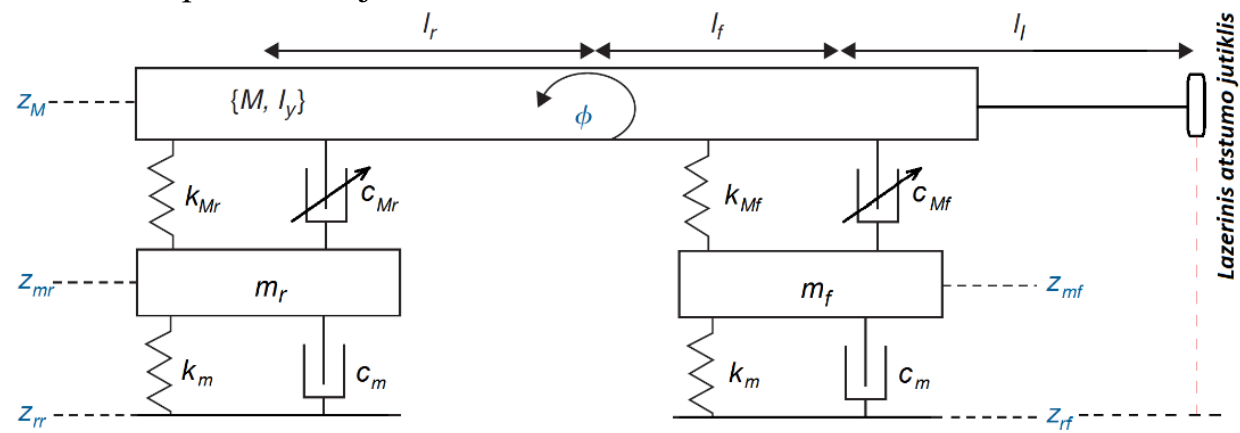

2.1 pav. Pusès automobilio modelis su sukimu apie skersinę aši ir sumontuotu lazeriniu atstumo jutikliu

Fig. 2.1. Pitch oriented "half-car" model with mounted laser sensor

Pusès automobilio modelis sudarytas iš trijų masių: $M$ - transporto priemonès kèbulas (amortizuota masè), $m_{f}$ ir $m_{r}$ - priekinis ir galinis ratai su pritvirtintais pakabos elementais (neamortizuotos masès). Šis modelis turi 4 laisvès laipsnius: vertikalus amortizuotos masès poslinkis $z_{M}$ ir sukimas apie skersinę aši $\varphi$, vertikalūs neamortizuotų masių poslinkiai $z_{m r}$ ir $z_{m f}$.

Nepriklausomas kelio žadinimas pažymètas kaip kelio poslinkis ị priekinị ir galinị ratus $z_{r r}$ ir $z_{r f}$. Atstumas nuo kelio paviršiaus iki lazerinio atstumo jutiklio pažymètas $z_{l}$.

Modelyje ratas pateiktas kaip elementas, turintis standumo koeficientą $k_{m}$ ir pasipriešinimo koeficientą $c_{m}$. Modelyje šie dydžiai naudojami kaip konstantos. 2.2 formulëje pateiktos sąlygos leidžia ratui atitrūkti nuo kelio paviršiaus.

Pakabos standumo $\left(k_{M f}, k_{M r}\right)$ ir pasipriešinimo $\left(c_{M f}, c_{M r}\right)$ koeficientai dažniausiai literatūroje tokio tipo modeliuose aprašomos linijine funkcija, tačiau 
šiame darbe, siekiant gauti tikslesni modeli, šie elementai yra aprašyti netiesinèmis funkcijomis. Standumo ir slopinimo elementų charakteristikos pateiktos 2.2 poskyryje.

2.1 lentelė. Tyrimams naudoto automobilio „Opel Astra“ parametrų reikšmės

Table 2.1. Parameters of vehicle Opel Astra used in simulations

\begin{tabular}{|l|l|}
\hline \multicolumn{1}{|c|}{ Parametras } & Reikšmé \\
\hline Pusės automobilio kèbulo mase் $M, \mathrm{~kg}$ & 814 \\
\hline Priekinè neamortizuota mase் $m_{f}, \mathrm{~kg}$ & 45 \\
\hline Galinè neamortizuota mase் $m_{r}, \mathrm{~kg}$ & 35 \\
\hline Padangos standumo koeficientas $k_{m}, \mathrm{~N} / \mathrm{m}$ & 182000 \\
\hline Padangos slopinimo koeficientas $c_{m}, \mathrm{~N} \cdot \mathrm{s} / \mathrm{m}$ & 200 \\
\hline Automobilio ratu bazè $w b, \mathrm{~m}$ & 2,61 \\
\hline Atstumas nuo svorio centro iki priekinès automobilio ašies $l_{f}, \mathrm{~m}$ & 1,30 \\
\hline Atstumas nuo svorio centro iki galinės automobilio ašies $l_{r}, \mathrm{~m}$ & 1,31 \\
\hline Atstumas nuo priekinės ašies iki lazerinio jutiklio montavimo vietos $l_{l}, \mathrm{~m}$ & 1 \\
\hline Ašinis inercijos momentas $I_{y}, \mathrm{~kg} \cdot \mathrm{m}^{2}$ & 948,75 \\
\hline
\end{tabular}

Išilginis pusės automobilio matematinis modelis yra apibrèžiamas šiomis lygtimis:

$$
\left\{\begin{array}{l}
M \ddot{z}_{M}=-\left[F_{k M f}\left(\Delta z_{f}\right)+F_{0 k f}\right]-\left[F_{k M r}\left(\Delta z_{r}\right)+F_{0 k r}\right]-F_{c M f}\left(\Delta \dot{z}_{f}\right)-F_{c M r}\left(\Delta \dot{z}_{r}\right), \\
I_{y} \ddot{\varphi}=-l_{f}\left(\left[F_{k M f}\left(\Delta z_{f}\right)+F_{0 k f}\right]+F_{c M f}\left(\Delta \dot{z}_{f}\right)\right)+l_{r}\left(\left[F_{k M r}\left(\Delta z_{r}\right)+F_{0 k r}\right]+F_{c M f}\left(\Delta \dot{z}_{f}\right)\right), \\
m_{f} \ddot{z}_{m f}=\left[F_{k M f}\left(\Delta z_{f}\right)+F_{0 k f}\right]-F_{k m f}+F_{c M f}\left(\Delta \dot{z}_{f}\right)-F_{c m f}, \\
m_{r} \ddot{z}_{m r}=\left[F_{k M r}\left(\Delta z_{r}\right)+F_{0 k r}\right]-F_{k m r}+F_{c M r}\left(\Delta \dot{z}_{r}\right)-F_{c m r},
\end{array}\right.
$$

čia $F_{k M f}, F_{k M r}$ - priekinès ir galinès spyruoklių standumo jègos, aprašytos 2.2 poskyryje; $F_{0 k f}, F_{0 k r}$ - priekinès ir galinès spyruoklių ịveržimo jègos, aprašytos 2.2 poskyryje; $F_{c M f}, F_{c M r}$ - priekinès ir galinès amortizatorių slopinimo jègos, aprašytos 2.9 lygtimis; $F_{k m f}, F_{k m r}, F_{c m f}, F_{c m r}$ - priekinės ir galinės padangos 
standumo ir slopinimo jëgos, apskaičiuojamos 2.2 formule; $\Delta z_{f}, \Delta z_{r}$-priekinès ir galinès pakabos eigos poslinkiai vertikalia kryptimi, skaičiuojami pagal 2.3 formules; $\Delta \dot{z}_{f}, \Delta \dot{z}_{r}$-priekinès ir galinès pakabos eigos greičiai vertikalia kryptimi, skaičiuojami pagal 2.4 formules.

$$
\left\{\begin{array}{l}
F_{k m f}=k_{m}\left(z_{m f}-z_{r f}\right) \cdot H\left(z_{m f}-z_{r f}\right), \\
F_{c m f}=c_{m}\left(\dot{z}_{m f}-\dot{z}_{r f}\right) \cdot H\left(z_{m f}-z_{r f}\right), \\
F_{k m r}=k_{m}\left(z_{m r}-z_{r r}\right) \cdot H\left(z_{m r}-z_{r r}\right), \\
F_{c m r}=c_{m}\left(\dot{z}_{m r}-\dot{z}_{r r}\right) \cdot H\left(z_{m r}-z_{r r}\right),
\end{array}\right.
$$

čia $H$ - Hevisaido vienetiné funkcija (Bottega 2006).

$$
\begin{gathered}
\left\{\begin{array}{l}
\Delta z_{f}=z_{M}+l_{f} \sin \varphi-z_{m f}, \\
\Delta z_{r}=z_{M}+l_{r} \sin \varphi-z_{m r} .
\end{array}\right. \\
\left\{\begin{array}{l}
\Delta \dot{z}_{f}=\dot{z}_{M}+l_{f} \dot{\varphi} \cos \varphi-\dot{z}_{m f}, \\
\Delta \dot{z}_{r}=\dot{z}_{M}+l_{r} \dot{\varphi} \cos \varphi-\dot{z}_{m r} .
\end{array}\right.
\end{gathered}
$$

Atstumas nuo lazerinio jutiklio iki kelio dangos skaičiuojamas pagal:

$$
z_{l}=z_{l 0}(t=0)+z_{M}+\left(l_{f}+l_{l}\right) \sin \varphi
$$

čia $z_{l 0}$-atstumas nuo jutiklio iki kelio paviršiaus, kai $t=0$.

Pateiktas 2.1 paveiksle matematinis modelis sudarytas Matlab/Simulink aplinkoje (2.2 pav.). Programos Matlab kodas, naudotas ịvesti modeliui pradinius duomenis, pateiktas A priede.

Naudota programinè ịranga Matlab/Simulink suteikia labai daug galimybių, todèl yra dažnai pasirenkama specializuotuose tyrimuose. Viena svarbiausių funkcijų - pasirinkti integravimo būdą ir duomenų fiksavimo dažnį. Darbe atlikti skaičiavimai naudojant Eulerio skaičiavimo metodą ir $500 \mathrm{~Hz}$ dažnị. Šis dažnis pasirinktas, nes eksperimentiniuose bandymuose naudota ịranga duomenis fiksuoja tuo pačiu dažniu.

Visi teorinių tyrimų rezultatai išvedami skaitinėmis reikšmėmis, vẻliau apdorojami Matlab papildiniais Curve Fitting, Signal Analysis. Grafiškai rezultatai pateikiami panaudojant minètos programos papildinị Figures. 


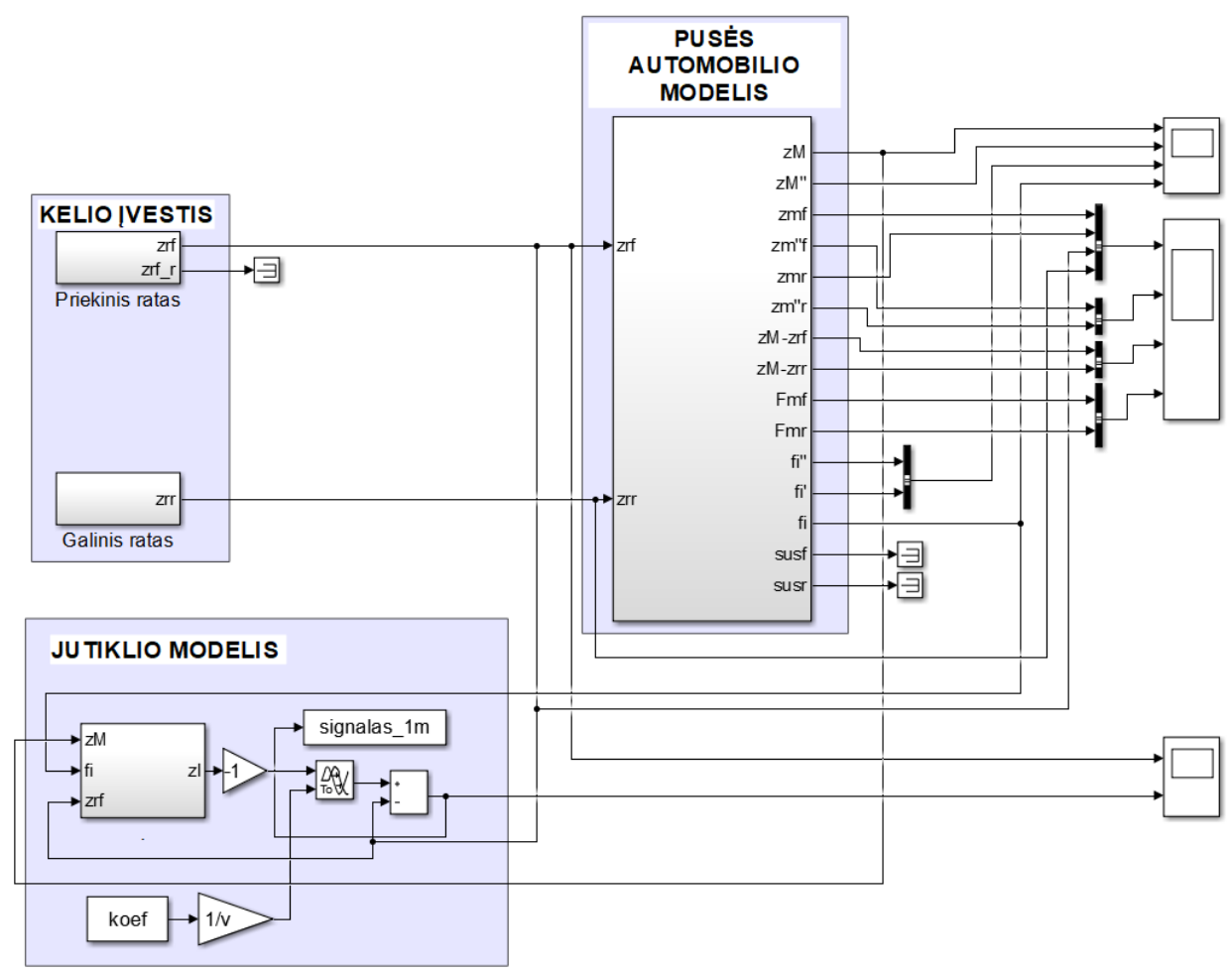

2.2 pav. Pusès automobilio modelis Matlab/Simulink aplinkoje

Fig. 2.2. "Half-car" model in Matlab/Simulink environment

Matlab programinè ịranga skirta kurti matematinius modelius panaudojant blokines schemas. Kiekvienas ženklas, funkcija ar kintamasis nurodomas iš bibliotekos pasirenkant atitinkamą simbolị. Sujungta blokų visumą veikia kaip matematinè sistema. İvedus pradinius duomenis, atliekama modelio simuliacija.

\subsection{Standumo ir slopinimo elementų charakteristikų netiesiškumas}

Daug pasaulio mokslininkų, nagrinėdami automobilių dinamiką, naudoja paprastus matematinius modelius, kuriais nevertinama slopinimo ir standumo elementuc jègų kitimas. Tokiuose modeliuose amortizatorių, spyruoklių suspaudimas ir pailgejimas sukuria lygiai tokią pačią jègą, bet priešingų krypčių. Taip pat spyruoklès sukuriama standumo jèga tolygiai kinta, keičiantis pakabos eigai, o amortizatoriaus pasipriešinimo jèga tolygiai kinta, keičiantis pakabos greičiui. Tačiau realūs 
amortizatoriai ir spyruoklès turi kintančias charakteristikas. Matematiniame modelyje, norint atkartoti realių pakabų darbą, tikslinga naudoti slopinimo ir standumo elementų charakteristikų netiesiškumą.

Matematiniame modelyje pasirinktos realios amortizatorių ir spyruoklių charakteristikos. Šios spyruoklès ir amortizatoriai buvo naudoti taip pat ir eksperimentiniuose bandymuose. Charakteristikos gautos išmatavus priklausomybes stendiniais bandymais ir išsamiai aprašytos šaltiniuose Więckowski et al. 2018, Ślaski 2010 (amortizatorių charakteristikos) ir Pikosz, Ślaski 2010 (spyruoklių charakteristikos).

2.3 paveiksle pateiktos priekinès ir galinès spyruoklių standumo jègų charakteristikos. Priekinès pakabos eiga yra $0,15 \mathrm{~m}$, o galinès $-0,2 \mathrm{~m}$. Priekinès pakabos pradinis įveržimas pasirinktas $0,078 \mathrm{~m}$, galinès pakabos $-0,12 \mathrm{~m}$. Duomenys pasirinkti automobilio masei su vienu žmogumi (Pikosz, Ślaski 2010). Charakteristikos labai panašios ị tiesiškai kintančias, tik priekinès spyruoklès sukuriama jèga sparčiai didèja pasiekus $0,07 \mathrm{~m}$ suspaudimą ir atsiradus maždaug $0,05 \mathrm{~m}$ pailgèjimui.

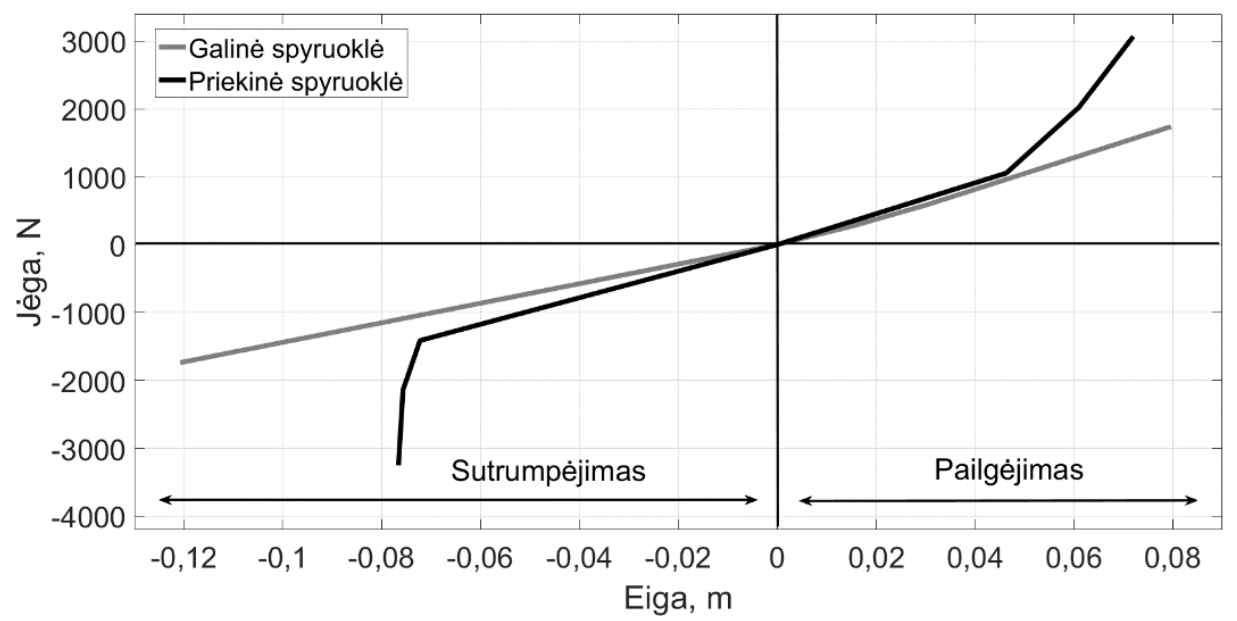

2.3 pav. Priekinès ir galinès spyruoklių netiesinès standumo charakteristikos

(Pikosz, Ślaski 2010)

Fig. 2.3. Front and rear springs non-linear stiffness characteristics

(Pikosz, Ślaski 2010)

Priekinès spyruoklès standumo jègų kitimą $F_{k M f}\left(\Delta z_{f}\right)$ aprašo penkto laipsnio daugianario funkcija: 


$$
\begin{aligned}
& F_{k M f}\left(\Delta z_{f}\right)=1,562 \cdot 10^{9} \cdot \Delta z_{f}{ }^{5}-5,871 \cdot 10^{8} \cdot \Delta z_{f}{ }^{4}+8,182 \cdot 10^{7} \cdot \Delta z_{f}{ }^{3}- \\
& 5,073 \cdot 10^{6} \cdot \Delta z_{f}{ }^{2}+1,527 \cdot 10^{5} \cdot \Delta z_{f}+1017,
\end{aligned}
$$

čia $\Delta z_{f}$ ir $F_{k M f}\left(\Delta z_{f}\right)-2.3$ paveiksle horizontalioje ir vertikalioje ašyse esančios reikšmès.

Galinès spyruoklès standumo jègų kitimą $F_{k M r}\left(\Delta z_{r}\right)$ aprašo trečio laipsnio daugianario funkcija:

$$
\begin{aligned}
& F_{k M r}\left(\Delta z_{r}\right)=1,644 \cdot 10^{5} \cdot \Delta z_{r}{ }^{3}-1,017 \cdot 10^{4} \cdot \Delta z_{r}{ }^{2}+ \\
& 1,794 \cdot 10^{4} \cdot \Delta z_{r}+6,514,
\end{aligned}
$$

čia $\Delta z_{r}$ ir $F_{k M r}\left(\Delta z_{r}\right)-2.3$ paveiksle horizontalioje ir vertikalioje ašyse esančios reikšmès.

Šiose funkcijoje koeficientai parinkti su $5 \%$ paklaida.

Priekinès ir galinès pakabų ịveržimas apskaičiuojamas pagal 2.8 formulę:

$$
\left\{\begin{array}{l}
F_{0 k f}=\frac{l_{f}}{\left(l_{f}+l_{r}\right)} \cdot M \cdot g, \\
F_{0 k r}=\frac{l_{r}}{\left(l_{f}+l_{r}\right)} \cdot M \cdot g,
\end{array}\right.
$$

čia $g$ - laisvo kritimo pagreitis $g=9,81 \mathrm{~m} / \mathrm{s}^{2}$.

Priekinio ir galinio amortizatoriaus charakteristikos vienodos. Pusiau aktyvaus amortizatoriaus slopinimo netiesinès charakteristikos skiriasi nuo tiesinių (2.4 pav. ir 2.5 pav.). 2.4 paveiksle charakteristikos sudarytos autoriaus pagal netiesines funkcijas ir naudojantis programinès įrangos PC Crash 8.1 duomenų baze. Didžiausias skirtumas suspaudimo metu (2.5 pav.), kai amortizatoriaus veikimo greičio reikšmès yra neigiamos. Amortizatorių nustatymas, kai didžiausias slopinimas pasiekia maždaug $1000 \mathrm{~N}$ pasipriešinimo jègą, esant netiesiškai kintančiai charakteristikai, o tiesiškai kintančiai - beveik $2000 \mathrm{~N}$ kai $0,9 \mathrm{~m} / \mathrm{s}$ amortizatoriaus veikimo greitis. Charakteristikose pažymèti indikatoriai $0,01 \mathrm{~A}, 0,41 \mathrm{~A}$ ir t. t. žymi srovès stiprị, kuriam esant gaunama atitinkama pasipriešinimo jèga. Generuojamas srovès stipris valdo vožtuvų, esančių amortizatoriaus viduje, atsidarymo laipsni, o tai tiesiogiai turi įtakos pasipriešinimo jègoms. 0,01 A žymi minimalų vožtuvų atsidarymo laipsni. Tokia amortizatorių padètis atitinka tekste ir grafikuose naudojamą sąvoką „maksimalus slopinimas“. Maksimaliai atidaryti vožtuvai, kai srovès stipris yra 1,64 A, tekste vartojama sąvoka „minimalus slopinimas“. 


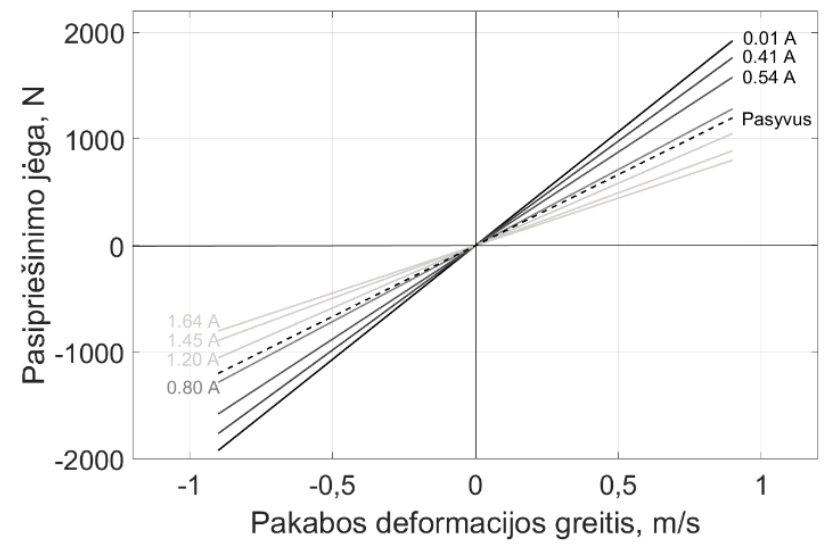

2.4 pav. Amortizatoriaus tiesinès slopinimo charakteristikos esant skirtingam valdymo srovès stipriui

Fig. 2.4. Shock absorber linear damping characteristics with different control current

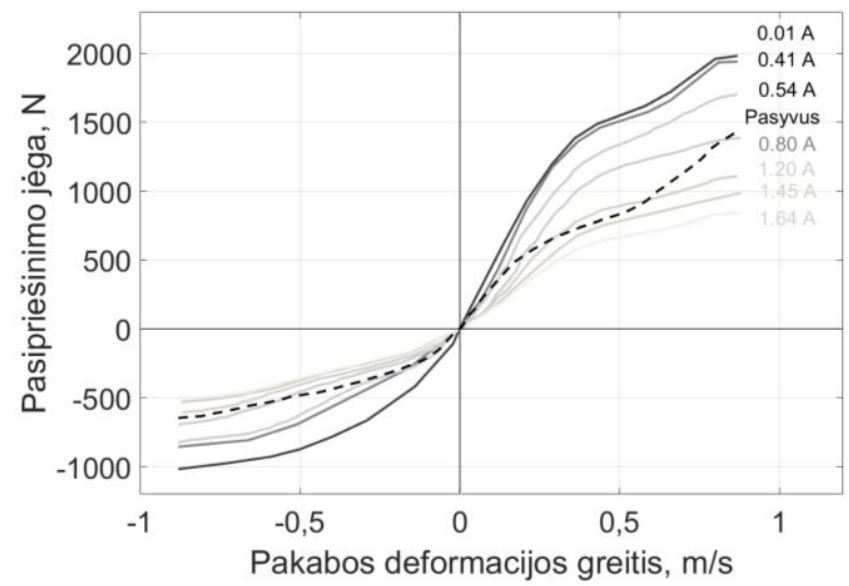

2.5 pav. Amortizatoriaus netiesinès slopinimo charakteristikos esant skirtingam valdymo srovès stipriui (Ślaski 2010)

Fig. 2.5. Shock absorber non-linear damping characteristics with different control current (Ślaski 2010)

Amortizatorių pasipriešinimo jègų kitimą $F_{c M}(\Delta \dot{z})$ aprašo ketvirto laipsnio Furjè funkcija: 


$$
\begin{aligned}
& F_{c M}(\Delta \dot{z})=a_{0}+a_{1} \cdot \cos (d \cdot \Delta \dot{z})+b_{1} \cdot \sin (d \cdot \Delta \dot{z})+a_{2} \cdot \cos (2 \cdot d \cdot \Delta \dot{z})+ \\
& b_{2} \cdot \sin (2 \cdot d \cdot \Delta \dot{z})+a_{3} \cdot \cos (3 \cdot d \cdot \Delta \dot{z})+b_{3} \cdot \sin (3 \cdot d \cdot \Delta \dot{z})+ \\
& a_{4} \cdot \cos (4 \cdot d \cdot \Delta \dot{z})+b_{4} \cdot \sin (4 \cdot d \cdot \Delta \dot{z}),
\end{aligned}
$$

čia $\Delta \dot{z}$ ir $F_{c M}(\Delta \dot{z})-2.5$ paveiksle horizontalioje ir vertikalioje ašyse esančios reikšmès, $a_{0}, a_{1}, b_{1}, a_{2}, b_{2}, a_{3}, b_{3}, a_{4}, b_{4}, d$ - koeficientai su $5 \%$ paklaida. Šie koeficientai pateikti 2.2 lentelëje.

2.2 lentelè. Parametrai, įvertinantys slopinimo jègų kitimą

Table 2.2. Coefficients assessing variation of damping forces

\begin{tabular}{|l|c|c|c|c|c|c|c|c|}
\hline \multirow{2}{*}{ Parametras } & \multicolumn{7}{|c|}{ Pasipriešinimo jègų kitimo koeficientai pagal generuojamos } \\
\cline { 2 - 9 } & $\mathbf{0 , 0 1} \mathbf{A}$ & $\mathbf{0 , 4 1} \mathbf{A}$ & $\mathbf{0 , 5 4} \mathbf{A}$ & $\mathbf{0 , 8 0}$ A & $\mathbf{1 , 2 0}$ A & $\mathbf{1 , 4 5}$ A & $\mathbf{1 , 6 4}$ A & Pasyvus \\
\hline$a_{0}(\mathrm{~N})$ & 386,3 & 375,9 & 231,8 & 235,4 & 165,4 & 79,41 & 79,85 & 268,1 \\
\hline$a_{1}(\mathrm{~N})$ & $-96,02$ & $-172,2$ & 37,52 & -120 & $-97,09$ & $-13,34$ & $-88,09$ & $-38,98$ \\
\hline$b_{1}(\mathrm{~N})$ & 1477 & 1347 & 1247 & 1010 & 816,7 & 729,9 & 623,3 & 955,3 \\
\hline$a_{2}(\mathrm{~N})$ & $-154,4$ & $-101,8$ & -237 & $-100,2$ & $-54,11$ & $-98,29$ & $-16,74$ & $-136,2$ \\
\hline$b_{2}(\mathrm{~N})$ & $-251,7$ & $-295,7$ & -232 & $-223,3$ & $-187,6$ & $-148,4$ & $-141,8$ & -218 \\
\hline$a_{3}(\mathrm{~N})$ & 21,07 & $-35,17$ & 57,81 & $-56,14$ & $-45,3$ & 1,989 & $-40,56$ & 90,28 \\
\hline$b_{3}(\mathrm{~N})$ & 214,6 & 196,6 & 130,4 & 118,6 & 112,7 & 85,99 & 85,09 & 140,3 \\
\hline$a_{4}(\mathrm{~N})$ & $-91,74$ & $-79,43$ & -103 & $-29,06$ & $-21,3$ & $-43,56$ & $-6,069$ & $-68,76$ \\
\hline$b_{4}(\mathrm{~N})$ & $-49,54$ & $-73,88$ & $-28,83$ & $-51,26$ & $-39,62$ & $-24,77$ & $-26,06$ & 23,8 \\
\hline$d(\mathrm{rad} \cdot \mathrm{s} / \mathrm{m})$ & 2,614 & 2,677 & 2,435 & 2,598 & 2,647 & 2,397 & 2,705 & 2,368 \\
\hline
\end{tabular}

2.9 formuleje pateikta funkcija ir 2.2 lenteleje matomi koeficientai naudoti teoriniuose tyrimuose aprašant amortizatorių pasipriešinimo jègų kitimą, priklausantị nuo amortizatoriaus veikimo greičio. 


\subsection{Amortizatorių suveikimo uždelsimas}

Automobiliuose naudojami pusiau aktyvūs amortizatoriai veikia su uždelsimu, kuris skirstomas i dvi pagrindines grupes:

- siunčiamo srovès stiprio uždelsimas nuo valdymo modulio iki amortizatorių vožtuvo ir jo suveikimo;

- amortizatoriaus slopinimo reikšmės pakeitimo uždelsimas.

Elektrinis uždelsimas trunka apie $18 \mathrm{~ms}$, o hidromechaninis - vidutiniškai 55 ms (2.6 pav.). Pasipriešinimo jègos pakeitimas skiriasi, jei amortizatorius veikia suspaudimo ir pailgejjimo režimais. Suspaudimo metu atsiranda didesnè spyruoklès standumo jèga, todèl skaičiuojama, kad amortizatoriaus pasipriešinimo jègos pokyčiai trunka apie $67 \mathrm{~ms}$. Amortizatorius, veikdamas pailgèjimo režimu, greičiau pakeičia pasipriešinimo jègą - tai trunka apie $43 \mathrm{~ms}$ (Więckowski et al. 2018).
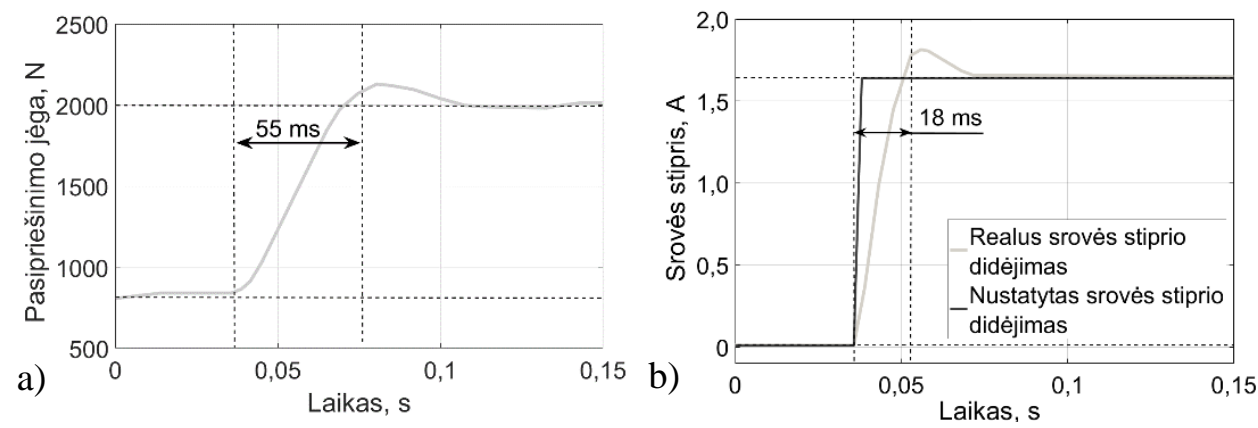

2.6 pav. Amortizatoriaus veikimo priklausomybès: a) pasipriešinimo jègos nuo laiko;

b) srovès stiprio nuo laiko (Więckowski et al. 2018)

Fig. 2.6. Shock absorber characteristics: a) damping force dependence of time;

b) current dependence of time (Więckowski et al. 2018)

Pradèjus kisti srovès stipriui, kinta ir pasipriešinimo jèga. Nebūtina sulaukti, kol srovès stipris ịgis norimą reikšmę, tad bendras amortizatoriaus uždelsimas nuo mažiausios reikšmès iki didžiausios pasikeičia su apytiksliai 0,055 s uždelsimu (Savaresi, Spelta 2009, Więckowski et al. 2018).

Amortizatorių veikimo uždelsimas turi įtakos „Skyhook“ ir kitiems valdymo principams, kurie keičia pasipriešinimo jègą realiu laiku. Norimos reikšmès yra pasiekiamos ne tada, kai jų reikia, bet po tam tikro laiko momento. Siūlomi pusiau aktyvios pakabos valdymo algoritmai, aprašyti 2.10 poskyryje, neturi minètų trūkumų dẻl pakabos veikimo uždelsimo, nes norimų reikšmių signalas išsiunčiamas anksčiau nei ratas užvažiuoja ant kliūties. Daroma prielaida, kad amortizatoriaus pasipriešinimo jẻgos yra keičiamos per maksimalų laiką - 0,073 s. 


\subsection{Pavieniai ir ištisiniai kelio paviršiaus nelygumai}

Kelio profiliui imituoti pasirinkti du skirtingo aukščio, pusès sinusoidès formos kelio nelygumai. Pirmasis - 0,05 m aukščio pasirinktas, nes tokios pačios formos ir dydžio greičio mažinimo kalnelis naudotas eksperimentiniuose tyrimuose (2.7 pav.). Antrasis - 0,1 m aukščio kalnelis pasirinktas, nes atliekami teoriniai bandymai norint patikrinti automobilio dinaminius parametrus veikiant standumo elementams visu diapazonu. Nelygumo formą aprašo formulè:

$$
z_{r}(t)=\frac{H}{2} \cdot\left(1-\cos \left(2 \pi \cdot \frac{v \cdot t}{L}\right)\right),
$$

čia $H$ - nelygumo aukštis (naudotas $0,05 \mathrm{~m}$ ir $0,1 \mathrm{~m}$ ); $L$ - nelygumo ilgis (naudotas $0,35 \mathrm{~m}) ; v$-transporto priemonès greitis; $t$ - laikas.

Kelio nelygumo ilgis priklauso nuo transporto priemonès judejjimo greičio. Jei transporto priemonè juda greičiau, pervažiavimo per kliūti trukmė bus mažesnè.

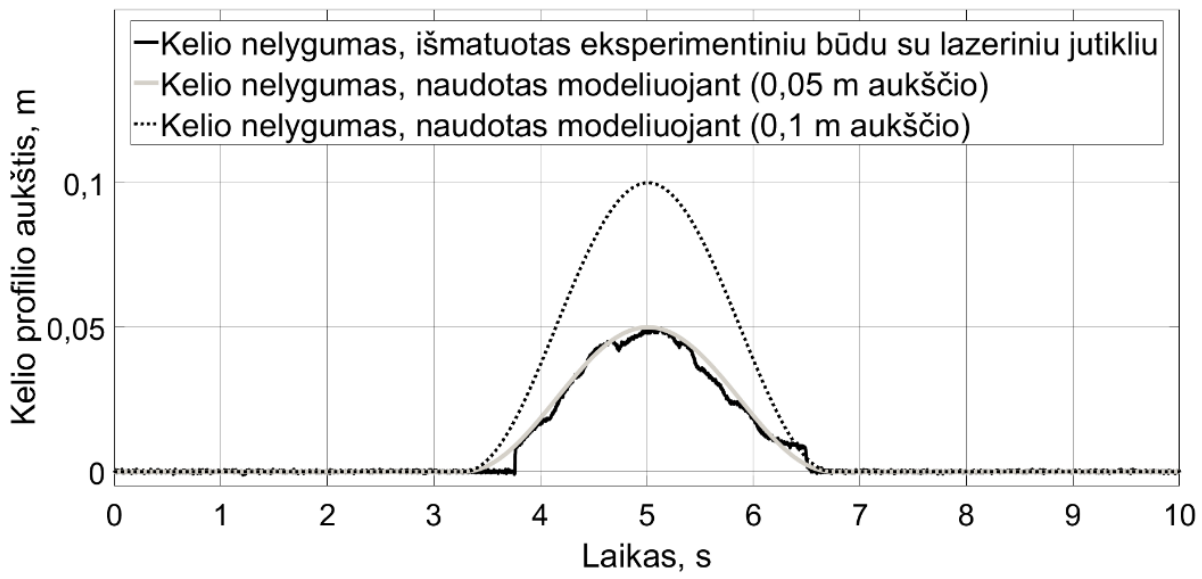

2.7 pav. Kelio nelygumo forma, naudota modeliuojant

Fig. 2.7. The shape of obstacle used in simulation

Naudojant tyrimuose $0,05 \mathrm{~m}$ ir $0,1 \mathrm{~m}$ aukščio kelio nelygumus, tikslinga žinoti, kokio dažnio virpesiai pavojingi transporto priemonei važiuojant per minètus kelio nelygumus. Kelio nelygumų dažnis apskaičiuojamas pagal šią formulę (Bogdevičius 2012): 


$$
\Omega=\frac{2 \pi}{L_{n}} \cdot v,
$$

čia $\Omega$ - kelio nelygumų dažnis; $L_{n}$ - kelio bangos periodo pusė, apskaičiuojama pagal 2.12 formulę.

$$
L_{n}=\frac{L}{2},
$$

čia $L$ - kelio bangos vienas periodas.

Tyrimai atlikti transporto priemonei važiuojant $10 \mathrm{~km} / \mathrm{h}, 30 \mathrm{~km} / \mathrm{h}, 50 \mathrm{~km} / \mathrm{h}$ ir $80 \mathrm{~km} / \mathrm{h}$ greičiais, tad kelio profilio dažnis yra toks: $10 \mathrm{~km} / \mathrm{h}$ greičiu $-16 \mathrm{~Hz}$, $30 \mathrm{~km} / \mathrm{h}-48 \mathrm{~Hz}, 50 \mathrm{~km} / \mathrm{h}-79 \mathrm{~Hz}, 80 \mathrm{~km} / \mathrm{h}-127 \mathrm{~Hz}$.

Siekiant validuoti matematini modelị, teoriniuose bandymuose kelio paviršius turi būti kaip eksperimentinių bandymų. Todèl pusès sinusoidès formos kelio nelygumas aprobuotas vertikaliu kelio paviršiaus šiurkštumu, kurị aprašo ISO 8608 standartas. Šiame standarte pateikiama išilginio kelio profilio paviršiaus klasifikacija (Krauze, Kasprzyk 2016a; Dąbrowski, Ślaski 2016; Barbosa 2011). Pagal kelio paviršių danga gali būti suklasifikuota ị 8 klases $(A-H)$. Standarte naudojamas dydis, vadinamas nelygumo galios spektriniu tankiu (angl. Power spectral density). Šis dydis apskaičiuojamas pagal 2.13 formulę (Barbosa 2011; Prashant et al. 2018):

$$
S_{d}(n)=S_{d}\left(n_{o}\right) \cdot\left(\frac{n}{n_{o}}\right)^{w},
$$

čia $n$ - ciklinis skaičius ( $n_{o}=0,1$ cikl./m ); $w$ - kelio paviršiaus banguotumas $(1,8 \div 3,3)$, rodiklis $S_{d}\left(n_{o}\right)$ apskaičiuojamas pagal formulę:

$$
S_{d}\left(n_{o}\right)=4^{c_{n}+1,0},
$$

čia $c_{n}$-klasès numeris nuo 1 iki 8 (2.3 lentelè). A klasès keliu laikomas kokybiškas asfaltas su $16 \cdot 10^{-8} \mathrm{~m}^{3}$ geometrinio vidurkio dydžio nelygumais $1 \mathrm{~m}$ kelio paviršiaus. Pagal tarptautinị kelio indeksą $A$ klasès kelią atitinka $I R I=1,92$.

Taip pat kelio klases galima išreikšti kvadratinio vidurkio reikšme (angl. Root Mean Square) (Barbosa 2011):

$$
S_{R M S}(n)=\sqrt{S_{d}(n)} .
$$


2.3 lentelè. Kelio klasifikacija pagal ISO 8608 standartą

Table 2.3. Road classification accroding to ISO 8608 standard

\begin{tabular}{|c|c|c|c|}
\hline Klasės numeris & Kelio klasé & $S_{d(n=1)}\left(\times 10^{-6} \mathrm{~m}\right)$ & $S_{R M S(n=1)}\left(\times 10^{-3} \mathrm{~m}\right)$ \\
\hline \hline 1 & $A$ & 0,16 & 0,4 \\
\hline 2 & $B$ & 0,64 & 0,8 \\
\hline 3 & $C$ & 2,56 & 1,6 \\
\hline 4 & $D$ & 10,24 & 3,2 \\
\hline 5 & $E$ & 40,96 & 6,4 \\
\hline 6 & $F$ & 163,84 & 12,8 \\
\hline 7 & $G$ & 655,36 & 25,6 \\
\hline 8 & $H$ & 2621,44 & 51,2 \\
\hline
\end{tabular}

Matematiniame modelyje naudojamas papildomas kelio nelygumas, kuris aprašomas pagal formulę (Žuraulis, Sokolovskij 2018):

$$
\dot{z}_{o}(t)=-2 \pi \cdot v(t) \cdot n_{o} \cdot z_{0}(t)+w(t) \cdot \sqrt{S_{d}\left(n_{o}\right) \cdot a(t)},
$$

čia $v(t)$-judèjimo greitis, $a(t)$ - judèjimo pagreitis.

Matematiniam modeliui validuoti atlikti eksperimentiniai tyrimai ant $B$ klasès kelio dangos. Pusès sinusoidès formos kelio nelygumas su ISO 8608 B klasès kelio danga pavaizduotas 2.8 paveiksle.

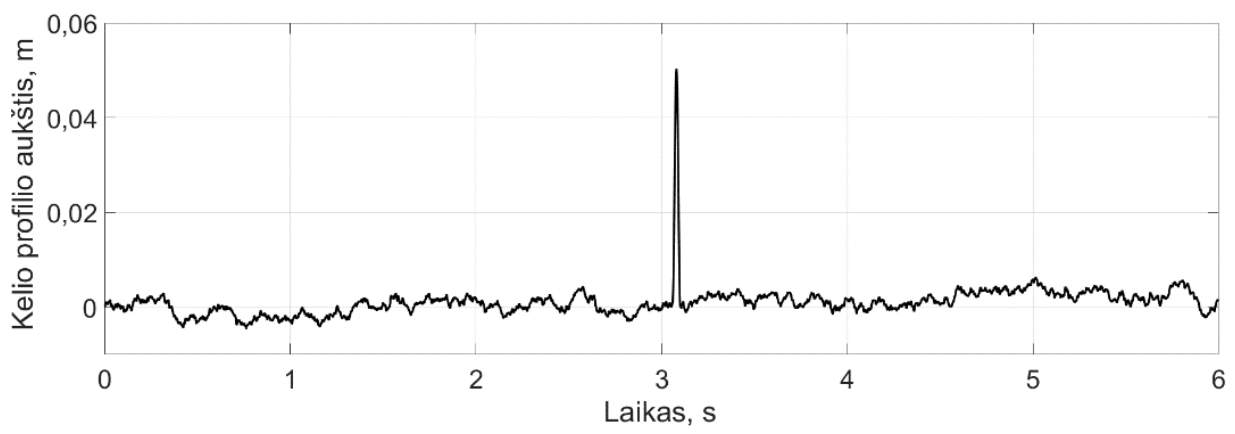

2.8 pav. Kelio nelygumo profilis $(0,05 \mathrm{~m})$ su ISO $8608 B$ klasès kelio danga, kai greitis $30 \mathrm{~km} / \mathrm{h}$

Fig. 2.8. Road irregularity profile $(0,05 \mathrm{~m})$ with ISO $8608 \mathrm{~B}$-class road surface at $30 \mathrm{~km} / \mathrm{h}$ velocity 
Nelygumo spektrinio tankio reikšmės yra atsitiktinès, todėl toks signalas tinkamas imituoti nepasikartojantị kelio paviršių. Eksperimentiniai bandymai atlikti ant ne naujos asfalto kelio dangos, todèl turi nedidelių, maždaug $5 \mathrm{~mm}$ aukščio, nelygumų. Matematinis pusės automobilio modelis, važiuodamas (2.8 pav.) paviršiumi su $B$ klasės kelio danga, tiksliai atkartoja kelio paviršių, ant kurio buvo atliekami eksperimentiniai tyrimai.

\subsection{Matematinio pusès automobilio su sumontuotu lazeriniu atstumo jutikliu modelio validavimas}

Sukūrus matematinị modelị Matlab/Simulink aplinkoje (2.2 pav.) ir norint jị naudoti teoriniuose tyrimuose, reikia modelị validuoti eksperimentiniais tyrimais. Eksperimentiniai tyrimai atlikti „Opel Astra“ automobiliu (informacija apie eksperimentinius tyrimus pateikta 3 skyriuje). Kompiuterinio modeliavimo rezultatams palyginti pasirinkti pakabos eigos greičio, sukimosi apie skersinę aši kampinio greičio ir neamortizuotos masės pagreičio parametrai. Norint tiksliau ịvertinti modelio tikslumą atitinkančius realius bandymus, pasirinktas skirtingas amortizatorių slopinimas - maksimaliai didelis ir maksimaliai mažas.

2.9 paveiksle pateiktos pakabos eigos greičio su skirtingais slopinimais rezultatai. Iš grafikų matyti, kad kreivès yra panašios. Pirmu numeriu pažymètose dalyse matomas skirtumas tarp simuliavimo ir eksperimentiniu bandymo rezultatų. Šis skirtumas yra dèl modelyje aprašyto rato. Modelyje ratas su kelio paviršiumi kontaktuoja viename taške, o eksperimentiniuose bandymuose ratas turèjo didelị kontakto plotą, todèl, užvažiuojant ant kliūties, pakabos eigos greitis neturi staigaus padidejjimo. 2.9 paveiksle antru numeriu pažymètose dalyse tiek eksperimentiniu būdu, tiek teoriniais tyrimais gautos kreivès yra labai panašios. Esant minimaliam slopinimui, liekamujų paklaidų kvadratų suma $S S E=91$, vidutinè kvadratinè paklaida $R M S E=0,1748$, o esant maksimaliam slopinimui $S S E=152, R M S E=0,2258$. Tai įrodo, kad pusès automobilio modelis pakankamai tiksliai atkartoja realaus automobilio judejjimą keliu.

2.10 paveiksle pavaizduotas automobilio sukimosi apie skersinę aši kampinis greitis. Analizuojant sukimosi apie skersinę ašį greičio kreives, galima pastebèti, kad, pasirinkus skirtingus pakabos reguliavimus, eksperimentiniais ir teoriniais tyrimais gauti rezultatai koreliuoja: kai pakaba sureguliuota su minimaliu slopinimu, sukimas apie skersinę ašį maksimaliai yra nuo $5 \%$ s iki $-5 \%$, o maksimaliu slopinimu - nuo $5 \%$ s iki $-3 \%$ s. 


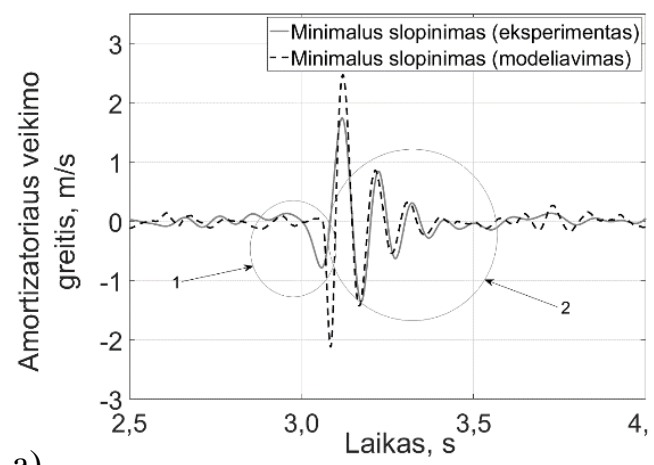

a)

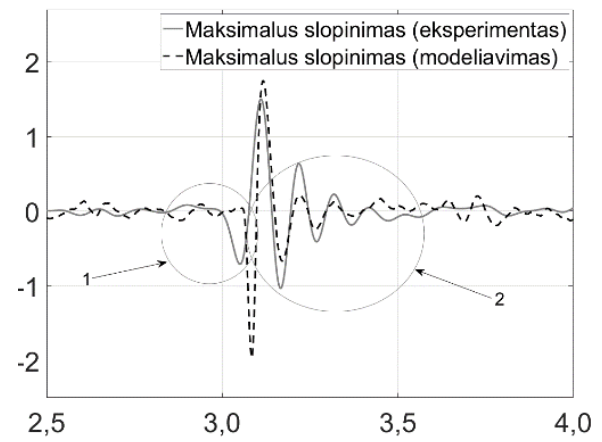

b)

Laikas, $\mathrm{s}$

2.9 pav. Pakabos eigos greitis, kai automobilis juda $30 \mathrm{~km} / \mathrm{h}$ greičiu per kelio nelygumo profili su ISO 8608 B klasès kelio danga: a) esant minimaliam slopinimui;

b) esant maksimaliam slopinimui

Fig. 2.9. Suspension deflection rate when vehicle moves at $30 \mathrm{~km} / \mathrm{h}$ velocity through road irregularity profile with ISO $B$-class road surface: a) with low damping;

b) with high damping
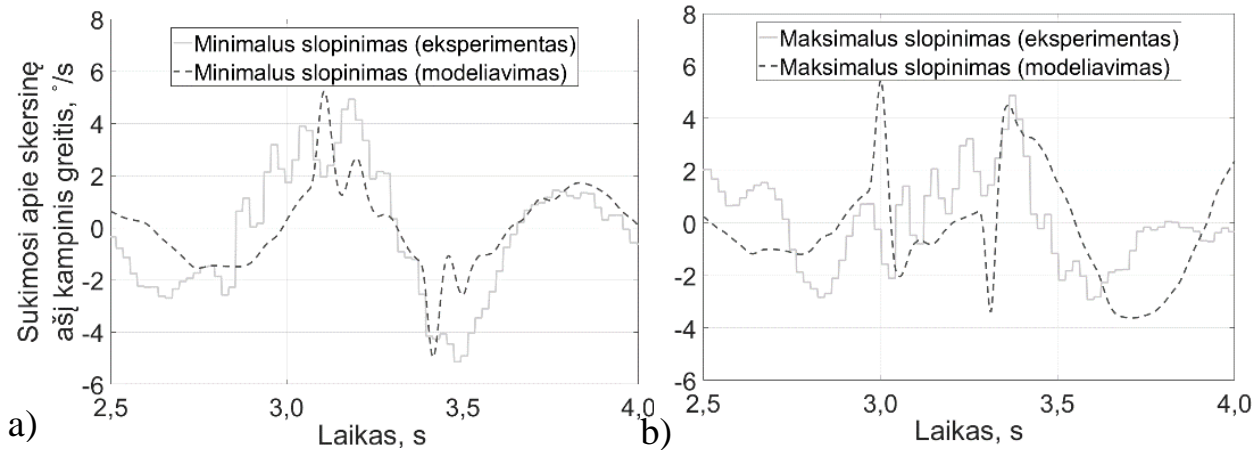

2.10 pav. Sukimosi apie skersinę ašį kampinis greitis, pasirinkus skirtingus amortizatoriu slopinimus: a) esant mažam slopinimui; b) esant dideliam slopinimui Fig. 2.10. Pitch rate with different shock absorber damping: a) with low damping; b) with high damping

Analizuojant neamortizuotos masès pagreitį, pasirinktas dažninių spektro vaizdavimas (2.11 pav.). Iš grafikų matyti, kad amplitudžių rezonansinis dažnis akivaizdus esant $10 \mathrm{~Hz}$. Rezultatų teisingumą patvirtina ISO 2631 standartas (Ślaski, 2011; Levulytè et al., 2014), kuriame nurodytos pikų reikšmès sutampa. Matematinio modeliavimo ir eksperimentinių tyrimų amplitudès sutampa (2.11 pav. 1 nr.). Skirtumas pastebimas ties 17-35 Hz dažniu (2.11 pav. 2 nr.). 
Amplitudžių skirtumą galima būtų paaiškinti anksčiau minètomis pastabomis apie vieno taško rato aprašymą pusès automobilio matematiniame modelyje.
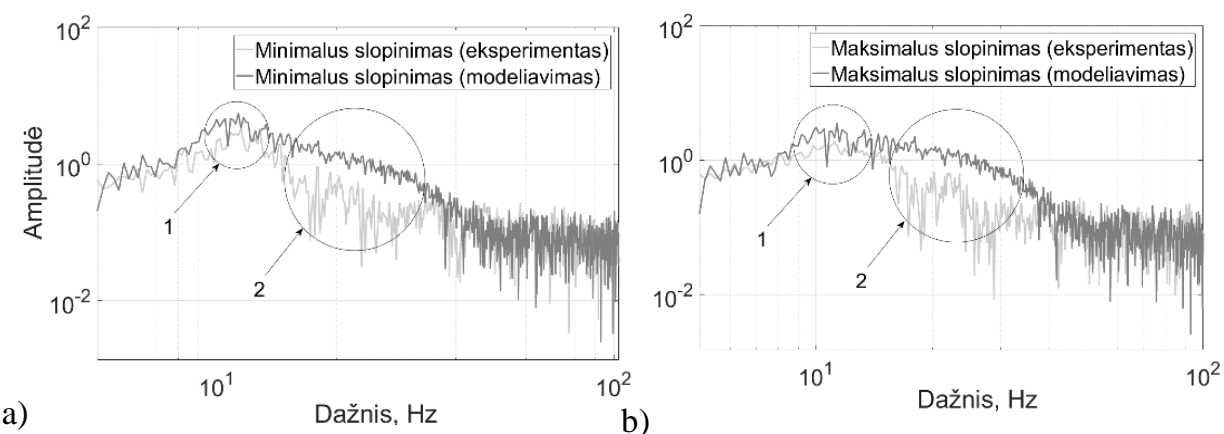

2.11 pav. Neamortizuotos masės pagreičiu dažnių spektras: a) esant mažam slopinimui;

b) esant dideliam slopinimui

Fig. 2.11. Unsprung mass accelaration frequency spectrum: a) with low damping;

b) with high damping

Pateikti rezultatai įrodo, kad matematinis modeliavimas tiksliai atkuria realius bandymus ir pateiktas pusès automobilio matematinis modelis gali būti naudojamas detalesniems tyrimams. Modelis gali būti naudojamas ne tik atliekant bandymus su pasyviomis, bet ir su pusiau aktyviomis pakabomis.

\subsection{Automobilio, važiuojančio per kelio nelygumus, su skirtingomis amortizatoriaus slopinimo savybèmis analizè}

Ir teoriniuose, ir eksperimentiniuose tyrimuose naudojant amortizatorius su skirtingomis slopinimo savybemis, gaunamas skirtingas amortizuotų ir neamortizuotų masių vertikalus judejjimas. Siekiant nustatyti reikiamas slopinimo charakteristikas konkrečiu momentu, teorinès analizès metu atliktas matematinis modeliavimas. Modelyje pasirinktos ribinès tiriamų amortizatorių reikšmès, kai valdymo signalo srovès stipris $0,01 \mathrm{~A}$ (maksimalus slopinimas) ir 1,64 A (minimalus slopinimas). Teorinès analizès metu naudota:

- pusiau aktyvi pakaba su minimaliomis ir maksimaliomis slopinimo reikšmèmis;

- pusės automobilio dinaminis modelis, aprašytas 2.1 poskyryje;

- slopinimo ir standumo charakteristikos, aprašytos netiesinemis funkcijomis; 
- automobilis judejjo $10,30,50 \mathrm{~km} / \mathrm{h}$ greičiais abiem ratais per pusès sinusoidès formos $0,05 \mathrm{~m}$ ir $0,1 \mathrm{~m}$ aukščio kelio nelygumus;

- automobilio parametrai pasirinkti pagal realų automobili „Opel Astra“ (duomenys pateikti 2.1 poskyryje, 2.1 lentelèje).

Sinusoidès formos kelio nelygumai pasirinkti dviejų aukščių: $0,05 \mathrm{~m}$ - tokio aukščio nelygumas naudotas eksperimentiniuose tyrimuose, $0,1 \mathrm{~m}$ aukščio - norint analizuoti automobilio dinamiką, kai standumo elementai veikia charakteristikas pasirinkus ribines reikšmes (2.2 poskyris, 2.5 pav.).

Iš 2.12 paveikslo matyti, kad, rato, užvažiuojančio ant $0,05 \mathrm{~m}$ aukščio nelygumo, amortizuotos masès vertikalus pagreitis yra iki $31 \%$ didesnis, kai slopinimas maksimalus. Automobilio, nuvažiuojančio nuo nelygumo, vertikalaus pagreičio maksimali reikšmė yra didesnè, kai amortizatorių slopinimas taip pat maksimalus (34\% priekinio rato, $39 \%$ galinio rato). Galinis ratas, nuvažiuodamas nuo kliūties, kai slopinimas maksimalus, veikia didesniu pagreičiu nei priekinis, nes neamortizuotos masės svoris yra mažesnis.

Pagal ISO 2631 standartą vertikalaus pagreičio pojūtis žmogui suskirstytas ị grupes (2.4 lentelè). Kai vertikalus pagreitis didesnis nei $2 \mathrm{~m} / \mathrm{s}^{2}$, keleivis jaučia didelị diskomfortą, o komfortiška aplinka yra tada, kai vertikalus pagreitis neviršija $0,315 \mathrm{~m} / \mathrm{s}^{2}$. Todèl vairuotojui ir keleiviams komfortiškas automobilio judejjimas per nelygumus, kai pakaba sureguliuota minimaliu slopinimu.

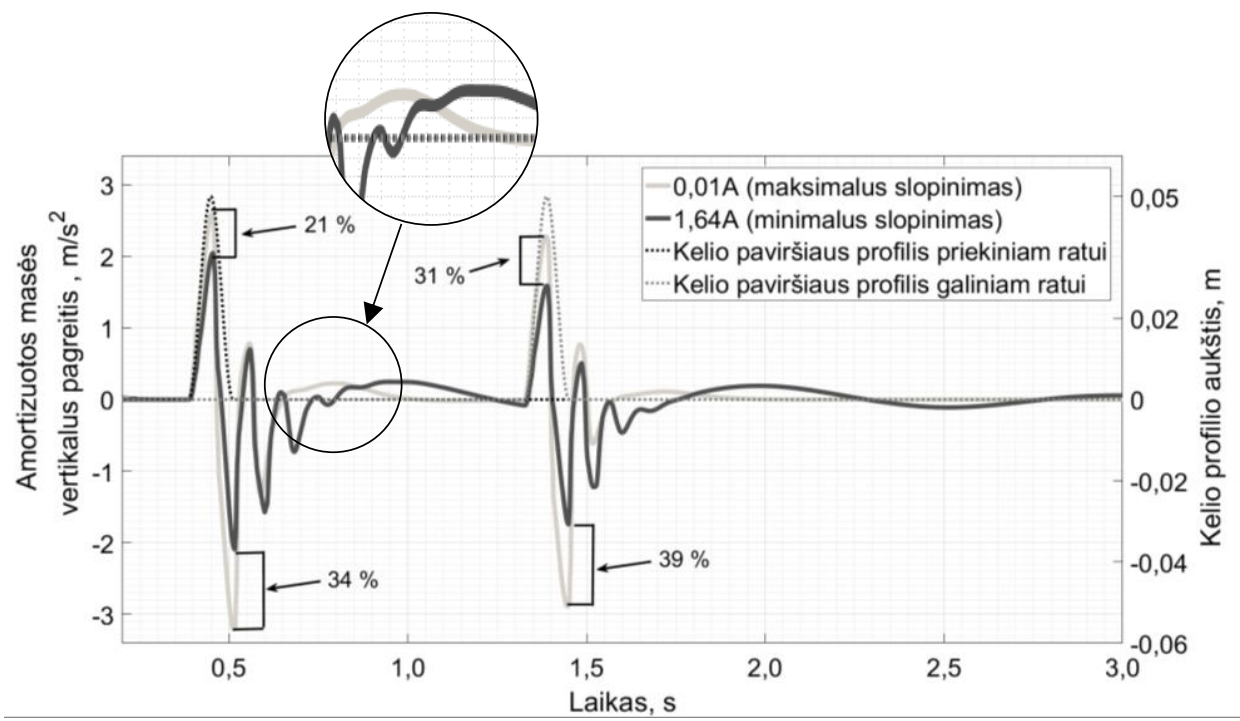

2.12 pav. Amortizuotos masès vertikalus pagreitis, kai slopinimo reikšmės skirtingos $(10 \mathrm{~km} / \mathrm{h}$ greitis $)$

Fig. 2.12. Sprung mass vertical acceleration with different shock absorber damping (speed $10 \mathrm{~km} / \mathrm{h}$ ) 
2.4 lentelė. Vertikalaus pagreičio pojūtis žmogui pagal ISO 2631 standartą

Table 2.4. Vertical acceleration feeling for man accroding to ISO 2631 standard

\begin{tabular}{|c|c|}
\hline Vertikalus pagreitis & Komfortiškumo lygis \\
mažiau kaip $0,315 \mathrm{~m} / \mathrm{s}^{2}-$ & \\
nuo $0,315 \mathrm{~m} / \mathrm{s}^{2}$ iki $0,63 \mathrm{~m} / \mathrm{s}^{2}$ & \\
nuo $0,5 \mathrm{~m} / \mathrm{s}^{2}$ iki $1 \mathrm{~m} / \mathrm{s}^{2}$ & nekomfortiška \\
nuo $0,8 \mathrm{~m} / \mathrm{s}^{2}$ iki $1,6 \mathrm{~m} / \mathrm{s}^{2}$ & \\
nuo $1,25 \mathrm{~m} / \mathrm{s}^{2}$ iki $2,5 \mathrm{~m} / \mathrm{s}^{2}$ & \\
daugiau $\mathrm{kaip} 2 \mathrm{~m} / \mathrm{s}^{2}$ & -
\end{tabular}

2.13 paveiksle pateiktos amortizuotos masès vertikalaus pagreičio priklausomybės nuo laiko esant skirtingam judejjimo greičiui ir nelygumų aukščiui. Skirtumas tarp amortizatorių nustatymų nuvažiuojant nuo kliūties didesnis esant mažam greičiui. Didèjant greičiui amplitudžių skirtumas išlieka didelis ratui užvažiuojant ant kliūties. Automobiliui važiuojant su maksimaliu ar minimaliu slopinimu sureguliuotais amortizatoriais maksimalios pagreičių reikšmès esant $10 \mathrm{~km} / \mathrm{h}$ ir $30 \mathrm{~km} / \mathrm{h}$ greičiui išlieka panašios ir nepriklauso nuo važiavimo greičio. Pagreičio amplitudžių sumažėjimas pastebimas pasiekus $50 \mathrm{~km} / \mathrm{h}$ greitị. Važiuojant didesniu greičiu ratas ,peršoka“ kelio nelygumus, todèl amortizuotos masės pagreitis yra mažesnis. $50 \mathrm{~km} / \mathrm{h}$ greičiu važiuojant per $0,1 \mathrm{~m}$ kelio nelygumą galinio rato vertikalus pagreitis tampa didesnis už priekinio rato pagreitị. Tam turi įtakos svyruojanti amortizuota masė dèl priekinio rato žadinimo. Svyravimai nespèja susilpnèti pervažiavus priekiniu ratu kelio nelygumą, o tik padidèja pervažiavus galiniu ratu. Visais atvejais užvažiuojant ant nelygumo amortizuotos masès vertikalus pagreitis yra mažesnis, jei amortizatoriai sureguliuoti minimaliu slopinimu. Nuvažiuojant nuo nelygumo, amortizuotos masès pagreičio skirtumas nėra toks akivaizdus, kai amortizatorių slopinimas skirtingas. $50 \mathrm{~km} / \mathrm{h}$ greičiu nuvažiuojant galiniais ratais nuo kliūties per $0,1 \mathrm{~m}$ aukščio nelygumą vertikalus pagreitis yra tokio pat dydžio kaip ir minimaliu ir maksimaliu slopinimu sureguliavus pakabą, tačiau svyravimai greičiau nuslopinami, kai pakaba sureguliuota maksimaliu slopinimu. Išanalizavus 2.12 ir 2.13 paveikslų duomenis, galima daryti išvadą, kad automobiliui užvažiuoti ant kliūties yra palankiau su minimaliu amortizatorių slopinimu, o nuvažiuoti nuo kliūties su maksimaliu slopinimu - amortizuotos masès svyravimai yra greičiau nuslopinami.

2.14 paveiksle pateiktos amortizuotos masės vertikalaus poslinkio priklausomybès nuo laiko svorio centro taške automobiliui važiuojant $10 \mathrm{~km} / \mathrm{h}$ greičiu per 
$0,05 \mathrm{~m}$ aukščio kelio nelygumą. Iš kreivių matyti, kad amortizuota masė, nuvažiuodama priekiniais ratais nuo kliūties, turi panašų vertikalų poslinkị aukštyn (skirtumas $\sim 1 \mathrm{~mm}$ ), palyginti su maksimaliu ir minimaliu slopinimu sureguliuota pakaba.
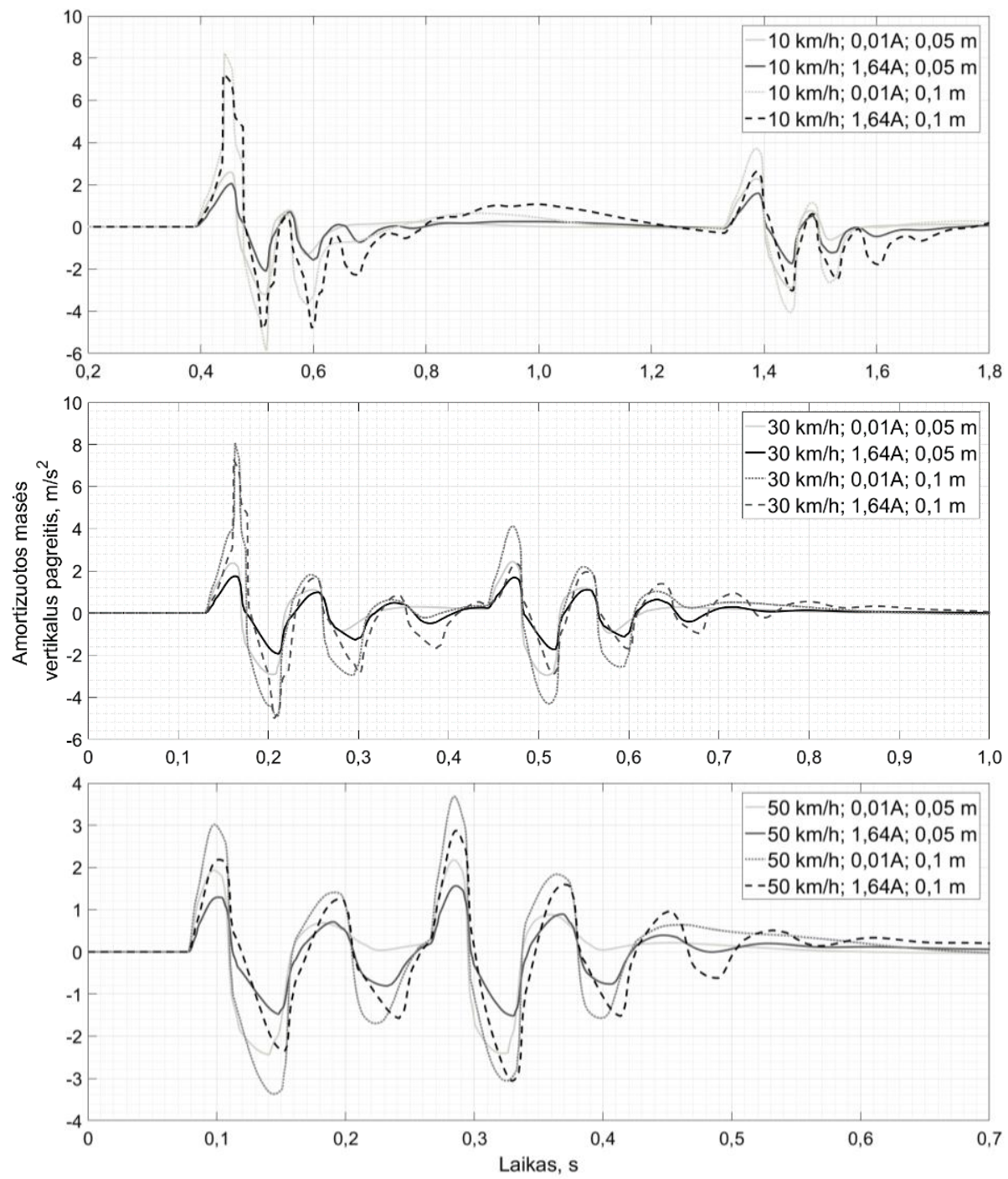

2.13 pav. Minimaliu ir maksimaliu slopinimu veikiančios pakabos amortizuotos masès vertikalus pagreitis esant skirtingam greičiui ir kelio nelygumams

Fig. 2.13. Vertical acceleration of sprung mass of the suspension with minimum and maximum damping at different speeds and road irregularities 
Tačiau skirtumas atsiranda amortizuotai masei svyruojant žemyn (neigiama poslinkio zona) ir nuvažiuojant nuo kliūties su galiniais ratais (2.14 pav. pažymèta 1 numeriu) - vertikalus poslinkis mažesnis esant maksimaliam slopinimui. Svyravimai greičiau nuslopinami, nes amortizatoriai veikia maksimaliomis pasipriešinimo jègomis. Sukimosi apie skersinę aši kampas yra 75 \% mažesnis (2.15 pav.) automobiliui priekiniu ratu pervažiavus nelygumą. Automobiliui abiem ratais pervažiavus nelygumą, virpesiai nuslopinami greičiau esant maksimaliam slopinimui (2.14 pav. pažymèta 2 numeriu).

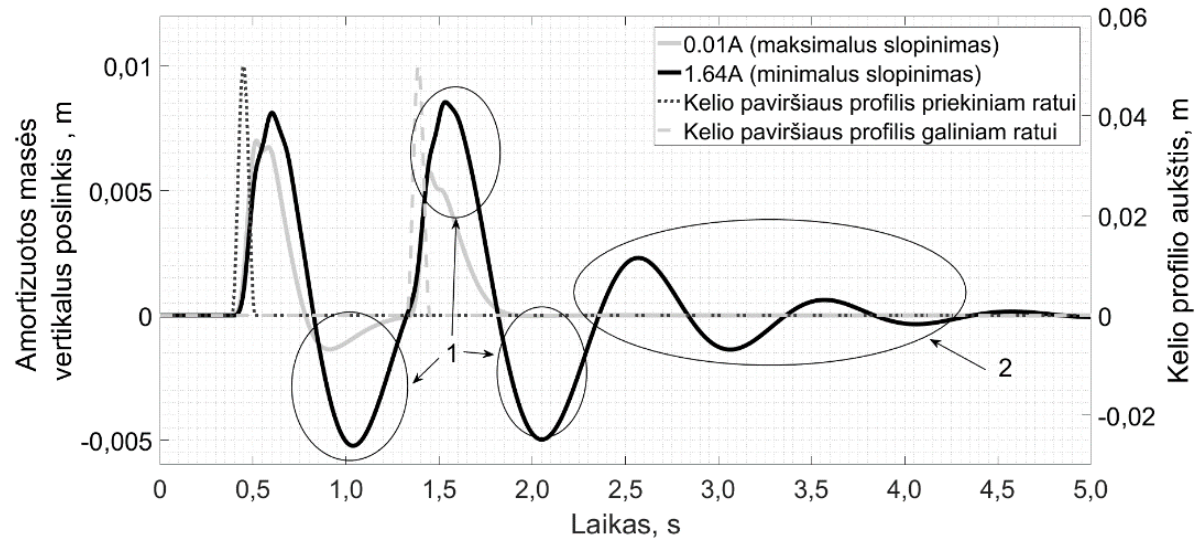

2.14 pav. Amortizuotos masès vertikalus poslinkis esant skirtingoms slopinimo reikšmėms ir $0,05 \mathrm{~m}$ aukščio kelio nelygumui

Fig. 2.14. Sprung mass vertical displacement with different shock absorber damping and $0,05 \mathrm{~m}$ road irregularity height

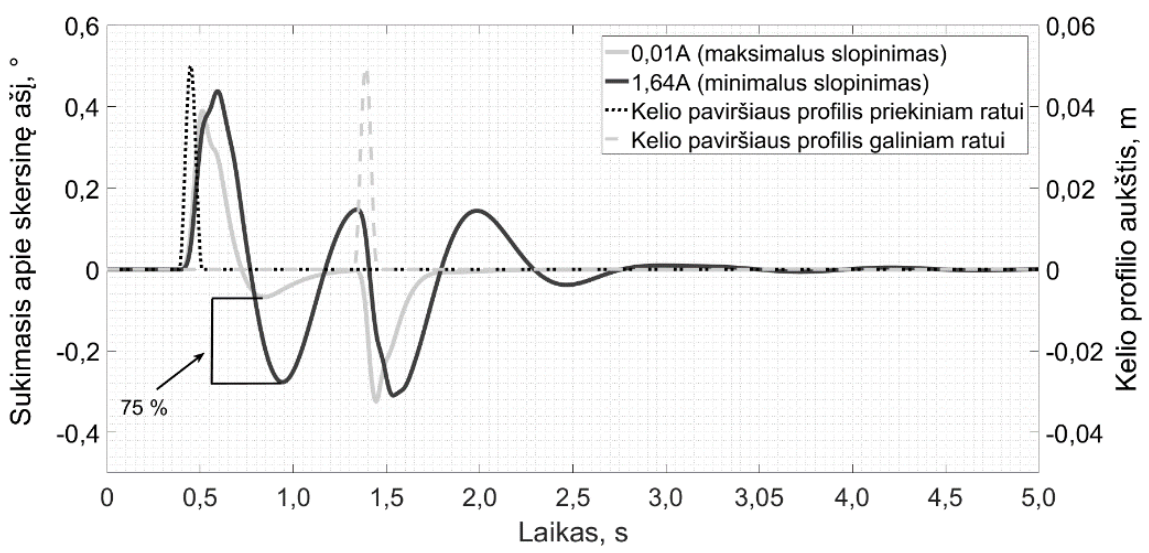

2.15 pav. Sukimasis apie skersinę ašį esant skirtingoms slopinimo reikšmėms (10 km/h greitis ir $0,05 \mathrm{~m}$ aukščio kelio nelygumas)

Fig. 2.15. Pitch with different shock absorber damping (speed $10 \mathrm{~km} / \mathrm{h}$ and $0,05 \mathrm{~m}$ road irregularity height) 
Analizuojant priekinio ir galinio ratų judejjimo vertikalų poslinkị, pervažiuojant per nelygumą (2.16 pav.), pastebimas didesnis poslinkis esant minimaliam slopinimui. Skirtumas didesnis priekiniam ratui nuvažiuojant nuo kliūties nei galiniam. Ittakos turi amortizatorių pasipriešinimo jègos ir neamortizuotos masès svoris. Modelyje jis pasirinktas $45 \mathrm{~kg}$ - priekinis, $35 \mathrm{~kg}$ - galinis.

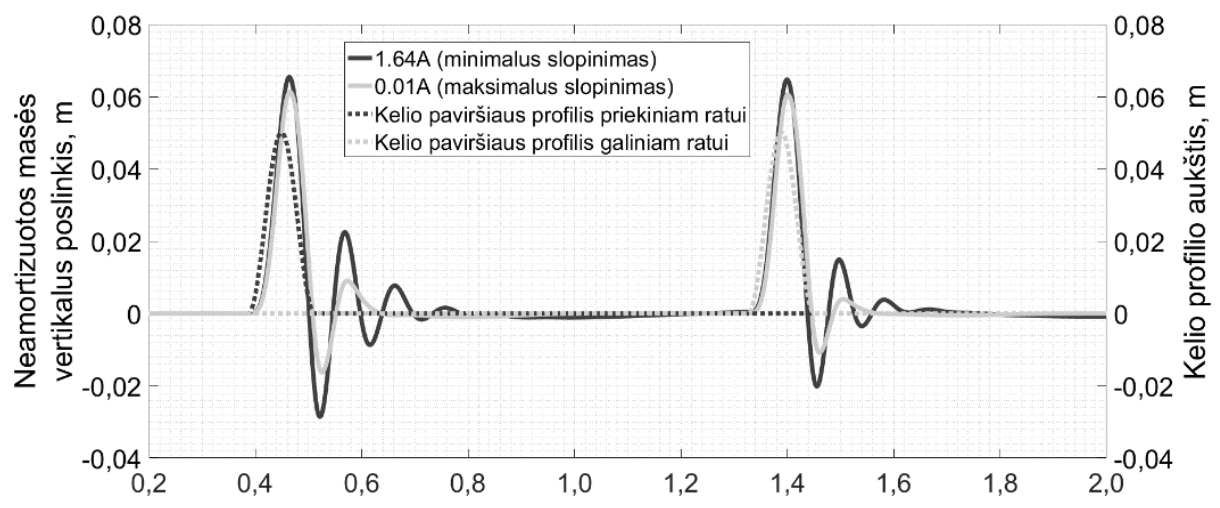

2.16 pav. Neamortizuotų masių vertikalūs poslinkiai esant skirtingoms slopinimo reikšmėms (10 km/h greitis, $0,05 \mathrm{~m}$ aukščio kelio nelygumas)

Fig. 2.16. Unsprung masses vertical displacement with different shock absorber damping (speed $10 \mathrm{~km} / \mathrm{h}, 0,05 \mathrm{~m}$ road irregularity height)

Siekiant tiksliau ịvertinti neamortizuotų masių vertikalius poslinkius, pateiktos priklausomybès 2.17 paveiksle. Matyti, kad, pasiekus didesni greiti $(50 \mathrm{~km} / \mathrm{h})$, neamortizuotų masių poslinkis yra mažesnis, taip pat mažesnis svyravimų skaičius priekiniam ratui nuvažiavus nuo kliūties. Didžiausias poslinkio skirtumas tarp 0,01A ir 1,64A pastebimas, kai automobilis važiuoja $50 \mathrm{~km} / \mathrm{h}$ greičiu per $0,1 \mathrm{~m}$ aukščio nelygumą ir jo galinis ratas užvažiuoja ant nelygumo. Važiuojančiam automobiliui su maksimaliu slopinimu sureguliuotais amortizatoriais poslinkis yra mažesnis nei maksimaliu slopinimu ( 2.17 pav. pažymèta 1 numeriu). Tam itakos turi mažesnis galinio rato svoris, bei trumpas laiko tarpas nuo priekinio rato pervažiavimo per kliūtị, per kurị nespèja neamortizuota masè ịsisiūbuoti.

Kitas analizuojamas parametras - pakabos eiga, kai automobilis juda $10 \mathrm{~km} / \mathrm{h}$ greičiu per $0,05 \mathrm{~m}$ aukščio kelio nelygumą, pateiktas 2.18 paveiksle, o per $0,1 \mathrm{~m}-$ 2.19 paveiksle. Pakabos eigos amplitude yra mažesnè automobiliui važiuojant su maksimaliu slopinimu sureguliuotais amortizatoriais, tik važiuojant per $0,1 \mathrm{~m}$ aukščio nelygumą galinio rato pakabos eigos amplitudè yra didesnė (2.19 pav. pažymėta 1 numeriu). 


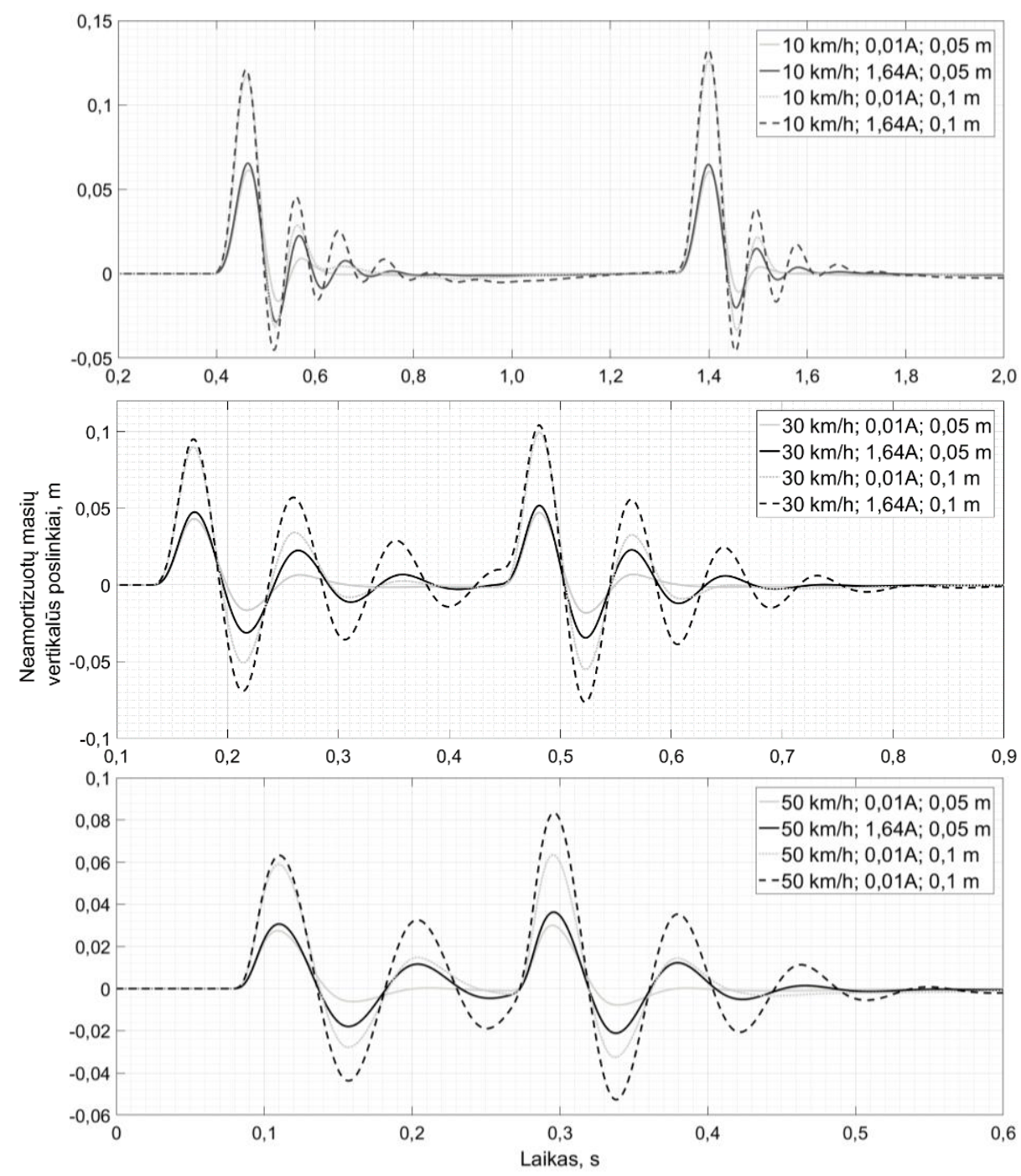

2.17 pav. Minimaliu ir maksimaliu slopinimu veikiančios pakabos neamortizuotų masių vertikalūs poslinkiai esant skirtingiems greičiams ir kelio nelygumams

Fig. 2.17. Vertical displacement of unsprung masses of the suspension with minimum and maximum damping at different speeds and road irregularities

Pervažiavus abiem ratais per $0,5 \mathrm{~m}$ aukščio nelygumą, pakabos eiga po $0,4 \mathrm{~s}$ arteja prie nulinès reikšmės esant maksimaliam slopinimui, o esant minimaliam slopinimui dar maždaug 2,0 s svyruoja. 


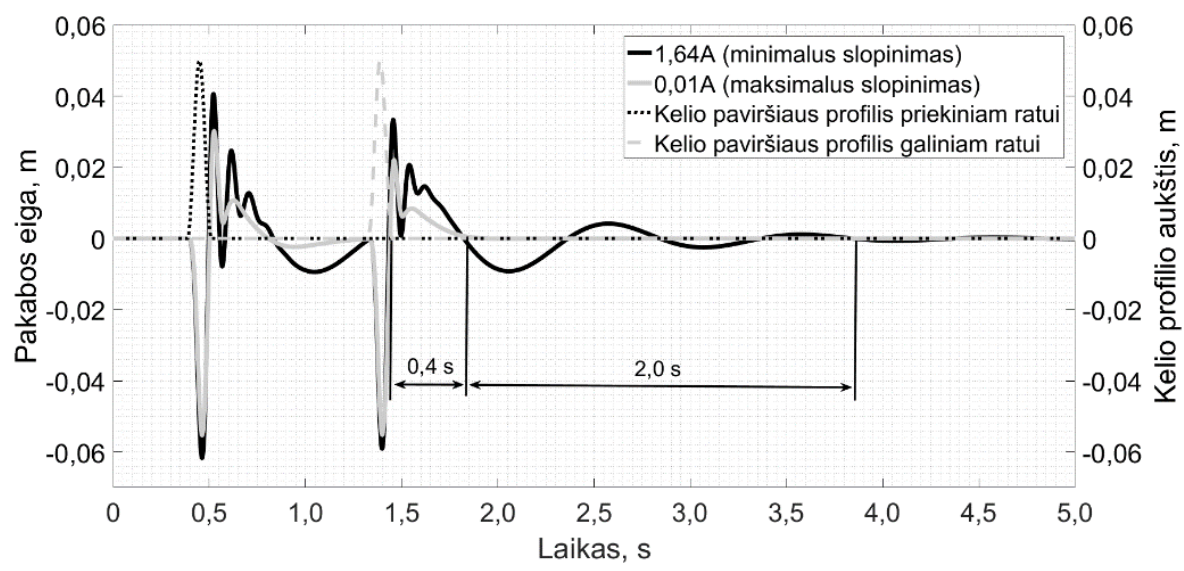

2.18 pav. Pakabos eiga esant skirtingoms slopinimo reikšmèms $(10 \mathrm{~km} / \mathrm{h}$ greitis, $0,05 \mathrm{~m}$ aukščio kelio nelygumas)

Fig. 2.18. Suspension deflection with different shock absorber damping (speed $10 \mathrm{~km} / \mathrm{h}$, $0,05 \mathrm{~m}$ road irregularity height)

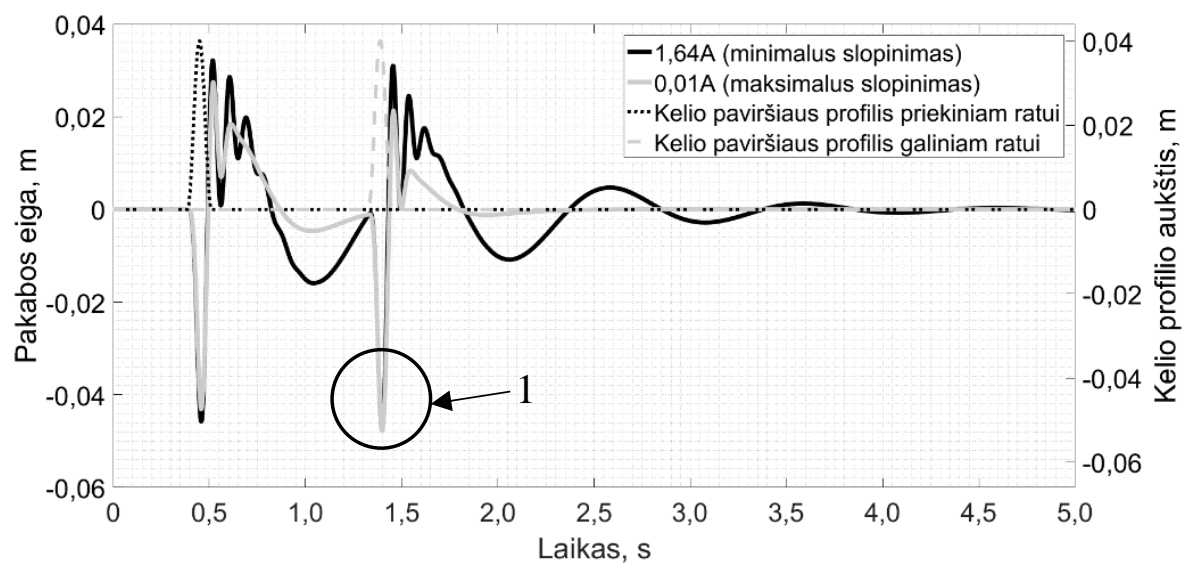

2.19 pav. Pakabos eiga esant skirtingoms slopinimo reikšmėms $(10 \mathrm{~km} / \mathrm{h}$ greitis, $0,1 \mathrm{~m}$ aukščio kelio nelygumas)

Fig. 2.19. Suspension deflection with different shock absorber damping (speed $10 \mathrm{~km} / \mathrm{h}$, $0,1 \mathrm{~m}$ road irregularity height)

Iš atliktos analizès matyti, kad amortizuotos masès poslinkis yra nevienodas skirtingais laiko momentais važiuojant per kelio nelygumus. Automobilio važiavimas su minimaliu slopinimu sureguliuota pakaba suteikia komforto. Amortizuotos masès pagreičiai nèra dideli, palyginti su maksimaliu slopinimu sureguliuotais 
amortizatoriais turinčiu automobiliu, tačiau svyravimai trunka ilgiau. Važiuojant automobiliu su maksimaliu slopinimu turinčia pakaba, mažèja komfortas, bet svyravimai slopinami greičiau.

\subsection{Pasyvios ir pusiau aktyvios pakabos, valdomos „Skyhook“ principu, analizè}

Siekiant palyginti pusiau aktyvios pakabos, valdomos „Skyhook” valdymo principu, ir pasyvios pakabos veikimo dinamiką, atlikta matematinio modelio simuliacija. Modelyje pasirinkti automobilio „Opel Astra“ duomenys (2.1 poskyris). Simuliacija atlikta su netiesine funkcija aprašytomis standumo ir slopinimo elementų charakteristikomis. Simuliavimo metu automobilis judèjo per pusės sinusoidès formos $0,05 \mathrm{~m}$ aukščio nelygumą $30 \mathrm{~km} / \mathrm{h}$ greičiu.

Duomenų analizei pasirinkti šie kintamieji:

- amortizuotos masès vertikalus pagreitis $-\ddot{Z}_{M}$;

- amortizuotos masés vertikalus poslinkis $-z_{M}$;

- sukimosi apie skersinę ašį kampas $-\varphi$.

Pasirinkti šie kintamieji, nes „Skyhook“ valdymo principas orientuotas $\mathfrak{i}$ komforto gerinimą (1.1 lentelè).

Amortizuotos masès vertikalus pagreitis, kai pakaba pasyvi, yra didesnis, palyginti su „Skyhook” valdymo principu. Skirtumas yra didesnis, kai automobilio ratai nuvažiuoja nuo kliūties. Iš 2.20 paveikslo matyti, kad amortizuotos masès svyravimai staigiau sumažeja nuvažiavus nuo kliūties esant pusiau aktyviai pakabai.

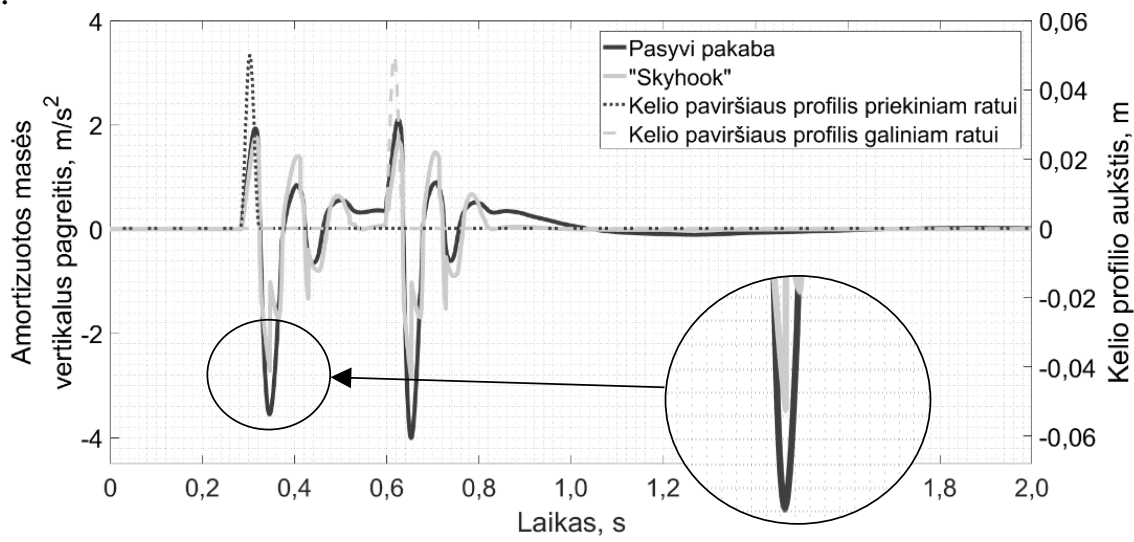

2.20 pav. Amortizuotos masès vertikalus pagreitis esant pasyviai pakabai ir valdomai „Skyhook“ principu, kai greitis $30 \mathrm{~km} / \mathrm{h}$

Fig. 2.20. Sprung mass vertical acceleration with passive suspension and "Skyhook" control at $30 \mathrm{~km} / \mathrm{h}$ velocity 
2.20 paveiksle kreivès vaizduoja staigius ,Skyhook“ valdymo principo pokyčius. Šie pokyčiai atsiranda dèl algoritmo sąlygų, aprašytų 1.12 formulèje.Vertikalus amortizuotos masès poslinkis (2.21 pav.), kai pakaba pasyvi, yra didesnis $(0,009 \mathrm{~m})$ palyginti su „Skyhook” valdymo principu. Automobilio su pusiau aktyvia pakaba svyravimai trunka trumpiau.

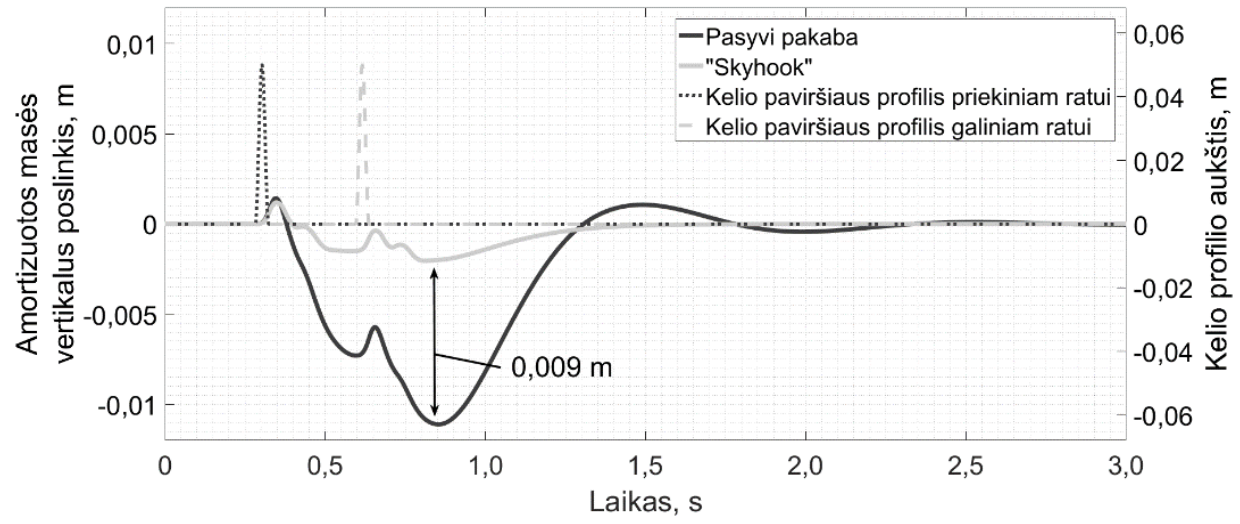

2.21 pav. Amortizuotos masės vertikalus poslinkis esant pasyviai pakabai ir valdomai „Skyhook“ principu, kai greitis $30 \mathrm{~km} / \mathrm{h}$

Fig. 2.21. Sprung mass vertical displacement with passive suspension and "Skyhook" control at $30 \mathrm{~km} / \mathrm{h}$ velocity

Automobiliui važiuojant su pasyvia pakaba matomas didesnis sukimas apie skersinę aši (2.22 pav.). Svyravimai, priekiniu ratu pervažiavus kliūti, yra $0,26^{\circ}$ didesni, o abiem ratais $-0,41^{\circ}$, kai pakaba pasyvi.

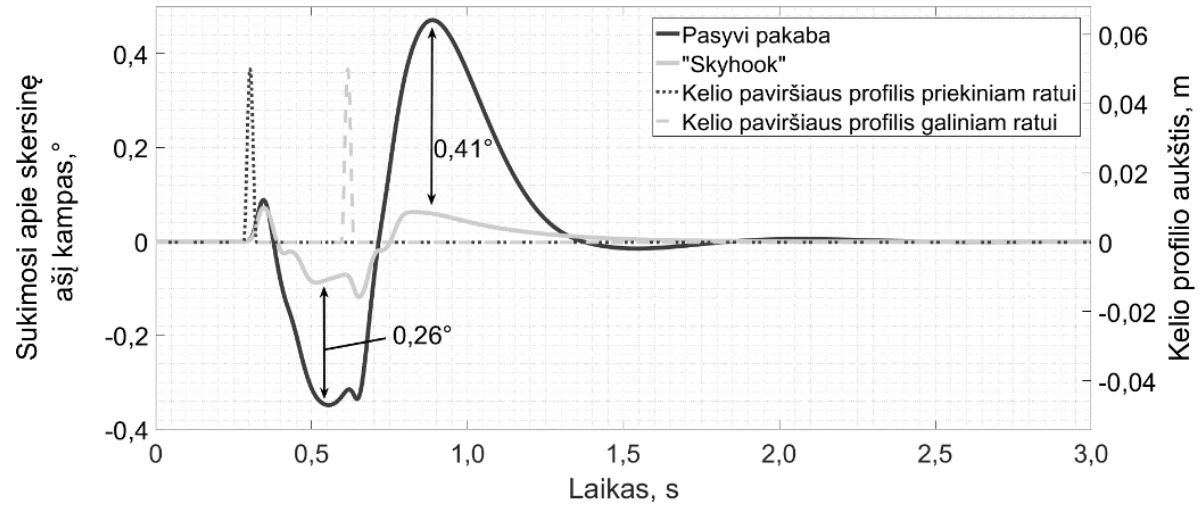

2.22 pav. Sukimasis apie skersinę ašį esant pasyviai pakabai ir valdomai „Skyhook“ principu, kai greitis $30 \mathrm{~km} / \mathrm{h}$

Fig. 2.22. Pitch with passive suspension and "Skyhook" control at $30 \mathrm{~km} / \mathrm{h}$ velocity 
Iš anksčiau pateiktų grafikų matyti pusiau aktyvios pakabos „Skyhook“ valdymo principo privalumai. Pagal ISO 2631 vairuotojui ir keleiviams komfortas didesnis, kai vertikalus amortizuotos masės pagreitis yra mažesnis, automobilio kèbulo svyravimai taip pat greičiau slopinami.

\subsection{Automobilio amortizuotos masès svyravimų kompensavimas}

Norint tiksliai įvertinti atstumą nuo lazerinio jutiklio iki kelio paviršiaus, reikia iš matuojamo lazerinio jutiklio signalo kompensuoti amortizuotos masès svyravimus. Automobilio kèbulo svyravimų atsiranda automobiliui pradejus judèti. Svyravimai skirstomi ị vertikaliuosius - aukštyn, žemyn bei sukimą apie tris ašis, einančias per svorio centrą ( 2.23 pav.):

- sukimas apie skersinę ašį;

- sukimas apie išilginę aši;

- sukimas apie vertikalią ašị.

Tiesiai važiuojantis automobilis svyruoja apie skersinę ašį, todèl šis kampas turi būti kompensuojamas siekiant išsiaiškinti tikslų atstumą nuo kelio paviršiaus iki automobilio kẻbulo. Lazerinio jutiklio signalui apdoroti sukurtas kompensavimo algoritmas (2.24 pav.), kuris eliminuoja iš matuojamo signalo šiuos 3 parametrus:

- amortizuotos masès vertikalų poslinkị svorio centro taške;

- amortizuotos masès vertikalų poslinkị lazerinio jutiklio tvirtinimo vietoje, ji sukelia sukimasis apie skersinę ašį;

- lazerinio jutiklio montavimo padètị (jutiklio montavimo kampą).

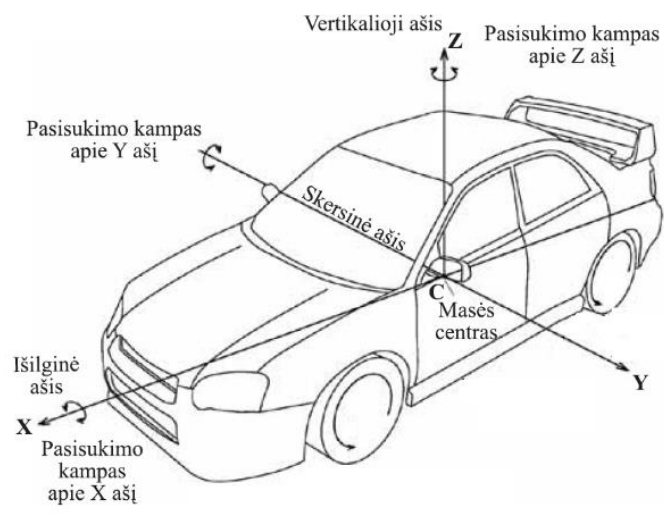

2.23 pav. Automobilio kèbulo svyravimai (Bogdevičius, 2012)

Fig. 2.23. Vehicle body oscillations (Bogdevičius, 2012) 


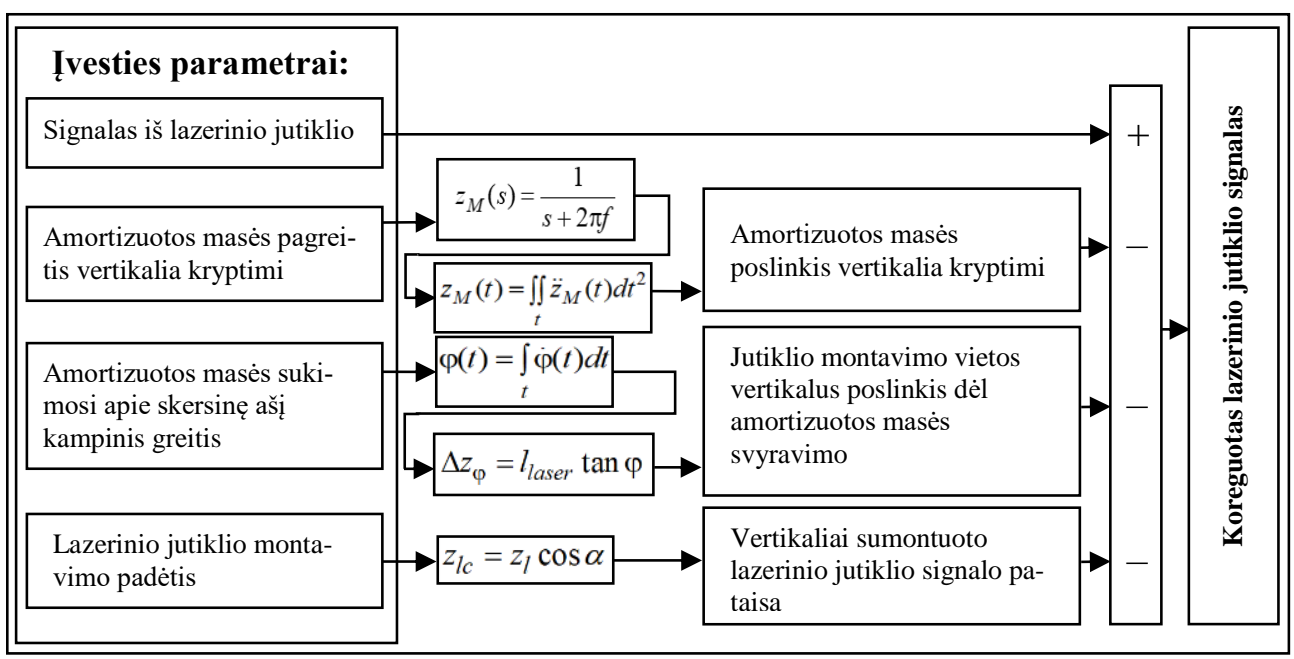

2.24 pav. Lazerinio atstumo jutiklio signalo kompensavimas

Fig. 2.24. Laser height sensor signal compensation

\subsubsection{Amortizuotos masès vertikalaus poslinkio svorio centro taške kompensavimas}

Ši kompensavimo algoritmo dalis naudoja pagreičio parametrą, gautą iš akcelerometro, sumontuoto svorio centro taške. Signalas filtruojamas žemų dažnių filtru (2.17 formulè), vèliau du kartus atliekama skaitiné integracija (2.18 formulè).

$$
z_{M}(s)=\frac{1}{s+2 \pi f},
$$

čia $S$ - Laplaso transformacijos kintamasis, $f$ - filtruojamas dažnis, Hz.

$$
z_{M}(t)=\iint_{t} \ddot{z}_{M}(t) d t^{2}
$$

čia $z_{M}, \ddot{z}_{M}$ - amortizuotos masès poslinkis ir pagreitis svorio centro vietoje.

\subsubsection{Amortizuotos masès sukimosi apie skersinę ašj kompensavimas}

Ši kompensavimo algoritmo dalis skirta panaikinti sukimosi apie skersinę aši sukuriamus svyravimus. Mikromechaninis jutiklis, sumontuotas svorio centre, matuoja amortizuotos masès sukimosi apie skersinę aši greiti. Atlikus parametro 
skaitinę integraciją (2.19 formulè), gaunamas kampas, kuriuo pasisukusi amortizuota masė tuo laiko momentu. Žinodami atstumą nuo svorio centro iki priekinès ašies ir atstumą nuo priekinès ašies iki lazerinio jutiklio, galime apskaičiuoti, kokị poslinkị reikia kompensuoti iš lazerinio jutiklio signalo (2.20 formulè).

$$
\varphi(t)=\int_{t} \dot{\varphi}(t) d t,
$$

čia $\varphi, \dot{\varphi}$ - sukimosi apie skersinę aši kampas ir greitis.

$$
\Delta z_{\varphi}=l_{\text {laser }} \tan \varphi,
$$

čia $\Delta z_{\varphi}$ - vertikalus amortizuotos masès poslinkis lazerinio jutiklio montavimo vietoje; $l_{\text {laser }}$ - atstumas nuo lazerinio jutiklio iki svorio centro (2.21 formulè).

$$
l_{\text {laser }}=l_{f}+l_{l} \text {. }
$$

čia $l_{f}$-atstumas nuo svorio centro iki priekinès ašies; $l_{l}$-atstumas nuo priekinės ašies iki lazerinio jutiklio.

\subsubsection{Lazerinio jutiklio montavimo padèties kompensavimas}

Paskutiné kompensavimo dalis, atliekanti lazerinio jutiklio montavimo padeties kampo kompensavimą. Ši dalis įtakos turi tada, kai jutiklis montuojamas nestatmenai kelio paviršiui. Nestatmenas montavimo kampas kompensuojamas pagal formulę:

$$
z_{l c}=z_{l} \cos \alpha,
$$

čia $z_{l c}$ - koreguotas lazerinio jutiklio signalas; $z_{l}$ - išmatuotas lazerinio jutiklio signalas, $\alpha$ - lazerinio jutiklio montavimo kampas iki vertikalios keliui ašies.

\subsection{Kompensavimo algoritmo rezultatụ analizè}

Kompensavimo algoritmo modelis sudarytas kompiuteriniu skaičiavimo paketu Matlab/Simulink. Šioje programoje modelis ịvedamas grafinio ir tekstinio programavimo formomis. Sukurtas kompensavimo algoritmo modelis pavaizduotas 2.25 paveiksle. 


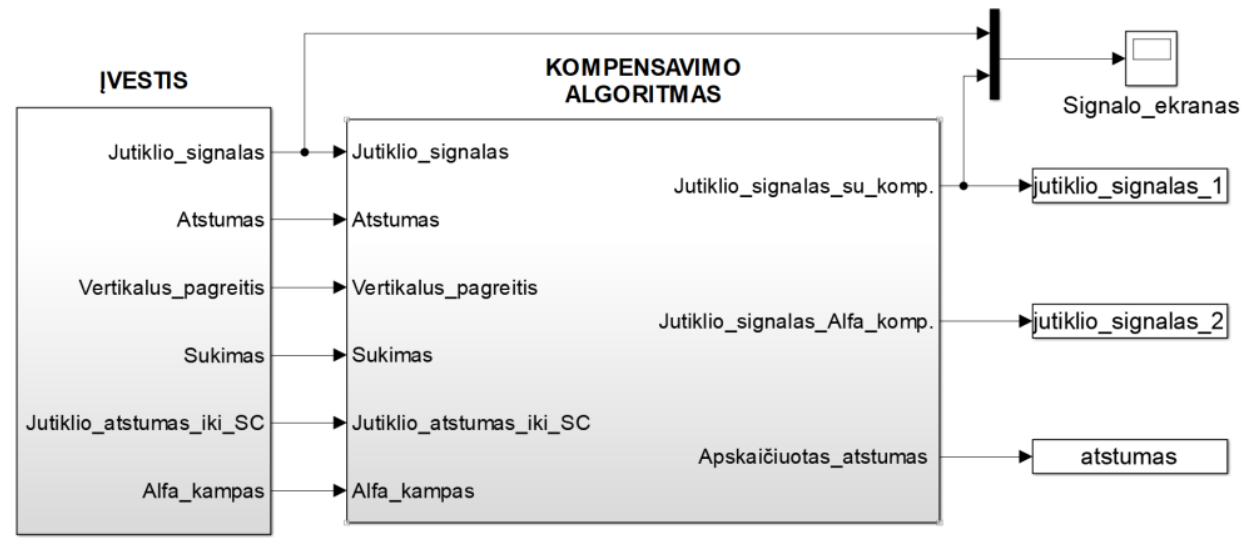

2.25 pav. Amortizuotos masès svyravimo kompensavimo algoritmas

Fig. 2.25. Sprung mass oscillation compensation algorithm

Panaudojus anksčiau aprašyto pusės automobilio dinaminio modelio rezultatus bei gautus rezultatus apdorojus kompensavimo algoritmu, gauti rezultatai pateikti 2.26 paveiksle.

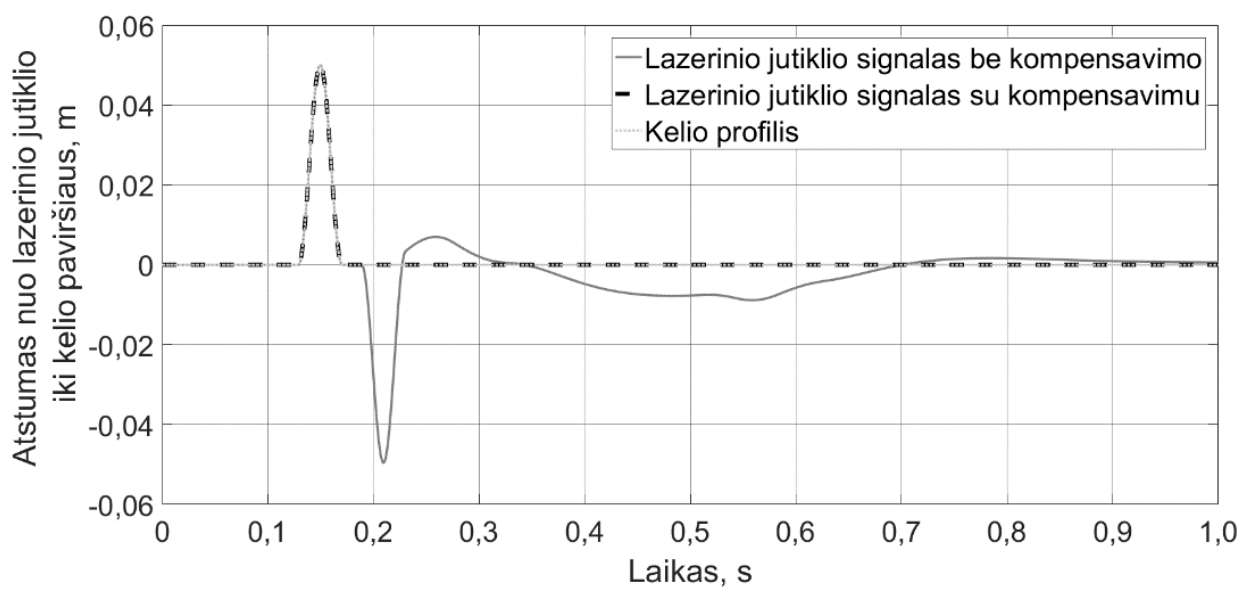

2.26 pav. Modeliuoti lazerinio atstumo jutiklio signalai automobiliui važiuojant per pusès sinusoidès formos kelio nelygumą $30 \mathrm{~km} / \mathrm{h}$ greičiu

Fig. 2.26. Simulated signals of laser height sensor for riding over a half sinusoidal ramp obstacle at $30 \mathrm{~km} / \mathrm{h}$ velocity

Grafike (2.26 pav.) pateikti lazerinio jutiklio signalai su ir be kompensavimo $30 \mathrm{~km} / \mathrm{h}$ važiuojančio automobilio per pusès sinusoidès formos kelio nelygumą. 
Pirmoje signalo dalyje lazerinis jutiklis išmatuoja kelio nelygumą, po to ratas užvažiuoja ant kliūties. Nuvažiuojantis nuo kliūties ratas sukelia amortizuotos masès svyravimus. Jie atsiranda dèl amortizuotos masès sukauptos potencinės energijos. Spyruoklè su amortizatoriumi pamažu slopina svyravimus, kol automobilio kèbulas grịžta i pradinę padètį. Atlikus šio signalo kompensavimą, eliminuojami virpesiai, atsirandantys ratui užvažiuojant ir nuvažiuojant nuo kliūties. Kompensuoto signalo forma identiška įvedamam kelio profiliui. Tai parodo, kad kompensavimo algoritmas teoriniame lygmenyje veikia - nepageidaujami automobilio judesiai panaikinami.

\subsection{Pusiau aktyvios pakabos su nelygumu nustatymu valdymo principu algoritmai}

Kompensavus gauto lazerinio jutiklio signalą (2.10 poskyris) ir žinant realų kelio paviršiaus profilị, galima keisti amortizatorių pasipriešinimo jègą, kad padidètų vairuotojo ir keleivių komfortas, taip pat rato su kelio paviršiumi sąveika.

Žemiau pristatomi sukurti trys algoritmai, leidžiantys pagal iš anksto gautą kompensuotą lazerinio jutiklio signalą keisti pusiau aktyvaus amortizatoriaus pasipriešinimo jègą, taip prisitaikant prie kelio nelygumų. Modeliai kurti Matlab/Simulink aplinkoje, pasipriešinimo ir standumo jëgų kitimas aprašytas netiesinemis funkcijomis (2.2 poskyris), nurodyti amortizatoriaus uždelsimai (2.3 poskyris). Valdymo algoritmo schema pavaizduota 2.27 paveiksle.

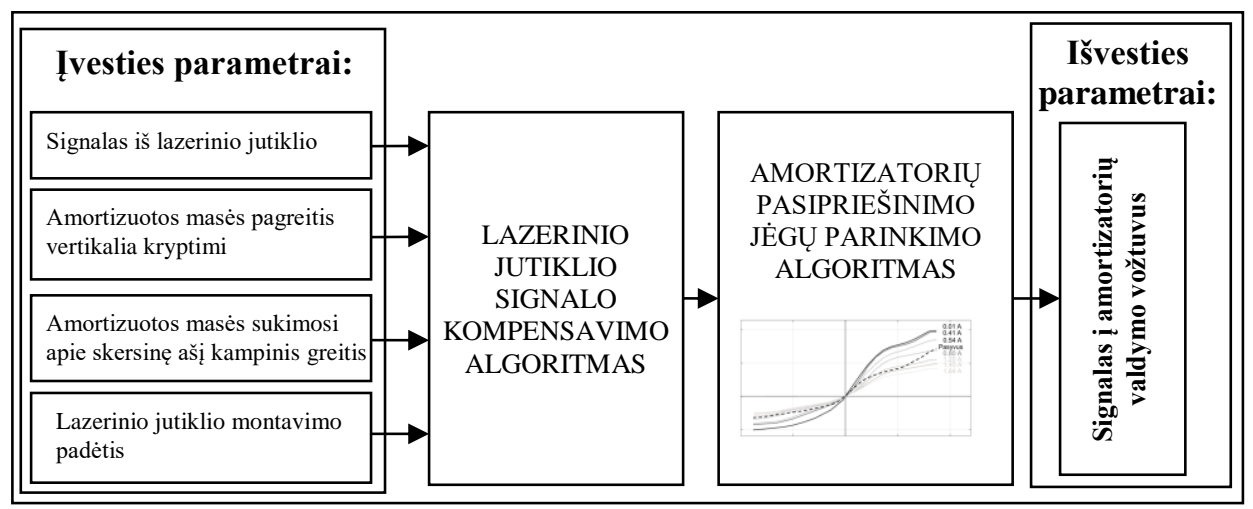

2.27 pav. Pusiau aktyvios pakabos sukurto valdymo algoritmo bendroji schema

Fig. 2.27. Semi-active suspension novel main algorithm scheme 
2.27 paveiksle bendroji algoritmo schema suskirstyta ị atskiras dalis:

- Ivesties parametrai - duomenys apie dinaminius automobilio parametrus realiu laiku. Šie dydžiai gaunami iš pusès automobilio matematinio modelio simuliavimo metu.

- Lazerinio jutiklio signalo kompensavimo algoritmas - algoritmas, aprašytas 2.8 poskyryje, jo reikia siekiant kompensuoti amortizuotos masės svyravimus.

- Amortizatoriaus pasipriešinimo jėgu parinkimo algoritmas - algoritmas, skirtas pagal lazerinio atstumo jutiklio užfiksuotus duomenis parinkti realiu laiku tinkamas amortizatoriaus pasipriešinimo jègas. Naudojami skirtingi trys algoritmai, aprašyti $2.10 .1-2.10 .3$ poskyriuose.

- Signalas ị amortizatorių valdymo vožtuvus - pagal algoritmo veikimą generuojamas signalas ị amortizatorių valdymo vožtuvus.

Tinkamų pasipriešinimo jẻgų parinkimo algoritmai kurti skirtingi, siekiant išrinkti tinkamiausią konkrečiomis sąlygomis.

\subsubsection{Amortizatorių pasipriešinimo jẻgų parinkimo algoritmas pagal nustatytų nelygumų aukšti}

Šis amortizatorių pasipriešinimo jègų parinkimo algoritmas veikia pagal iš anksto parinktą ir nustatytą kelio nelygumo aukštį. 2.28 paveiksle pavaizduota, kokio dydžio nelygumams parenkama pasipriešinimo jègų netiesinè funkcija. Teoriniai tyrimai atlikti su $0,05 \mathrm{~m}$ aukščio kelio nelygumu, todèl šis dydis buvo suskirstytas i dalis (2.28 pav. ašis su užrašu „Nelygumo aukštis“).

Algoritmas pagal nustatytą nelygumo aukšti $z_{l}$ parenka amortizatoriaus pasipriešinimo jègos netiesinę funkciją. Pasikeitus nelygumo aukščiui, keičiama charakteristika. Teoriniuose tyrimuose pasipriešinimo jèga kiekvienu laiko momentu paduodama i pusès automobilio matematini modeli, o realioje sistemoje - i amortizatorių pasipriešinimo jëgų reguliavimo vožtuvus. Vožtuvo atsidarymo laipsnis tiesiogiai priklauso nuo srovès stiprio dydžio:

- kai vožtuvas atidarytas minimaliai - 0,01 A, generuojamos didžiausios amortizatoriaus pasipriešinimo jègos;

- 1,64 A - mažiausios pasipriešinimo jègos, kai amortizatoriaus vožtuvas maksimaliai atidarytas ir hidraulinio skysčio pratekejimo debitas yra didžiausias.

Realioje sistemoje naudojant ši valdymo algoritmą pagal nelygumų aukšti būtina suderinti amortizatorių charakteristikas. 2.28 grafike numatytos reikšmès tinkamos šiame darbe eksperimentiniuose tyrimuose naudotiems ZF Sachs gamintojo amortizatoriams arba kitų gamintojų amortizatoriams, turintiems panašias charakteristikas. Analizuojant rezultatus, šis valdymo algoritmas įvardintas Algoritmas 1 . 


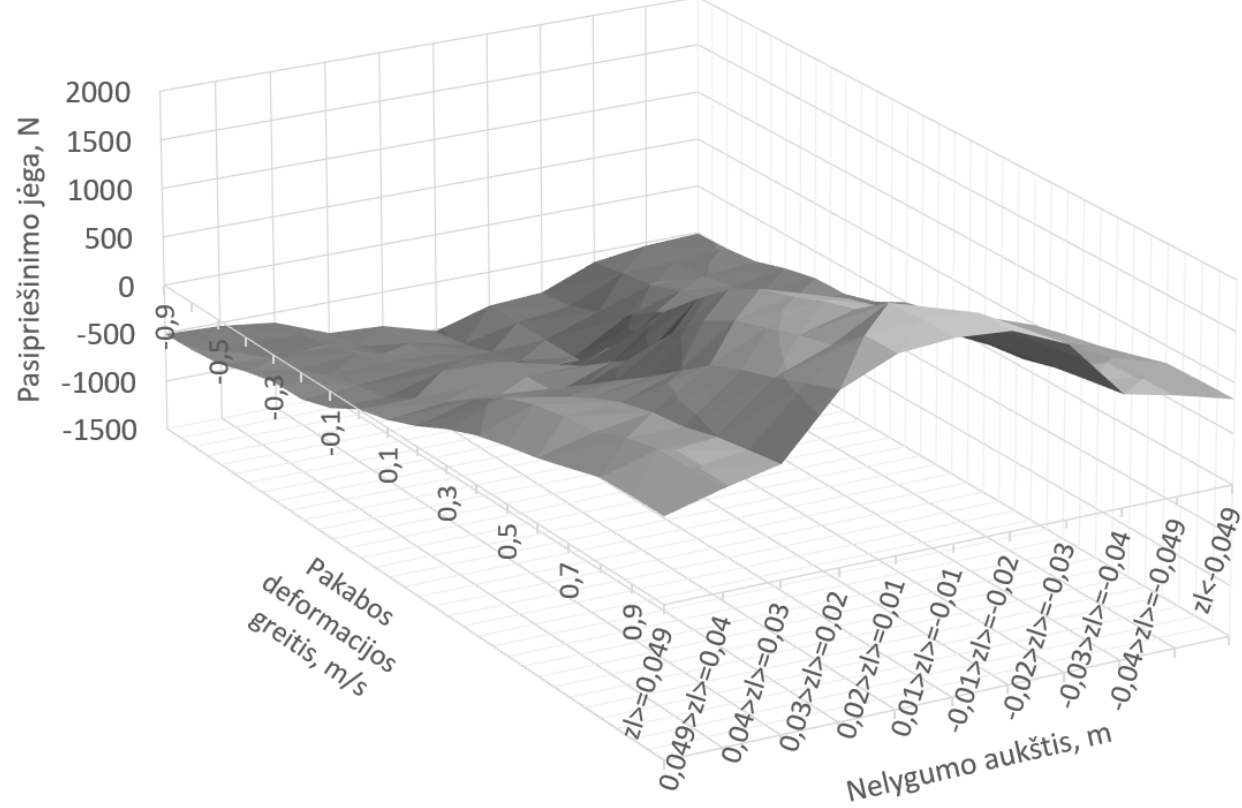

2.28 pav. Pasipriešinimo jėgų parinkimo grafikas pagal kelio nelygumo aukšti

Fig. 2.28. Damping force selection according to irregularity size of road

Maksimalus greitis, kuriuo važiuojant galima suspèti pakeisti amortizatorių slopinimą, yra apskaičiuojamas pagal 2.23 formulę. Lazerinio jutiklio montavimo atstumas nuo priekinès ašies parenkamas $l_{l}=1 \mathrm{~m}$, amortizatorių suveikimo uždelsimas (mechaninis ir elektrinis pagal 2.3 poskyri) $-t_{d}=0,073 \mathrm{~s}$.

$$
v_{\max }=\frac{l_{l}}{t_{d}}=\frac{1}{0,073}=13,7 \mathrm{~m} / \mathrm{s} .
$$

Siekiant, kad šis ar kiti aprašyti algoritmai būtų tinkami, turi būti neviršytas $13,7 \mathrm{~m} / \mathrm{s}(49,3 \mathrm{~km} / \mathrm{h})$ greitis. Antraip amortizatorių norimos pasipriešinimo jègos bus pakeistos per vèlai.

\subsubsection{Amortizatorių pasipriešinimo jėgų parinkimo algoritmas pagal nustatytų nelygumų pobūdị}

Šis amortizatoriaus pasipriešinimo jẻgų parinkimo algoritmas veikia pagal nustatytų nelygumų pobūdị, t. y. nustačius nelygumo didèjimą, ijungiamas minimalus 
slopinimas, mažejant nelygumui - maksimalus slopinimas, esant lygiam kelio paviršiui - vidutinis slopinimas. Algoritme stebimas ne nelygumo aukštis, bet aukščio pokytis - pasikeitimo greitis (2.29 pav.).

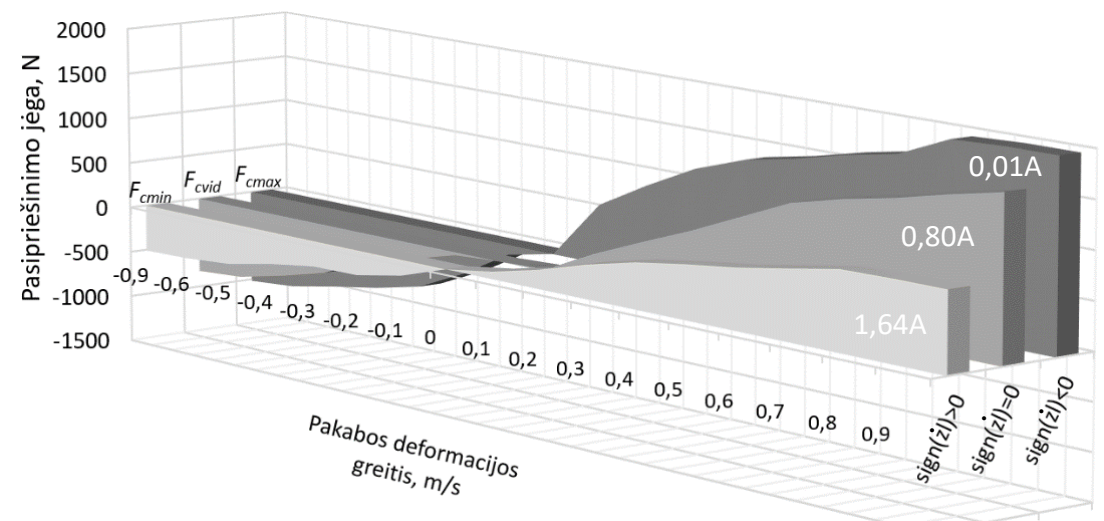

2.29 pav. Pasipriešinimo jègų parinkimo grafikas pagal kelio nelygumo pobūdị

Fig. 2.29. Damping force selection according to irregularity type of road

Algoritmo veikimo sąlygos aprašomos pagal 2.24 formulę:

$$
F_{c}(\Delta \dot{z})= \begin{cases}F_{c \text { min }}, & \operatorname{sign}\left(\dot{z}_{l}\right)>0, \\ F_{c \text { mid }}, & \operatorname{sign}\left(\dot{z}_{l}\right)=0, \\ F_{c \text { max }}, & \operatorname{sign}\left(\dot{z}_{l}\right)<0,\end{cases}
$$

čia $F_{c}$ - pusiau aktyvaus amortizatoriaus pasipriešinimo jèga, $\dot{z}_{l}-$ atstumo nuo kelio paviršiaus iki lazerinio atstumo jutiklio pasikeitimo greitis, $F_{c \max }$-pasipriešinimo jẻgos maksimalios, $F_{c \min }$ - minimalios ir $F_{c v i d}$ - vidutinès reikšmès.

Šio algoritmo privalumas - sistemai nereikia nurodyti ribinio nelygumo aukščio bei nebūtina žinoti sumontuotų amortizatorių charakteristikų. Analizuojant rezultatus, šis valdymo algoritmas ịvardytas Algoritmas 2. Algoritmui taip pat galioja sąlyga, kad automobilio važiavimo greitis turi neviršyti $13,7 \mathrm{~m} / \mathrm{s}$. 


\subsubsection{Amortizatorių pasipriešinimo jẻgụ parinkimo algoritmas pagal maksimalụ nelygumo aukštị ir pobūdį, atsižvelgiant i judèjimo greitị}

Šis algoritmas yra panašus ị anksčiau aprašytus algoritmus pagal užfiksuotų nelygumų aukštị ir pobūdị, tačiau veikiantis papildomomis sąlygomis, susijusiomis su važiavimo greičiu.

Pakabos valdymo sistema, automobiliui važiuojant $13,7 \mathrm{~m} / \mathrm{s}=49,3 \mathrm{~km} / \mathrm{h}$ greičiu, gali pakeisti priekinio rato amortizatoriaus pasipriešinimo jègą. Važiuojant didesniu greičiu, kelio nelygumų matavimas tampa aktualus tik galiniam automobilio ratui.

Algoritmas aprašomas pagal šias veikimo sąlygas:

Amortizatoriaus pasipriešinimo jègos reguliuojamas tik esant didesniems nei 0,02 m kelio nelygumams:

$$
-0,02 \mathrm{~m}<\Delta l_{l}<0,02 \mathrm{~m} \rightarrow F_{c \text { vid }} .
$$

Nelygumų aukštis $0,02 \mathrm{~m}$ pasirinktas, atlikus rezultatų analizę, aprašytą 2.7 poskyryje. Automobiliui važiuojant per $0,02 \mathrm{~m}$ aukščio nelygumus vertikalūs poslinkiai nepersiduoda ị neamortizuotą masę, nes padangos ir kelio paviršiaus kontaktinis plotas yra didelis.

Priekinių amortizatorių pasipriešinimo jègos važiuojant didesniu greičiu nei $13,7 \mathrm{~m} / \mathrm{s}$ reguliuojamas „Skyhook“ valdymo principu:

$$
F_{c}= \begin{cases}F_{c \max }, & \dot{z}_{M}\left(\dot{z}_{M}-\dot{z}_{M 0}\right) \geq 0, \\ F_{c \min }, & \dot{z}_{M}\left(\dot{z}_{M}-\dot{z}_{M 0}\right)<0 .\end{cases}
$$

Galinių amortizatorių pasipriešinimo jègos reguliuojamas pagal lazerinio jutiklio užfiksuotą signalą. Galinès ašies atstumas iki lazerinio jutiklio yra 3,61 m, tai yra pakankamas atstumas, skaičiuojant pagal trukmę, norint pakeisti galinès pakabos amortizatorių pasipriešinimo jègas automobiliui važiuojant 49,5 m/s greičiu.

Didejant nelygumams parenkamas minimalus slopinimas, mažèjant - maksimalus slopinimas:

$$
F_{c}= \begin{cases}F_{c \min }, & \operatorname{sign}\left(\dot{z}_{l}\right)>0, \\ F_{c \max }, & \operatorname{sign}\left(\dot{z}_{l}\right)<0 .\end{cases}
$$

Renkamasi atsižvelgiant ị nelygumų aukščio pokyčio greitị.

Šio valdymo algoritmo privalumas - nereikia nurodyti nelygumų ribinio aukščio, tačiau pritaikius algoritmą kitiems automobiliams pagal ratų bazę ir la- 
zerinio jutiklio montavimo vietą reikia koreguoti kritinị greitį. I algoritmą ịtrauktas „Skyhook“ valdymo principas, kuris eliminuoja klaidingą priekinès pakabos reguliavimą važiuojant greičiau nei $13,7 \mathrm{~m} / \mathrm{s}$. Analizuojant rezultatus, šis valdymo algoritmas įvardytas Algoritmas 3.

\subsection{Pusiau aktyvios pakabos valdymo principu rezultatụ analizè}

Šiame skyriuje atliekama anksčiau aprašytų trijų valdymo algoritmų rezultatų analizè. Rezultatai lyginami su ,Skyhook“valdymo principu ir su pasyvia pakaba.

Bandymo metu automobilis abiem ratais judejo per anksčiau minètą $0,05 \mathrm{~m}$ aukščio kelio nelygumą. Rezultatams palyginti pasirinkti $30 \mathrm{~km} / \mathrm{h} 50 \mathrm{~km} / \mathrm{h}$ (tikslus greitis $13,7 \mathrm{~m} / \mathrm{s}=49,3 \mathrm{~km} / \mathrm{h}$ ) ir $80 \mathrm{~km} / \mathrm{h}$ greitis. Greitis $80 \mathrm{~km} / \mathrm{h}$ pasirinktas kaip nepalankus Algoritmui 1, 2, 3, nes amortizatorius nespeja pakeisti pasipriešinimo jègų. Modeliuojant naudoti automobilio duomenys aprašyti 2.1 poskyryje, 2.1 lenteleje. Naudotas pusės automobilio su lazeriniu atstumo jutikliu matematinis modelis. Standumo ir slopinimo elementų charakteristikos aprašytos netiesinèmis funkcijomis (2.2 poskyris). „Skyhook“ valdymo principas veikè su amortizatorių pasipriešinimo jègu pakeitimo uždelsimu.

Vieni iš svarbiausių analizuojamų kintamujų - amortizuotos masès vertikalus pagreitis ir poslinkis. Šie dydžiai atspindi vairuotojo ir keleivių komfortiškumą. Iš grafikų 2.27 ir 2.28 a) ir b) matyti, kad didžiausias poslinkis yra, kai pakaba pasyvi, vadinasi, turètų būti mažiausias vertikalus pagreitis, tačiau tiek priekinių ratų, tiek galinių ratų, nuvažiuojančių nuo kliūties, pagreitis yra didelis palyginti su Algoritmais 1, 2, 3 ar „Skyhook“ principu. Analizuojant 2.28 a) grafiką, matyti, kad poslinkis mažiausias esant Algoritmui 1 ir „Skyhook“ valdymo principui, kai pasiekus $80 \mathrm{~km} / \mathrm{h}$ greiti ( 2.28 pav. c) didžiausią poslinkị turi amortizatoriai, valdomi Algoritmu 1. Tai ịrodo, kad viršijus nustatytą kritini greiti amortizatorių pasipriešinimo jègos pakeičiamos per vèlai. Važiuojant $30 \mathrm{~km} / \mathrm{h}$ greičiu, pusiau aktyvi pakaba valdoma „Skyhook“ valdymo principu (2.31 pav. a), amortizuota masè 0,4 s greičiau grịžta ị pradinę (poslinkis lygus 0 ) padètį. Didžiausios amplitudès poslinkị po pasyvios pakabos turi pakaba, valdoma Algoritmu 3. „Skyhook“ valdymo principas vertikalaus pagreičio grafike (2.30 pav.) turi staigių pagreičio pokyčių (pažymèta 1 numeriu). Šie pokyčiai atsiranda dèl ị modelị ịvesto amortizatorių dinaminio uždelsimo. Taip pat vertikalaus pagreičio grafike atsispindi $A l$ goritmo 3 ypatybė (pažymėta 2 numeriu), kai nuvažiavusio priekiniu ratu nuo kliūties automobilio amortizuota masè neatlieka papildomų svyravimų. Automobilio su pasyvia pakaba, palyginti su kitais algoritmų poslinkiais, ji yra maždaug $50 \%$ didesnè važiuojant $30 \mathrm{~km} / \mathrm{h}$ ir $50 \mathrm{~km} / \mathrm{h}$ greičiu (2.31 pav. a ir b). Didžiausia 
poslinkių amplitudė matoma automobiliui galiniais ratais pervažiuojant per nelygumą. Taigi, galima daryti išvadą, kad slopinimo elementų reikšmių keitimas realiu laiku turi teigiamą poveikị amortizuotos masès dinamikai.

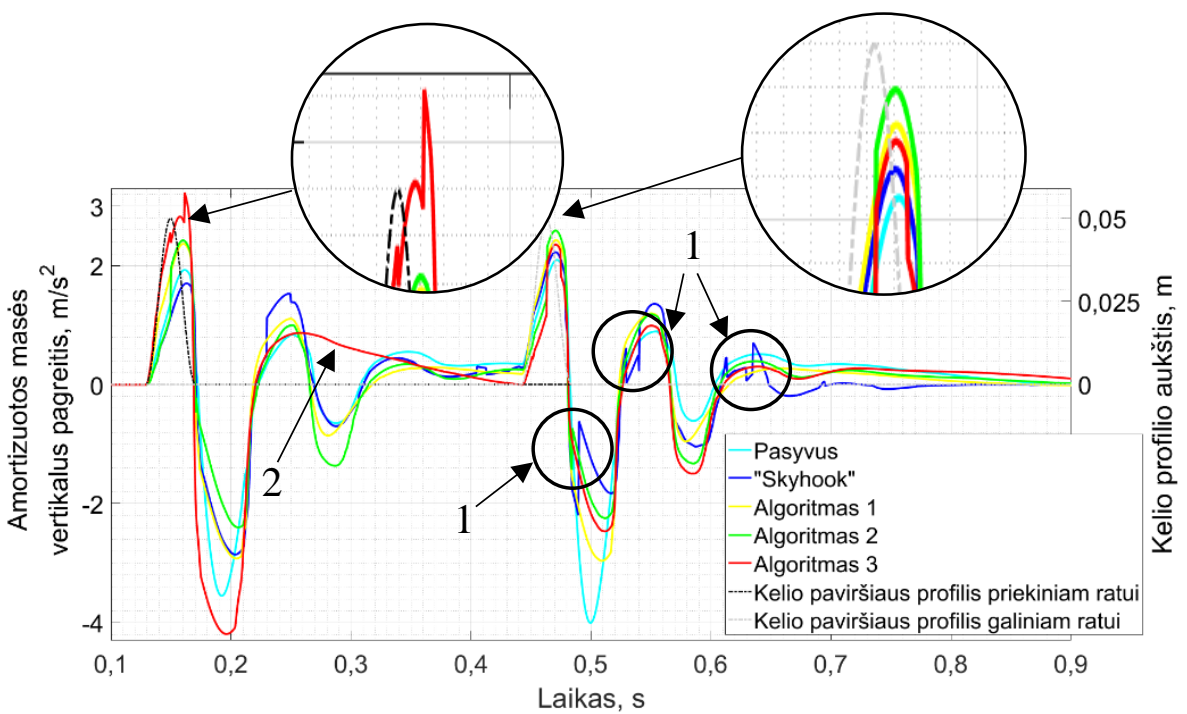

2.30 pav. Amortizuotos masės vertikalus pagreitis, kai pakaba pasyvi, valdoma „Skyhook“ principu ir aprašytais algoritmais važiuojant $30 \mathrm{~km} / \mathrm{h}$ greičiu.

Fig. 2.30. Sprung mass vertical acceleration with passive, "Skyhook" control and described algorithms at $30 \mathrm{~km} / \mathrm{h}$ velocity

Analizuojant amortizuotos masès vertikalų poslinkị svorio centro taške (2.31 pav. a), matyti skirtumai tarp visų bandytu pakabų ir valdymo principų. Didžiausias poslinkis, kai automobilis priekiniu ir galiniu ratais pervažiuoja kelio nelygumą. Automobilio su pasyvia pakaba poslinkis žemyn yra apie $0,011 \mathrm{~m}$ važiuojant $30 \mathrm{~km} / \mathrm{h}$ greičiu. ,Skyhook“ ir Algoritmas 1 poslinkių amplitudė yra panaši, tačiau skirtumas yra, kai priekinis ratas nuvažiuoja nuo kliūties - amortizatoriams, valdomiems „Skyhook“ algoritmu, yra mažesni poslinkiai (pažymèta 1 numeriu 2.31 pav. a), prieš užvažiuojant su galiniu ratu ant kliūties, amortizatorių valdymo Algoritmas 1 turi mažesnị poslinkị (pažymèta 2 numeriu 2.31 pav. a). 


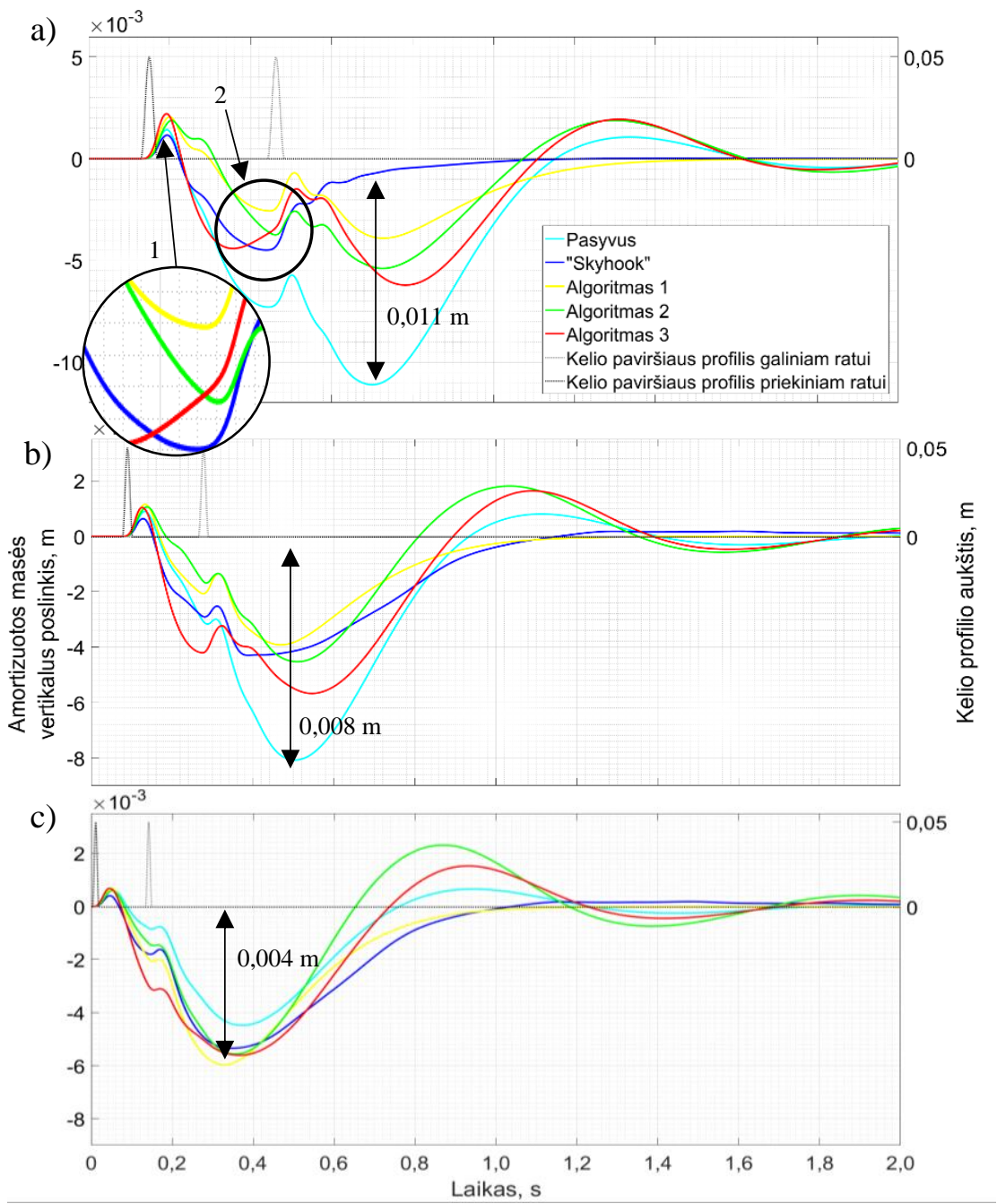

2.31 pav. Amortizuotos masės vertikalus poslinkis, kai pakaba pasyvi, valdoma „Skyhook“ principu ir aprašytais algoritmais: a) važiuojant $30 \mathrm{~km} / \mathrm{h}$;

b) važiuojant $50 \mathrm{~km} / \mathrm{h}$; c) važiuojant $80 \mathrm{~km} / \mathrm{h}$ greičiu.

Fig. 2.31. Sprung mass vertical displacement with passive, "Skyhook" control and described algorithms: a) at $30 \mathrm{~km} / \mathrm{h}$; b) $50 \mathrm{~km} / \mathrm{h}$; c) $30 \mathrm{~km} / \mathrm{h}$ velocities

Automobilio judèjimas dideliu greičiu $(80 \mathrm{~km} / \mathrm{h})$ įrodo pusiau aktyvios pakabos trūkumus. Mažiausias amortizuotos masès poslinkis yra automobilio su pasy- 
via pakaba (2.31 pav. c). Algoritmy 1, 2, 3 ir „Skyhook“ valdymo principo poslinkiai pasiekus $80 \mathrm{~km} / \mathrm{h}$ greitị yra panašūs - apie 5-6 m/s $\mathrm{s}^{2}$, tačiau svyruoja trumpiausiai pakabos, valdomos „Skyhook“ ir Algoritmu 1.

Sukimosi apie skersinę aši kampas (2.32 pav.) yra mažiausias naudojant $A l$ goritma 1 - svyravimų amplitude siekia nuo $-0,2^{\circ}$ iki $0,14^{\circ}$, esant pasyviai pakabai amplitude yra nuo $-0,35^{\circ}$ iki $0,47^{\circ}$. Sukimas apie skersinę aši trunka trumpiausiai esant „Skyhook“ valdymo principui, tačiau priekiniu ratu nuvažiavus nuo nelygumo, kampas yra didžiausias lyginant visus algoritmus. Algoritmas $1 \mathrm{ir} A l$ goritmas 2 svyravimai trunka ilgiau apie $0,6 \mathrm{~s}$ palyginti su Algoritmas 1.

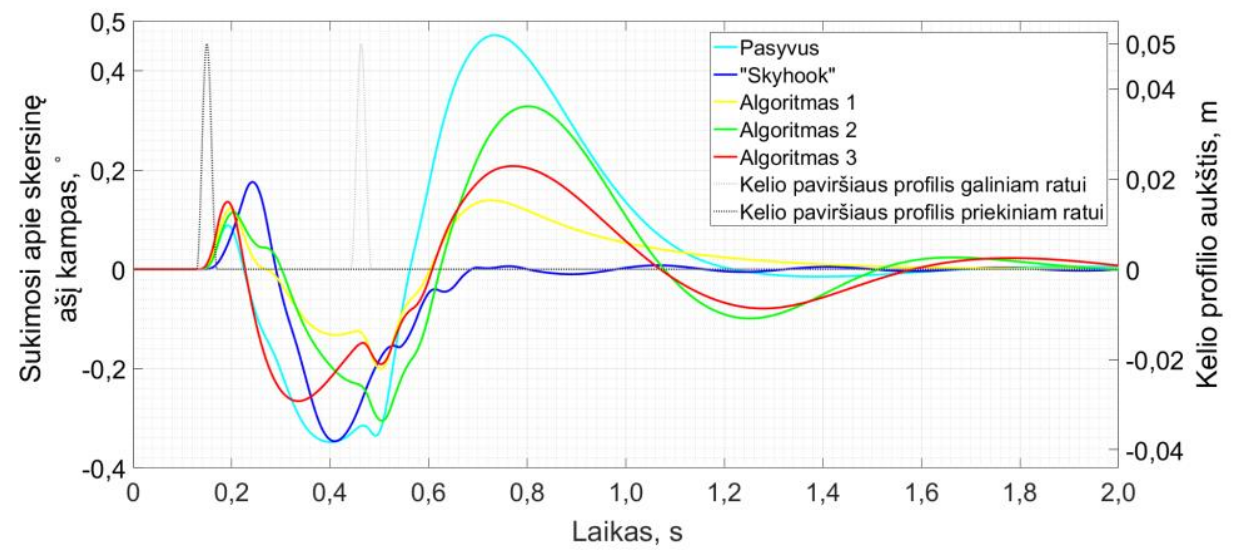

2.32 pav. Sukimasis apie skersinę ašį, kai pakaba pasyvi, valdoma „Skyhook“ principu ir aprašytais algoritmais, o greitis $30 \mathrm{~km} / \mathrm{h}$

Fig. 2.32. Pitch with passive, "Skyhook" control and described algorithms at $30 \mathrm{~km} / \mathrm{h}$ velocity

Pasiekus $50 \mathrm{~km} / \mathrm{h}$ greitị sukimosi apie skersinę aši kampo tendencijos išlieka panašios (2.33 pav.). Didžiausias matomas skirtumas - pakabos valdomos „Skyhook“ svyravimų apie skersinę aši padidèjimas. $50 \mathrm{~km} / \mathrm{h}$ greitis yra per didelis pusiau aktyvių amortizatorių valdymui. Pasipriešinimo jègos yra pakeičiamos per vẻlai, tai lemia ne svyravimų apie skersinę ašị sumažejimą, o padidèjimą. $\mathrm{Pu}-$ siau aktyvių amortizatorių valdymas Algoritmu 1 yra tinkamas, kai maksimalus nustatytas greitis $-50 \mathrm{~km} / \mathrm{h}$, nes amortizuotos masès sukimo apie skersinę aši kampas ir mažas - apie $0,2^{\circ}$. 


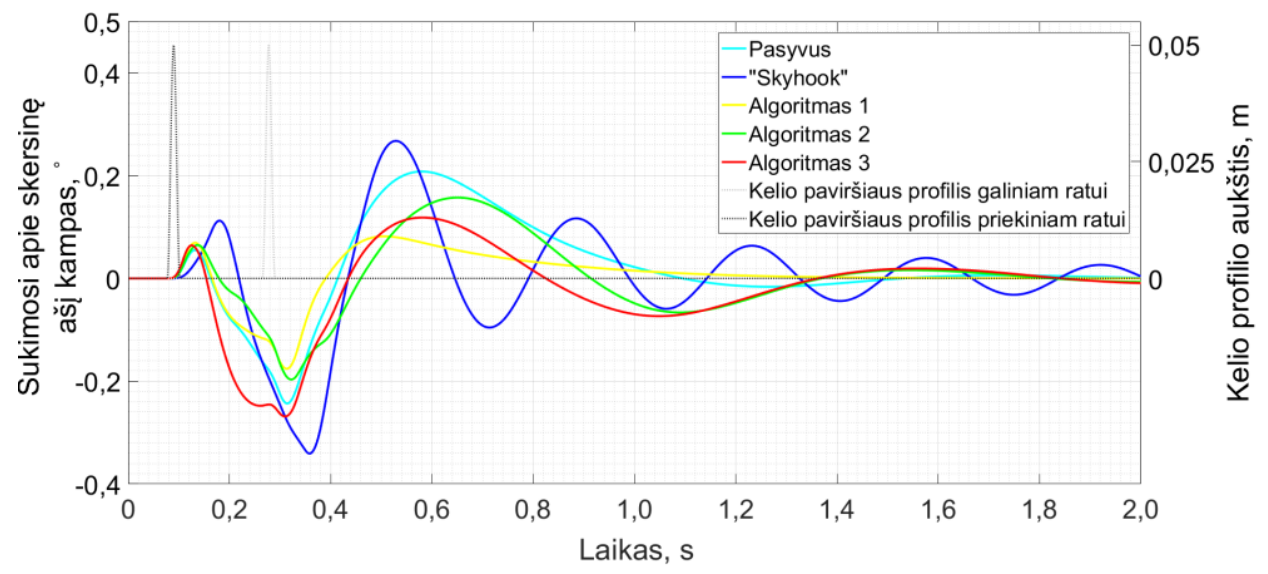

2.33 pav. Sukimasis apie skersinę ašį, kai pakaba pasyvi, valdoma „Skyhook“ principu ir aprašytais algoritmais, o greitis $50 \mathrm{~km} / \mathrm{h}$

Fig. 2.33. Pitch with passive, "Skyhook" control and described algorithms at $50 \mathrm{~km} / \mathrm{h}$ velocity

1.2 poskyryje rašyta, kad „Skyhook“ valdymo principo trūkumai būdingi neamortizuotai masei. Tai matyti iš 2.34 ir 2.35 paveikslų. Didžiausias priekinio rato vertikalus teigiamas poslinkis automobiliui važiuojant $50 \mathrm{~km} / \mathrm{h}$ yra „Skyhook“ principu valdomos pakabos. Visu, išskyrus „Skyhook“" valdomais amortizatoriais, neamortizuotos priekinès masès svyravimai nuslopinami per maždaug $0,4 \mathrm{~s}$ $(\delta=1,77 \div 2,64)$ skaičiuojant nuo nelygumo pabaigos, tai yra gerokai trumpesnis laiko tarpas nei pakabai valdomai „Skyhook“ $(\delta=2,71)$.

Automobiliui su amortizatoriais, valdomais Algoritmu 3, yra mažiausias poslinkis teigiama ir neigiama kryptimis priekiniam ratui - svyravimų amplitudè yra nuo $-0,004 \mathrm{~m}$ iki $0,03 \mathrm{~m}$, svyravimai neturi teigiamo poslinkio ratui nuvažiavus nuo kliūties. Neamortizuotos priekinès masès dinamikai Algoritmas 3 yra tinkamiausias.

Galinès ašies rato (2.35 pav.) vertikalus poslinkis yra mažiausias esant Algoritmu 1 valdomai pakabai, taip pat nèra teigiamo poslinkio ratui nuvažiavus nuo kliūties. Svyravimų neigiamas poslinkis didžiausias pakabai, valdomai Algoritmu 2 ir Algoritmu 3. 


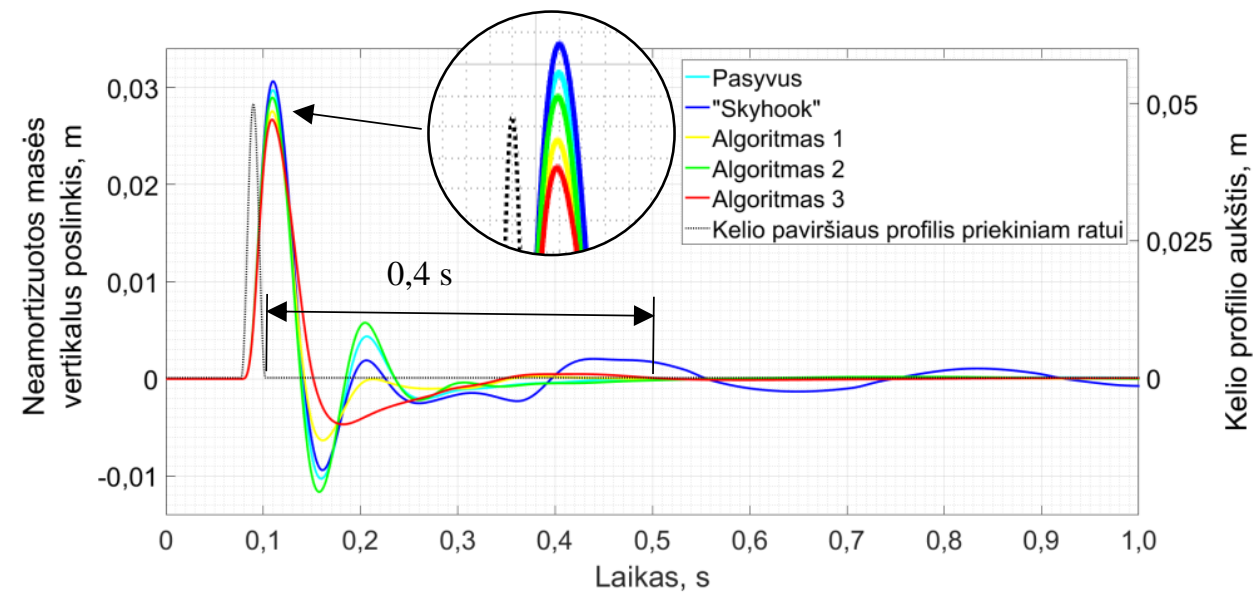

2.34 pav. Priekinès ašies neamortizuotos masès vertikalus poslinkis, kai pakaba pasyvi, valdoma „Skyhook“ principu ir aprašytais algoritmais, o greitis $50 \mathrm{~km} / \mathrm{h}$

Fig. 2.34. Unsprung front axle mass vertical displacement with passive, "Skyhook" control and described algorithms at $50 \mathrm{~km} / \mathrm{h}$ velocity

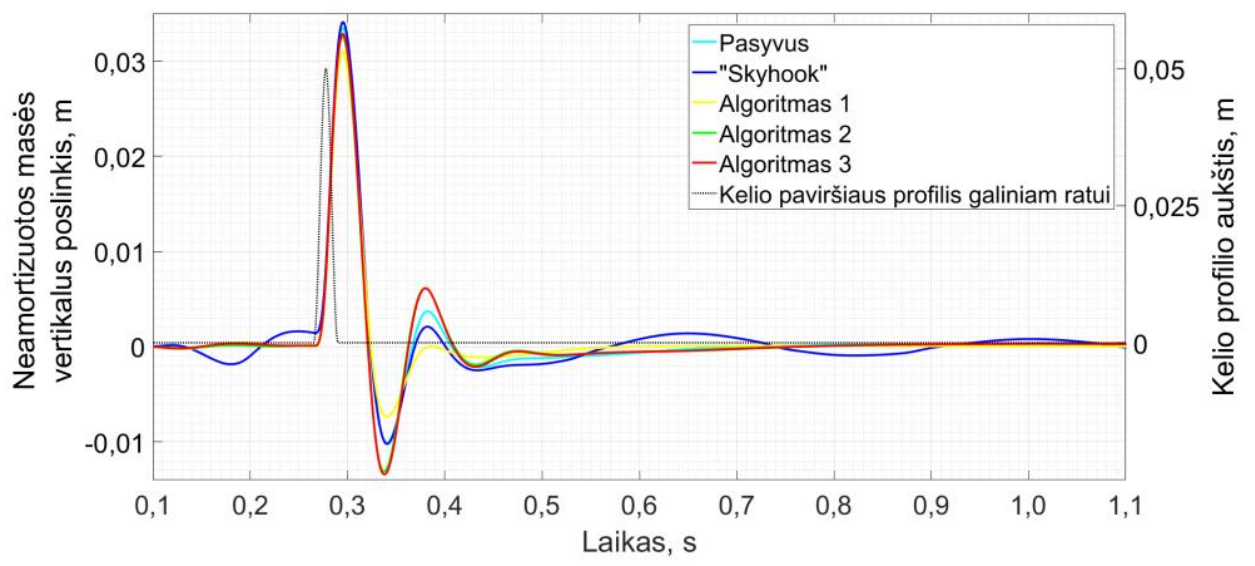

2.35 pav. Galinès ašies neamortizuotos masès vertikalus poslinkis, kai pakaba pasyvi, valdoma „Skyhook“ principu ir aprašytais algoritmais. o greitis $50 \mathrm{~km} / \mathrm{h}$

Fig. 2.35. Unsprung rear axle mass vertical displacement with passive, "Skyhook" control and described algorithms at $50 \mathrm{~km} / \mathrm{h}$ velocity 
Dar vienas svarbus parametras analizuojamas 2.36 ir 2.37 paveiksluose priekinès ir galinès pakabos eigos greitis. Mažiausias pakabos eigos greitis priekinejje ašyje yra pasirinkus amortizatorius, valdomus Algoritmu 3 - eigos greitis yra beveik $1 \mathrm{~m} / \mathrm{s}$ mažesnis nei Algoritmu 2 ar „Skyhook“"valdymo principais. Taip pat ir svyravimai trunka $0,15 \mathrm{~s}$ trumpiau - „Skyhook“ logaritminis dekrementas $\delta=1,71$, Algoritmas $1 \delta=3,91$, Algoritmas 2 .

Galinès pakabos greitis mažiausias esant Algoritmui 1, didžiausias „Skyhook“" valdymo principui, o svyravimai trunka $0,1 \mathrm{~s}$ trumpiau.

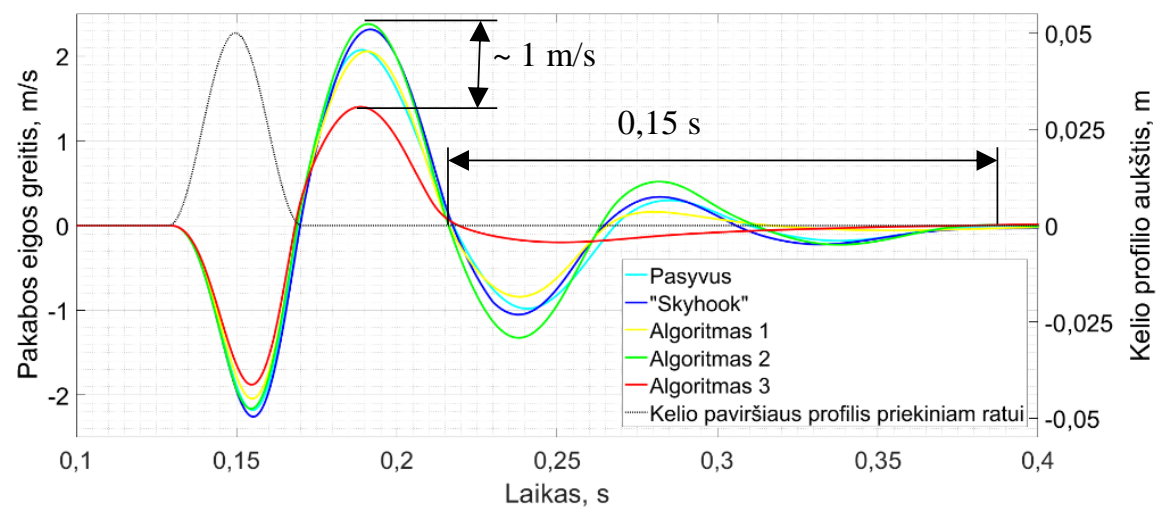

2.36 pav. Priekinès ašies vertikalus greitis, kai pakaba pasyvi, valdoma „Skyhook“ principu ir naujai aprašytais algoritmais, o greitis $30 \mathrm{~km} / \mathrm{h}$

Fig. 2.36. Front axle vertical velocity with passive, "Skyhook" control and described algorithms at $30 \mathrm{~km} / \mathrm{h}$ velocity

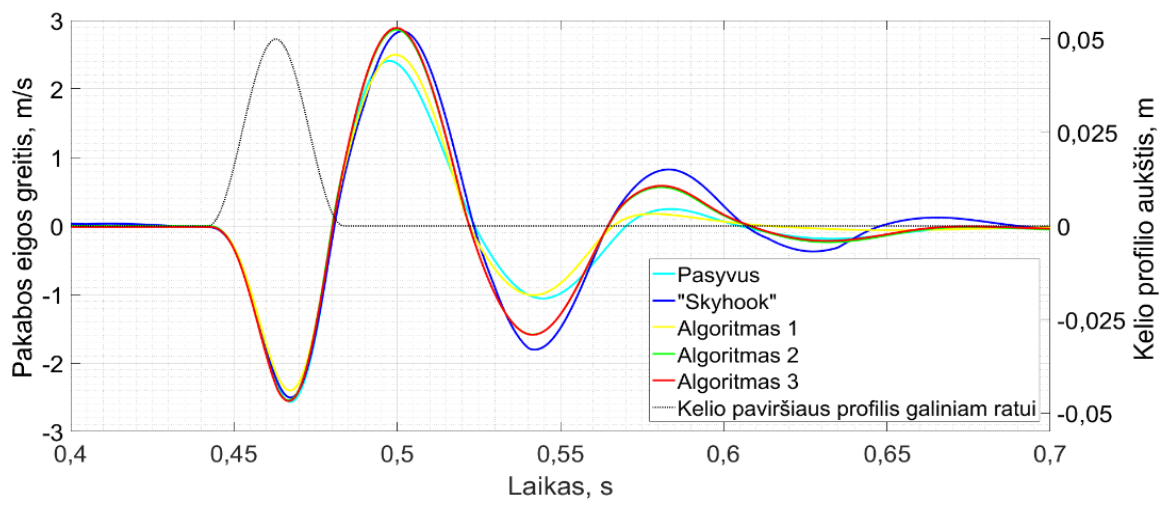

2.37 pav. Galinès ašies vertikalus greitis, kai pakaba pasyvi, valdoma „Skyhook“ principu ir aprašytais algoritmais, o greitis $30 \mathrm{~km} / \mathrm{h}$

Fig. 2.37. Rear axle vertical velocity with passive, "Skyhook" control and described algorithms at $30 \mathrm{~km} / \mathrm{h}$ velocity 
Apžvelgus simuliavimo rezultatus, matyti, kad 2.10.1-2.10.3 aprašyti pusiau aktyvios pakabos valdymo algoritmai turi privalumų ir trūkumų skirtingoms neamortizuotoms ir amortizuotai masėms. Vienareikšmiškai matyti, kad algoritmai turi pranašumą prieš pasyvią pakabą - mažesni amortizuotos masès pagreičiai ir poslinkiai vertikalia kryptimi. Taip pat matomi valdymo algoritmu privalumai, palyginti su ,Skyhook“ valdymo principu, kintant neamortizuotai masei.

\subsection{Valdymo principu apibendrinimas}

2.11 poskyryje atlikta matematinio modeliavimo rezultatų analizè atskleidè skirtingų algoritmų ypatybes vieniems ar kitiems dinaminiams veiksniams. Siekiant išrinkti geriausią algoritmą, rezultatai apdorojami apskaičiuojant:

- vidutinę kvadratinę paklaidą;

- amortizuotos masès poslinkio ir sukimosi apie skersinę aši kampo svyravimų nusistovèjimo trukmę;

- amortizuotos ir neamortizuotos masès pagreičio maksimalias ir minimalias amplitudes;

- pakabos eigos greičių maksimalias ir minimalias amplitudes.

Svyravimų nusistovèjimo trukmè fiksuojama pasiekus $2 \%$ ribą iki nulinès reikšmès skaičiuojant nuo maksimalios ir minimalios amplitudès reikšmių. Rezultatams apibendrinti pasirinktas automobilio judejimas pastoviu $30 \mathrm{~km} / \mathrm{h}$ greičiu. Rezultatai suvesti ị 2.5 lentelę. Siekiant lengviau orientuotis lentelèje, kai kuriụ reikšmių langeliai paryškinti. Paryškinimas susijęs su geriausiomis reikšmėmis tarp algoritmų: RMS, MAX, Laikas - mažiausios, MIN - didžiausios reikšmès.

2.5 lentelè. Pusiau aktyvios pakabos valdymo principų suvestinè

Table 2.5. Summary of semi-active suspension controls

\begin{tabular}{|c|c|c|c|c|c|c|c|}
\hline \multicolumn{3}{|c|}{ Parametras } & 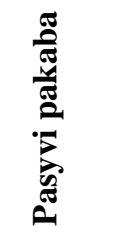 & 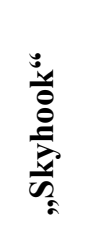 & 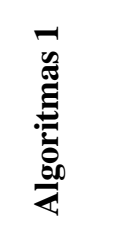 & 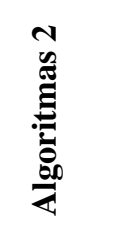 & 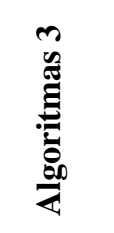 \\
\hline \multicolumn{3}{|c|}{1} & 2 & 3 & 4 & 5 & 6 \\
\hline \multirow{3}{*}{$\ddot{z}_{M}$} & $R M S$ & & 0,428 & 0,360 & 0,415 & 0,364 & 0,482 \\
\hline & $M I N$ & \multirow{2}{*}{$\mathrm{m} / \mathrm{s}^{2}$} & $-4,005$ & $-2,855$ & $-2,962$ & $-2,399$ & $-4,192$ \\
\hline & MAX & & 2,098 & 2,228 & 2,431 & 2,592 & 3,227 \\
\hline
\end{tabular}


2.5 lentelès pabaiga

\begin{tabular}{|c|c|c|c|c|c|c|c|}
\hline \multicolumn{3}{|c|}{1} & 2 & 3 & 4 & 5 & 6 \\
\hline \multirow[b]{2}{*}{$z_{M}$} & \multicolumn{2}{|l|}{$R M S$} & 0,00304 & 0,000867 & 0,00102 & 0,00148 & 0,00174 \\
\hline & Laikas & $\mathrm{S}$ & 2,394 & 0,965 & 2,403 & 2,905 & 2,360 \\
\hline \multirow{2}{*}{$\varphi$} & $R M S$ & & 0,124 & 0,0588 & 0,0434 & 0,0877 & 0,0706 \\
\hline & Laikas & $\mathrm{S}$ & 1,424 & 1,398 & 1,457 & 2,072 & 2,352 \\
\hline \multirow{3}{*}{$\ddot{Z}_{m f}$} & $R M S$ & & 26,68 & 28,61 & 25,40 & 29,14 & 20,59 \\
\hline & $M I N$ & \multirow{2}{*}{$\mathrm{m} / \mathrm{s}^{2}$} & $-224,0$ & $-228,0$ & $-217,0$ & $-226,4$ & $-206,2$ \\
\hline & $M A X$ & & 146,7 & 149,2 & 140,5 & 149,2 & 131,1 \\
\hline \multirow{3}{*}{$\ddot{z}_{m r}$} & $R M S$ & & 54,62 & 62,21 & 53,40 & 61,09 & 61,39 \\
\hline & $M I N$ & \multirow{2}{*}{$\mathrm{m} / \mathrm{s}^{2}$} & $-300,7$ & $-289,8$ & $-288,7$ & $-301,1$ & $-293,0$ \\
\hline & $M A X$ & & 177,7 & 191,0 & 170,3 & 183,1 & 184,2 \\
\hline \multirow{3}{*}{$\Delta \dot{z}_{f}$} & $R M S$ & & 0,201 & 0,217 & 0,190 & 0,226 & 0,142 \\
\hline & $M I N$ & \multirow{2}{*}{$\mathrm{m} / \mathrm{s}$} & $-2,178$ & $-2,256$ & $-2,044$ & $-2,162$ & $-1,878$ \\
\hline & $M A X$ & & 2,073 & 2,315 & 2,056 & 2,379 & 1,401 \\
\hline \multirow{3}{*}{$\Delta \dot{z}_{r}$} & $R M S$ & & 0,221 & 0,262 & 0,218 & 0,256 & 0,257 \\
\hline & $M I N$ & \multirow{2}{*}{$\mathrm{m} / \mathrm{s}$} & $-2,566$ & $-2,505$ & $-2,401$ & $-2,543$ & $-2,555$ \\
\hline & $M A X$ & & 2,408 & 2,842 & 2,499 & 2,865 & 2,887 \\
\hline
\end{tabular}

2.38 paveikslo rezultatai pateikti grafiškai: a) dalyje pateiktos amortizuotos ir neamortizuotu masių pagreičiu vidutinès kvadratinės paklaidos. Mažiausia RMS reikšmè priekinei neamortizuotai masei yra su Algoritmu 3. Galinei ašiai pasyvi pakaba ir Algoritmas 1 RMS yra mažiausi ir labai artimi. Amortizuotai masei mažiausias RMS, kai pakaba veikia „Skyhook“ valdymo principu, nedaug atsilieka Algoritmas 2, taip pat šis algoritmas turi mažiausią svyravimų amplitudę amortizuotai masei judant žemyn (2.5 lentelè). Amortizuotos masès poslinkis ir nusistovejjimo laikas (2.38 pav. b) yra mažiausias „Skyhook“ valdymo principui, sukurtų algoritmų poslinkis mažiausias esant Algoritmui 1. Sukimosi apie skersinę aši kampo RMS yra mažiausia Algoritmui 1 (2.38 pav. c), pasyvios pakabos RMS yra didžiausia, tačiau nusistovejjimo laikas yra mažiausias esant „Skyhook“. Priekinès ir galinès pakabos eigos greičiai yra mažiausi esant Algoritmui 1 (2.38 pav. d). 


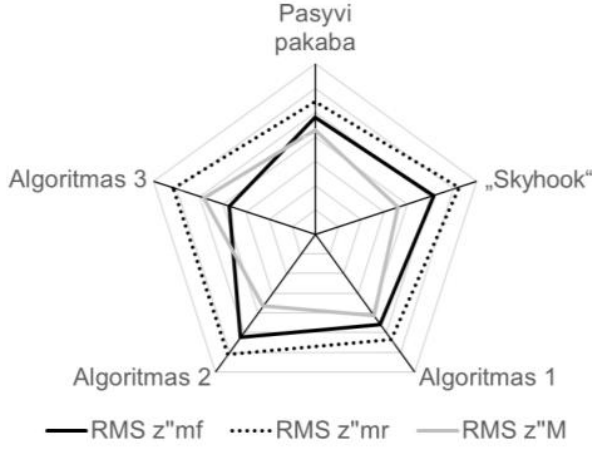

a)

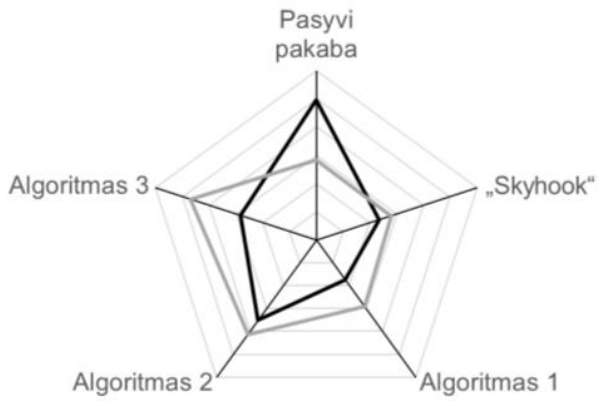

c)

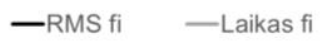

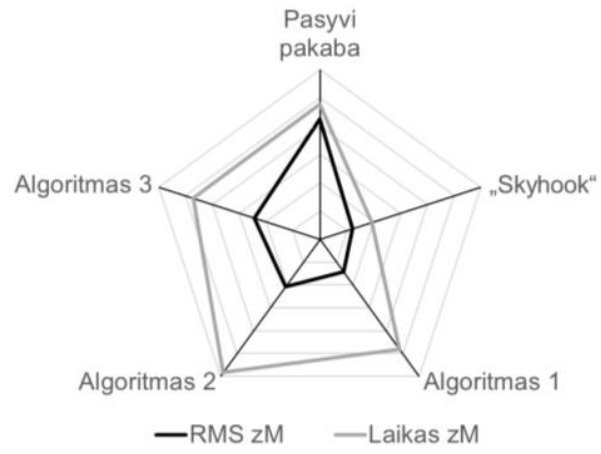

b)

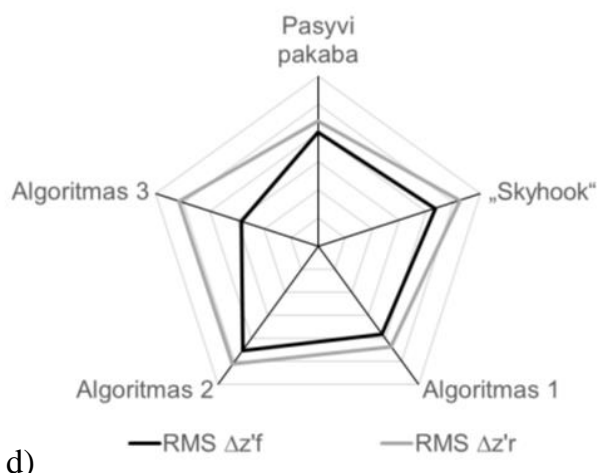

2.38 pav. Skirtingų dinaminių veiksnių grafikai: a) amortizuotos ir neamortizuotos masès vertikalaus pagreičio vidutinio kvadratinio nuokrypio reikšmės; b) amortizuotos masès vertikalaus poslinkio vidutinis kvadratinis nuokrypis ir svyravimų nusistovejjimo laikas; c) amortizuotos masès sukimosi apie skersinę aši kampo vidutinis kvadratinis nuokrypis ir nusistovejjimo laikas; d) priekinès ir galinès ašių vertikalaus greičio vidutinio kvadratinio nuokrypio reikšmès

Fig. 2.38. Graphs of different dynamic indicators: a) root mean square values of sprung and unsprungs masses vertical acceleration; b) root mean square of sprung mass vertical displacement and oscillation settling time; c) root mean square of pitch angle and settling time; $d$ ) root mean square values of front and rear axles vertical velocities

Apibendrinantis valdymo principu grafikas pateiktas 2.39 paveiksle. Pakabos, veikiančios Algoritmu 2, rezultatai panašūs kaip ,Skyhook“ valdymo principu. ,Skyhook“ privalumai amortizuotai masei. 


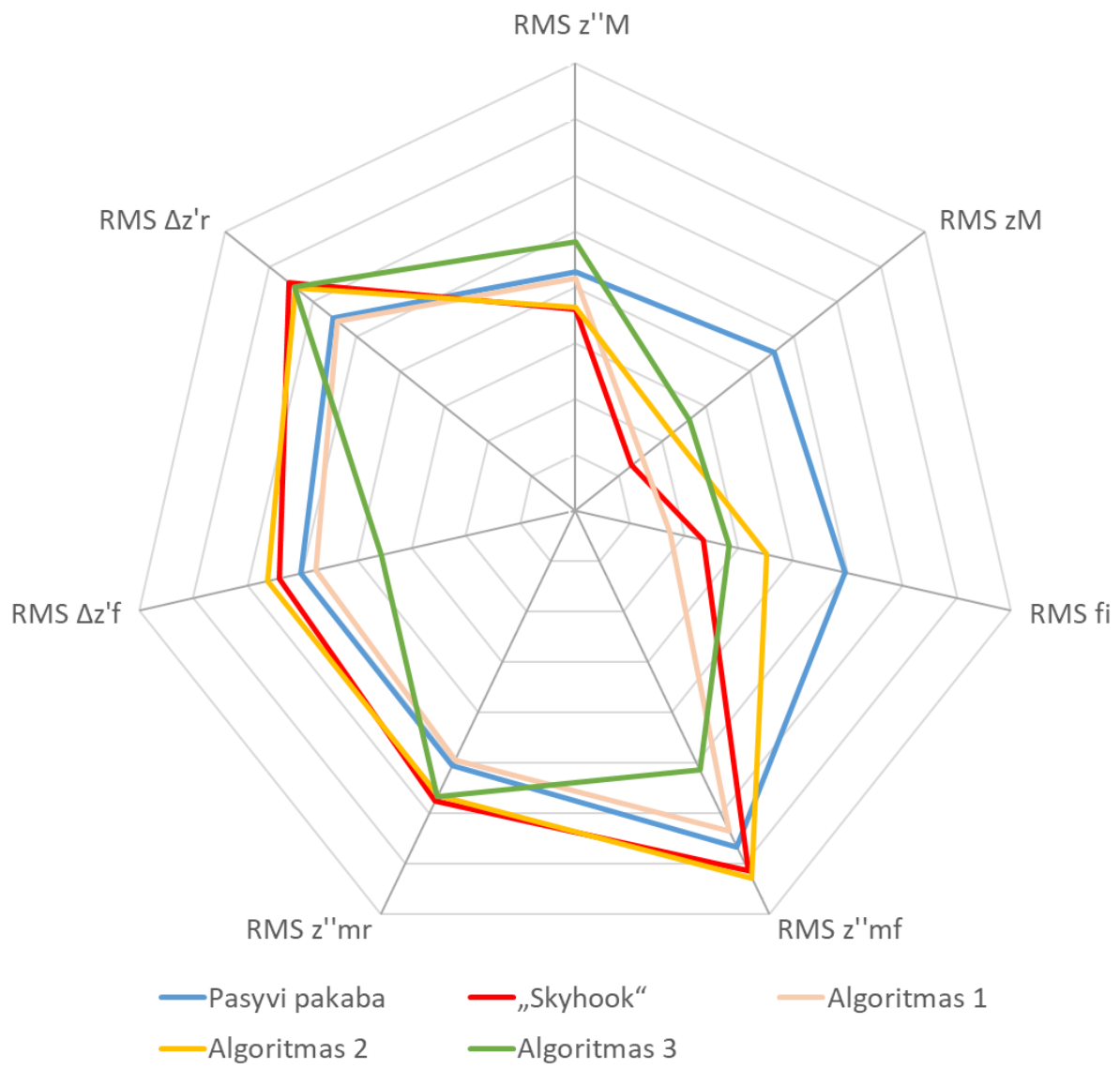

2.39 pav. Skirtingų rodiklių vidutinio kvadratinio nuokrypio reikšmės esant bandytiems pakabų valdymo algoritmams

Fig. 2.39. Root mean square values of different indicators in tested suspension control algorithms

Geriausiai veikiantis iš sukurtų algoritmų yra Algoritmas 1 (2.39 pav.). Automobilio su pusiau aktyvia pakaba, valdoma Algoritmu 1, amortizuotos masès sukimosi apie skersinę ašį kampas yra mažiausias, maži neamortizuotų masių vertikalūs pagreičiai. Poslinkis vertikalia kryptimi mažas, palyginti su kitais valdymo algoritmais. Galime teigti, kad Algoritmas 1 orientuotas ị rato ir kelio paviršiaus kontakto gerinimą, taip pat važiavimo komfortas yra didelis. Naudojant Algoritma 2 yra didelis sukimosi apie skersinę ašį kampas, priekinès ir galinès pakabos eigos greitis. Algoritmo 3 privalumai matomi priekinès ašies dinamikai, o trūkumai - galinès neamortizuotos masès pagreičiui bei amortizuotos masès dinamikai. 


\subsection{Antrojo skyriaus išvados}

1. Norint, kad matematinis modelis būtų panašus ị tikrą sistemą, būtina aprašyti standumo ir slopinimo elementus netiesinèmis funkcijomis bei įtraukti slopinimo elementų veikimo uždelsimą, nes šie dydžiai turi įtakos gaunamiems rezultatams. Tyrimuose naudotų amortizatorių veikimo uždelsimas yra 73 ms.

2. Kelio paviršiaus nustatymas prieš rato užvažiavimą leidžia išvengti slopinimo elementų veikimo uždelsimo keičiant amortizatoriaus pasipriešinimo jègą. Maksimalus greitis, kai pakeičiama norima pasipriešinimo jẻga, yra 13,7 m/s, o lazerinis jutiklis pritvirtintas $1 \mathrm{~m}$ atstumu nuo priekinès ašies.

3. Atlikta analizè parodè, kad, atsižvelgiant ị nelygumo dydị, reikia keisti amortizatorių pasipriešinimo jègą, norint pagerinti važiavimo komfortą ir išlaikyti rato ir kelio sąveiką. Automobilis užvažiuoti ant kliūties turi su minimaliu amortizatorių slopinimu, o nuvažiuoti nuo kliūties su dideliu slopinimu, nes tuomet amortizuotos masès svyravimų amplitudė vertikalia kryptimi yra mažesnè.

4. Lyginant pusiau aktyvią, valdoma „Skyhook“ principu, ir pasyvia pakabas, pastebèta: amortizuotos masès poslinkis (,Skyhook“) yra iki šešių kartų mažesnis, kai greitis $30 \mathrm{~km} / \mathrm{h}$, vertikalaus pagreičio amplitudè viso bandymo metu yra mažesnè, sukimosi apie skersinę ašį kampas yra nuo $0,26^{\circ}$ iki $0,41^{\circ}$ mažesnis, palyginti su pasyvia pakaba.

5. Automobilio pusiau aktyvi pakaba valdoma aprašytais algoritmais, turi mažesnị neamortizuotos masès pagreitį, tačiau amortizuotos masès pagreitis ir poslinkis yra mažesnis pakabai, valdomai „Skyhook“ valdymo principu.

6. Išrinktas geriausias valdymo principas yra Algoritmas 1, nes šis algoritmas bandymų metu turèjo mažiausią amortizuotos masès sukimosi apie skersinę ašị kampą ir mažą neamortizuotos masès pagreitị. 


\section{Automobilio su pusiau aktyvia pakaba eksperimentiniai tyrimai}

Šiame skyriuje pateikta informacija apie atliktus eksperimentinius tyrimus disertacijos tema. Eksperimentiniai tyrimai atlikti Vilniaus Gedimino technikos ir Poznanès technologijos (Lenkija) universitetuose. Tyrimams naudoti automobiliai ir iranga aprašyti 3.1-3.2 poskyriuose.

Skyriaus tematika paskelbtos trys publikacijos (Surblys et al. 2017; Surblys et al. 2018; Surblys et al. 2019).

\subsection{Eksperimentinių tyrimų metodika}

Eksperimentiniai tyrimai atlikti keliais etapais. Pirmojo etapo metu tyrimais siekta išsiaiškinti kelio nelygumų nustatymo metodikos tikslumą. Šių tyrimų metu naudoti trys lazeriniai atstumo jutikliai, o bandymai atlikti automobiliu „MercedesBenz E350“. Antrojo etapo tyrimai skirti išsiaiškinti optimalią lazerinio jutiklio montavimo vietą. Tyrimai atlikti automobiliu ,Audi A6“. Trečiojo etapo metu tyrimai atlikti siekiant validuoti sukurtą pusès automobilio matematinị modelị. Tam atlikti eksperimentiniai bandymai automobiliu „Opel Astra“. Ketvirtojo etapo tyrimai skirti kompensavimo algoritmui patikrinti. Šie tyrimai reikalavo papildomos 
ịrangos, nes realiu laiku reikejjo atlikti skaičiavimus ir gauti pakoreguotą lazerinio jutiklio signalą. Tam pasirinktas Poznanès technologijos universiteto turimas automobilis „Opel Astra“. Automobilis su sumontuotu lazeriniu atstumo jutikliu ir pagrindiniais matmenimis pateiktas 3.1 paveiksle. Automobilis paruoštas vietos mokslininkų ir turi integruotus jutiklius bei $d$ Space gamintojo HIL įrenginị. Išsami informacija apie bandymuose naudotus automobilius pateikta 3.1. lentelèje.

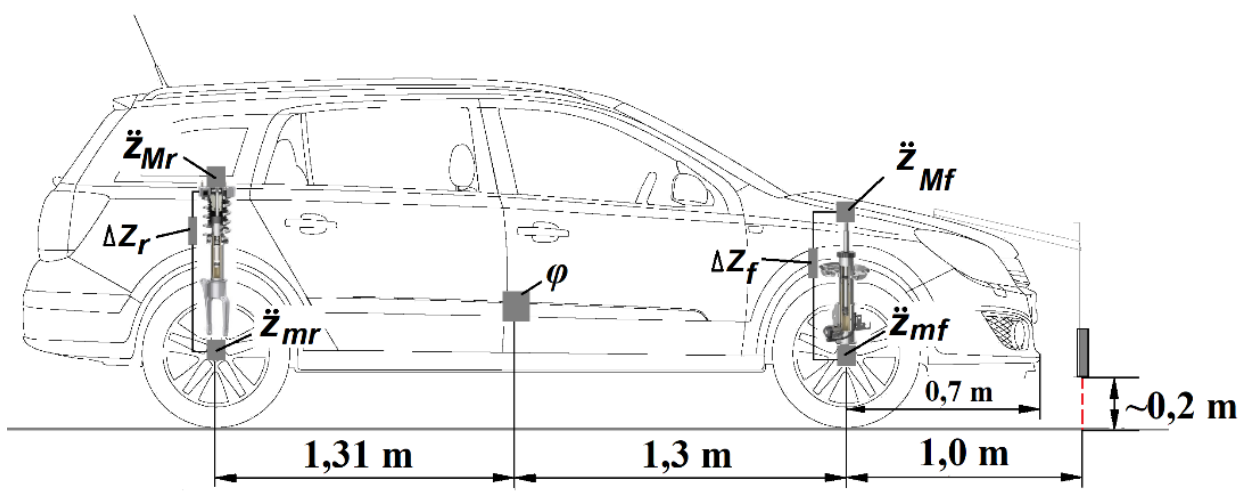

3.1 pav. „Opel Astra“ automobilis su sumontuotu lazeriniu atstumo jutikliu, jo pagrindiniai matmenys ir kita įranga

Fig. 3.1. Opel Astra car with laser height sensor, main dimensions and other equipment

3.1 lentelè. Tyrimuose naudotų automobilių techninès charakteristikos

Table 3.1. Technical specifications of vehicles used in experiments

\begin{tabular}{|l|c|c|c|}
\hline \multirow{2}{*}{ Parametras } & \multicolumn{2}{|c|}{$\begin{array}{c}\text { Poznanès } \\
\text { Tyrimų vieta } \\
\text { technologijos } \\
\text { universitetas } \\
\text { (Lenkija) }\end{array}$} & \multicolumn{2}{|c|}{$\begin{array}{c}\text { Vilniaus Gedimino } \\
\text { technikos universitetas }\end{array}$} \\
\hline \multicolumn{1}{|c|}{ Opel Astra } & Audi A6 & MB E350 \\
\cline { 2 - 4 } & 2 & 3 & 4 \\
\hline Modelio gamybos metai & 2006 & 2006 & 2014 \\
\hline $\begin{array}{l}\text { Variklio darbinis tūis, } \\
\mathrm{cm}^{3}\end{array}$ & 1300 & 2000 & 3500 \\
\hline
\end{tabular}


3.1 lentelès pabaiga

\begin{tabular}{|c|c|c|c|}
\hline 1 & 2 & 3 & 4 \\
\hline Variklio galia, $\mathrm{kW}$ & 66 & 103 & 125 \\
\hline $\begin{array}{l}\text { Variklio sukimo } \\
\text { momentas, } \mathrm{N} \cdot \mathrm{m}\end{array}$ & 200 & 320 & 400 \\
\hline Varančioji ašis & priekinè & priekinè & galinè \\
\hline $\begin{array}{l}\text { Priekinès / galinės } \\
\text { pakabos tipas }\end{array}$ & $\begin{array}{l}\text { „McPherson“/ } \\
\text { daugiasvirtė }\end{array}$ & $\begin{array}{l}\text { „McPherson“ / } \\
\text { daugiasvirté }\end{array}$ & $\begin{array}{l}\text { „McPherson“/ } \\
\text { daugiasvirte }\end{array}$ \\
\hline $\begin{array}{l}\text { Amortizatoriai: tipas, } \\
\text { gamintojas, modelis }\end{array}$ & $\begin{array}{l}\text { Pusiau aktyvūs su ne- } \\
\text { pertraukiamu slopi- } \\
\text { nimo valdymu (angl. } \\
\text { Continuous Damping } \\
\text { Control), ZF Sachs } \\
\text { CDC }\end{array}$ & $\begin{array}{l}\text { Pasyvi pa- } \\
\text { kaba, ZF } \\
\text { Sachs }\end{array}$ & Pasyvi pakaba \\
\hline Bendroji masé, kg & 1348 & 1585 & 1605 \\
\hline $\begin{array}{l}\text { Masės inercijos momen- } \\
\text { tas sukimui apie skersinę } \\
\text { ašị, } \mathrm{kg} \cdot \mathrm{m}^{2}\end{array}$ & 1897,5 & 2816,2 & 2797,9 \\
\hline Ratų bazè, m & 2,61 & 2,84 & 2,87 \\
\hline $\begin{array}{l}\text { Ilgis, m / plotis, m / } \\
\text { aukštis, m }\end{array}$ & $4,25 / 1,75 / 1,46$ & $\begin{array}{l}4,93 / 1,86 / \\
1,46\end{array}$ & $\begin{array}{l}4,88 / 1,85 / \\
1,47\end{array}$ \\
\hline Priekinė iškyša, m & 0,7 & 0,96 & 0,82 \\
\hline $\begin{array}{l}\text { Atstumas nuo svorio } \\
\text { centro iki priekinès ašies, } \\
\mathrm{m}\end{array}$ & 1,3 & 1,42 & 1,43 \\
\hline $\begin{array}{l}\text { Priekinè / galinė tarpvèžè, } \\
\mathrm{m}\end{array}$ & $1,52 / 1,52$ & $1,61 / 1,61$ & $1,56 / 1,56$ \\
\hline $\begin{array}{l}\text { Padangos: tipas, matme- } \\
\text { nys, gamintojas, modelis, } \\
\text { pagaminimo data, protek- } \\
\text { toriaus rašto gylis }\end{array}$ & $\begin{array}{l}\text { vasarinès, } \\
205 / 55 \mathrm{R} 16, \\
\text { Fulda, } 2008 \mathrm{~m} . \\
3 \text { savaite், } 5 \mathrm{~mm}\end{array}$ & $\begin{array}{l}\text { žieminès, } \\
\text { 205/60 R16, } \\
\text { Gislaved EF-5, } \\
2016 \mathrm{~m} .28 \mathrm{sa}- \\
\text { vaite, } 7 \mathrm{~mm}\end{array}$ & $\begin{array}{l}\text { Žieminės, } \\
245 / 45 \text { R17, } \\
\text { Michelin Pilot } \\
\text { Alpin, } 2013 \mathrm{~m} . \\
33 \text { savaité, } \\
7 \mathrm{~mm}\end{array}$ \\
\hline
\end{tabular}

3.1 paveiksle automobilio „Opel Astra“ centre pažymètas svorio centre sumontuotas giroskopas, kuris matuoja sukimo apie skersinę aši kampinį greitị. Ant priekinio ir galinių ratų sumontuotas pagreičio jutiklis, o ant automobilio kẻbulo 
priekinès ir galinės ašių vietose pažymèti pagreičio jutikliai, matuojantys amortizuotos masès vertikalius pagreičius. Priekinejje ir galinèje pakabose sumontuoti pakabos eigos jutikliai. Automobilyje sumontuoti pusiau aktyvūs su nepertraukiamu slopinimo valdymu amortizatoriai. Standartiškai amortizatoriai veikia „Skyhook“ valdymo principu, tačiau tyrimams skirtame automobilyje amortizatoriaus valdymo vožtuvai sujungti su HIL ịrenginiu. Amortizatorius valdyti galima rankiniu būdu arba automatiniu - pagal Matlab/Simulink programiniu paketu parašytą algoritmą. Naudota sistema turi 4 išèjimo kanalus, kuriais galima valdyti 4 automobilio amortizatorius, atsižvelgiant ị skirtingas sąlygas, pvz., sistema, pastebejjusi kliūtị, pagal algoritmą parenka tinkamą slopinimą priekiniams amortizatoriams ir su uždelsimu siunčia valdymo signalą ị galinius amortizatorius.

\subsection{Automobilio dinaminių parametrų matavimo iranga}

Tyrimų metu VGTU ir PTU naudota skirtinga ịranga parametrams matuoti. Visų bandymų metu pasirinkti Kistler Group lazeriniai atstumo jutikliai Corrsys-Datron HF-500C (3.2 pav. 1 numeris). Amortizuotos ir neamortizuotos masès pagreičiui matuoti naudoti Analog Devices ADXL327 (PTU) jutikliai, sukimui apie skersinę ašį matuoti - Bosch YRS3 (PTU) ir Corrsys-Datron TANS-3 (VGTU) jutikliai. Automobilio judèjimo greičiui nustatyti naudotos skirtingos sistemos: PTU - Garmin GPS 5 Hz, o VGTU - Correvit S-350 Aqua. Pakabos eiga matuota Kistler RV-4 (VGTU) ir Kübler A50 (PTU) mechaniniais jutikliais. Visų jutiklių pagrindiniai techniniai parametrai pateikti 3.2 lentelèje, o išsamios specifikacijos - B priede.

3.2 lentelè. Tyrimuose naudotos įrangos techniniai parametrai

Table 3.2 Technical specifications of measuring equipment in eksperimental tests

\begin{tabular}{|c|c|c|c|c|c|c|c|c|}
\hline \multirow{2}{*}{$\begin{array}{c}\text { Matuoja- } \\
\text { mas para- } \\
\text { metras }\end{array}$} & $\begin{array}{c}\text { Gamin- } \\
\text { tojas ir } \\
\text { modelis }\end{array}$ & $\begin{array}{c}\text { Mata- } \\
\text { vimo } \\
\text { tikslu- } \\
\text { mas }\end{array}$ & $\begin{array}{c}\text { Vei- } \\
\text { kimo } \\
\text { princi- } \\
\text { pas }\end{array}$ & $\begin{array}{c}\text { Mata- } \\
\text { vimo } \\
\text { ribos }\end{array}$ & $\begin{array}{c}\text { Gaminto- } \\
\text { jas ir mo- } \\
\text { delis }\end{array}$ & $\begin{array}{c}\text { Mata- } \\
\text { vimo } \\
\text { tikslu- } \\
\text { mas }\end{array}$ & $\begin{array}{c}\text { Vei- } \\
\text { kimo } \\
\text { princi- } \\
\text { pas }\end{array}$ & $\begin{array}{c}\text { Mata- } \\
\text { vimo } \\
\text { ribos }\end{array}$ \\
\hline 1 & 2 & 3 & 4 & 5 & 6 & 7 & 8 & 9 \\
\hline $\begin{array}{l}\text { Pagrei- } \\
\text { čiai, } \\
\ddot{z}_{M}, \ddot{z}_{m}\end{array}$ & \multicolumn{3}{|c}{ nenaudota } & $\begin{array}{l}\text { Analog } \\
\text { Device } \\
\text { ADXL327 }\end{array}$ & $\pm 0,2 \%$ & $\begin{array}{l}\text { Pjezoe- } \\
\text { lektri- } \\
\text { nis }\end{array}$ & $\pm 2,5 g$ \\
\hline
\end{tabular}


3.2 lentelès pabaiga

\begin{tabular}{|c|c|c|c|c|c|c|c|c|}
\hline 1 & 2 & 3 & 4 & 5 & 6 & 7 & 8 & 9 \\
\hline $\begin{array}{l}\text { Sukimas } \\
\text { apie } \\
\text { skersinę } \\
\text { ašit, } \varphi\end{array}$ & $\begin{array}{l}\text { Corr- } \\
\text { sys-Dat- } \\
\text { ron } \\
\text { TANS-3 }\end{array}$ & ${ }_{ \pm 0,1} \%$ & IMU & $\pm 150 \% / \mathrm{s}$ & $\begin{array}{l}\text { Bosch } \\
\text { YRS3 }\end{array}$ & $=0,1 \% / \mathrm{s}$ & IMU & $\pm 160 \% / \mathrm{s}$ \\
\hline $\begin{array}{l}\text { Greitis, } \\
v_{x}\end{array}$ & $\begin{array}{l}\text { Correvit } \\
S-350 \\
\text { Аqua }\end{array}$ & $\pm 0,2 \%$ & Optinis & $\begin{array}{l}0,5-250 \\
\mathrm{~km} / \mathrm{h}\end{array}$ & $\begin{array}{l}\text { Garmin } \\
\text { GPS }\end{array}$ & $=0,2 \%$ & GPS & $\begin{array}{l}0,5-250 \\
\mathrm{~km} / \mathrm{h}\end{array}$ \\
\hline $\begin{array}{l}\text { Pakabos } \\
\text { eiga, } \Delta z\end{array}$ & $\begin{array}{l}\text { Kistler } \\
R V-4\end{array}$ & $\pm 1 \mathrm{~mm}$ & $\begin{array}{l}\text { Mecha- } \\
\text { ninis }\end{array}$ & $200 \mathrm{~mm}$ & $\begin{array}{l}\text { Kübler } \\
\text { A50 }\end{array}$ & $\pm 0,1 \%$ & $\begin{array}{l}\text { Mecha- } \\
\text { ninis }\end{array}$ & $250 \mathrm{~mm}$ \\
\hline $\begin{array}{l}\text { Atstu- } \\
\text { mas iki } \\
\text { pavir- } \\
\text { šiaus, } z_{l}\end{array}$ & $\begin{array}{l}\text { Corr- } \\
\text { sys-Dat- } \\
\text { ron HF- } \\
500 \mathrm{C}\end{array}$ & $\pm 0,2 \%$ & $\begin{array}{l}\text { Lazeri- } \\
\text { nis }\end{array}$ & $\begin{array}{l}125- \\
625 \mathrm{~mm}\end{array}$ & $\begin{array}{l}\text { Corrsys- } \\
\text { Datron } \\
\text { HF-500C }\end{array}$ & $\pm 0,2 \%$ & $\begin{array}{l}\text { Lazeri- } \\
\text { nis }\end{array}$ & $\begin{array}{l}125- \\
625 \mathrm{~mm}\end{array}$ \\
\hline
\end{tabular}

Bandymų metu duomenys rinkti dviem ịrenginiais: Corrsys-Datron DAS-3 (VGTU) (3.2 pav. 2 numeris) ir AutoBox dSpace (PTU) (3.2 pav. 3 numeris). Duomenys įrašyti $500 \mathrm{~Hz}$ dažniu, véliau apdoroti programa Matlab. AutoBox ịrenginys buvo taip pat naudojamas kaip realiu laiku veikiantis kompiuteris pagal sukurtą Matlab/Simulink modeli.

Lazeriniai atstumo jutikliai sparčiai populiarejja industrijoje. Taip pat naudojami automobilių pramonèje integruojant ị naujausias technologijas. Jų matavimo tikslumas ir greitis yra dideli bei nuolat gerinamos charakteristikos. Eksperimentiniams tyrimams pasirinktas Corrsys-Datron gamintojo HF-500C jutiklis (3.3 pav.), skirtas išmatuoti atstumą bekontakčiu būdu. Matavimai gali būti atliekami statiškai ir dinamiškai. 
a)

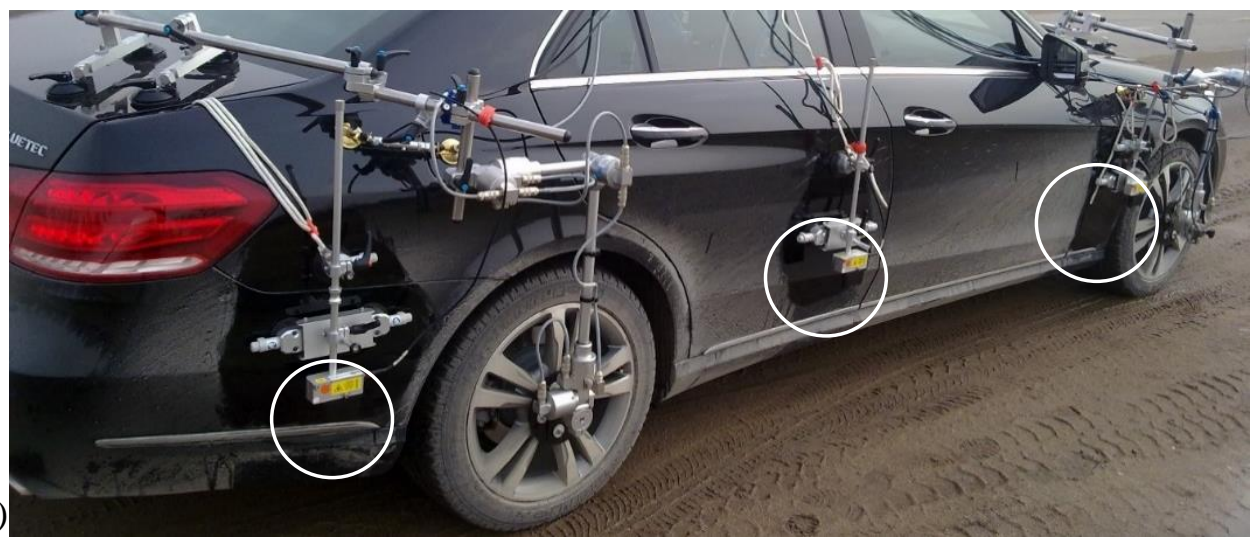

b)
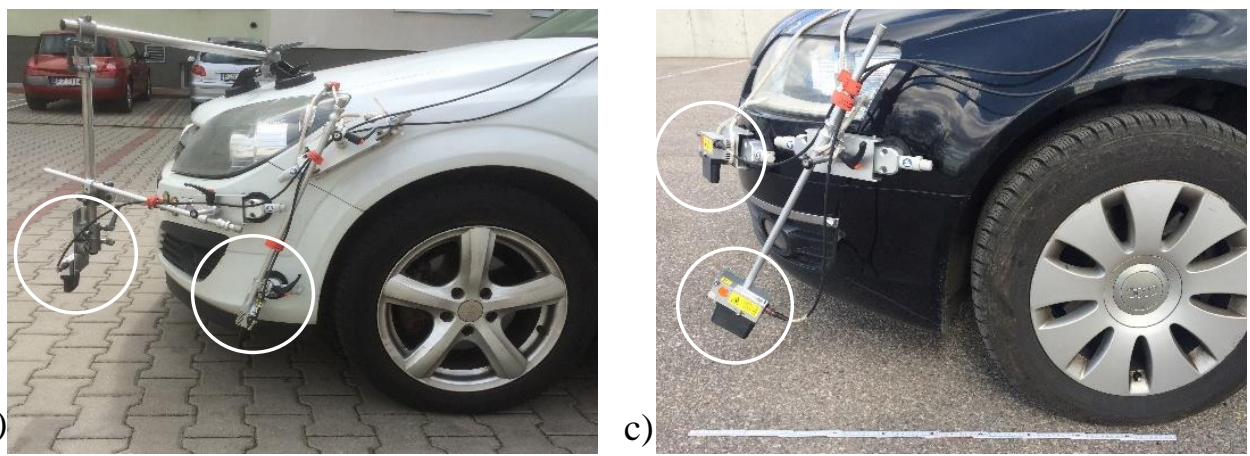

d)
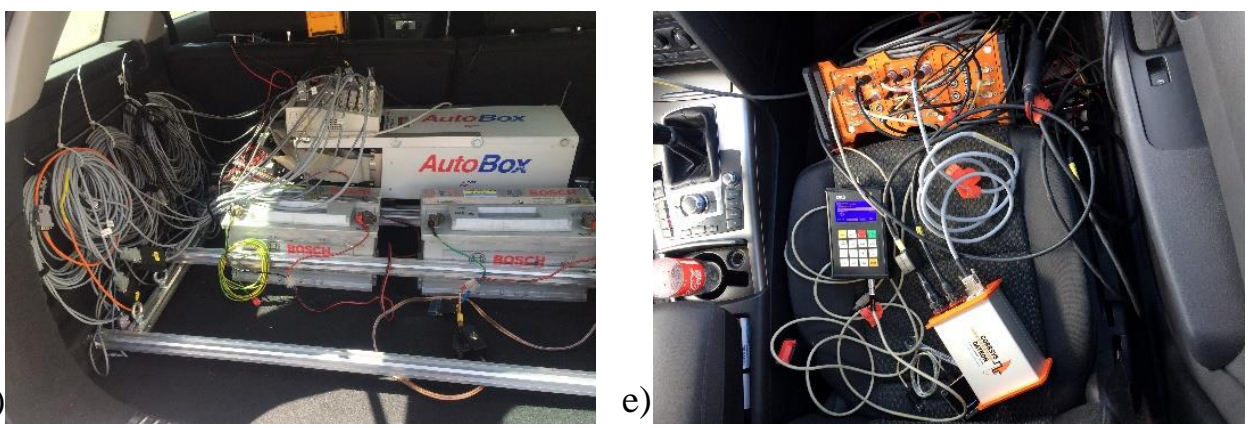

3.2 pav. Tyrimų metu naudota įranga: a) automobilis „Mercedes-Benz E350“;

b) automobilis „Opel Astra“; c) automobilis „Audi A6“ su pažymètais lazeriniais jutikliais Corrsys-Datron HF-500C; d) realiu laiku atliekamų skaičiavimų įrenginys AutoBox dSpace; e) duomenų surinkimo įrenginys Corrsys-Datron DAS-3

Fig. 3.2. Measuring equipment during experimental tests: a) a car Mercedes-Benz E350; b) a car Opel Astra; c) a car Audi A6 with marked laser height sensors Corrsys-Datron HF-500C; d) real time target device AutoBox dSpace; e) data collection device Corrsys-Datron DAS-3; 

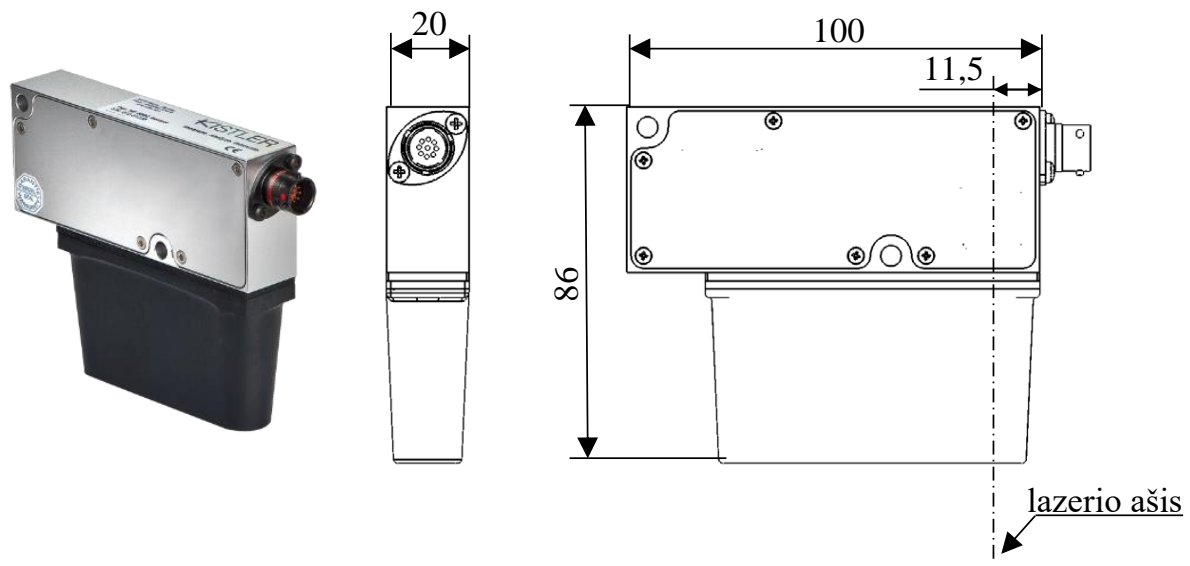

3.3 pav. Lazerinis atstumo jutiklis HF-500C ir jutiklio pagrindiniai matmenys Fig. 3.3. Laser height sensor HF-500C and main sensor dimensions

Jutiklis naudoja $660 \mathrm{~nm}$ bangos ilgio lazerị, kuris siunčiamas ị kelio paviršių. Matuojamas paviršius neapibrěžiamas, koks turètų būti, tačiau turi atspindèti lazerio signalą. Nuo matuojamo paviršiaus priklauso matavimo greitis. Jei paviršius labai gerai atspindi šviesą, matavimo greitis gali pasiekti $8000 \mathrm{~Hz}$ dažnị. Itaiso elektrinė galia yra 1,5 W, kai nominali įtampa $12 \mathrm{~V}$. Mažos elektros energijos sąnaudos leidžia naudoti jutiklius ne tik vidaus degimo variklị turinčiuose automobiliuose, bet hibridiniuose ir elektriniuose.

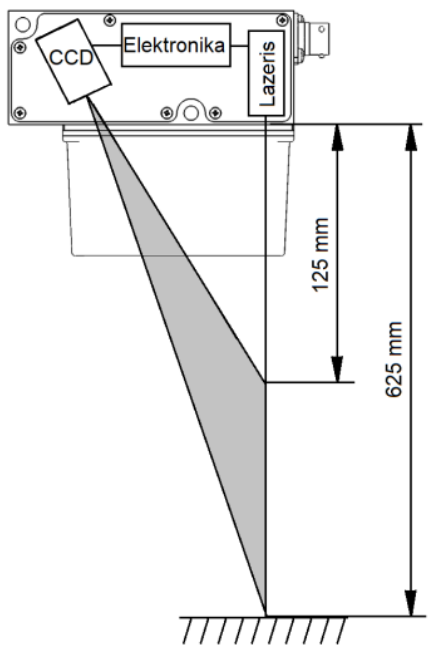

3.4 pav. Lazerinio atstumo jutiklio veikimo ribos

Fig. 3.4. Laser height sensor operating limits 
3.4 paveiksle pavaizduota principinè jutiklio schema. Eksperimentams pasirinkto jutiklio matuojamas atstumas - nuo $125 \mathrm{~mm}$ iki $625 \mathrm{~mm}$. Šis atstumas priklauso nuo jutiklio naudojamos CCD matricos. Matuojamas atstumas yra pakankamas tvirtinant jutikli lengvojo automobilio priekyje ir matuojant atstumą iki kelio paviršiaus.

\subsection{Eksperimentinių duomenų apdorojimas}

Pagreičių jutikliai, fiksuodami parametrus, užfiksuoja papildomą nepageidaujamą reikšmę - triukšmą. Norint ịvertinti eksperimentinių bandymų amortizuotos ir neamortizuotos masės poslinkị, reikia vertikalaus pagreičio reikšmę integruoti. Integravimas bus netikslus, jei gauti bandymų rezultatai nebus filtruoti.

Filtracija ir integracija realiu laiku buvo atlikta naudojant perdavimo funkciją su žemo dažnio filtro charakteristikomis (Savaresi et al. 2010, Sohn et al. 2000):

$$
z_{M}(s)=\frac{1}{s+2 \pi f},
$$

čia $s$-Laplaso transformacijos kintamas, $f$ - filtruojamas dažnis, $\mathrm{Hz}$ (pagreičių signalams buvo naudotas $f=1 \mathrm{~Hz}$ dažnis).

$$
z_{M}(t)=\iint_{t} \ddot{z}_{M}(t) 2 d t,
$$

čia $z_{M}, \ddot{z}_{M}$-amortizuotos masès poslinkis ir pagreitis svorio centro vietoje.

Vieno iš bandymų filtravimo rezultatai pateikti 3.5 paveiksle. Paveiksle pavaizduotas vertikalaus pagreičio jutiklio signalas svorio centro taško vietoje - filtravimas ir integravimas iš pagreičio ị greiti (3.5 pav., a) ir greičio - poslinkio (3.5 pav., b). Iš grafikų matyti, kad filtravimas padeda išvengti signalo žemèjimo integravimo metu.

Kompensavimo algoritme realiu laiku vertikalių pagreičių reikšmes reikejjo integruoti du kartus (gaunamas vertikalus poslinkis), o sukimosi apie skersinę aši kampini greiti - vieną kartą (gaunamas sukimosi apie skersinę ašį kampas). Tam papildomi filtravimo ir integravimo blokai buvo integruoti $i$ kompensavimo algoritmą, o modelis įvestas realaus veikimo kompiuteryje $d$ Space, kuris atliko numatytas funkcijas. 


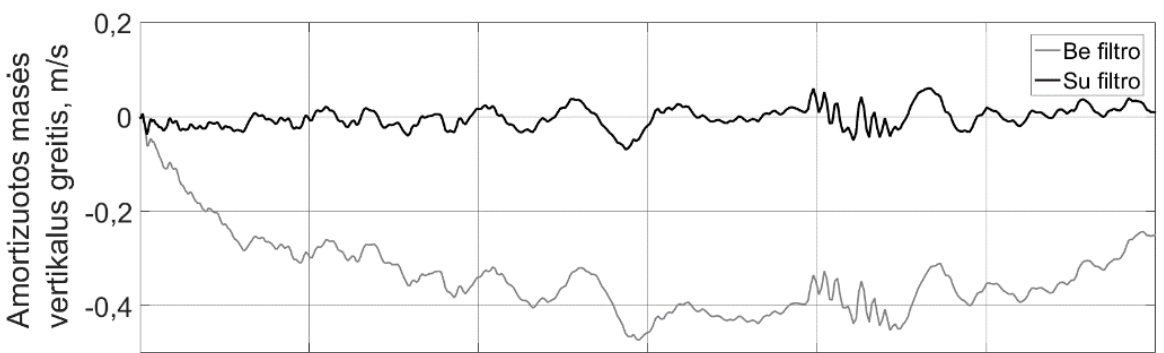

a)

b)

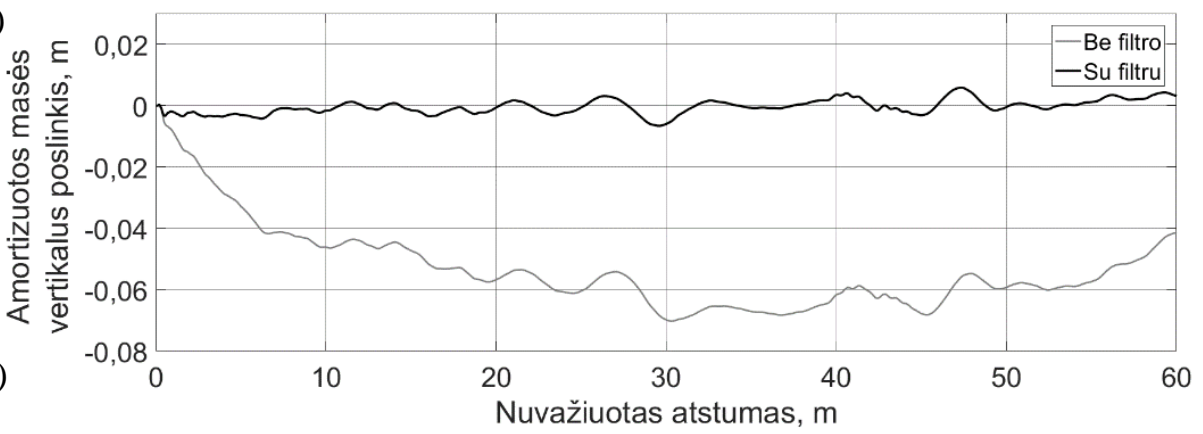

3.5 pav. Signalų filtravimas ir integravimas: a) pagreitis - greitis;

b) greitis - poslinkis

Fig. 3.5. Signal filtering and integration: a) acceleration - velocity;

b) velocity - displacement

\subsection{Kelio nelygumų nustatymo metodų eksperimentiniai tyrimai}

Eksperimentiniams tyrimams pasirinktos dvi sauso asfalto $150 \mathrm{~m}$ ilgio kelio atkarpos, jų paviršių profiliai pateikti 3.6 paveiksle. S1 dangos didžiausias paviršiaus nuokrypis yra 4,8 mm, o S2 dangos - 11,9 mm (Žuraulis et al. 2014). Kelio paviršius nustatytas naudojant mobilią kelių tyrimų laboratoriją RST 28. Tai ant automobilio „Mercedes-Benz Sprinter“ sumontuota ịranga, galinti tiksliai išmatuoti kelio paviršių. Ši laboratorija yra naudojama įmonès „Transporto kompetencijų agentūra“, kuri tiria Lietuvos kelių būklę.

Atliekant bandymus automobiliu „Mercedes-Benz E350“ su sumontuota ịranga buvo važiuojama pastoviu $80 \mathrm{~km} / \mathrm{h}$ greičiu.

Apdorojant bandymų rezultatus, atlikti skaičiavimai 3 metodais:

- Aprašytu Japonišku metodu.

- Patobulintu Japonišku metodu - naudojant tik $h_{i-1}$ ir $h_{i+1}$ (1.9 pav.) reikšmes ir kompensuojant pakabos poslinkị važiuojant automobiliui. 
- Patobulintu Japonišku metodu - naudojant tik $h_{i-1}$ ir $h_{i+1}$ reikšmes ir kompensuojant kèbulo svyravimą apie skersinę ašį.

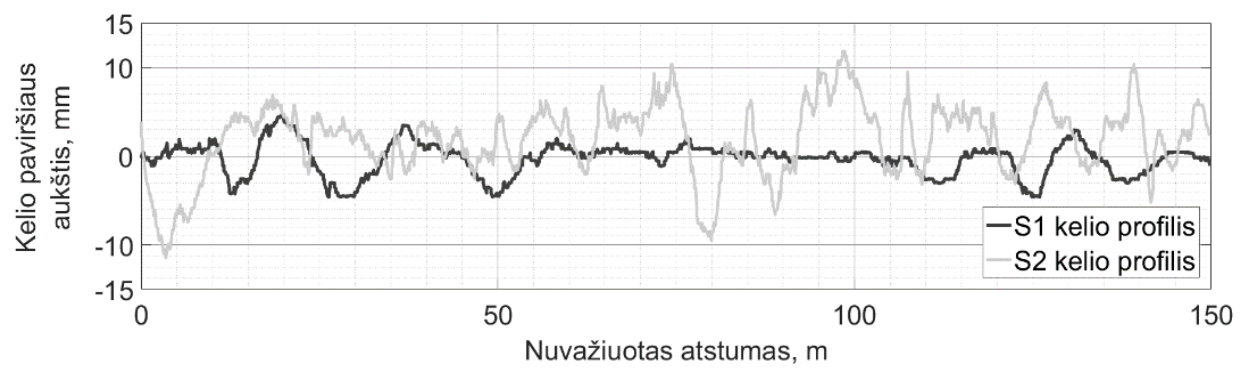

3.6 pav. $\mathrm{S} 1$ ir S2 kelio paviršiaus profiliai

Fig. 3.6. $\mathrm{S} 1$ and $\mathrm{S} 2$ road profile

Apdorojus išmatuotus duomenis pagal 3 metodus, gauti rezultatai pavaizduoti 3.7 ir 3.8 paveiksluose. Kad būtų galima geriau palyginti metodus, vienos kelio atkarpos rezultatai pavaizduoti tame pačiame grafike.

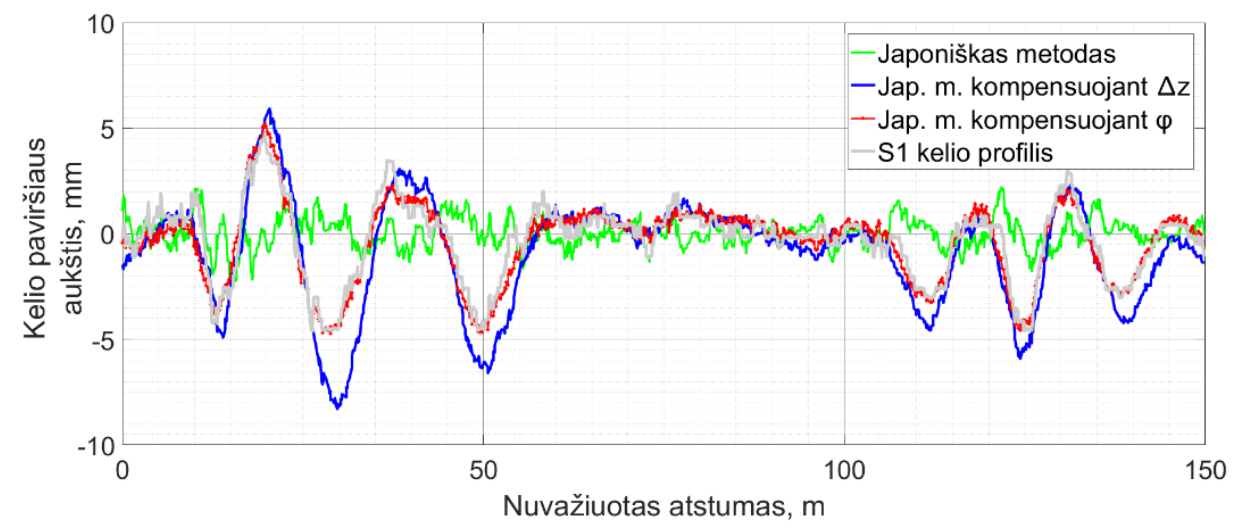

3.7 pav. Trimis metodais nustatytas kelio profilis palygintas su tikruoju S1 atkarpos kelio profiliu

Fig. 3.7. Three methods set out in the road profile compared to the actual road segments $\mathrm{S} 1$ profile

Siekiant dar tiksliau ịvertinti metodus, panaudotas validavimas pagal vidutinę kvadratinę paklaidą. Validavimas atliktas programine įranga Matlab, rezultatai pateikti 3.3 lentelèje. 


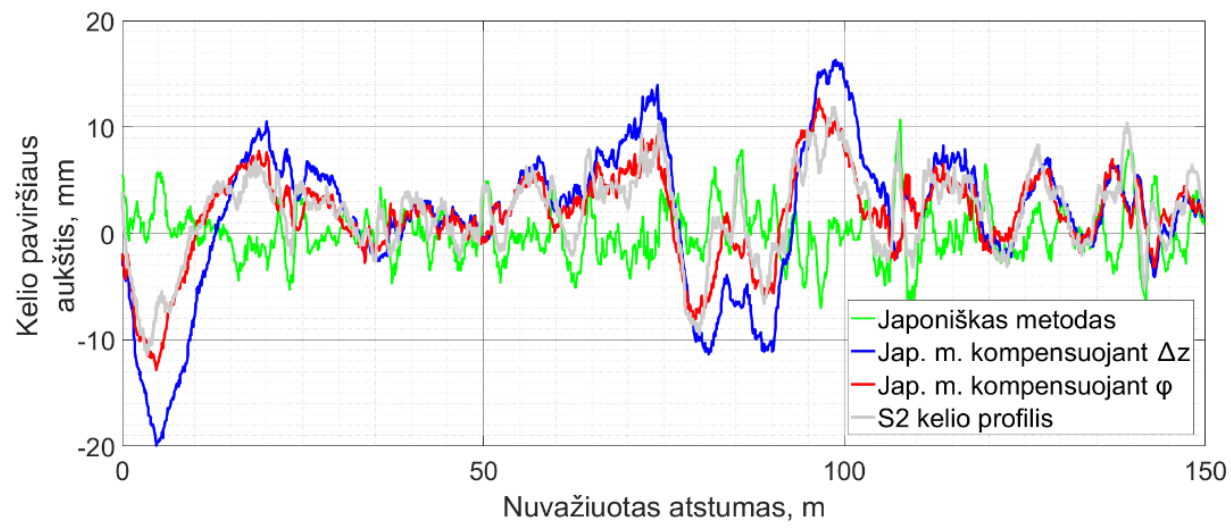

3.8 pav. Trimis metodais nustatytas kelio profilis palygintas su tikruoju S2 atkarpos kelio profiliu

Fig. 3.8. Three methods set out in the road profile compared to the actual road segments S2 profile

Tiksliausiai kelio profili atitinka metodas, kai kompensuojamas sukimas apie skersinę ašį. Šiuo metodu validuojant, vidutinè kvadratinè paklaida yra mažiausia - S1 atkarpoje 0,5728, o S2 atkarpoje 2,4538. Kelio nelygumų nustatymas naudojant Japonišką metodą netiksliai atspindi kelio profili, nes atliekant skaičiavimus pagal 1.21 formulę, šoninių jutiklių $h_{i-1}$ ir $h_{i+1}$ išmatuotų aukščių vidurkis yra atimamas iš vidurinio jutiklio $h_{i}$ aukščio reikšmès.

3.3 lentelè. Kelio nelygumų nustatymo metodų validavimo rezultatai Table 3.3. Results of validation of road roughness detection methods

\begin{tabular}{|l|c|c|}
\hline \multirow{2}{*}{ Matavimo metodas } & \multicolumn{2}{c|}{$\begin{array}{c}\text { Validavimas pagal vidutinę } \\
\text { kvadratinę paklaidą }\end{array}$} \\
\cline { 2 - 3 } & S1 atkarpa & S2 atkarpa \\
\hline Japoniškas metodas & 1,9428 & 4,7157 \\
\hline $\begin{array}{l}\text { Japoniškas metodas kompensavus pakabos } \\
\text { poslinki }\end{array}$ & 1,2804 & 4,2886 \\
\hline $\begin{array}{l}\text { Japoniškas metodas kompensavus sukimą apie } \\
\text { skersinę aši }\end{array}$ & 0,5728 & 2,4538 \\
\hline
\end{tabular}

Patobulintas Japoniškas metodas - naudojant tik $h_{i-1}$ ir $h_{i+1}$ reikšmes ir kompensuojant pakabos poslinkị važiuojančiam automobiliui nèra pakankamai tikslus metodas nustatyti kelio paviršių. Važiuodamas per nelygumus automobilis 
svyruoja, o pakaba slopina kèbulo svyravimus, todèl kompensuojamas pakabos poslinkis, kuris yra didesnis nei tikrasis kelio nelygumas.

\subsection{Pusès sinusoidès formos nelygumas eksperimentiniuose tyrimuose}

Eksperimentiniams tyrimams atlikti pasirinktas pusès sinusoidès formos nelygumas - greičio mažinimo kalnelis. Khot et al. 2017 tyrinejjo MR tipo amortizatorius su pusès sinusoidès formos nelygumu. Pasirinktas aukštis $-0,1 \mathrm{~m}$, o tyrimai atlikti $5,15,25 \mathrm{~km} / \mathrm{h}$ greičiu. Wang et al. 2018 publikacijoje tyrinejjo aktyvią automobilio pakabą. Tyrimams pasirinktas $0,04 \mathrm{~m}$ aukščio greičio mažinimo kalnelis. Agharkakli et al. 2012 atlikdamas pasyvios ir aktyvios pakabos tyrimus naudojo taip pat greičio mažinimo kalnelius, kurių aukščiai $0,05 \mathrm{~m}$ ir $0,1 \mathrm{~m}$.

Patel, Gundaliya 2017 atlikta studija teigia, kad greičio mažinimo kalneliai dažniausiai projektuojami $0,07-0,15 \mathrm{~m}$ aukščio ir skirti sumažinti $40 \mathrm{~km} / \mathrm{h}$ greičiu važiuojančių automobilių greitị.

Atlikus tyrimuose naudojamų kelio nelygumų analizę, nuspręsta bandymuose naudoti $0,05 \mathrm{~m}$ aukščio ir $0,35 \mathrm{~m}$ pločio greičio mažinimo kalnelị (3.9 pav.). Tokių parametrų kalneliai dažni Lietuvos keliuose.

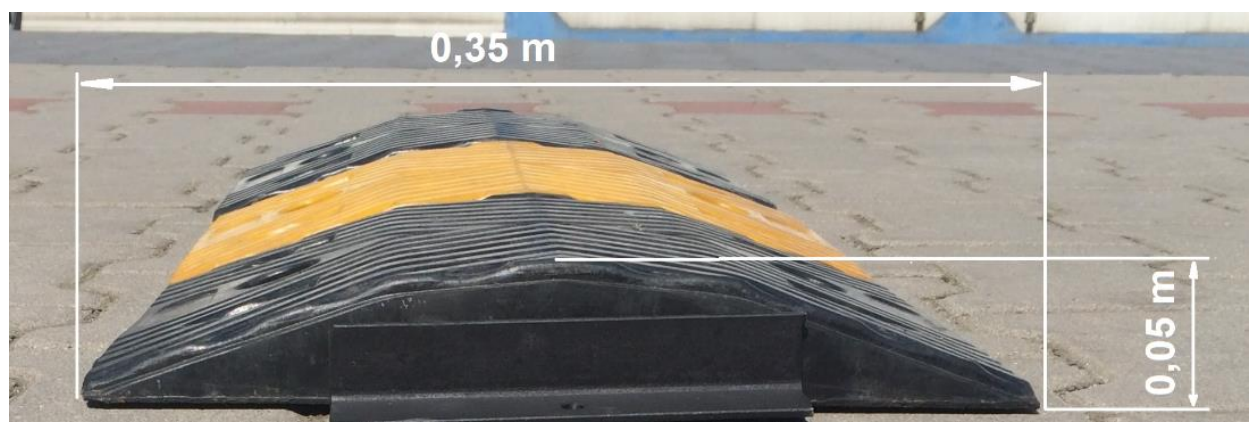

3.9 pav. Pusės sinusoidès formos kelio nelygumas, naudotas eksperimentiniuose bandymuose

Fig. 3.9. Half sinusoidal ramp obstacle during experimental tests

Eksperimentiniuose tyrimuose šių matmenų greičio mažinimo kalnelis buvo naudojamas kilnojamas - norimoje vietoje kalnelis ịtvirtinamas ankeriniais varžtais. Taip kelio nelygumas išliko nejudantis automobiliui važiuojant skirtingu greičiu. 


\subsection{Lazerinio atstumo jutiklio montavimo vietos nustatymo eksperimentiniai tyrimai}

Kelio nelygumo aukščiui ir profiliui nustatyti sistemoje naudojamas lazerinis atstumo matavimo jutiklis. Jutiklio matavimo ribos - 125-625 mm (3.3 lentelè), todèl galima jị montuoti ịvairiose vietose. Kuo didesniu atstumu nuo priekinès automobilio ašies bus sumontuotas jutiklis, tuo daugiau laiko liks amortizatoriaus pasipriešinimo jègoms pakeisti, algoritmas veiks, kai automobilio važiavimo greitis didesnis.

Literatūroje mokslininkai taip pat aprašo tyrimus, kai pasirinktos skirtingos jutiklių montavimo vietos. Straipsnyje (Donahue, Hendrick 2003) jutiklis pritvirtintas virš variklio gaubto su kampu i kelio paviršių. Tokia vieta pasirinkta, nes sistema testuota ant karinio automobilio, o jutiklio veikimo ribos 1,0-5,0 m. Kitame šaltinyje (Çalışkan et al. 2016) lazerinis jutiklis tvirtintas ant priekinio buferio gaubto. Autoriai jutiklị montavo statmenai kelio paviršiui, o prie jutiklio dar pritvirtino akselerometrą, kurio reikia amortizuotos masès virpesiams kompensuoti. Publikacijoje (Ahmed, Svaricek 2014) jutikliai montuoti taip pat prie priekinio buferio gaubto, bet $45^{\circ} \mathrm{kampu}$ ị kelio paviršių. Straipsnio autoriai tyrimams pasirinko „Lidar“ (angl. Light Detection and Ranging) tipo jutiklį.

Pagal jutiklio veikimo ribas buvo pasirinktos dvi jutiklio montavimo vietos ir atlikti eksperimentiniai tyrimai:

- Lazerinis jutiklis nr. 1 buvo sumontuotas $70^{\circ}$ kampu ị kelio paviršiuc (3.9 pav.). Montavimo vieta pasirinkta ant buferio gaubto žemiau kairès pusès priekinio žibinto.

- Lazerinis jutiklis nr. 2 sumontuotas statmenai kelio paviršiui atstumu $1 \mathrm{~m}$ nuo priekinès ašies.

Bandymų metu fiksuotas automobilio važiavimo greitis (3.10 pav.). Naudota iranga pateikta 3.2 poskyryje, 3.2 lentelèje. Automobilis per pusès sinusoidès formos nelygumą (3.9 pav.) važiavo pastoviu $5 \mathrm{~m} / \mathrm{s}$ greičiu.

Nestatmenas lazerinio jutiklio montavimo kampas perskaičiuojamas pagal formulę:

$$
z_{l c}(t)=z_{l}(t) \cdot \cos \alpha,
$$

čia $z_{l c}$ - koreguotas lazerinio jutiklio signalas; $z_{l}$ - išmatuotas lazerinio jutiklio signalas, $\alpha$ - lazerinio jutiklio montavimo kampas iki vertikalios keliui ašies (nau$\operatorname{dotas} 70^{\circ}$ ).

Iš 3.11 paveikslo rezultatų matyti, kad statmenai pritvirtinto jutiklio signalas atspindi nelygumo formą bei aukštị. Jutiklis nr. 1 užfiksavo didesnị nelygumo aukštį $(0,054 \mathrm{~m})$, bet matematiškai perskaičiavus jutiklio signalą gautas jutiklio nr. 2 užfiksuotas aukštis $-0,051 \mathrm{~m}$. 

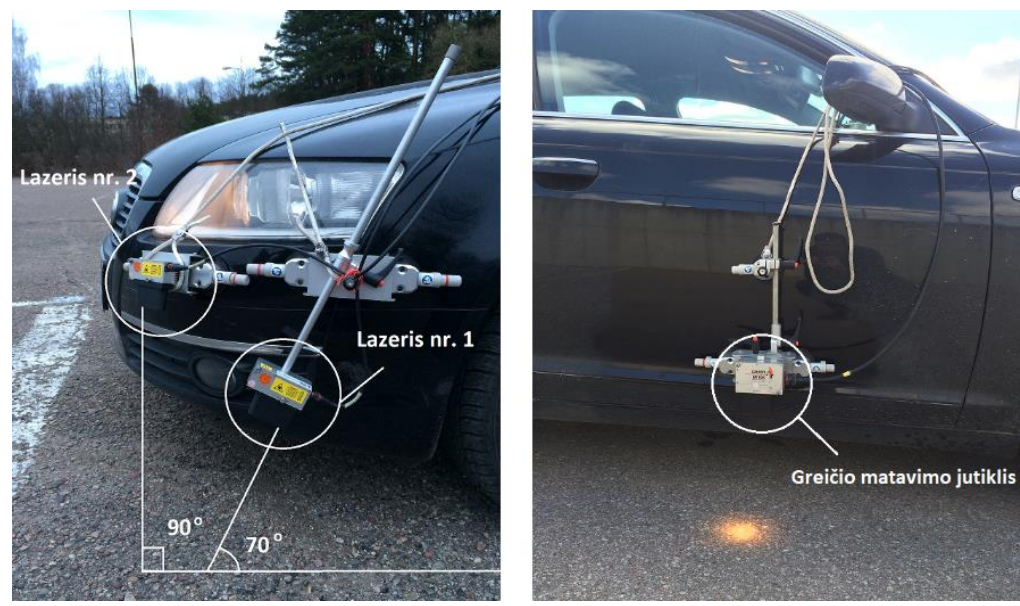

3.10 pav. Matavimo įrangos montavimas ant automobilio „Audi A6“:

Fig. 3.10. Mounting of measuring equipment on Audi A6 vehicle

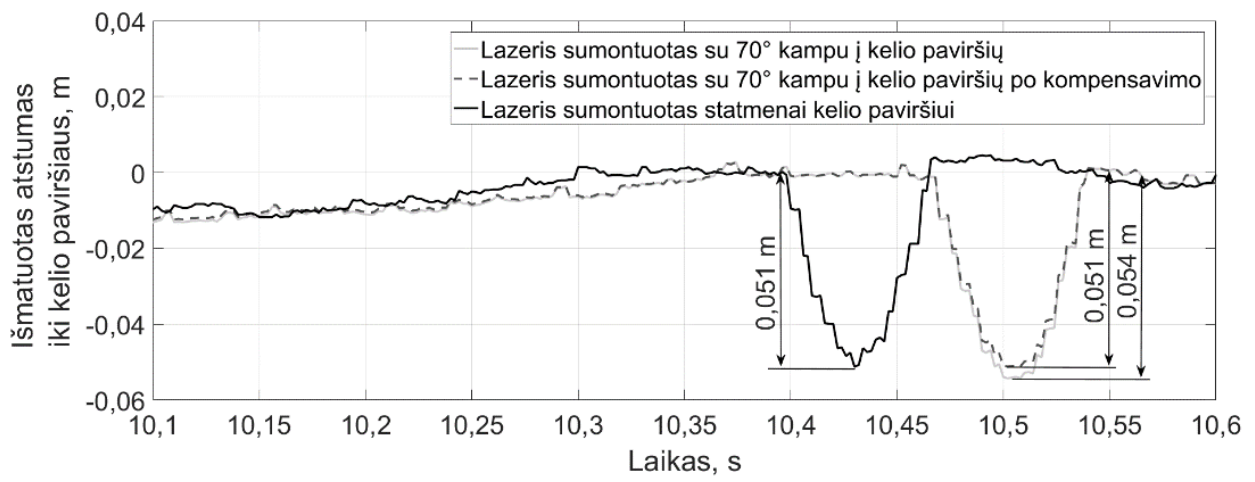

3.11 pav. Lazeriniais atstumo jutikliais išmatuotas kelio nelygumas

Fig. 3.11. Laser sensors measured road irregularity

Atstumo jutiklio matavimo tikslumas yra $\pm 0,2 \%$. Jutiklis matuoja atstumą nuo $1000 \mathrm{~Hz}$ iki $8000 \mathrm{~Hz}$ dažniu. Matavimo dažnis priklauso nuo paviršiaus, ị kuri atsimuša siunčiamas lazerinio jutiklio signalas. Matavimo greičio pakanka, net jei kelio paviršius prastai atspindi lazerio siunčiamas bangas, nes eksperimentinių bandymų metu duomenys fiksuoti $500 \mathrm{~Hz}$ dažniu. 


\subsection{Kompensavimo algoritmo eksperimentinių tyrimų rezultatų analizè}

Eksperimentiniai tyrimai atlikti norint ịvertinti, kaip veikia sukurtas kompensavimo algoritmas realiomis sąlygomis. Algoritmas aprašytas 2.11 poskyryje. Tyrimams pasirinkta $70 \mathrm{~m}$ sauso asfalto kelio atkarpa. Kelio žadinimu pasirinktas pusès sinusoidès formos $(0,05 \mathrm{~m})$ kelio nelygumas (3.9 pav.).

Bandymų metu automobilis judëjo $30 \mathrm{~km} / \mathrm{h}$ pastoviu greičiu. Siekiant tiksliau ịvertinti kompensavimo algoritmą, tyrimai atlikti su skirtingais amortizatorių nustatymais - maksimaliomis ir minimaliomis pasipriešinimo jègomis.

3.12 ir 3.13 paveiksluose pateikti gautų bandymų rezultatai su ir be kompensavimo. Gautos kreivės rodo, kad kompensavimo algoritmas sumažina amortizuotos masès vertikaliuosius svyravimus ir leidžia įvertinti realų kelio profilį. Abiem pakabos sureguliavimo atvejais atlikus kompensaciją lazerinio jutiklio signalas atspindi tikraji kelio nelygumo aukštį. Kai amortizatoriai sureguliuoti minimaliomis pasipriešinimo jègomis, lazerinis jutiklis užfiksavo $0,067 \mathrm{~m}$ dydžio nelygumą, o po kompensavimo nelygumo aukštis atitiko $0,052 \mathrm{~m}$. Kai amortizatoriai nustatyti su maksimalia pasipriešinimo jèga, nelygumo aukštis užfiksuotas $0,035 \mathrm{~m}$, po kompensavimo $-0,052 \mathrm{~m}$. Abiem atvejais nelygumo aukštis po kompensavimo atitiko $96,4 \%$ realų aukštį.

Kreivèse po kompensavimo tebėra papildomų kelio profilio šuolių, kuriuos sunku vertinti, nes bandymo metu kelio paviršius nebuvo idealiai lygus, o automobilio judejjimas nebuvo visiškai pastovus.

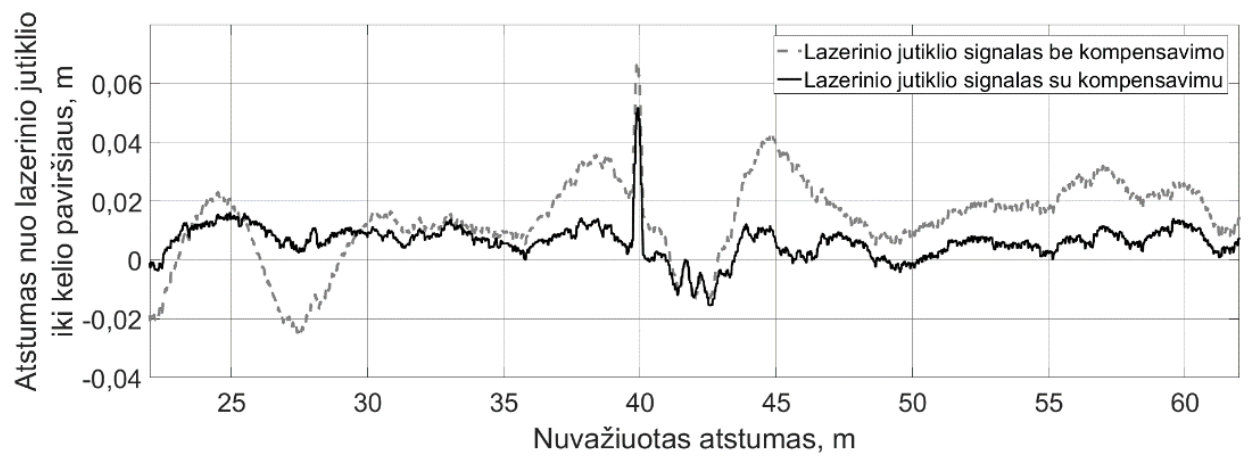

3.12 pav. Kelio profilio ịvertinimas naudojant lazerinị jutiklị, kai pakaba sureguliuota minimaliu slopinimu

Fig. 3.12. The road profile estimation using laser sensor, soft damping case 


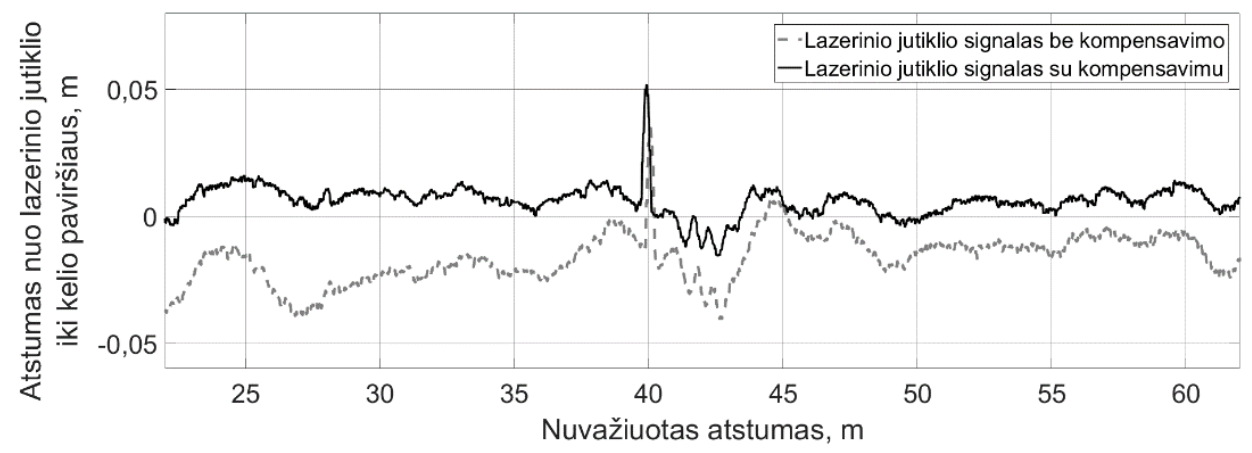

3.13 pav. Kelio profilio ịvertinimas naudojant lazerinị jutiklį, kai pakaba sureguliuota maksimaliu slopinimu

Fig. 3.13. The road profile estimation using laser sensor, stiff damping case

3.13 paveikslo bandymuose, kai amortizatoriai buvo sureguliuoti minimalia pasipriešinimo jèga, matyti didesni amortizuotos masès svyravimai, kai automobilis nuvažiuoja nuo kliūties, tačiau kompensavimo algoritmas atlieka savo funkciją - svyravimus minimalizuoja.

\subsection{Pusiau aktyvios pakabos su nelygumų nustatymu eksperimentinių tyrimų rezultatų analizè}

Išanalizavus svyravimų kompensavimo rezultatus ir žinant realų kelio paviršių, galima taikyti pusiau aktyvios pakabos su kelio nelygumų nustatymu sukurtą valdymo algoritmą. Teoriniais tyrimais patvirtinta, kad tinkamiausias 2.13.1 poskyryje aprašytas Algoritmas 1, kuris veikia pagal iš anksto nustatytą kelio nelygumo aukšti.

Šiame skyriuje aprašoma eksperimentinių - teorinių tyrimų rezultatų analizè. Rezultatai lyginami slopinimo elementus valdant Algoritmu 1, „Skyhook“ valdymo principu su pasyvia pakaba. Realioje sistemoje realiu laiku lazerinio jutiklio signalai apdorojami pagal anksčiau aprašytą kompensavimo algoritmą, o signalas panaudojamas valdymo sistemoms.

3.14 paveiksle pateiktas automobilio kèbulo vertikalus poslinkis. Grafike atsispindi Algoritmo 1 privalumai: automobilis pervažiuodamas per kelio nelygumą neturi poslinkio ị viršų, o tik 0,02 m nesiekiantị poslinkị ị apačią. ,Skyhook“ valdymo principu važiuojančio automobilio amortizuotos masès vertikalaus poslinkio amplitudè nèra didelè $(0,035 \mathrm{~m})$, tačiau svyravimai trunka ilgiau. Automobilio judejjimas su pasyvia pakaba turi daugiausiai trūkumų, nes svyravimų amplitudè didele - viršija $0,04 \mathrm{~m}$ ir svyravimai trunka ilgai. 


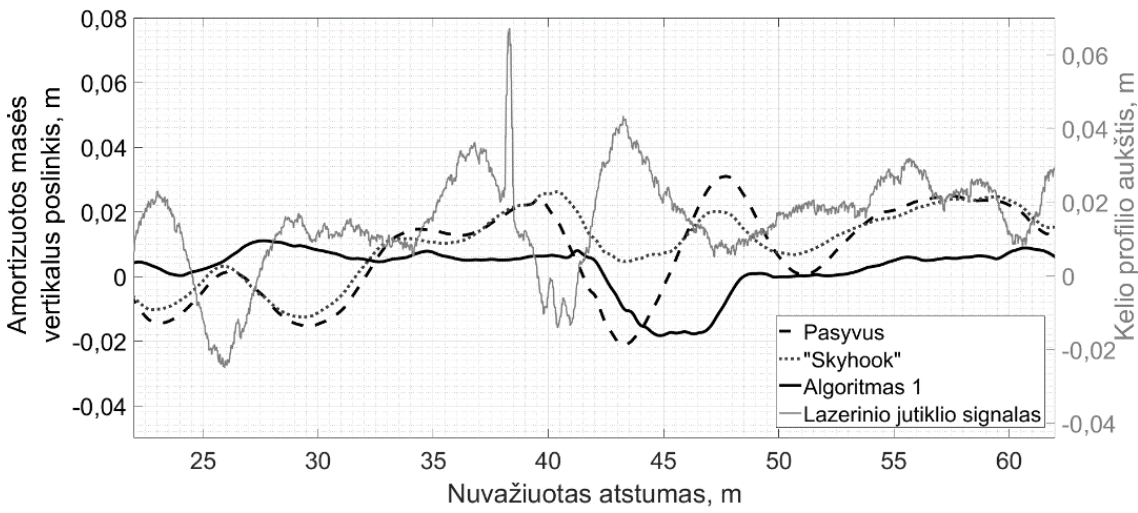

3.14 pav. Amortizuotos masès vertikalus poslinkis, kai pakaba pasyvi, valdomai „Skyhook“ principu ir naujai sukurtu Algoritmo 1 valdymo principu, kai greitis $30 \mathrm{~km} / \mathrm{h}$

Fig. 3.14. Sprung mass vertical displacement with passive, "Skyhook" control and novel algorithm called Algoritmas 1 at $30 \mathrm{~km} / \mathrm{h}$ velocity

Sukimosi apie skersinę aši kampas naudojant Algoritma 1 yra nuo $-0,9^{\circ}$ iki $0,9^{\circ}$ (minusas atspindi automobilio sukimąsi svorio centre pagal laikrodžio rodyklę) pervažiavus per nelygumą (3.15 pav.). Tuo pačiu metu „Skyhook“ yra nuo $-0,9^{\circ}$ iki $1,6^{\circ}$, o pasyvi pakaba $--1,7^{\circ}$ iki $2,5^{\circ}$. Amortizuotos masès sukimas apie skersinę ašį yra svarbus parametras, turintis įtakos važiavimo komfortui (vairuotojas ir keleiviai, važiuojantys automobiliu, nejaučia kẻbulo svyravimų), važiavimo saugumui (maksimaliai užtikrinamas rato su kelio paviršiumi kontaktas pervažiavus nelygumą).

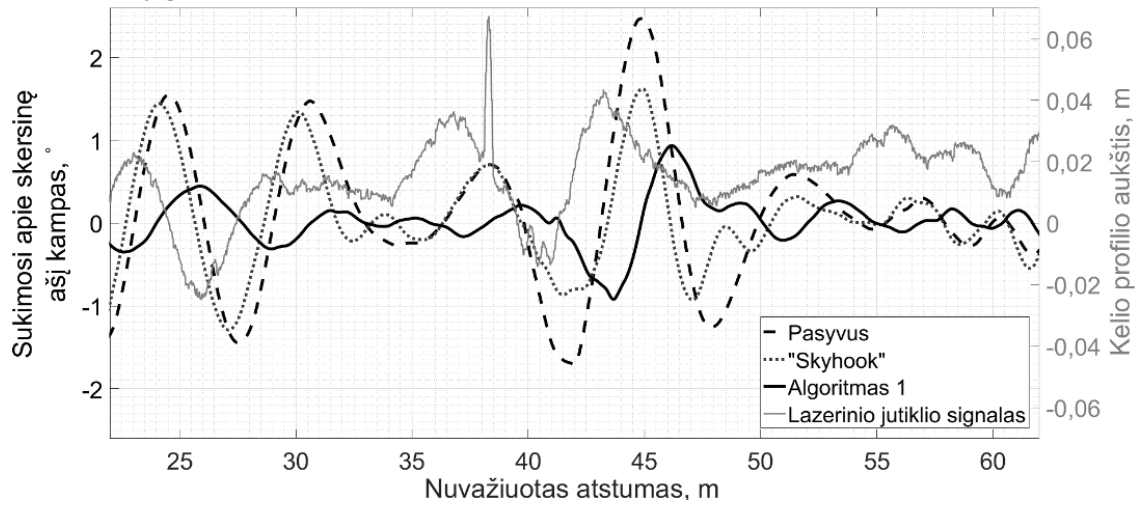

3.15 pav. Sukimasis apie skersinę aši, kai pakaba pasyvia, valdoma „Skyhook“ principu ir naujai sukurtu Algoritmas 1 valdymo principu, greitis $30 \mathrm{~km} / \mathrm{h}$

Fig. 3.15. Pitch with passive, "Skyhook" control and novel algorithm called Algoritmas 1 at $30 \mathrm{~km} / \mathrm{h}$ velocity 
Neamortizuotos masès pagreičio skirtumo tarp skirtingų valdymo principu analizei atlikti pasirinktas grafiškas dažnių spektro vaizdavimas (3.16 pav.). Priekinio ir galinių ratų pagreičių charakteristikos beveik nesiskiria, dažnis -1-16 Hz. Amortizatoriams, veikiantiems „Skyhook“ valdymo principu $3 \mathrm{~Hz}$ dažniu, pastebimas amplitudès padidèjimas, tam turi įtakos ne laiku pakeičiamos pasipriešinimo jègos, nes automobilio ratas gauna vertikalų žadinimą, o pasipriešinimo jègos pakeičiamos po apytiksliai 0,073 s. Ši charakteristika nèra ypač svarbi neamortizuotų masių dinamikai, tačiau svarbi amortizuotos masès dinamikai ir važiavimo komfortui, nes žmogaus vidaus organų savasis dažnis yra 3-9 Hz.
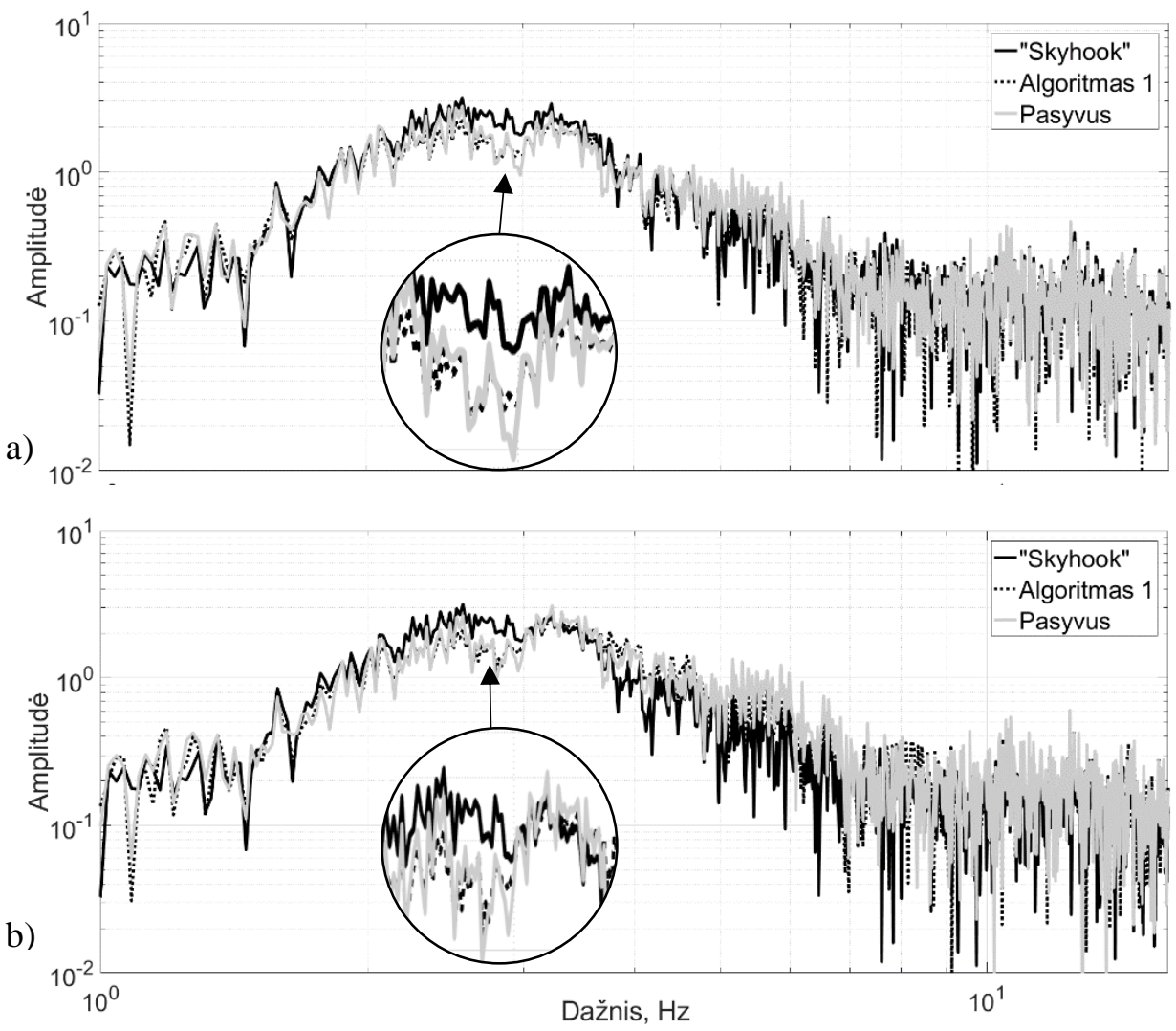

3.16 pav. Neamortizuotų masių pagreičiu dažninių spektras:

a) priekinès ašies; b) galinès ašies

Fig. 3.16. Unsprungs masses accelaration frequency spectrum:

a) front axle; b) rear axle 
Apžvelgus 3.14-3.16 paveikslus matyti, kad automobilis, naudojantis Algoritmo 1 valdymo principą, važiuoja komfortiškiau, palyginti su pasyvia pakaba ir „Skyhook“ valdymo principu, nes matomas mažesnis amortizuotos masès poslinkis ir sukimosi apie skersinę ašį kampas. Eksperimentiniai tyrimai patvirtino, kad laiku pakeičiamos amortizatoriaus pasipriešinimo jègos sumažina automobilio kèbulo svyravimus, kai automobilis važiuoja per sinusoidès formos greičio mažinimo kalnelį.

\subsection{Trečiojo skyriaus išvados}

1. Kelio nelygumams nustatyti plačiai taikomas Japoniškas metodas nėra tinkamas, kai jutikliai montuojami prie standartinio automobilio kẻbulo, nes nėra kompensuojamas amortizuotos masès sukimasis apie skersinę ašị.

2. Pritaikius kèbulo svyravimų apie skersinę aši kompensavimą, gautas tiksliausias kelio paviršiaus nelygumų dydis, kurị validavus pagal tikrajị kelio profilị skirtingo lygumo kelio atkarpose, gautos nuo 1,92 iki 3,39 karto mažesnès vidutinès kvadratinès paklaidos. Pritaikius ne tokị efektyvų pakabos eigos kompensavimą, vidutinès kvadratinès paklaidos mažèja 1,1-1,52 karto.

3. Iš eksperimentinių tyrimų nustatyta, kad tiksliausias matavimas yra tada, kai lazeris pritvirtintas statmenai kelio paviršiui. Jei lazeris tvirtinamas $70^{\circ}$ kampu i kelio paviršių ir atliekamas kampo kompensavimas, galima gauti labai artimus rezultatus tikram kelio profiliui.

4. Eksperimentiniu būdu gauti pagreičių jutiklių duomenys yra triukšmingi, todèl turi būti filtruojami naudojant perdavimo funkciją su žemo $(1 \mathrm{~Hz})$ dažnio filtro charakteristikomis.

5. Sukurto amortizuotos masės svyravimo kompensavimo algoritmo tikslumas, patikrintas eksperimentiniais tyrimais. Nelygumo aukštis po kompensavimo atitiko $96,4 \%$ realaus nelygumo aukščio.

6. Patikrinus eksperimentiniu būdu gautus duomenis su sukurtu valdymo algoritmu, ,Skyhook“ valdymo principu ir pasyvia pakaba, nustatytos algoritmo savybès. Amortizuotos masės poslinkio amplitudè bandymo metu buvo iki $48 \%$ mažesnè nei automobilio su pasyvia pakaba, o svyravimai truko trumpiau, palyginti su „Skyhook“ valdymo principu. Taip pat sukimosi apie skersinę ašį kampas yra mažesnis vidutiniškai 40 \%, palyginti su „Skyhook“ valdymo principu.

7. Neamortizuotos masès vertikalaus pagreičio amplitudè (Algoritmo 1, „Skyhook“, pasyvios pakabos) beveik nesiskiria - siekia 1-16 Hz dažnių. 
Skirtumas pastebimas ties $3 \mathrm{~Hz}$ dažniu, kai naudojant „Skyhook“ valdymo principą matomas amplitudès padidèjimas, tam turi ịtakos ne laiku pakeičiamos pasipriešinimo jègos, nes automobilio ratas gauna vertikalų žadinimą, o pasipriešinimo jègos pakeičiamos po apytiksliai $0,073 \mathrm{~s}$. 


\section{Bendrosios išvados}

1. Sukurtas pusès automobilio su sumontuotu lazeriniu atstumo jutikliu matematinis modelis leidžia tyrinèti nevienodu greičiu per skirtingo aukščio kelio nelygumus važiuojančio automobilio dinamiką. Gaunamą lazerinio jutiklio signalą galima panaudoti sistemų algoritmų tikrinimui bei naujų sistemų kūrimui.

2. Teoriniais tyrimais nustatyta, kad pusiau aktyvios pakabos valdymo principas „Skyhook“ sumažina amortizuotos masès poslinkị važiuojant automobiliui per pusès sinusoidès formos $0,05 \mathrm{~m}$ aukščio greičio mažinimo kalnelį $30 \mathrm{~km} / \mathrm{h}$ greičiu, sukimosi apie skersinę aši kampas mažèja vidutiniškai $0,34^{\circ}$.

3. Eksperimentiniais tyrimais nustatyta, kad racionali lazerinio atstumo jutiklio montavimo vieta yra ant automobilio priekinio buferio gaubto statmenai kelio paviršiui. Lazerinio atstumo jutiklio montavimo atstumas nuo priekinès ašies turi įtakos amortizatorių pasipriešinimo jègų pakeitimo laikui ir maksimaliam automobilio greičiui, nes kelio paviršius matuojamas prieš ratui užvažiuojant ant nelygumo.

4. Pusiau aktyvios pakabos valdymo principai su kelio paviršiaus nelygumų nustatymu prieš ratui užvažiuojant ant jo leidžia sumažinti amortizuotos masès sukimosi apie skersinę aši kampą ir pagerinti neamortizuotos masės dinaminius parametrus. 
5. Atlikus $30 \mathrm{~km} / \mathrm{h}$ greičiu važiuojančio automobilio per pusès sinusoidès formos $0,05 \mathrm{~m}$ aukščio kelio nelygumą eksperimentiniu būdu gautų duomenų rezultatų analizę, nustatyta, kad sukurtas valdymo algoritmas sumažina sukimą apie skersinę aši (nuo $-0,9^{\circ}$ iki $0,9^{\circ}$, kai „Skyhook“ yra nuo $-0,9^{\circ}$ iki $1,6^{\circ}$, o pasyvi pakaba $--1,7^{\circ}$ iki $\left.2,5^{\circ}\right)$; vertikalių svyravimų poslinkị $(0,02 \mathrm{~m}$ mažesnis) ir trukmę; neamortizuotų masių svyravimų amplitudę (mažesnè ties $3 \mathrm{~Hz}$ dažniu).

6. Pusiau aktyvių amortizatorių pasipriešinimo jègų keitimas prieš ratui užvažiuojant ant nelygumo yra naudinga, nes sistema keičia pasipriešinimo jègas dar ratui nepasiekus kliūties. Tokiu atveju automobilio dinamikai neturi įtakos amortizatorių elektroninis ir mechaninis uždelsimai, kurie priklauso nuo konkrečių amortizatorių. 


\section{Literatūra ir šaltiniai}

Abramov, S.; Mannan, S.; Durieux, O. 2009. Semi-Active Suspension System Simulation Using SIMULINK, International Journal of Engineering Systems Modelling and Simulation, 1(2/3), 101-114.

Agharkakli, A.; Sabet, G. S.; Barouz, A. 2012. Simulation and Analysis of Passive and Active Suspension System Using Quarter Car Model for Different Road Profile, International Journal of Engineering Trends and Technology 3(5): 636-644.

Ahmed, M. M.; Svaricek, F. 2013. Preview Control of Semi-active Suspension Based on a Half-car Model Using Fast Fourier Transform, 10th International Multi-Conference on Systems, Signals \& Devices: 1-6. DOI: 10.1109/SSD.2013.6564120

Ahmed, M. M.; Svaricek, F. 2014. Preview Optimal Control of Vehicle Semi-active Suspension Based on Partitioning of Chassis Acceleration and Tire Load Spectra, European Control Conference (ECC): 1669-1674.

Aki, A.; Rojanaarpa, T.; Nakano, K.; Suda, Y.; Takasuka, N.; Isogai, T.; Kawai, T. 2016. Road Surface Recognition Using Laser Radar for Automatic Platooning, IEEE Transaction on intelligent transportation systems 17(10): 2800-2810.

http://dx.doi.org/10.1109/TITS.2016.2528892

Aly, A. A.; Salem, F. A. 2013. Vehicle Suspension Systems Control: A Review, International Journal of Control Automation and Systems 2(2): 46-54. 
Alvarez-Sánchez, E. 2013. A quarter-car suspension system: car body mass estimator and sliding mode control, Procedia Technology 7: 208-214.

http://dx.doi.org/10.1016/j.protcy.2013.04.026

ASTM E1926-08. 2015. Standard practice for computing International Roughness Index of Roads from longitudinal profile measurements, ASTM International, West Conshohocken, PA.

Ata, W. G.; Salem, A. M. 2017. Semi-active control of tracked vehicle suspension incorporating magnetorheological dampers, Vehicle System Dynamics: 1-22.

http://dx.doi.org/10.1080/00423114.2016.1273531

Aubouet, S.; Sename, O.; Talon, B.; Poussot-Vassal, C.; Dugard, L. 2008. Performance analysis and simulation of a new industrial semi-active damper, Proceedings of the 17th World Congress The International Federation of Automatic Control: 4671-4676. DOI:10.3182/20080706-5-KR-1001.2403

Barbosa, R. S. 2011. Vehicle dynamic response due to pavement roughness, Journal of the Brazilian Society of Mechanical Sciences and Engineering 33(3): 302-307.

Bogdevičius, M. 2012. Transporto priemoniu dinamika. Mokomoji knyga. Vilnius: Technika. 206 p.

Bogdevičius, M.; Junevičius, R.; Vansauskas, V. 2012. Transporto priemoniu dinamika. Metodiniai praktinių užsiemimu nurodymai. Vilnius: Technika. 90 p.

Bogdevičius, M.; Prentkovskis, O.; Junevičius, R.; Skrickij, V.; Šukevičius, Š. 2016. Behavior and optimization of pneumatic damping system, Iranian journal of science and technology, transactions of mechanical engineering 40(2): 105-112.

Bottega, W. J. 2006. Enginering vibrations. CRC / Taylor \& Francis. 726 p.

Bouzouraa, M. E.; Kellner, M.; Hofmann, U.; Lutz, R. 2014. Laser scanner based road surface estimation for automotive applications, IEEE SENSORS 2014 Proceedings, Valencia: 2034-2037. http://dx.doi.org/10.1109/ICSENS.2014.6985434

Çalışkan, K.; Henze, R.; Küçükay, F. 2016. Potential of Road Preview for Suspension Control under Transient Road Inputs, International Federation of Automatic Control 49(3): 117-122. DOI: 10.1016/j.ifacol.2016.07.020

Canale, M.; Milanese, M.; Novara, C. 2006. Semi-Active Suspension Control Using "Fast" Model-Predictive Techniques, IEEE Transactions on Control Systems Technology 14(6): 1034-1046.

Carter, A. K. 1998. Transient Motion Control of Passive and Semi-active Damping for Vehicle Suspensions, Master's Thesis, Virginia Polytechnic Institute and State University, $106 \mathrm{p}$.

Celko, J.; Decky M.; Kovas M. 2009. An analysis of vehicle - road surface interaction for classification of IRI in the of Slovak PMS, Maintenance and Reliability 1: 15-21.

Chen, W.; Xiao, H.; Wang, Q.; Zhao, L.; Zhu, M. 2016. Integrated vehicle dynamics and control. Wiley, $359 \mathrm{p}$. 
Choi, S. B.; Han, Y. M. 2013. Magnetorheological fluid technology: applications in vehicle systems. CRC Press, $322 \mathrm{p}$.

Choi, S. B.; Suh, M. S.; Park, D. W.; Shin, M. J. 2001. Neuro-Fuzzy Control of a Tracked Vehicle Featuring Semi-Active Electro-Rheological Suspension Units, Vehicle System Dynamics 35(3): 141-162.

Crosby, M. J.; Karnopp, D. C. 1973. The active damper - a new concept for shock and vibration control, Shock Vib Bull 43: 119-133.

Dąbrowski, K.; Ślaski, G. 2016. Method and algorithm of automatic estimation of road surface type for variable damping control, Scientific Conference on Automotive Vehicles and Combustion Engine: 1-10. http://dx.doi.org/10.1088/1757-899X/148/1/012028

Donahue, M. D.; Hedrick, J. K. 2003. Implementation of an Active Suspension, Preview Controller for Improved Ride Comfort, Nonlinear and Hybrid Systems in Automotive Control, 1-23.

Dutta, D. 2017. Semi-active suspension system of car model design: a comparative study, Australian Journal of Mechanical Engineering, DOI: 10.1080/14484846.2017.1372029

Emam, A. S.; Ghany, M. 2012. Enhancement of Ride Quality of Quarter Vehicle Model by Using Mixed $\mathrm{H}_{2} / \mathrm{H}_{\infty}$ with Pole-Placement, Engineering 4: 126-132. http://dx.doi.org/10.4236/eng.2012.42016

Fateh, M. M.; Alavi, S. S. 2009. Impedance control of an active suspension system, Mechatronics, Vol. 19(1). 134-140. http://dx.doi.org/10.1016/j.mechatronics.2008.05.005

Fialho, I.; Balas, G. J. 2002. Road Adaptive Active Suspension Design Using Linear Parameter-Varying Gain-Scheduling, IEEE Transactions on Control Systems Technology 10(1): 43-54.

Fischer, D.; Isermann, R. 2003. Mechatronic semi-active and active vehicle suspensions, Control Engineering Practice 12: 1353-1367.

https://doi.org/10.1016/j.conengprac.2003.08.003

Fleming, B. 2014. An Overview of Advances in Automotive Electronics, Vehicular Technology Magazine IEEE, Vol. 9. 4-9. http://dx.doi.org/10.1109/MVT.2013.2295285

Flores, L.; Drivet, A.; Ramirez-Mendoza, R.; Sename, O.; Poussot-Vassal, C.; Dugard, L. 2006. Hybrid optimal control for semi-active suspension systems, In Proceedings of the 10th Mini Conference on Vehicle System Dynamics, Identification and Anomalies, Budapest, Hungary.

Göhrle, C.; Schindler, A.; Wagner, A.; Sawodny, O. 2015. Road Profile Estimation and Preview Control For Low-Bandwidth Active Suspension Systems, IEEE/ASME Transactions on Mechatronics 20(5): 2299-2310.

Guglielmino, E.; Sireteanu, T.; Stammers, C. W.; Ghita, G. Giuclea, M. 2008. Semi-active Suspension Control, Springer-Verlag London Limited: 302 p.

http://dx.doi.org/10.1007/978-1-84800-231-9 
Hac, A.; Youn, I. 1992. Optimal semi-active suspension with preview based on quarter car model, Journal of Vibration and Acoustic, 114: 85-92.

Harris, N. K.; Gonzalez, A.; O`Brien, E. J.; McGetrick, P. 2010. Characterisation of pavement profile heights using accelerometer readings and a combinatorial optimisation technique, Journal of Sound and Vibration 329: 497-508.

http://dx.doi.org/10.1016/j.jsv.2009.09.035

Hong, K. S.; Sohn, H. C.; Hendrick, J. K. 2002. Modified Skyhook Control of Semi-Active Suspensions: A New Model, Gain Scheduling, and Hardware-in-the-Loop Tuning, Journal of Dynamic Systems, Measurement, and Control 124(1): 158-167. http://dx.doi.org/10.1115/1.1434265

Huisman, R. G. M.; Veldpaus, F. E.; van Heck, J. G. A. M.; Kok, J. J. 1993. Preview Estimation and Control for (Semi-) Active Suspensions, Vehicle System Dynamics, 22: 335-346. DOI: 10.1080/00423119308969035

Yao, J.; Zheng, J. 2006. Semi-active Suspension System Design for Quarter-car Model using Model Reference Sliding Mode Control, IEEE International Conference on Vehicular Electronics and Safety. 398-402. http://dx.doi.org/10.1109/ICVES.2006.371623

Ihsan, S. I.; Ahmadian, M.; Faris, W. F.; Blancard, E. D. 2009. Ride performance analysis of half-car model for semi-active system using RMS as performance criteria, Shock and Vibration 16: 593-605. DOI 10.3233/SAV-2009-0491

Ingress Protection (IP) and what it means [interaktyvus]. 2019. [žiūrèta 2019-01-29]. Prieiga per interneą: <http://www.dsmt.com/resources/ip-rating-chart/>.

Yinlong, H.; Michael, Z. Q. C.; Yonghui, S. 2017. Comfort-oriented vehicle suspension design with skyhook inerter configuration, Journal of Sound and Vibration 405: 34-47.

ISO 8608:1995. Mechanical vibration - Road surface profiles - Reporting of measured data.

Yuan, Z.; Zhang, X.; Liu, S.; Han, X.; Du.; Y. 2015. Laser Line Recognition for Autonomous Road Roughness Measurement, The 5th Annual IEEE International conference on Cyber Technology in Automation, Control and Inteliigent Systems: 436-440. http://dx.doi.org/10.1109/CYBER.2015.7287977

Karnopp, D. C.; Crosby, M. J.; Harwood, R. A. 1974. Vibration control using semi-active force generators, J Eng Ind 97: 619-626.

Kashem, S. B. A.; Chowdhury, M. A.; Choudhury, T. A.; Ektesabi, M.; Nagarajah, R. 2015. Study and Review on Vehicle Suspension Control Theories and Introduction of Novel Adaptive Skyhook Control System, Australian Journal of Basic and Applied Sciences, 9(30): $1-12$.

Kashem, S. B. A.; Chowdhury, M. A.; Choudhury, T. A.; Ektesabi, M.; Nagarajah, R. 2015. Study and Review on Vehicle Suspension Control Theories and Introduction of Novel Adaptive Skyhook Control System, Australian Journal of Basic and Applied Sciences, 9(30): 1-12. 
Khot, S. M.; Patil, S.; Bhaye, N. A. 2017. Simulation study of MR Damper for Bump Road Profile, International Conference on Nascent Technologies in the Engineering Field.

Kilic, F.; Hilsmann, J. 2016. Application and Improvement of the TRRL (Transport and Road Research Laboratory) High-Speed Laser Profilometer Algorithm with Sensor Fusion, IFAC (International Federation of Automatic Control) PapersOnLine 49(15): 260265. http://dx.doi.org/10.1016/j.ifacol.2016.07.761

Kistler Group, 2012. Kistler HF Sensor Instruction Manual. Switzerland.

Kitching, K. J.; Cebon, D.; Cole, D. J. 1999. An Experimental Investigation of Preview Control, Vehicle System Dynamics 32(6): 459-478.

http://dx.doi.org/10.1076/vesd.32.6.459.4226

Koulocheris, D.; Papaioannou, G.; Chrysos, E. 2017. A comparison of optimal semi-active suspension systems regarding vehicle ride comfort, IOP Conf. Series: Materials Science and Engineering 252. DOI: 10.1088/1757-899X/252/1/012022

Krauze, P.; Kasprzyk, J. 2016a. Comparison of linear and nonlinear feedback control for a half-car model with MR dampers, $21^{\text {st }}$ International Conference and Models in Automation and Robotics (MMAR), 965-970. http://dx.doi.org/10.1109/MMAR.2016.7575268

Krauze, P.; Kasprzyk, J. 2016b. Mixed Skyhook and FxLMS control of a half-car model with magnetorheological dampers, Advances in Acoustics and Vibration. DOI: http://dx.doi.org/10.1155/2016/7428616

Levulyte, L.; Žuraulis, V.; Sokolovskij, E. 2014. The research of dynamic characteristics of a vehicle driving over road roughness, Eksploatacjai Niezawodnosc-Maintenance and Reliability 16 (4): 518-525

Li, G.; Chen, N. 2018. Study on nonlinear dynamic characteristics of wheel shimmy of 4WID electric vehicle with nonlinear damping and stiffness, 2018 Chinese Control And Decision Conference (CCDC): 1692-1697. DOI: 10.1109/CCDC.2018.8407400

Liu, H.; Gao, H.; Li, P. 2014. Handbook of vehicle suspension control systems. London: The Institution of Engineering and Technology. 408 p.

Liu, Y.; Waters, T. P.; Brennan, M. J. 2005. A comparison of semi-active damping control strategies for vibration isolation of harmonic disturbances, Journal of Sound and Vibration 280: 21-39. http://dx.doi.org/10.1016/j.jsv.2003.11.048

Ma, B.; Yang, D.; Gong, D.; Wei, Z. 2017. Lugre model for a magneto-rheological (MR) fluid damper, 2017 International Conference on Advanced Mechatronic Systems (ICAMechS): 1-4. DOI: 10.1109/ICAMechS.2017.8316476

Martinez-Arroyo, M.; Enrique Sucar, L. 2006. Learning an Optimal Naive Bayes Classifier, The 18th International Conference on Pattern Recognition. http://dx.doi.org/10.1109/ICPR.2006.748 
Marzbanrad, J.; Poozesh, P.; Damroodi, M. 2013. Improving vehicle ride comfort using an active and semi-active controller in a half-car model, Journal of Vibration and Control 1-21. http://dx.doi.org/10.1177/1077546312441814

Morselli, R.; Zanasi, R. 2008. Control of a port hamiltonian systems by dissipative devices and its application to improve the semi-active suspension behaviour, Mechatronics, 18(7): 364-369. DOI: 10.1016/j.mechatronics.2008.05.008

Mostaani, S.; Singh, D.; Firouzbakhsh, K.; Ahmadian, M. T. 2011. Optimization of a passive vehicle suspension system for ride comfort enhancement with different speeds based on DOE method, Proc. of Int. Colloquiums on Computer Electronics Electrical Mechanical and Civil: 149-154. http://dx.doi.org/02.CEMC.2011.01

Mulla, A. A.; Unaune, D. R. 2013. Active suspensions future trend of automotive suspensions, International Conference on Emerging Trends in Technology \& Its Applications.

O`Brien, E. J.; McGetrick, P.; Gonzalez, A. 2010. Identification of Road Irregularities via Vehicle Accelerations, Transport Research Arena Europe 2010.

Pakalnis, A.; Dimaitis, M. 2001. Kelio dangos lygumo vertinimas Lietuvoje. Lietuvos keliai. Lietuvos automobilių kelių direkcija prie Susisiekimo ministerijos. Vilnius. 52-56 p.

Patel, M.; Gundaliya, P. J. 2017. A study on speed breakers, International Journal of Advance Engineering and Research Development 4 (3): 368-372.

Paukštè, J. 2015. Strateginio planavimo ir vystymo modelio analize, vertinimas ir taikymas Šiauliu regiono magistraliniu keliu tinklo valdymui. Vilnius. 77 p.

Pei, Q.; Na, J.; Huang, Y.; Gao, G.; Wu, X. 2016. Adaptive Estimation and Control of MR damper for Semi-Active Suspension Systems, $35^{\text {th }}$ Chinese Control Conference, 31113116. http://dx.doi.org/10.1109/ChiCC.2016.7553836

Pepe, G.; Carcaterra, A. 2016. VFC - Variational Feedback Controller and its application to semi-active suspensions, Mechanical Systems and Signal Processing 76-77: 72-92. http://dx.doi.org/10.1016/j.ymssp.2016.01.002

Phalke, T. P.; Mitra, A. C. 2016. Comparison of passive and semi-active suspension system by MATLAB SIMULINK for different road profiles, IOSR Journal of Mechanical \& Civil Engineering: 38-43.

Pikosz, H.; Ślaski, G. 2010. Charakterystyki elementów sprężystych i tłumiących zawieszenia samochodu osobowego oraz zastępcze charakterystyki ich modeli, Logistyka, systemy transportowe, bezpieczeństwo w transporcie - LOGITRANS. 1-10.

Ploechl, M.; Mastinu, G. 2014. Road and off-Road Vehicle System dynamics Handbook. CRC Press, Taylor \& Francis Group: 1382-1397.

Polyuga, R. V.; Schaft, A. 2010. Structure preserving model reduction of port - Hamiltonian systems by moment matching at infinity, Automatica 46: 665-672. DOI: 10.1016/j.automatica.2010.01.018

Prashant, R. P.; Arun, T. M.; Saraf, M. R. 2018. IRI (International Roughness Index): An Indicator Of Vehicle Response, Materials Today: Proceedings 5(5): 11738-11750. 
Rao, T. R. M.; Rao, G. V.; Rao, S.; Purushottam, A. 2010. Analysis of Passive and Semi Active Controlled Suspension Systems for Ride Comfort in an Omnibus Passing over a Speed Bump, International Journal of Research \& Reviews in Applied Sciences 5(1): 717.

Sayers, M. W.; Karamihas, S. M. 1996. Interpretation of road roughness profile data. Final Report SPR-2. Federal Highway Administration: $159 \mathrm{p}$

Sayers, M. W.; Karamihas, S. M. 1998. The Little Book of Profiling. Basic Information about Measuring and Interpreting Road Profiles. Michigan: 100 p.

Sammier, D.; Sename, O.; Dugard, L. 2003. Skyhook and H8 Control of Semi-active Suspensions: Some Practical Aspects, Vehicle System Dynamics 39(4): 279-308.

Sande, T. P. J.; Besselink, I. J. M.; Nijmeijer, H. 2016. Rule-based control of a semi-active suspension for minimal sprung mass acceleration: design and measurement, Vehicle System Dynamics 54(3): 281-300. DOI: 10.1080/00423114.2015.1135970

Savaresi, S. M.; Poussot-Vassal, C.; Spelta, C.; Sename, O.; Dugard, L. 2010. Semi-Active Suspension Control Design for Vehicles. Boston: Butterworth-Heinemann/Elsevier. 206 p.

Savaresi, S. M.; Spelta, C. 2009. A single-sensor control strategy for semi-active suspensions, IEEE Transactions on control systems technology 17(1): 143-152.

Savaresi, S.; Bittanti, S.; Montiglio, M. 2005. Identification of semi-physical and blackbox non-linear models: the case of MR-dampers for vehicles control, Automatica 41: 113117.

Savaresi, S.; Silani, E.; Bittanti, S. 2004. Semi-active suspensions: an optimal control strategy for a quarter-car model, In Proceedings of the 1st IFAC Symposium on Advances in Automotive Control (AAC): 572-577.

Schindler, A. 2009. Neue Konzeption und erstmalige Realisierung eines aktiven Fahrwerks mit Preview-Strategie, ser. Schriftenreihe des Instituts für Angewandte Informatik, Automatisierungstechnik am Karlsruher Institut für Technologie. Karlsruhe: KIT Scientific Publ.

Shamsi, A.; Choupani, N. 2008. Continuous and Discontinuous Shock Absorber Control through Skyhook Strategy in Semi-Active Suspension System (4DOF Model), Mechanical and Mechatronics Engineering 2(5): 697-701.

Sivilevičius, H.; Bražiūnas, J.; Prentkovskis, O. 2017. Technologies and principles of hot recycling and investigation of preheated reclaimed asphalt pavement batching process in an asphalt mixing plant, Applied sciences. Basel: MDPI AG 7(11): 1-20.

Sivilevičius, H.; Vansauskas, V. 2013. Research and evaluation of ruts in the asphalt pavement on Lithuanian highways, Journal of civil engineering and management 19(5): 609-621.

Skačkauskas, P.; Žuraulis, V. 2015. Research of characteristics of sports cars' shock absorbers, Transport Means 2015: proceedings of the 19th international conference: 231235. 
Skačkauskas, P.; Žuraulis, V.; Vadluga, V.; Nagurnas, S. 2017. Development and verification of a shock absorber and its shim valve model based on the force method principles, Eksploatacja i Niezawodnosc - Maintenance and Reliability 19(1): 126-133.

Skrickij, V.; Savitski, D.; Ivanov, V.; Skačkauskas, P. 2018. Investigation of cavitation process in monotube shock absorber, International journal of automotive technology. Basel 19(5): 801-810.

Ślaski, G. 2010. Damping parameters of suspension of a passeneger vehicle equiped with semi-active dampers with a by-pass valve, Transport Problems 4(1): 87-94.

Ślaski, G. 2011. The influence of adaptive damping level on vehicle vibration comfortpassenger car experimental tests results, The $7^{\text {th }}$ International Conference "Transbaltica 2011 ": 200-205.

Sohn, H.; Hong, K.; Hedrick, J. 2000. Semi-active control of the Macpherson suspension system: Harware-in-the-loop simulations, International Conference on Control Applications: 982-987.

Souza, R. O.; Neto, S. D.; Farias, M. M. 2006. Improving Pavements With Long-Term Pavement Performance: Products for Today and Tomorrow, Papers From the 2003-2004 International Contest on Long-Term Pavement Performance Data Analysis: 5-6.

Sugai, H.; Buma, S.; Kanda, R.; Yoshioka, K.; Hasegawa, M. 2012. Preview Ride Comfort Control for Electric Active Suspension, Proceedings of the FISITA 2012 World Automotive Congress, Lecture Notes in Electrical Engineering 198: 147-161.

Suzuki, T.; Takahashi, M. 2012. Semi-Active Suspension Control Considering Lateral Vehicle Dynamics Due to Road Input, New Advances in Vehicular Technology and Automotive Engineering, 359-376. http://dx.doi.org/10.5772/45789

Takaba, K. 2003. A Tuturial on Preview Control Systems, SICE Annual Conference in Fukui: 1388-1393.

Tawwab, A. 2013. Theoretical and experimental fuzzy control on vehicle pneumatic semiactive suspension system, Journal of American Science, 9(1): 498-507.

Tudón-Martínez, J. C.; Fergani, S.; Sename, O.; Morales-Menendez, R.; Dugard, L. 2014. Online Road Profile Estimation in Automotive Vehicles, 2014 European Control Conference (ECC): 2370-2375.

Valasek, M.; Kortum, W. 2002. The Mechanical Systems Design Handbook: Modeling, Measurent and Control. CRC Press LLC.

Verlag, C. H. 2014. Fahrkomfort der extraklasse, Hanser Automotive Vol. 11. 46-47.

Wang, H. P.; Ghazally, I. Y. M.; Tian, Y. 2018. Model-free fractional-order sliding mode control for an active vehicle suspension system, Advances in Engineering Software 115: 452-461. https://doi.org/10.1016/j.advengsoft.2017.11.001

Więckowski, D.; Dąbrowski, K.; Ślaski, G. 2018. Adjustable shock absorber characteristics testing and modelling. In IOP Conf. Series: Materials Science and Engineering 421: 1-10. https://doi.org/10.1088/1757-899X/421/2/022039 
Williams, R. A. 1994. Electronically controlled automotive suspensions, Computing \& Control Engineering Journal, 143-148.

Wang, W.; Hou, Z. 2019. Physical Parametric Model of an Automotive Electrohydraulic Semiactive Damper, IEEE Transactions on Vehicular Technology: 1-10. https://doi.org/10.1109/TVT.2019.2907523

Wong, J. Y. 2008. Theory of Ground Vehicles. John Wiley \& Sons, 560 p.

ZF Friedrichshafen AG. 2011. CDC - Continuous Damping Control For greater safety and comfort [online]. Prieiga per internetą: <http://www.zf.com>. [cituota 2016 m. vasario $2 \mathrm{~d}$.].

Zhu, Q.; Ayalew, B. 2014. Predictive Roll, Handling and Ride Control of Vehicles via Active Suspensions, American Control Conference, 2102-2107. http://dx.doi.org/10.1109/ACC.2014.6859037

Žuraulis, V.; Levulytė, L. 2014. The influence of comfort and sport driving modes of modern vehicles on the vibration of sprung and unsprung masses, Transport Means 2014: proceedings of the 18th international conference: 15-19.

Žuraulis, V., Levulyte, L., Sokolovskij, E. 2014. The impact of road roughness on the duration of contact between a vehicle wheel and road surface, Transport 29(4): 431-439. http://dx.doi.org/10.3846/16484142.2014.984330

Žuraulis, V.; Sokolovskij, E. 2018. Vehicle velocity relation to slipping trajectory change: an option for traffic accident reconstruction, Promet - Traffic \& Transportation 30(4): 395-406. https://doi.org/10.7307/ptt.v30i4.2720 



\section{Autoriaus mokslinių publikacijų disertacijos tema sąrašas}

\section{Straipsniai recenzuojamuose mokslo žurnaluose}

Surblys, V.; Žuraulis, V.; Sokolovskij, E. 2017. Estimation of road roughness from data of on-vehicle mounted sensors, Eksploatacja i Niezawodnosc - Maintenance and Reliability 19(3): 369-374. ISSN 1507-2711. DOI: 10.17531/ein.2017.3.7 (Clarivate Analytics Web of Science, Impact Factor 1,383).

Žuraulis, V.; Surblys, V.; Šabanovič, E. 2019. Technological measures of forefront road identification for vehicle comfort and safety improvement, Transport 34(3): 363-372. ISSN 1648-4142, eISSN 1648-3480. DOI: 10.3846/transport.2019.10372 (Clarivate Analytics Web of Science, Impact Factor 1,267).

Surblys, V.; Žuraulis, V.; Sokolovskij, E. 2019. The influence of semi-active suspension adjustment on vehicle body pitch oscillations, Transport and Telecommunication 20(2): 107-113. ISSN 1407-6160, eISSN 1407-6179. DOI 10.2478/ttj-2019-0009 (Clarivate Analytics Web of Science).

Surblys, V.; Ślaski, G.; Pikosz, H. 2018. The usage of a laser height sensor for estimating road unevenness profile, The archives of automotive engineering = Archiwum motoryzacji 79(1): 95-106. ISSN 1234-754X.

Surblys, V.; Sokolovskij, E. 2018. Lengvujų automobilių pasyvių ir pusiau aktyvių pakabų tyrimas, Mokslas - Lietuvos ateitis: Transporto inžinerija ir vadyba 10: 1-5. ISSN 20292341, eISSN 2029-2252. DOI: 10.3846/mla.2018.6050. 
Janhar, U.; Navikas, D.; Surblys, V. 2018. Comparative analysis of semi-active suspension control, Inžinerinés ir edukacinès technologijos = Engineering and educational technologies 10(2): 93-99. ISSN 2029-9303.

Mužar, M.; Surblys, V.; Navikas, D. 2018. A comparison of passive and semi-active mathematical car models, Inžinerinès ir edukacinés technologijos = Engineering and educational technologies 10(2): 131-136. ISSN 2029-9303.

\section{Straipsniai kituose leidiniuose}

Levulytė, L.; Žuraulis, V.; Surblys, V. 2016. The influence of suspension regulation modes to body pitch angle of braked vehicle, 12 Tarptautine moksline praktine konferencija, 2016 m. rugséjo 29-30 d. Varšuvos universitetas: 534-546, ISBN 9789986555438. 


\section{Summary in English}

\section{Introduction}

\section{Formulation of the problem}

New vehicle manufacturing technologies enable to improve the traffic safety and the comfort for a driver and passengers. An important factor is a contact of the tyre with the road surface on movement of the vehicle on different pavements and road irregularities of various shapes. It is influenced by the tyres, the stiffness and damping elements of the suspension system, the structure and many other components.

Manufacturers of vehicles and scientists widely pay a particular attention to an analysis of the dynamic processes in the suspension as well as to its structural improvement. Passive suspensions are replaced with semi-active or active suspensions. Supplemental appliances for improving an operation of the suspension are used as well. New control algorithms for improving operation of elements of the suspension are being created.

Vehicle manufacturers frequently apply the semi-active suspension control algorithm "Skyhook" that ensures more safe and comfortable movement of the vehicle, as compared to a vehicle with a passive suspension. The key imperfection of the "Skyhook" principle of control: the characteristics of the suspension are altered when the wheel just comes down on a road irregularity, so it would be purposeful to change the dampness of the shock absorbers before the wheel enters in contact with the road irregularity. For this purpose, additional sensors for identifying the height of road irregularities shall be used. They can be laser distance sensors. The sensor may be fixed on sprung and unsprung masses. However, while measuring the distance from the sprung mass of the vehicle to 
the road surface, one is confronted with certain difficulties. The body of a vehicle vibrates on its acceleration, braking and manoeuvring. In addition, the signal is distorted when the wheels of the vehicle come down on a road irregularity. So, prior to using a signal from the laser sensor, it should be corrected first of all. The other very important stage is application of the signal for improving an operation of the electronically controllable suspension. To improve control and operation of the suspension, a special algorithm for assessing future irregularities of the road and an instantaneous position of the vehicle should be created.

\section{Relevance of the thesis}

An improvement of operation of an electronically controllable suspension is closely related to road traffic safety. Introduction of new technologies in new models of vehicles enables to improve their safety and their comfortability for the driver and the passengers. An identification of the road surface status before the vehicle comes down on a road irregularity enables to prepare electronically controllable damping elements in accordance with the future conditions. In such a way, road irregularities with less intensive vertical vibrations of sprung mass are moved beyond and cohesion of the wheel with the road surface is maintained. In addition, the accumulated knowledge of the suspension's operation upon the real conditions enables to forecast the vibrations of sprung and unsprung masses while moving on a certain pavement.

Identification of a road irregularity on movement of the vehicle enables collecting the data on the conditions of the roads; if the said data are transferred to other vehicles or elements of the infrastructure, they shall affect their performance as well. The road information can be transmitted to the road supervision enterprises and the latter shall improve the condition of the roads.

\section{The object of the research}

The object of the research includes a car with road surface identification function and semi-active suspension dynamic parameters of such a car moving on rough road pavement.

\section{The aim of the thesis}

After the investigation of the semi-active suspension, to create an algorithm that enables identifying road irregularities, reducing the vertical oscillations of the car caused by them.

\section{The tasks of the thesis}

For an implementation of the aim of the thesis, the following tasks were set:

1. To analyse the control methods for semi-active shock absorbers and the ways for road irregularities identification.

2. To improve the mathematical longitudinal half-car model as follows: to introduce the road irregularities identification in the model with nonlinear characteristics of stiffness and damping elements and a delay of shock absorbers.

3. To create a compensation algorithm for road surface irregularities identification on a movement with a constant velocity. 
4. Upon applying the obtained information on road irregularities and the improved system control algorithms, to reduce vertical oscillations of the car (improvement of control of the semi-active suspension of the car).

5. To choose an appropriate position for mounting a laser distance sensor on the sprung mass of the car that is fit for the road profile identification when the wheel comes down on the road irregularity.

6. To experimentally investigate and compare the dynamic parameters of a moving car with a known and improved semi-active suspension control algorithm.

\section{The research methodology}

In the thesis, theoretical and experimental research methods are applied:

In the theoretical part, methods of mathematical modelling were applied. Software package Matlab/Simulink was used to calculate dynamic parameters of the moving car; an analysis of the results was carried out upon applying other Matlab complements, such as Curve Fitting and Signal Analysis.

The experimental tests were carried out for three vehicles. For fixing the dynamic parameters, the equipment from Corrsys-Datron, Kistler, dSpace and other manufacturers was used. The tests were fixed by camera Garmin VIRB with slow operation function.

\section{Scientific novelty of the thesis}

On preparation of the thesis, the following results innovative for transport engineering were obtained:

1. The mathematical half-car model with a supplemental laser distance sensor had been improved. The model was validated by the relevant experimental tests. The damping and stiffness elements were described by nonlinear functions; the additionally introduced delay of the damping elements affected the dynamics of the sprung mass.

2 . The created compensatory algorithm enables to eliminate mathematically the vibrations of the sprung mass appearing on acceleration or braking of the car or when it comes down on the road irregularities. So, the height and the shape of such irregularities can be measured.

3. The appropriate position for fixing a laser distance sensor on the sprung mass of the car had been established.

4. Semi-active suspension, with improved algorithms and road irregularities identification, reduces vehicle vertical vibrations that depend on the road surface.

\section{Practical value of the research findings}

The obtained results of the research enable to extend the knowledge of the vehicle movement dynamics on alteration of the damping forces of the shock absorbers.

The improved half-car mathematical model with a fixed supplemental laser distance sensor can be used for tests of a car suspension systems.

The chosen best version of the improved semi-active suspension control algorithms can be introduced in designing of a car with a semi-active suspension and a road unevenness identification system. 
Measurement of the road surface and processing of the results by a vibration compensatory model enable using the results for an improved control of the semi-active suspension. In addition, the data on the road surface condition in the real time can be used in operation of safety systems of other vehicles or transmitted to innovative road infrastructure systems or enterprises involved in road supervision.

\section{Defended statements}

1. In order to obtain the road surface unevenness data of the highest possible accuracy, it is necessary to compensate the vibrations and the vertical displacements of the vehicle related to traffic of vehicles the results provided by the laser distance sensor fixed on the body of a car.

2. Upon applying the half-car mathematical model with a supplemental laser distance sensor, it is possible to establish the height and the shale of the road irregularity and to assess the position of the car in the real time.

3 . The data on the road surface before the wheel comes down on the road irregularities can be used for improving a control algorithm usable for electronically controllable shock absorbers.

4. On applying mathematical modelling for analysis the suspension systems of a car, the damping and stiffness elements shall be described by nonlinear functions and a delay of shock absorbers of mechanical and electrical systems shall be introduced.

\section{Approval of the research findings}

Eight scientific papers were published on the subject of the thesis: three of them appeared in scientific journals included in Clarivate Analytics Web of Science database (Surblys et al. 2019, Žuraulis et al. 2019, Surblys et al. 2017); four - in other publications of international databases (Surblys et al. 2018; Surblys, Sokolovskij 2018; Mužar et al. 2018; Janhar et al. 2018); and one - in the reviewed materials of the international conference (Levulyte et al. 2016).

The described results of the research in the thesis were presented at four scientific conferences held in Lithuania and abroad:

- the 12th international scientific practical conference "Criminalistics and forensic expertology: science, studies, practice" in Warsaw (Poland), 2016;

- the 13th safety conference "XIII Międzynarodową konferencję hamulcową $\mathrm{i}$ bezpieczeństwa" in Lodz (Poland), 2017;

- the 21 st conference of young scientists "Science - the future of Lithuania. Transport engineering and management" in Vilnius, 2018;

- the international conference "Vision Zero for Sustainable Road Safety in Baltic Sea Region" in Vilnius, 2018.

\section{The structure of the dissertation}

The thesis consists of the introduction, three chapters and general conclusions. In addition, five annexes are enclosed.

The thesis includes 129 pages, excluding annexes, 59 numbered formulas, 66 figures and 11 tables. In course of preparation of the thesis, 113 literature references were used. 


\section{Review of a car with semi-active suspension controls}

The suspension of the vehicle shall: withstand the total static weight of the vehicle; ensure the best possible cohesion between the tyre and the road surface; ensure sufficient steering; reduce the body tilting; ensure comfortability for the passengers and good controllability of the vehicle (Rajamani 2006, Wong 2001).

A classic suspension of a vehicle usually includes three elements (Savaresi et al. 2010):

- a stiffness element - most frequently, it is a cylindrical spring that opposes to elongation and compression of the suspension. This element is affected by the total static load.

- a damping element - most frequently, it is a hydraulic shock absorber that damps vibrations of the sprung mass (Skačkauskas et al. 2017).

- mechanical elements that connect unsprung elements of the suspension with the sprung element (the body of the vehicle).

In a classic suspension, passive damping elements are used. A passive suspension is not able to alter the damping and stiffness forces when the vehicle is moving, because no supplemental energy source is used for the damping elements. The structure of a suspension of this type is simple (Skrickij et al. 2018). The costs of its production are lower as compared to a semi-active or an active suspension. Such a suspension is usually used in cars. Because a passive suspension is not able to alter the damping and stiffness forces, it can ensure the set working conditions at the foreseen damping (Skačkauskas, Žuraulis 2015).

In the shock absorbers of a semi-active suspension, the force can be changed in two ways: by increasing or decreasing the cross-section of the hole in the shock absorber; or; by changing the viscosity of the liquid (Wong 2008). In a semi-active suspension, two acceleration sensors are used: the first sensor is fixed to the unsprung mass (usually to a hub of a wheel or to the shock absorber) and the second sensor - in the sprung mass, i.e. in the body of the vehicle. Usually, individual acceleration sensors are used for each wheel of the vehicle; however, the only acceleration sensor of the body sometimes is used for two rear wheels (ZF Friedrichshafen AG. 2011). In addition, a system with a single acceleration sensor is discussed upon as well (Savaresi, Spelta 2009). The control block processes the data according to the obtained parameters and sends a signal to the shock absorber.

In literature, the principle of suspension control with identification of the road irregularities before the vehicle comes down on the road surface is often referred to as "Preview Control" (Dąbrowski, Ślaski 2016; Kitching et al. 1999). For applying the said principle, lasers, cameras and ultrasonic sensors are used. Most frequently, this principle is applied for an active suspension upon striving to improve the comfortability of travelling (Valasek, Kortum 2002). Göhrle et al. (2015) used a laser sensor fixed to the windscreen for measuring the road irregularities before the vehicle comes down on the road surface under the measuring. The obtained signal was used for improving the operation of shock absorbers of the active suspension. The authors confronted problems related to identification of vibrations of the sprung mass of the vehicle. While moving on road irregularities, the body of the vehicle vibrated together with the sensor fixed to the windscreen. Another problem 
is filtering of signals obtained from the acceleration sensors and the gyroscope. The measured signals were highly noisy.

The other system (Fialho, Balas 2002) enables to change the operation of the active suspension thus improving the comfortability of travel, if the road irregularities are known. Control of the suspension is accomplished on two levels: by choosing characteristics of the the suspension when the damping force is minimum and when it is maximum.

Upon the real conditions, all mechanical systems are damped (Bogdevičius et al. 2012; Žuraulis; Levulyte 2014). The shock absorbers used in the suspension of the vehicle are chosen upon taking into account the type of the vehicle and its weight; they are designed with a natural (dynamically changing) value of dampness (Bogdevičius et al. 2016). According to the frequency, vibrations are divided into three groups (Chen et al. 2016):

- very low frequency - from 0 to $15 \mathrm{~Hz}$;

- low frequency - from $15 \mathrm{~Hz}$ to $150 \mathrm{~Hz}$;

- high frequency - over $150 \mathrm{~Hz}$.

Vibrations of certain frequencies are dangerous for a human. Particularly dangerous are vibrations of frequencies close to the natural frequency of the vibrations of parts of a human body. Upon striving to improve the travel comfortability for drivers and passengers, the frequency of vibrations in vehicles is low and conforms to the very low frequency group. According to ISO 2631 standard, the frequencies of vibrations in vehicle may be divided into four groups (Ślaski 2011):

- the peak resonant frequency of the body - from 1 to $2 \mathrm{~Hz}$;

- the peak resonant frequency of the body and the wheels - from 5 to $6 \mathrm{~Hz}$;

- the peak resonant frequency of the wheels - about $10 \mathrm{~Hz}$;

- a frequency above the peak resonant frequency of the wheels - about $16 \mathrm{~Hz}$.

An evenness of pavement is one of the key indicators of the road quality (Sivilevičius et al. 2017) that affects the traffic safety and the driving comfort. In addition, road irregularities affect the interaction between the tyre and the wheel (Celko et al. 2009). A road irregularity is a sum of deflections from the ideal longitudinal profile expressed in metes per kilometre. An evenness of pavement directly depends on the number and the size of the pavement defects (such as pits, patches, transversal, longitudinal and net cracks waves and so on) (Paukštė 2015).

For assessing the evenness of a road, the International Roughness Index (IRI) (Sivilevičius, Vansauskas 2013; Prashant et al. 2018; ISO 8608; ASTM E1926-08 2015) is used. IRI assesses the size of road irregularities and their number per unit of the length of the road.

\section{Numerical analysis of dynamic properties of a car with semi-active suspension and road irregularities identification system}

For the theoretical research, the half-car mathematical model was used (Savaresi et al. 2010). The author supplemented the model in order to apply it for analyzing the problem under discussion: in the distance $l_{l}$, a laser distance sensor was fixed. The laser sensor was directed towards the road surface in the angle of $90^{\circ}$. The data used in the mathematical 
model conform to the parameters of vehicle Opel Astra that was used for the experimental tests from time to time. The data on the vehicle were taken from software PC Crash 8.1 usable for investigation of traffic events. In this model, the sensor is fixed in 1 metre distance ahead the front axle. The said distance was chosen because of a typical structure of the car when the front axle is $0.7-1.1 \mathrm{~m}$ long. The front axle of vehicles used for the experimental tests was $0.7-0.96 \mathrm{~m}$ long. Using the assembling elements, the laser sensor was fixed in the distance of 1 metre from the front axle. The position of the laser sensor was perpendicular to the road surface when the vehicle does not move.

In literature, the stiffness and damping coefficients of a suspension for models of such a type are usually described by a linear function; however, upon striving for higher accuracy, these elements are described herein by nonlinear functions.

The semi-active shock absorbers used in the vehicles operate with a delay that is divided into two key groups:

- a delay of the strength of transmitted current from the control module to the valve of the shock absorbers and its activation;

- a delay of change of the value of the shock absorber's dampness.

An electric delay lasts for about $18 \mathrm{~ms}$ and a hydromechanical delay - for $55 \mathrm{~ms}$ on the average. The alteration of the damping forces differs, when the shock absorber operates in the modes of compressions and elongation. In case of compression, a higher spring stiffness force appears, so it is calculated that the alteration of the damping force of the shock absorber lasts for about $67 \mathrm{~ms}$. When a shock absorber operates in the mode of elongation, the duration of the alteration of the damping force is about $43 \mathrm{~ms}$ (Więckowski et al. 2018).

A delay of operation of the shock absorbers affects „Skyhook“ and other principles of controls that alter the damping force in the real time. The desirable values are achieved not by the moment when they are needed but after a certain delay. The proposed semiactive suspension control algorithms are free of the above-mentioned imperfection related to a delay of the suspension operation, because a signal of the desirable values is sent before the wheel comes down on the obstacle. It is supposed the damping forces of the shock absorber are altered within the maximum time $-0.073 \mathrm{~s}$.

When a vehicle moves out of turns, it mostly vibrates about its transversal axis, so this angle shall be compensated in order to get to know precisely the distance between the road surface and the body of the vehicle. For processing the signal of the laser sensor, a compensatory algorithm (Fig. S.2.1) had been developed; the said algorithm eliminates the following 3 parameters from the signal under measuring:

- the vertical displacement of the sprung mass in the centre of gravity;

- the vertical displacement of the sprung mass in the point of the laser sensor's fixation caused by a rotation about the transversal axis;

- the position of fixation (the fixation angle) of the laser sensor. 


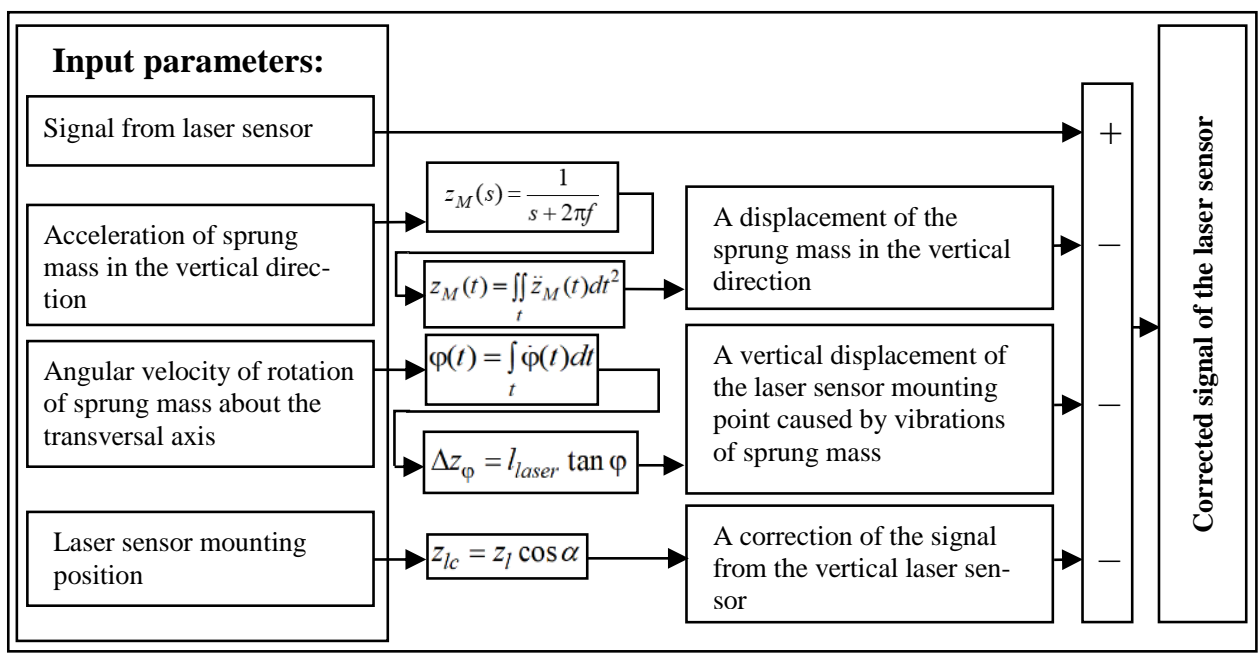

Fig. S.2.1. Laser height sensor signal compensation for vehicle body dynamics

After compensation of the signal obtained from the laser sensor, it is possible (if the real road surface profile is known) to alter the damping force of the shock absorbers for improving the comfortability of the driver and the passengers as well as the interaction between the wheel and road surface.

Below three created algorithms are presented. They enable (according to the earlier received signal from the laser sensor) altering the damping force of a semi-active shock absorber (after the compensation), thus ensuring an adaptability to the road irregularities. The models were developed in Matlab/Simulink, the alteration of the damping and stiffness forces was described by nonlinear functions and delays are specified for activation of the shock absorber. For a general case, the scheme of the control algorithm is shown in Fig. S.2.2 below.

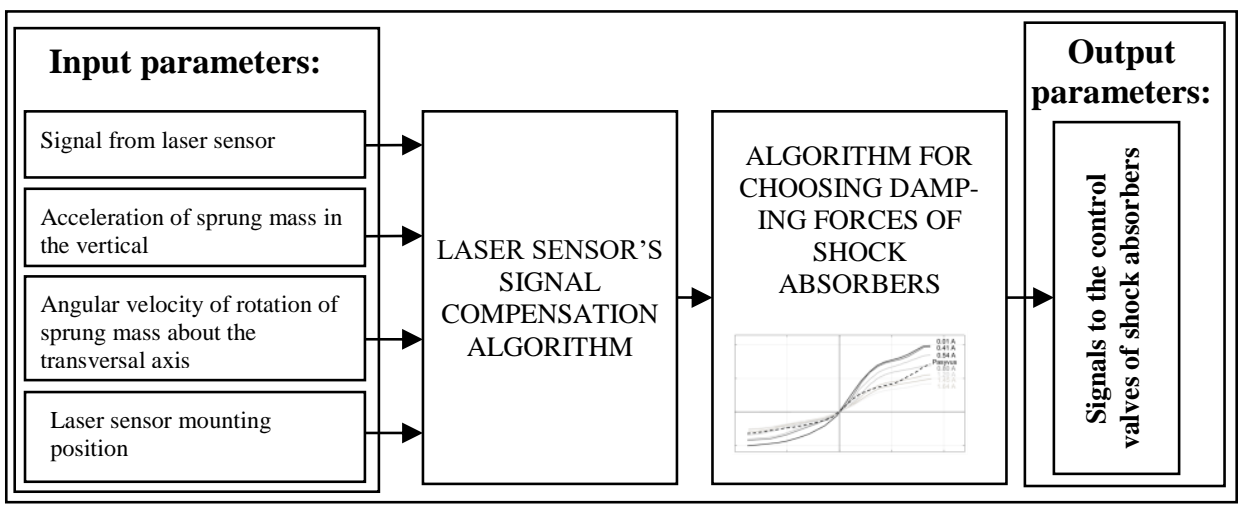

Fig. S.2.2. Semi-active suspension novel main algorithm scheme 
The Algorithm 1 for choosing the damping forces of the shock absorbers according to the found height of the road irregularities

The algorithm for choosing the damping forces operates on the base of previously chosen and set heights of road irregularities. It is shown in Fig. S.2.3, for that size of irregularities the relevant nonlinear function of damping forces is chosen. The theoretical research was carried out with $0.05 \mathrm{~m}$ high road irregularities and this value was divided into parts (in Fig. S.2.3: the axis with inscription The height of an irregularity).

According to the set height $z_{l}$ of the irregularity, the algorithm selects a nonlinear function of damping force of the shock absorber. If the height of the irregularity alters, another characteristic is selected. In the theoretical research, the damping force is applied at each time moment to the half-car mathematical model and in the real system - to the control valves for damping forces of the shock absorbers. The grade of opening of the valves directly depends on the strength of the current:

- at the minimum opening of a valve $-0.01 \mathrm{~A}$, the maximum damping forces of the shock absorber are generated;

- at $1.64 \mathrm{~A}$ - the minimum damping forces are generated, when the valve of the shock absorber is opened to the maximum extent and the discharge of the hydraulic liquid is maximum.

If this control algorithm is used in the real system, the characteristics of shock absorbers should be adjusted according to the height of road irregularities. The values shown in the diagram presented in Fig. S.2.3 above are fit for shock absorbers from ZF Sachs used in our experimental research or for shock absorbers from other manufacturers having similar characteristics. While analysing the results, this control algorithm is referred to as the Algorithm 1.

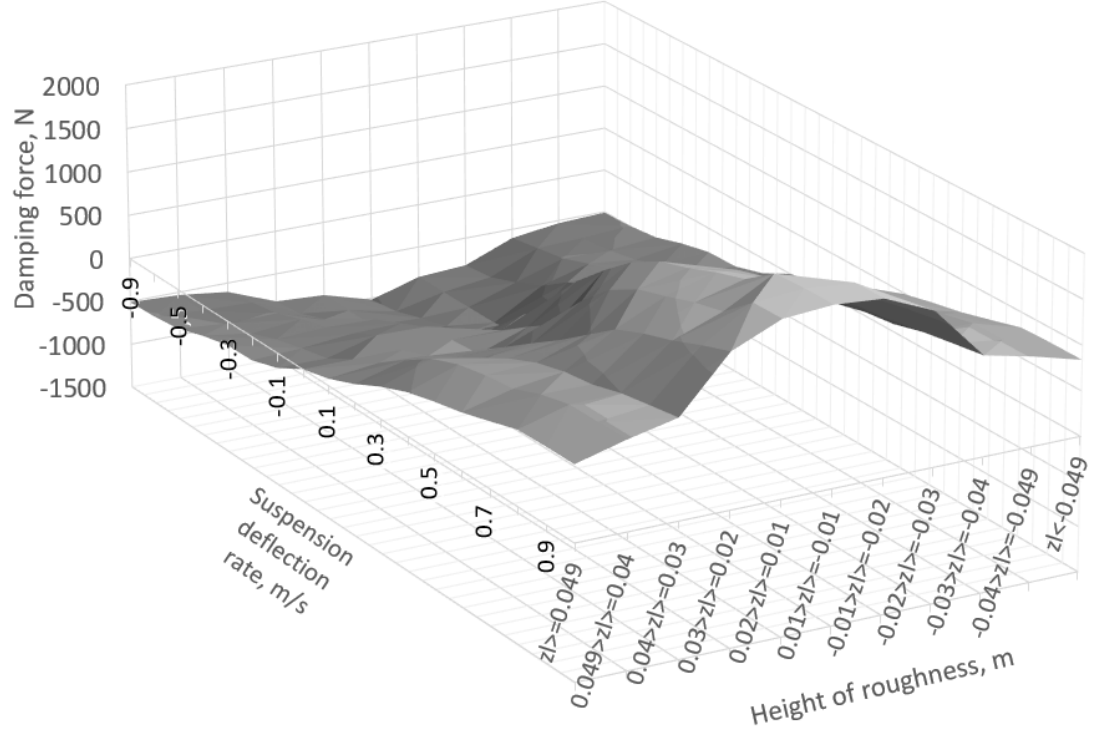

Fig. S.2.3. Damping force selection according to irregularity size of road 
The Algorithm 2 for selection of damping forces of shock absorbers according to the character of the established irregularities

This algorithm for selection of damping forces of shock absorbers operates according to the character of the established irregularities, i.e. when an increase of an irregularity is obtained, the maximum damping is set; on a decrease of an irregularity, the maximum damping is selected; and if the road is even - the average damping is selected. The algorithm observes the height alteration (the rate of the alteration), not the height of an irregularity (Fig. S.2.4).

The conditions of operation of the algorithm are described by the formula S.2.1:

$$
F_{c}(\Delta \dot{z})= \begin{cases}F_{c \text { min }}, & \operatorname{sign}\left(\dot{z}_{l}\right)>0, \\ F_{c \text { mid }}, & \operatorname{sign}\left(\dot{z}_{l}\right)=0, \\ F_{c \text { max }}, & \operatorname{sign}\left(\dot{z}_{l}\right)<0,\end{cases}
$$

here $F_{c}$ - the damping force of the semi-active shock absorber, $\dot{z}_{l}$ - the rate of alteration of the distance from the road surface to the laser sensor, $F_{c \max }$ - the maximum values of the damping force, $F_{c \text { min }}$ - the minimum values of the damping force, and $F_{c \text { vid }}-$ the average values of the damping force.

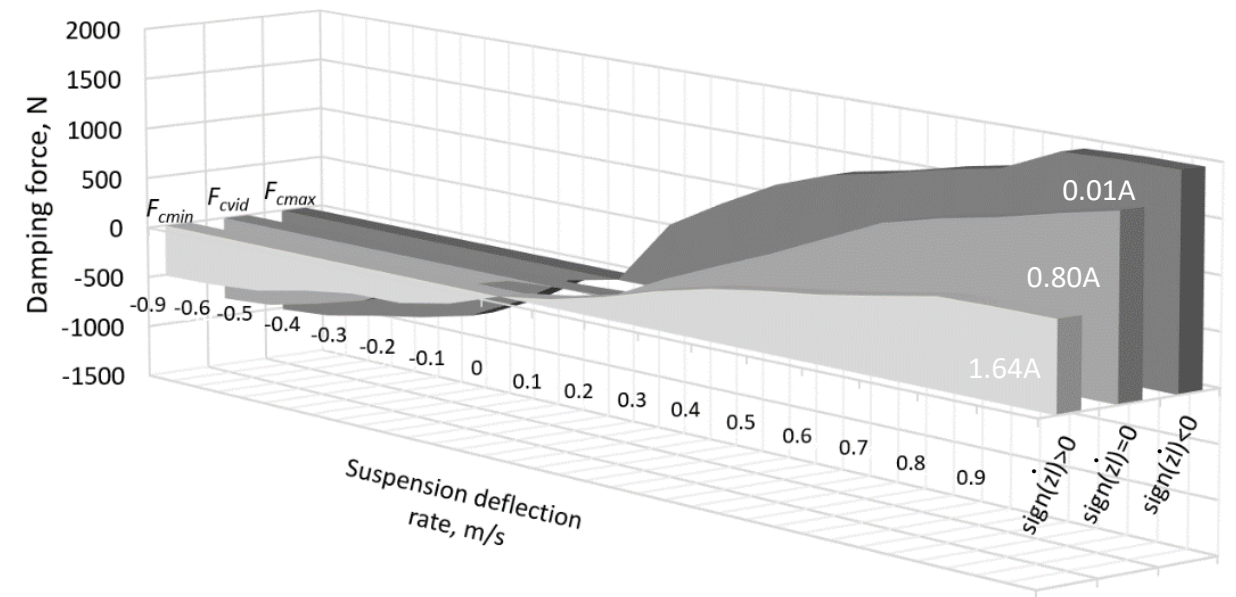

Fig. S.2.4. Damping force selection according to irregularity type of road

The advantage of this algorithm: no limitary heights of road irregularities should be specified for the system and no characteristics of assembled shock absorbers are needed to know. While analysing the results, this control algorithm is referred to as the Algorithm 2 . The additional condition for the algorithm: the driving velocity should not exceed $13.7 \mathrm{~m} / \mathrm{s}$. 
The Algorithm 3 for selection of damping forces of shock absorbers according to the maximum height of the irregularities and their character upon taking into account the velocity of movement.

This algorithm is similar to the above described ones; however, some supplemental conditions related to the velocity of movement are applicable to it.

When the velocity of the vehicle is $13.7 \mathrm{~m} / \mathrm{s}=49.3 \mathrm{~km} / \mathrm{h}$, the suspension control system can change the damping force of the shock absorber of a front wheel. At a higher velocity, measuring the road irregularities becomes relevant for a rear wheel of the vehicle only.

The algorithm is described according to the following conditions of operation:

The damping forces of a shock absorber are controlled for road irregularities over 0.02 m only:

$$
-0.02 \mathrm{~m}<\Delta l_{l}<0.02 \mathrm{~m} \rightarrow F_{c \text { vid }}
$$

When a vehicle moves on road irregularities with height of $0.02 \mathrm{~m}$, the vertical displacements are not transmitted to the unsprung mass, because the contact area between the tyre and the road surface is large.

If the velocity exceeds $13.7 \mathrm{~m} / \mathrm{s}$, the damping forces of the front shock absorbers shall be controlled upon following "Skyhook" principle:

$$
F_{c}= \begin{cases}F_{c \max }, & \dot{z}_{M}\left(\dot{z}_{M}-\dot{z}_{M 0}\right) \geq 0 \\ F_{c \min }, & \dot{z}_{M}\left(\dot{z}_{M}-\dot{z}_{M 0}\right)<0\end{cases}
$$

The damping forces of the rear shock absorbers shall be controlled according to the signal fixed by the laser sensor. The distance between the rear axle and the laser sensor is $3.61 \mathrm{~m}$; this distance is enough to alter the damping forces of the rear shock absorbers when the velocity of the vehicle is $49.5 \mathrm{~m} / \mathrm{s}$.

When irregularities increase, the minimum damping is selected and when they decrease - the maximum damping is selected:

$$
F_{c}= \begin{cases}F_{c \min }, & \operatorname{sign}\left(\dot{z}_{l}\right)>0, \\ F_{c \max }, & \operatorname{sign}\left(\dot{z}_{l}\right)<0 .\end{cases}
$$

The selection is made upon taking into account the rate of alteration of the irregularities' height.

The advantage of this control algorithm: no limitary heights of road irregularities should be specified for the system; however, when the algorithm is used for other vehicles, the critical velocities should be corrected upon taking into account the wheel base and the point of the laser sensor's mounting. The algorithm includes "Skyhook" control principle that eliminates an erroneous control of the front suspension at a velocity over $13.7 \mathrm{~m} / \mathrm{s}$. While analysing the results, this control algorithm is referred to as the Algorithm 3.

After the theoretical research with three algorithms, a passive suspension and semiactive suspension controlled by "Skyhook" algorithm, the generalised diagram of the control principles was formed. It is provided in Fig. S.2.5 below. For the suspension operating 
according to the Algorithm 2, the results are similar to those for the suspension that operates according to "Skyhook" control principle. The advantages of "Skyhook" manifest themselves for the sprung mass.

Among the developed algorithms, the best operating is the Algorithm 1. In a vehicle with a semi-active suspension controlled by the Algorithm 1, the pitch is the minimum; the vertical accelerations of unsprung masses are low. A displacement in the vertical direction is low, as compared to other control algorithms. It may be stated that the Algorithm 1 is oriented towards an improvement of the contact between the wheel and the road surface; the comfort of travelling is of a high level as well.

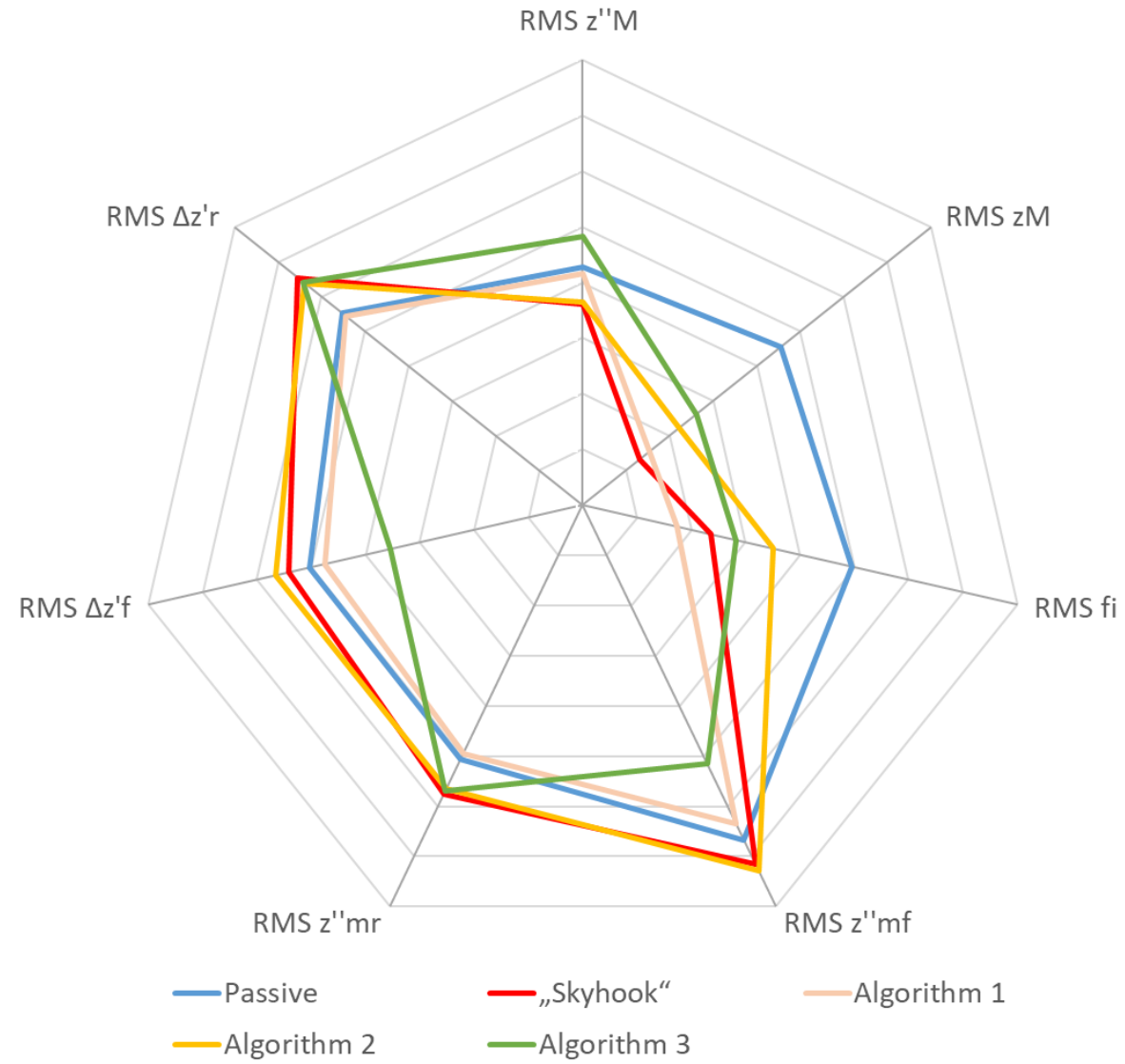

Fig. S.2.5. Root mean square values of different indicators in tested suspension control algorithms

When the Algorithm 2 is used, the pitch angle is large; the rates of deflections of the front and rear suspensions are high. The advantages of the Algorithm 3 manifest themselves in the dynamics of the front axle; however, its imperfections manifest themselves in the acceleration of the rear unsprung mass and the dynamics of the sprung mass. 


\section{Experimental research of a car with semi-active suspension}

The experimental research was accomplished in several stages. In the first stage of the research, it was strived to clear up the accuracy of the methodology usable for road irregularities identification. Three laser distance sensors were used in the research; the tests were carried out on the car Mercedes-Benz E350. In the second stage, it was strived to clear up the optimum point for laser sensor fixation. The tests were carried out on the car Audi A6. In the third stage, the research aimed to validate the developed half-car mathematical model. The experimental tests were carried out on the car Opel Astra. In the fourth stage, tests of the compensatory algorithm took place. They required supplemental equipment because of a necessity to carry out the calculations in the real time and to obtain a corrected signal from the laser sensor. For the said purpose, the car Opel Astra from Poznan University of Technology was used. The car was prepared by local scientists and equipped with integrated sensors and HIL (Hardware in the Loop) equipment from dSpace.

The experimental research of the fourth stage was carried out upon striving to assess an operation of the created compensatory algorithm in the real conditions. For the tests, a $70 \mathrm{~m}$ long of dry asphalt road was chosen. A road irregularity of a half-sinusoidal shape (height $0.05 \mathrm{~m}$ ) was selected as road excitation.

During the tests, the vehicle was moving with a constant velocity of $30 \mathrm{~km} / \mathrm{h}$. Upon striving for precise assessment of the compensatory algorithm, the tests were carried out at different settings of shock absorbers - the maximum and minimum damping forces.

In Figs S.3.1 and S.3.2 below, the obtained results of the tests with and without compensation are presented. The obtained curves show that the compensatory algorithm reduces vertical vibrations of the sprung mass and enables to assess the real road profile. In the both cases of the suspension control, the signal from the laser sensor after the compensation reflects the real height of the road irregularities. When the shock absorbers were set for the minimum damping, the laser sensor fixed an irregularity of $0.067 \mathrm{~m}$; after the compensation, the height of the irregularity conformed to $0.052 \mathrm{~m}$. When the shock absorbers were set for the maximum damping, the fixed height of the irregularity was $0.035 \mathrm{~m}$, after the compensation $-0.052 \mathrm{~m}$. In the both cases, the height of the irregularity after the compensation was $96.4 \%$ of the real height.

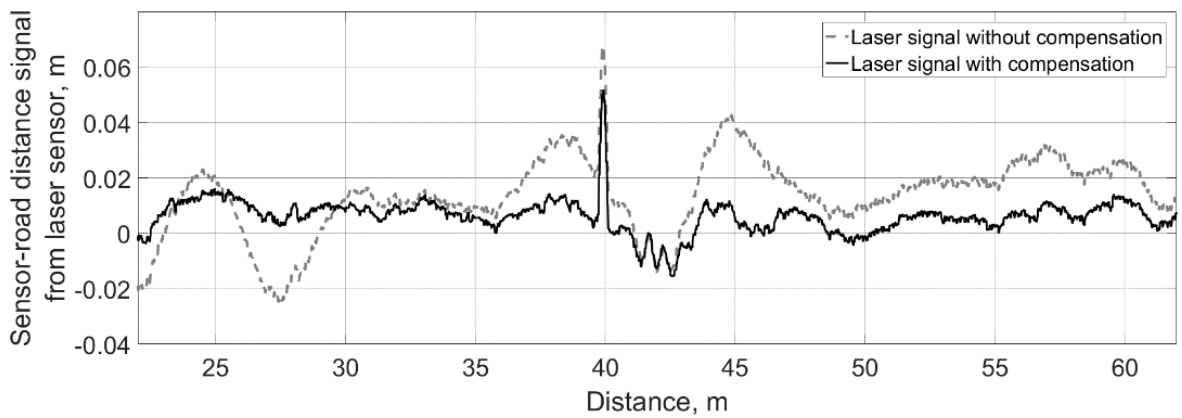

Fig. S.3.1. The road profile estimation using laser sensor, soft damping case 


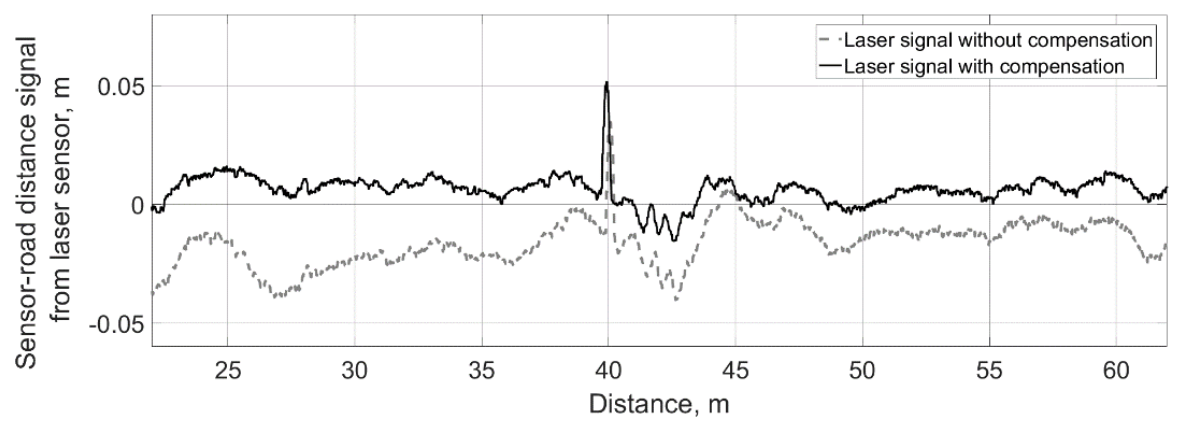

Fig. S.3.2. The road profile estimation using laser sensor, stiff damping case

The curves after the compensation include additional road profile jumps; it is difficult to assess them, because the road surface was not ideally even during the tests and the movement of the vehicle was not absolutely constant.

In Fig. S.3.1 above, it can be observed that when the shock absorbers are set for the minimum damping, considerably more intensive vibrations of the sprung mass appear when the vehicle drives down from an obstacle; however, the compensatory algorithm performs its function - minimization of vibrations.

The theoretical research confirmed that the Algorithm 1 (that operates according to the previously set heights of the road irregularities) operates in the most appropriate way. An analysis of the results of the experimental and theoretical research was carried out upon striving to assess the advantages of the Algorithm 1. The results of control of damping elements by the Algorithm 1 were compared to control by "Skyhook" principle and a case with a passive suspension. In a real system, signals from the laser sensor are processed in the real time according to the above-described compensation algorithm and used for controlling semi-active suspensions.

In Fig. S.3.3 below, a vertical displacement of the vehicle body is shown. The diagram reflects the advantages of the Algorithm 1: on movement of the vehicle over a road irregularity, no upward displacement takes place, whereas a downward displacement is less than $0.02 \mathrm{~m}$.

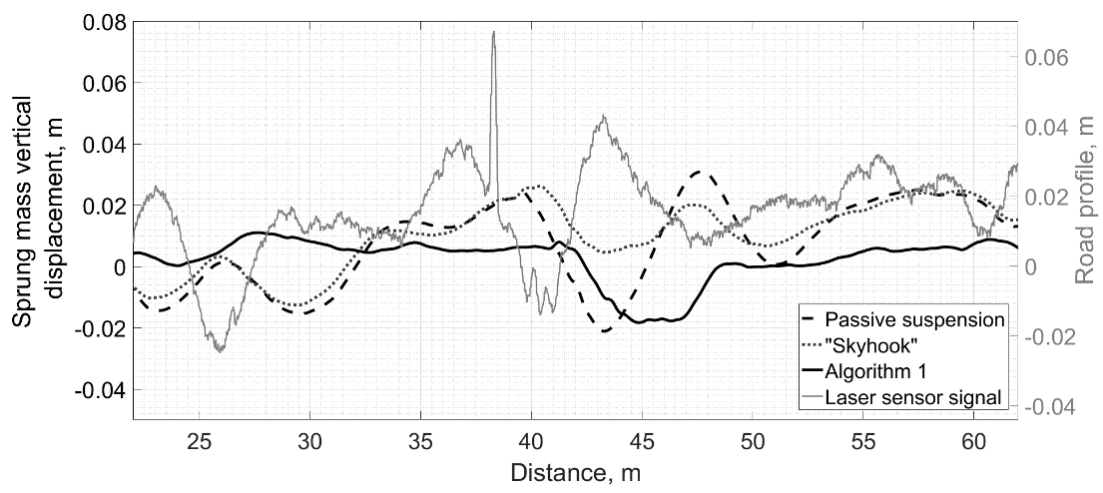

Fig. S.3.3. Sprung mass vertical displacement with passive, "Skyhook" control and novel algorithm called Algorithm 1 at $30 \mathrm{~km} / \mathrm{h}$ velocity 
If "Skyhook" principle is applied, the amplitude of vertical displacement of the sprung mass of the moving vehicle is not high $(0.035 \mathrm{~m})$; however, the vibrations last longer. Movement of a vehicle with a passive suspension is distinguished for most abundant imperfections, because the amplitude of vibrations is high - it exceeds $0.04 \mathrm{~m}$ and the vibrations last longer.

In case of the Algorithm 1, the pitch angle varies between $-0.9^{\circ}$ and $0.9^{\circ}$ (the minus reflects the clockwise rotation on the vehicle in the centre of gravity) after passing the road irregularity (Fig. S.3.4). In case of "Skyhook", the said angle varies between $-0.9^{\circ}$ and $1.6^{\circ}$; in case of a passive suspension - between $1.7^{\circ}$ and $2.5^{\circ}$. The sprung mass pitch angle is an important parameter that affects the comfortability of travelling (the driver and the passengers do not feel the body vibrations) and its safety (after passing a road irregularity, a contact of the wheel with the road surface is ensured to the maximum possible extent).

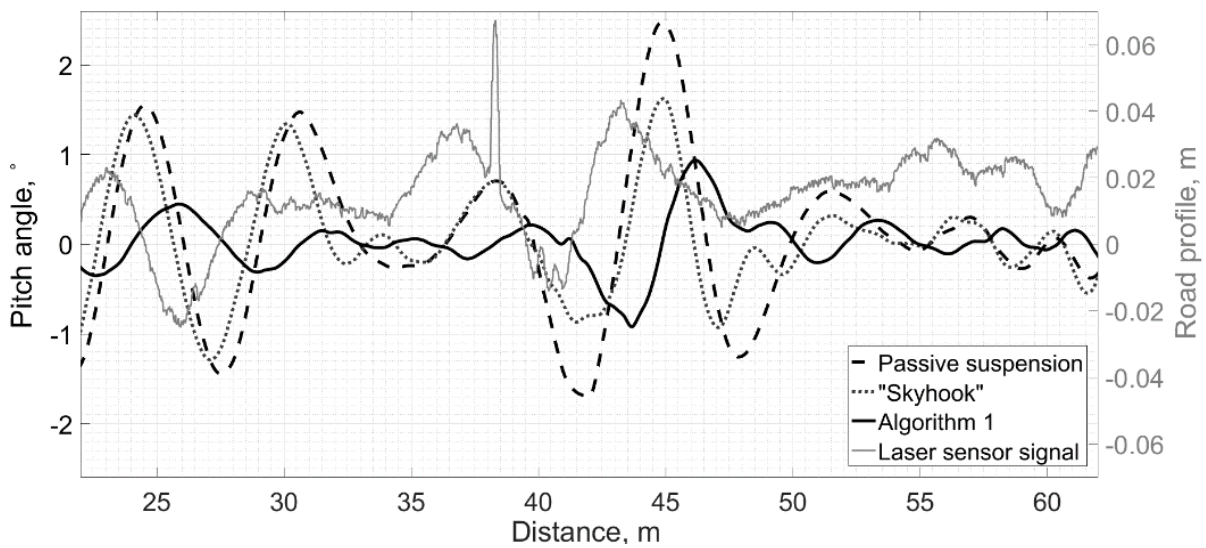

Fig. S.3.4. Pitch with passive, "Skyhook" control and novel algorithm called Algorithm 1 at $30 \mathrm{~km} / \mathrm{h}$ velocity

Reviewing Figs S.3.3 and S.3.4 shows that in case of applying the Algorithm 1, movement of the vehicle is more comfortable, as compared to the passive suspension and "Skyhook" principle, because the displacement of the sprung mass and the pitch angle are less. The experimental research confirms that well-timely altered damping forces of the shock absorber reduce vibrations of the vehicle body on movement of the vehicle over a velocity-reducing hill of sinusoidal shape. 


\section{General conclusion}

1. The created half-car mathematical model with a laser distance sensor enables to explore the dynamics of the vehicle at different velocities on road irregularities of different heights. In addition, the obtained signal of the laser sensor can be used for verification of the algorithms of systems and creation of new systems.

2. In course of the theoretical research, it was found that "Skyhook" semi-active suspension control principle reduces a displacement of the sprung mass by $9 \mathrm{~mm}$, when the vehicle moves over $0.05 \mathrm{~m}$ high velocity-reducing bump of semi-sinusoidal shape with the velocity of $30 \mathrm{~km} / \mathrm{h}$ and the pitch angle decreases by $0.34^{\circ}$ on the average.

3. In course of the experimental research, it was found that a rational point for fixing the laser distance sensor is on the front bumper case in the direction perpendicular to the road surface and should be chosen dependently on the distance between the centre of the front wheel and the front of the vehicle. The distance of the point of fixing the laser sensor from the front axle affects the duration of alterations of the damping forces and the maximum acceleration of the vehicle, because the road surface is measured before the wheel comes down on the road irregularity.

4. The principles of controlling a semi-active suspension with road irregularities identification before the wheel comes down on them enable reducing the pitch angle of the sprung mass and improving the dynamic parameters of the unsprung mass.

5. In course of analysis of the data obtained in an experimental way upon applying the most advantageous control algorithm when the vehicle moves with the velocity of $30 \mathrm{~km} / \mathrm{h}$ over $0.05 \mathrm{~m}$ high road irregularities, it was found that the algorithm reduced the pitch angle (in the limits between $-0.9^{\circ}$ and $0.9^{\circ}$; for "Skyhook" - between $0.9^{\circ}$ and $1.6^{\circ}$; for a passive suspension - between $1.7^{\circ}$ and $25^{\circ}$ ); the vertical displacement size (by $0.02 \mathrm{~m}$ ) and duration; the amplitude of vibrations of unsprung masses (at the frequency of $3 \mathrm{~Hz}$ ).

6. An alteration of the damping forces of semi-active shock absorbers before the wheel comes down on a road irregularity is beneficiary, because the system alters the damping forces before the wheel achieves the obstacle. In such a case, the dynamics of the vehicle are not affected by electronic and mechanical delays that depend on specific shock absorbers. 


\section{Priedai $^{3}$}
A priedas. Programinio paketo Matlab kodas pradinių pusės automobilio modelio duomenų įvesčiai
B priedas. Eksperimentiniuose tyrimuose naudotų jutiklių specifi- kacija
C priedas. Disertacijos autoriaus sąžiningumo deklaracija
D priedas. Bendraautorių sutikimai teikti publikacijose skelbtą me- džiagą disertacijoje
E priedas. Autoriaus mokslinių publikacijų disertacijos tema kopijos

${ }^{3}$ Priedai pateikiami pridètoje kompaktinèje plokštelèje. 


\author{
Vytenis SURBLYS \\ NELYGIA KELIO DANGA VAŽIUOJANČIO \\ LENGVOJO AUTOMOBILIO PUSIAU AKTYVIOS \\ PAKABOS VALDYMO ALGORITMAI \\ Daktaro disertacija \\ Technologijos mokslai, \\ transporto inžinerija (T 003) \\ SEMI-ACTIVE SUSPENSION CONTROL \\ ALGORITHMS OF A CAR MOVING ON \\ ROUGH ROAD PAVEMENT \\ Doctoral Dissertation \\ Technological Sciences, \\ Transport Engineering (T 003)
}

202002 19. 12,5 sp. I. Tiražas 20 egz.

Vilniaus Gedimino technikos universiteto

leidykla „Technika“,

Saulètekio al. 11, 10223 Vilnius,

http://leidykla.vgtu.lt

Spausdino Bl UAB „Baltijos kopija“

Kareivių g. 13B, 09109 Vilnius 